DIANE APARECIDA DOS REIS SILVA FARINA

ESTABELECIMENTO DE STARTUPS: PROPOSTA DE FRAMEWORK CÍCLICO PARA GERAÇÃO E REFINAMENTO DE CONCEITOS E ESTRUTURAÇÃO DA OPERAÇÃO INICIAL DE NEGÓCIOS INOVADORES 
DIANE APARECIDA DOS REIS SILVA FARINA

\title{
ESTABELECIMENTO DE STARTUPS: PROPOSTA DE FRAMEWORK CÍCLICO PARA GERAÇÃO E REFINAMENTO DE CONCEITOS E ESTRUTURAÇÃO DA OPERAÇÃO INICIAL DE NEGÓCIOS INOVADORES
}

\author{
Dissertação apresentada à Escola \\ Politécnica da Universidade de São \\ Paulo para obtenção do título de \\ Mestre em Ciências.
}


DIANE APARECIDA DOS REIS SILVA FARINA

ESTABELECIMENTO DE STARTUPS: PROPOSTA DE FRAMEWORK CÍCLICO PARA GERAÇÃO E REFINAMENTO DE CONCEITOS E ESTRUTURAÇÃO DA OPERAÇÃO INICIAL DE NEGÓCIOS INOVADORES

\author{
Dissertação apresentada à Escola \\ Politécnica da Universidade de São \\ Paulo para obtenção do título de \\ Mestre em Ciências. \\ Área de Concentração: \\ Engenharia de Produção \\ Orientador: \\ Prof. Dr. André Leme Fleury
}


FICHA CATALOGRÁFICA

Farina, Diane Aparecida dos Reis Silva

Estabelecimento de startups: proposta de framework cíclico para geraçăo e refinamento de conceitos e estruturação da operação inicial de negócios inovadores / D. A. R. S. Farina -- Săo Paulo, 2017. $184 \mathrm{p}$.

Dissertação (Mestrado) - Escola Politécnica da Universidade de Săo Paulo. Departamento de Engenharia de Produção.

1.Cadeia de Valor da Inovaçăo 2.Design Thinking 3.Lean Startup 4.Business Model Canvas I.Universidade de Săo Paulo. Escola Politécnica. Departamento de Engenharia de Produçăo II.t. 


\section{AGRADECIMENTOS}

À família na qual nasci e à qual escolhi, aos meus pais, Rosangela e Geson pelo suporte e carinho que me possibilitou alçar voos tão altos, mais altos do que pensei um dia ser capaz. À minha irmã Carine, que com suas graças e casos tornou a minha jornada mais leve e divertida. Ao meu esposo Gabriel, que iniciou esta jornada comigo ainda como namorado e no decorrer desta se tornou meu noivo e hoje esposo, sou grata por sua ajuda e compreensão nos momentos de minha ausência e vezes humor difícil, sou grata por me amar e cuidar de mim.

Ao Prof. Dr. André, por me dar grande suporte em toda esta jornada, sempre me auxiliando e sendo atencioso, sendo o responsável por abrir meus olhos para um universo de possibilidades e até mesmo para o meu próprio potencial, sou grata pela grande oportunidade.

Ainda aos meus amigos por muitas vezes compreenderem a minha ausência e por sempre buscarem um jeito de me incluir mesmo assim, além de que com suas graças tornaram a jornada mais divertida.

Aos especialistas focados em startups participantes, que em sua agenda repleta de compromissos arrumaram um tempinho para responder o questionário de uma mestranda e aceitaram compartilhar seu conhecimento, com a preocupação da compreensão de seu ponto de vista com atenção e sem pedir nada em troca.

Aos empreendedores de startups que mesmo em sua rotina agitada na busca pela sobrevivência de seu negócio conseguiram parar por um instante e responder um questionário para ajudar uma mestranda e futuros empreendedores pelo simples desejo de ver os resultados desta pesquisa.

A CAPES pelo apoio em minha pesquisa.

Ao universo pela possibilidade e abertura de horizontes. 


\section{RESUMO}

Atualmente as organizações enfrentam grandes desafios como por exemplo a necessidade de reduzir o ciclo de vida de produtos e serviços, enfrentar exigências de qualidade superiores, menores tempo de desenvolvimento e menores custos de produção, devendo buscar a excelência produtiva mas, contraditoriamente também sendo cobradas pelo desenvolvimento de inovações e pela busca de maior agilidade.

Neste cenário verifica-se o aumento na importância das startups, organizações que exploram novas oportunidades no mercado e que apresentam grande potencial para geração de inovações radicais. Apesar do aumento da sua relevância, ainda existem poucos modelos elaborados e validados, capazes de auxiliar estas organizações em seu processo inicial de estruturação de operação. Como consequência, atualmente as startups podem adotar técnicas inadequadas à sua realidade, reconhecidamente burocráticas, inflexíveis e pouco inovadoras.

Buscando reduzir esta lacuna de conhecimento este estudo propõe um Framework Cíclico que visa contribuir com as startups em seu processo de geração e refinamento de conceitos e na estruturação inicial da sua operação, tendo como objetivo facilitar 0 atingimento do sucesso. Para o seu desenvolvimento inicialmente foi realizada ampla revisão bibliográfica, resultando numa primeira versão do Framework. Esta versão foi utilizada para a realização de dois estudos de caso que, em conjunto com a qualificação, resultou em alterações no seu layout porém manteve suas características essenciais. Uma segunda versão do Framework Cíclico foi avaliada em um painel que contou com a participação de 8 especialistas em startups, profissionais conceituados cujas observações foram analisadas utilizando de Análise Qualitativa, resultando numa mudança de etapa no Framework, incorporando o Canvas do Value Proposition Design e algumas contribuições no detalhamento das etapas.

Com a terceira versão do Framework estruturada foi realizada uma survey que contou com a participação de 88 empreendedores de startups consideradas de sucesso. Para isto, de forma a estabelecer a amostra da pesquisa foram selecionadas startups com existência de mais de um ano, já aceleradas ou em processo de aceleração em aceleradoras brasileiras. Os resultados obtidos foram trabalhados com aplicação de Análise Qualitativa e Análise Fatorial e, como resultados, ocorreu a mudança de posicionamento de uma etapa, além da contribuições que destacam alguns pontos de atenção no desenvolvimento das diferentes etapas. Assim, foi obtida a versão final do Framework Cíclico, correspondendo ao objetivo proposto para este estudo, auxiliar na geração e refinamento de conceitos e estruturação da operação inicial de negócios inovadores.

Palavras-chave: Cadeia de Valor da Inovação; Design Thinking; Lean Startup; Business Model Canvas. 


\section{ABSTRACT}

Currently organizations face major challenges such as the need to reduce product and service life cycles, to obtain higher quality standards and lower production costs, aiming to obtain excellence in production but, contradictorily, aiming to develop significant innovations and to foster more agility.

In this scenario it is possible to observe the growing importance of startups, emerging companies that explore new market opportunities and have big potential for the generation of radical innovations. Despite the increase of their relevance, until now there are few structured and validated models, capable of contributing with these organizations in their initial phases. As a consequence, currently startups can only adopt techniques that are inadequate to their reality since they are bureaucratic, inflexible and little innovative.

Aiming to reduce this gap of knowledge, this research proposes a Cyclic Framework that aims to contribute with the startups in their process of generation and refinement of concepts and in the initial structuration of its operation, in order to facilitate the achievement of success. For the development of the first version an extensive literature review was performed. This version of the Framework was applied in two case studies that, in conjunction with the qualification, resulted in changes in the layout of the Framework but maintained its essencial characteristics. This second version of the Cyclic Framework was evaluated in a panel that counted with the participation of 8 specialists in startups, recognized professionals whose observations have been analyzed with the application of qualitative analysis. As a result a stage changed in Framework, including Canvas of Value Proposition Design and some other contributions were incorporated into the detailed steps of the Framework.

Considering this third version of the Framework structured and validated, a final survey was performed and 88 entrepreneurs of startups participated. The sample for this research was selected at startups with existence of more than one year, that are already accelerated or in acceleration process at Brazilian accelerators. The obtained results were analyzed with the application of Qualitative Analysis and quantitative Factor Analysis and, as results, there was a change in the position of a step and the improvement of points of attention in the development of different steps. As a result the final version of the Cyclic Framework was developed and the main objective of this study was obtained, the development of a tool to contribute in the generation and improvement of concepts and structuring in the initial operation of innovative businesses.

Keywords: Innovation Value Chain; Design Thinking; Lean Startup; Business Model Canvas. 


\section{LISTA DE FIGURAS}

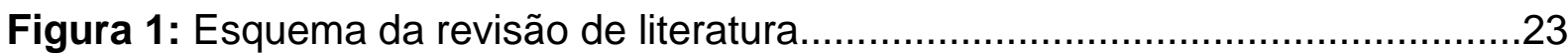

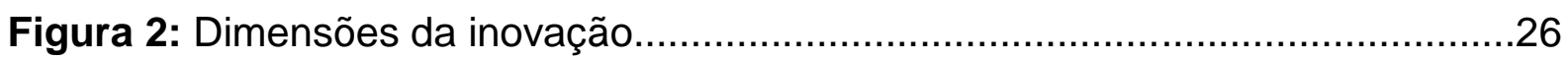

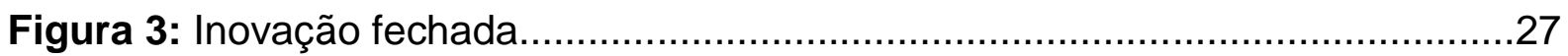

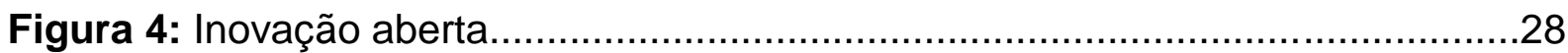

Figura 5: Processo com uma interrupção: Espera por Mercado............................33

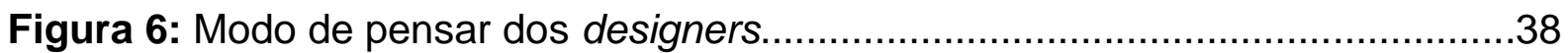

Figura 7: Etapas do processo de Design Thinking............................................

Figura 8: Fluxo das etapas do processo de Design Thinking ..................................46

Figura 9: Paralelo entre o Desenvolvimento de Produto e Consumidor....................57

Figura 10: Detalhamento do Desenvolvimento do Consumidor..............................57

Figura 11: Looping de aprendizado do Lean Startup.........................................62

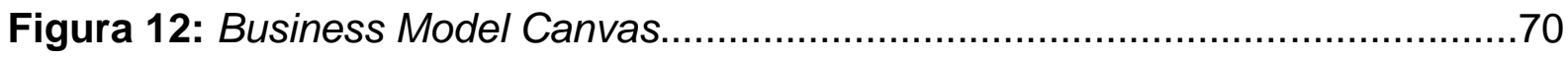

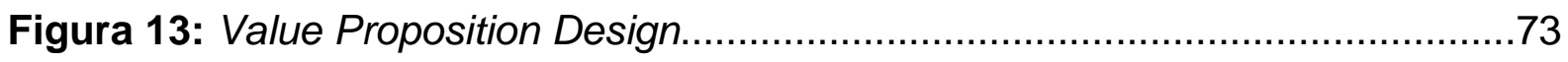

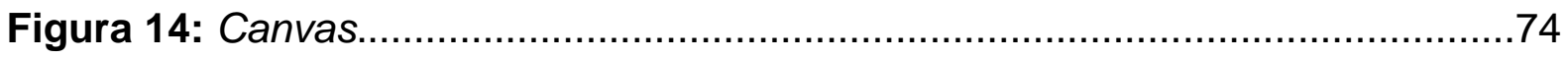

Figura 15: Primeira versão do Framework Cíclico, baseado na revisão de literatura e

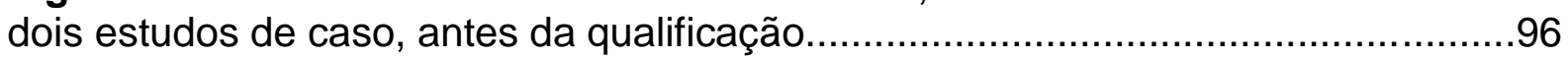

Figura 16: Segunda versão parcial do Framework Cíclico, baseado na revisão de literatura e dois estudos de caso, após qualificação............................................100

Figura 17: Segunda versão final do Framework Cíclico, baseado na revisão de literatura e dois estudos de caso, após qualificação..............................................101

Figura 18: Terceira Versão do Framework Cíclico com base no painel de especialistas em startups. 111

Figura 19: Quarta e final versão do Framework Cíclico. 142 


\section{LISTA DE GRÁFICOS}

Gráfico 1: Evolução do índice Nasdaq Composite...............................................17

Gráfico 2: Escolaridade dos empreendedores de startups de sucesso..................115

Gráfico 3: Scree Plot das etapas do Framework Cíclico para os empreendedores de startups.

Gráfico 4: Scree Plot das etapas do Framework Cíclico para os empreendedores de startups, após a retiradas de variáveis.

Gráfico 5: Base de dados posicionando os fatores conforme a carga fatorial nos componentes das etapas do Framework Cíclico para os empreendedores de startups. 


\section{LISTA DE QUADROS}

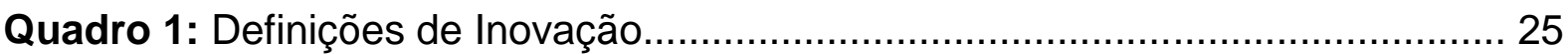

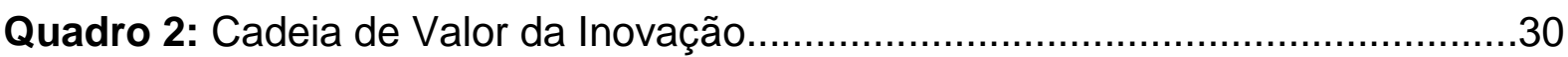

Quadro 3: Definição de Modelos de Negócio.............................................................65 


\section{LISTA DE TABELAS}

Tabela 1: Linha do tempo de artigos sobre empreendedorismo em economias emergentes.

Tabela 2: Uso e recomendação das etapas do Framework Cíclico para os empreendedores de startups.

Tabela 3: Estatística Descritiva para as etapas do Framework Cíclico em relação às respostas dos empreendedores de startups.

Tabela 4: Interpretação do coeficiente de correlação.

Tabela 5: Matriz de correlação das etapas propostas pelo Framework Cíclico em relação às respostas dos empreendedores de startups.

Tabela 6: Teste de Esfericidade de Barlett e Kaiser Meyer Olkinde (KMO) em relação às respostas dos empreendedores de startups. 122

Tabela 7: Explicação da variância das etapas do Framework Cíclico em relação às respostas dos empreendedores de startups. 123

Tabela 8: Comunalidade das etapas do Framework Cíclico em relação às respostas dos empreendedores de startups.

Tabela 9: Teste de Esfericidade de Barlett e Kaiser Meyer Olkinde (KMO) em relação às respostas dos empreendedores de startups, após a retirada de variáveis. 125

Tabela 10: Explicação da variância das etapas do Framework Cíclico em relação às respostas dos empreendedores de startups, após a retirada de variáveis. 125

Tabela 11: Comunalidade das etapas do Framework Cíclico em relação às respostas dos empreendedores de startups, após a retirada de variáveis. 126

Tabela 12: Matriz Componente das etapas do Framework Cíclico em relação às respostas dos empreendedores de startups.

Tabela 13: Matriz Componente com rotação das etapas do Framework Cíclico em relação às respostas dos empreendedores de startups. 127

Tabela 14: Matriz Ortogonal das etapas do Framework Cíclico em relação às respostas dos empreendedores de startups 


\section{SUMÁRIO}

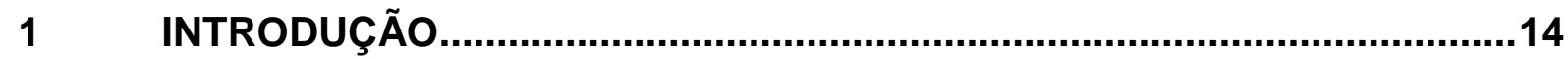

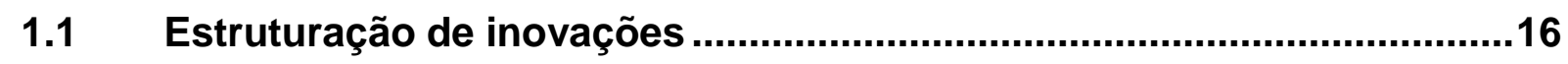

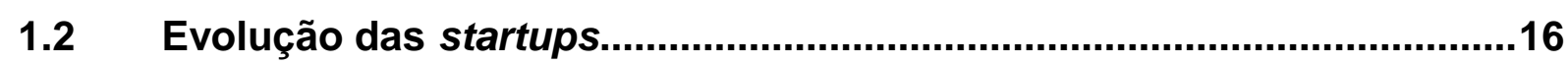

1.3 Questões motivadoras desta pesquisa ................................................18

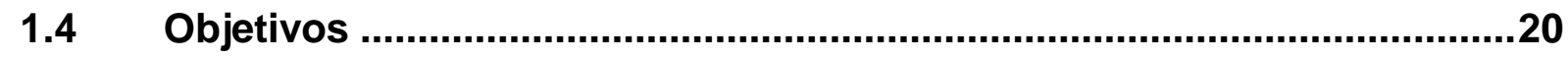

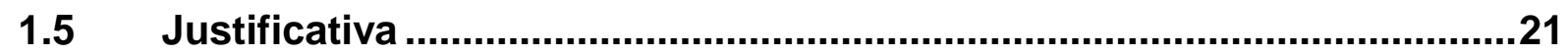

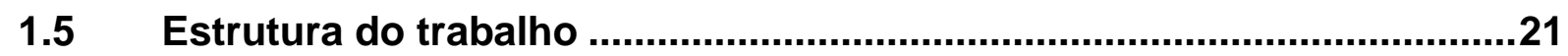

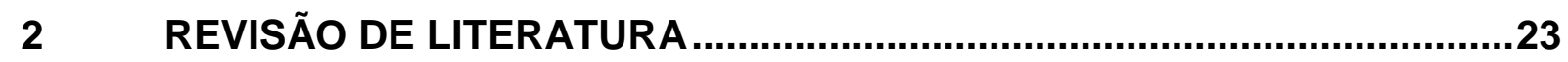

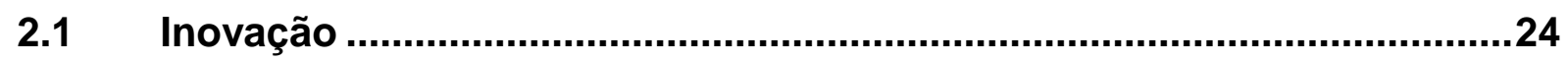

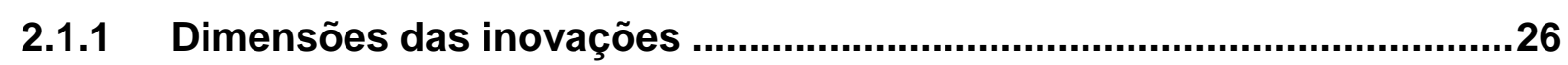

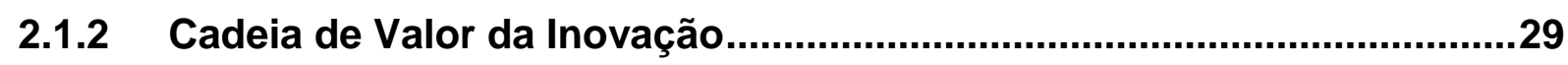

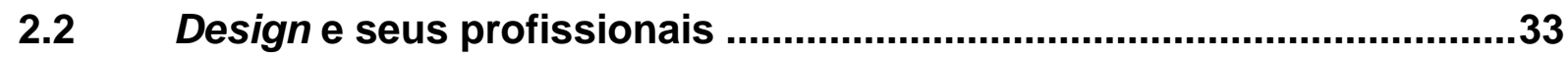

2.2.1 Problematização da área de Design ........................................................35

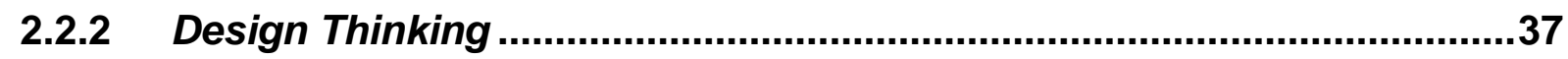

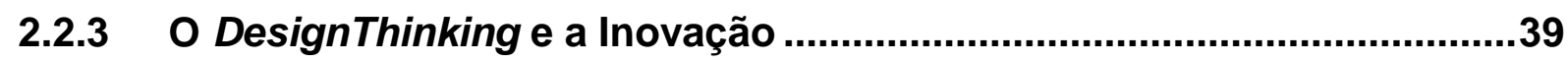

2.2.4 As fases do Design Thinking …....................................................

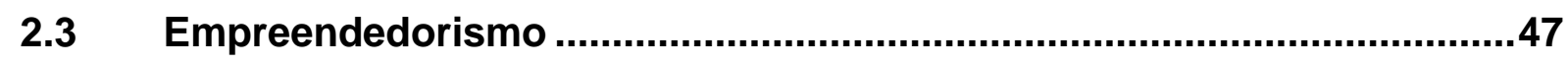

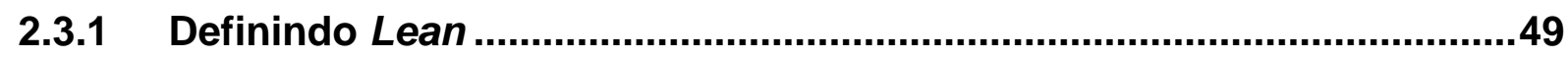

2.3.2 Definindo Startup e termos associados .................................................49

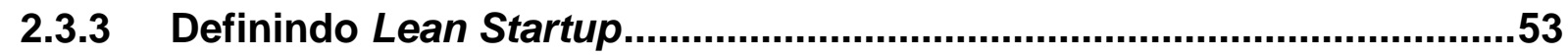

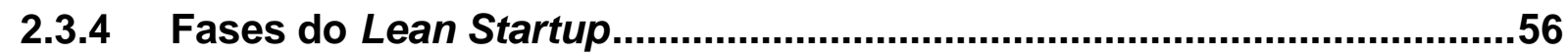

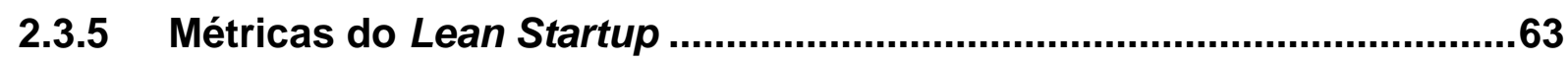

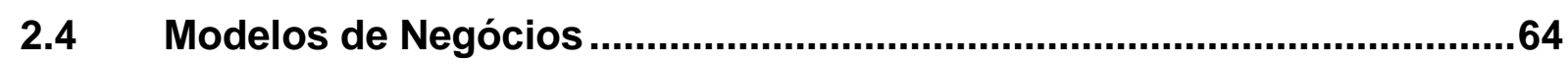

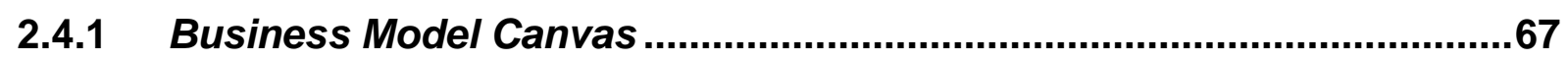

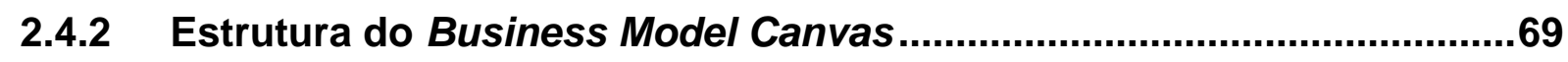

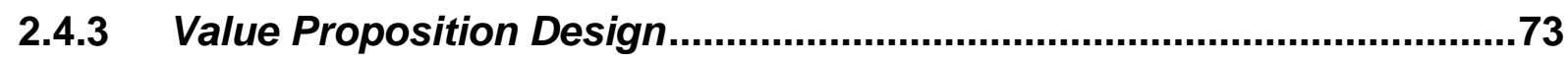

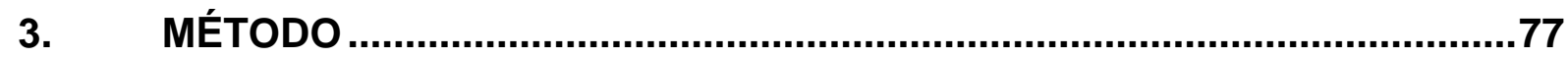

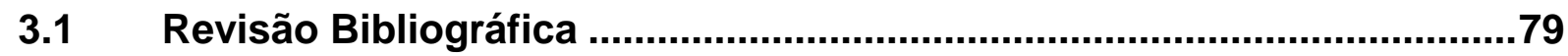

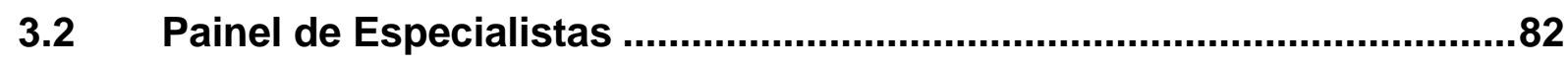

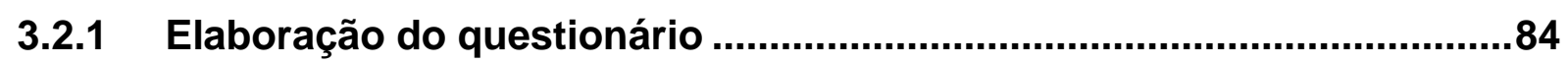

3.2.2 Testes-piloto e ajustes do questionário .................................................86

3.2.3 Seleção dos respondentes do Painel de Especialistas e envio do questionário. 


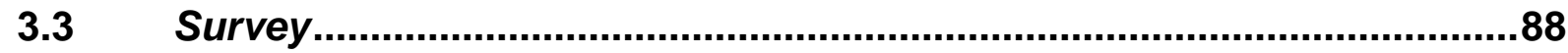

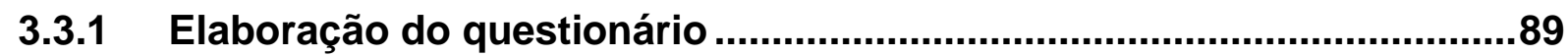

3.3.2 Testes-piloto e ajustes do questionário ................................................90

3.3.3 Seleção dos respondentes da Survey e envio do questionário.............90

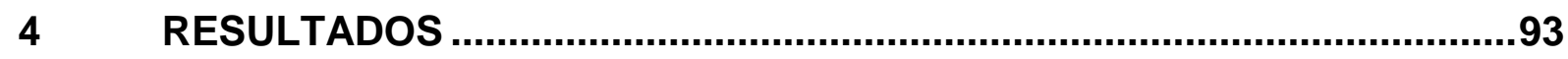

4.1 Revisão Bibliográfica e elaboração da primeira versão do Framework

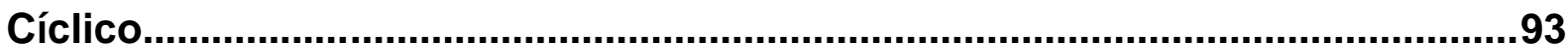

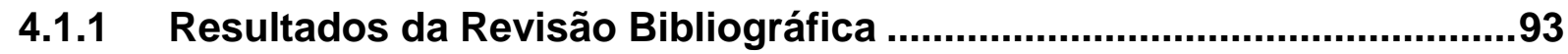

4.1.2 Primeira versão do Framework Cíclico ….............................................95

4.2 Revisões recomendadas na Qualificação e segunda versão do

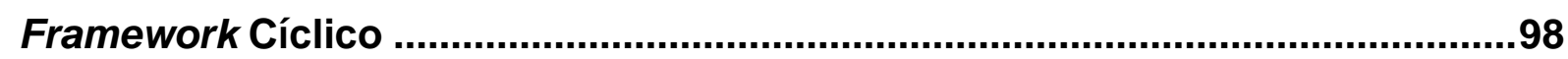

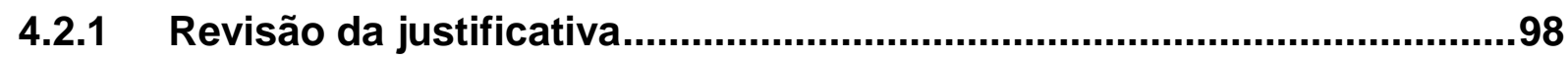

4.2.2 Revisão do nome e layout da primeira versão do Framework Cíclico e segunda versão do Framework Cíclico. .99

4.3 Realização do Painel de Especialistas e terceira versão do Framework Cíclico 102

4.3.1 Análise dos resultados do Painel de Especialistas ............................102

4.3.2 Terceira versão do Framework Cíclico.................................................110

4.4 Survey junto aos empreendedores de Startups....................................114

4.4.1 Análise dos resultados da Survey.......................................................114

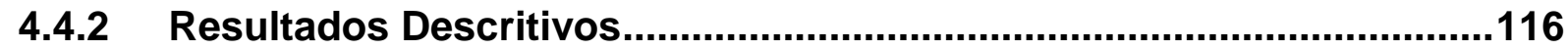

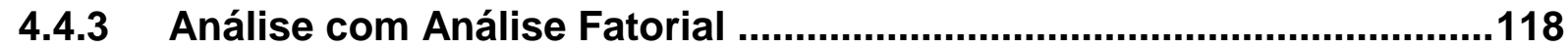

4.4.4 Análise Qualitativa dos Resultados Obtidos .......................................128

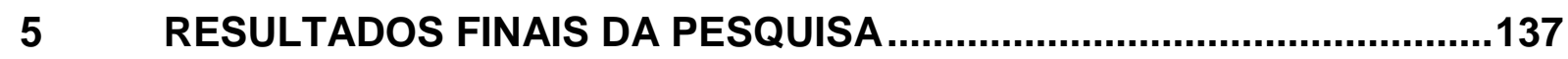

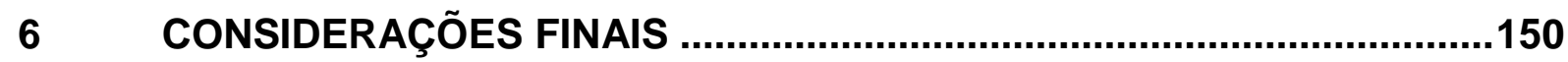

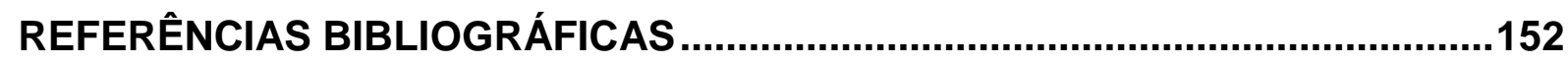

ANEXO 1 - Questionário de testes antes da Qualificação .................................161

ANEXO 2 - Questionário dos Especialistas em Startups...................................167

ANEXO 3 - Questionário dos Empreendedores de Startups ..............................175 


\section{INTRODUÇÃO}

De acordo com Kotler (2006), Carvalho (2009) e Arbix (2010), inovação é a capacidade de construir algo novo, comercializável, em sintonia com os processos produtivos organizacionais. Tem origem na identificação de oportunidades em mercados novos ou existentes, sendo consideradas como invenções de sucesso, que alcançam o mercado, entregando valor igual ou superior à expectativa inicial do consumidor.

O processo de desenvolvimento de inovações pode ser classificado como fechado ou aberto. O processo fechado é caracterizado pelo foco nos processos de pesquisa e desenvolvimento internos da organização, o que eventualmente pode ocasionar perda de oportunidades, pois este processo pode demandar conhecimentos e habilidades que a organização não detém internamente (CHESBROUGH, 2003). Já o processo de desenvolvimento de inovações aberto, segundo Chesbrough (2003), é marcado pela porosidade entre o ambiente interno e o ambiente externo da organização durante o processo de desenvolvimento de produtos e de serviços, permitindo que a empresa beneficie-se de conhecimentos e habilidades disponíveis no ambiente externo (inbound), eventualmente também podendo aprimorar estes conhecimentos e habilidades e disponibilizá-los externamente para o mercado (outbound). Segundo Biancolino, Maccari e Pereira (2013), as inovações podem variar quanto ao grau de inovatividade e impacto, podendo ser classificadas como inovações radicais ou incrementais. Ainda de acordo com os autores, inovações radicais geram mudanças significativas na forma como usamos ou vemos as coisas; por sua vez, inovações incrementais geram mudanças menores nos aspectos já existentes em produtos e serviços.

Este estudo tem interesse nas inovações radicais e, neste contexto, vale observar que nas últimas décadas uma importante parcela destas inovações foram geradas por startups, organizações de pequeno porte usualmente originárias do desejo por empreender, por fazer diferente mesmo que com recursos limitados (LEUNG et al., 2006). Neste tipo de organização os empreendedores são completamente responsáveis pelo negócio e têm total autonomia para inovar e fazer diferente, sem ter de enfrentar longos processos burocráticos para viabilizar seus projetos (LEUNG et al., 2006). Edison (2015) menciona que a geração de inovações vem ocorrendo predominantemente nas startups, já que grandes organizações tem 
de dispender esforço significativo para enfrentar desafios eventualmente contraditórios relacionados com a aquisição de excelência na produção e o desenvolvimento de inovações.

Segundo Nirwan e Dhewanto (2015), o empreendedorismo torna-se cada vez mais relevante no mundo, tanto em países desenvolvidos como em países ainda em desenvolvimento, gerando um número significativo de novos negócios. Os autores também mencionam que espera-se que o empreendedorismo cresça de forma exponencial ao longo dos próximos anos, mesmo considerando a alta taxa de mortalidade deste tipo de empresa. Para Risku e Abrahamsson (2015), as startups são importantes motores na economia atual e nem mesmo as altas taxas de falhas tem desencorajado empreendedores, comunidades e universidades de investirem em ecossistemas para a criação e o estabelecimento de startups.

Porém, mesmo com toda a relevância das startups e seu potencial impacto econômico, ainda existe pouca pesquisa com foco em aprimorar o seu processo de desenvolvimento, em especial a geração de ideias e na transformação destas ideias em operações eficientes; neste sentido, encontra-se apenas estudos que buscam endereçar as principais características das falhas das startups (GIARDINO; WANG; ABRAHAMSSON, 2014; RISKU; ABRAHAMSSON, 2015). Segundo Giardino, Wang e Abrahamsson (2014), as startups detém recursos financeiros e de tempo extremamente escassos e apenas uma falha em seu projeto de desenvolvimento pode eliminá-las, fortalecendo a percepção de que estes empreendimentos necessitam de mais conhecimentos e práticas efetivas, capazes de contribuir decisivamente no momento em que estas encaram seus maiores desafios.

Esta pesquisa tem como foco contribuir com o processo de estruturação de startups e, para tal, apresenta um Framework Cíclico capaz de auxiliar no processo de geração e refinamento de conceitos e na estruturação inicial da operação das startups. A pesquisa se justifica pois num contexto em que as inovações tornam-se cada vez mais centrais para as organizações, os resultados obtidos pelas startups vêm despertando a atenção das grandes corporações, fato que pode ser comprovado com a verificação do número crescente de grandes organizações que criaram programas de identificação, seleção e apoio às startups, incluindo desde incentivos financeiros até oportunidades para que estes novos negócios façam parte da sua rede de parceiros. Como exemplos de corporações que vem aderindo a 
estas novas políticas no Brasil temos grandes nomes como Braskem, Bradesco, Telefônica e Natura (TAMAMAR; JAKITAS, 2015).

\subsection{Estruturação de inovações}

Para compreender como potencializar o desenvolvimento de inovações radicais tendo em vista a geração e refinamento de conceitos e a estruturação inicial da operação de novas startups, este estudo adota como referencial orientador a teoria da Cadeia de Valor da Inovação, caracterizada por Hansen e Birkinshaw (2007) enquanto uma lista de questionamentos que busca auxiliar as organizações na resolução das principais dificuldades enfrentadas para inovar. No contexto desta pesquisa a abordagem foi selecionada por sua comprovada efetividade para inovar e por propor fases relevantes para tal. Neste estudo o modelo original da Cadeia de Valor da Inovação será incorporado enquanto guia de fases a serem consideradas, além de ter o seu conteúdo adaptado conforme o contexto específico das startups. Esta adaptação é justificada por Salerno et al. (2015), que consideram o modelo da Cadeia de Valor da Inovação em sua forma original como não sendo ideal para pequenas organizações.

\subsection{Evolução das startups}

Em função de sua capacidade de gerar inovações radicais este projeto de pesquisa tem como foco as startups. Para Hartmann (2013) e Kiss, Danis e Cavusgil (2012), startups são um movimento recente e por este motivo ainda demandam extensa pesquisa. Segundo Gitahy (2010), sua realidade específica apenas começou a ser trabalhada após o período da "bolha da internet", compreendido entre os anos de 1996 e 2001, quando o termo startup foi amplamente popularizado nos Estados Unidos.

De acordo com Rizério (2013), um momento importante na história das startups é o "estouro da bolha da internet", evento ocorrido em 10 de março de 2000 e que erodiu completamente o índice Nasdaq (bolsa de valores norte americana com foco principal em negócios tecnológicos). O Gráfico 1 apresenta a evolução deste índice, onde o eixo horizontal representa a evolução do tempo e o eixo vertical apresenta o volume de negócios registrados. O início da Bolha após 1995 reflete o aumento considerável no valor das ações das organizações "ponto.com" (virtuais), 
que elevou fortemente o índice graças a uma confiança excessiva em lucros futuros, o que aumentou ainda mais o capital disponível, baixou a taxa de juros e gerou maior dificuldade na avaliação do valor correto destas empresas. Devido à corrupção corporativa verificada em grandes empresas envolvendo a maquiagem de balanços na virada do milênio (2000) ocorreu o "estouro da bolha", ou seja, a queda expressiva no valor das ações das organizações "ponto.com" e consequentemente do índice da bolsa (RIZÉRIO, 2013).

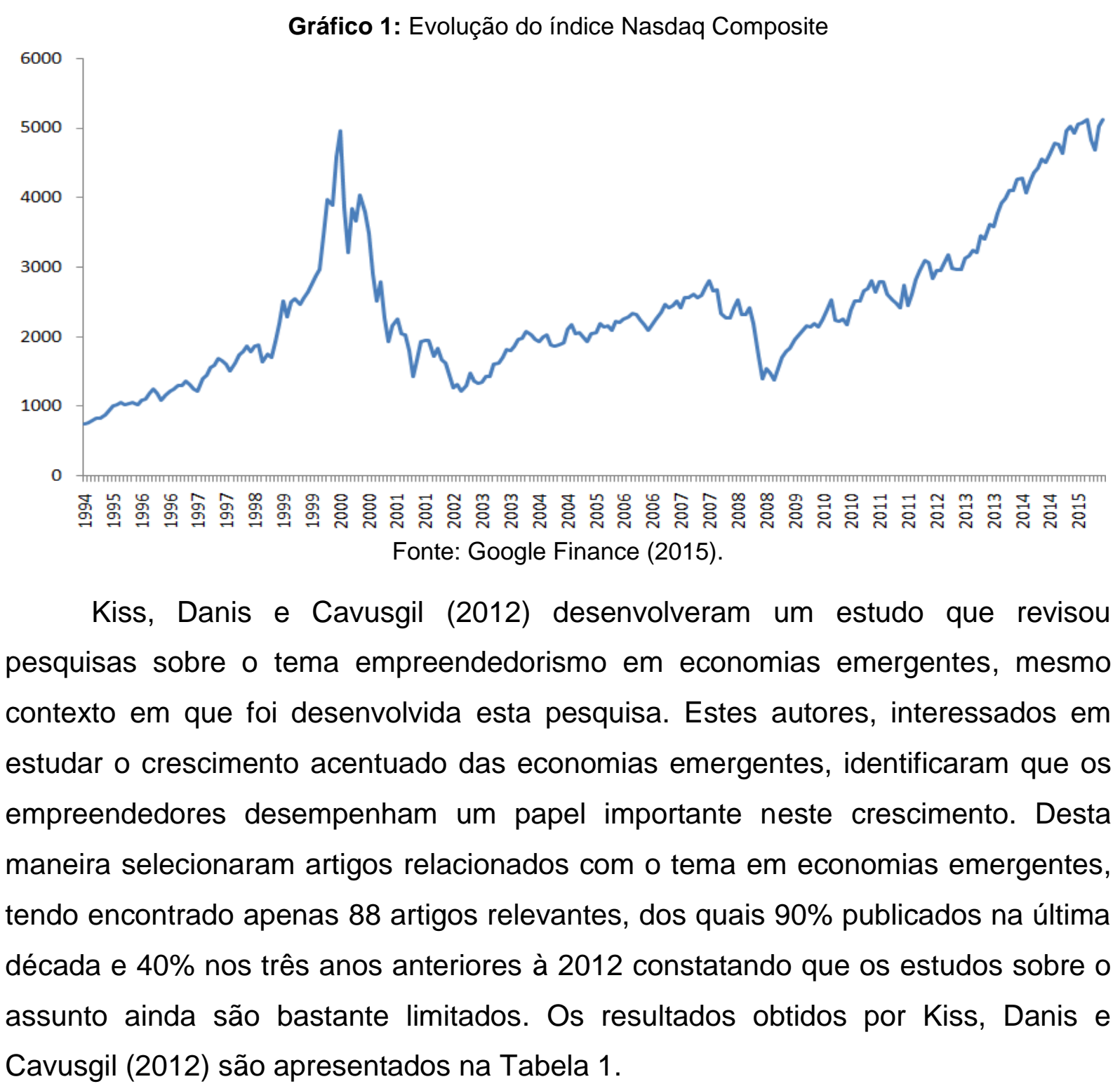


Tabela 1: Linha do tempo de artigos sobre empreendedorismo em economias emergentes

\begin{tabular}{|c|c|c|c|c|c|c|c|c|c|c|c|c|c|c|}
\hline \multirow[b]{2}{*}{ Period } & \multicolumn{8}{|c|}{ Entrepreneurship journals } & \multicolumn{4}{|c|}{ IB journals } & \multirow[b]{2}{*}{ Total } & \multirow[b]{2}{*}{$\%$ by year } \\
\hline & ETP & JBV & JDE & JIE & Tech & ISB] & JSBM & SBE & IBR & JIBS & JWB & MIR & & \\
\hline Pre-2000 & 2 & 2 & & & 1 & 1 & 2 & 1 & & & & & 9 & $10.3 \%$ \\
\hline 2000-2001 & 1 & & 1 & & & 1 & & 2 & & 1 & 1 & & 7 & $8.0 \%$ \\
\hline $2002-2003$ & 1 & 2 & 2 & & & 1 & 1 & 4 & & & & & 11 & $12.6 \%$ \\
\hline 2004-2005 & 1 & 1 & 2 & 2 & 1 & & & 1 & 1 & & 1 & & 10 & $11.5 \%$ \\
\hline 2006-2007 & 1 & & 3 & & & & & 5 & & 4 & 1 & & 14 & $16.1 \%$ \\
\hline 2008-2009 & 5 & 1 & 2 & 8 & & & 1 & 1 & 2 & 2 & & 1 & 23 & $26.4 \%$ \\
\hline 2010 & 3 & 2 & 2 & 2 & & & & & 1 & 2 & 2 & & 14 & $14.9 \%$ \\
\hline Total & 14 & 8 & 12 & 12 & 2 & 3 & 4 & 14 & 4 & 9 & 5 & 1 & 88 & $100 \%$ \\
\hline \% by journal & $16.0 \%$ & $9.1 \%$ & $13.6 \%$ & $13.6 \%$ & $2.3 \%$ & $3.4 \%$ & $4.5 \%$ & $16 \%$ & $4.5 \%$ & $10.2 \%$ & $5.7 \%$ & $1.1 \%$ & $100 \%$ & \\
\hline \% by category & $78.2 \%$ & & & & & & & & $21.8 \%$ & & & & $100 \%$ & \\
\hline
\end{tabular}

Fonte: KISS, A. N.; DANIS, W. M.; CAVUSGIL, S. T. (2012, p. 270).

Onde temos como os periódicos indicados pelos autores os seguintes:

ETP: Entrepreneurship Theoryand Practice

JBV: Journal of Business Venturing

JDE: Journal of Differential Equations

JIE: Journal of Industrial Ecology

Tech: Technovation

ISBJ: International Small Business Journal

JSBM: Journal of Small Business Management

SBE: Small Business Economics

IBR: International Business Review

JIBS: Journal of International Business Studies

JWB: Journal of World Business

MIR: Management International Review

Kiss, Danis e Cavusgil (2012) também mencionam que ao longo de sua pesquisa identificaram artigos relacionados com empreendedorismo em publicações das áreas de estratégia e gestão, evidenciando a importância dos empreendedores para o crescimento das economias emergentes. Os autores apontam fatores como orientação, acesso aos recursos e política de ambiente favorável como importantes para o sucesso dos empreendedores, assim como o crescimento dos fundos de Venture Capitals (KISS; DANIS; CAVUSGIL, 2012). Os autores também destacam o forte crescimento nos estudos relacionados com 0 empreendedorismo em economias emergentes, foco principal desta pesquisa.

\subsection{Questões motivadoras desta pesquisa}

Apesar de sua relevância na geração de inovações radicais as startups enfrentam grandes dificuldades no contexto brasileiro. Segundo Arruda et al. (2013), $25 \%$ são descontinuadas com menos de 1 ano, $50 \%$ com menos de 4 anos e $75 \%$ com menos de 13 anos de idade, sendo poucas as pesquisas que identificam e analisam sua realidade, mesmo com a sua evidente contribuição para o desenvolvimento tecnológico, econômico e social de um país. Salerno et al. (2015) 
defendem que os estudos não devem ser restritos apenas às grandes organizações, sendo necessários estudos que foquem nas pequenas organizações ou mesmo em unidades singulares de corporações, que muitas vezes geram inovações radicais em ambientes de alta incerteza e complexidade, usualmente fruto da emergência de tecnologias disruptivas e do acesso a novos mercados. McVea (2009) considera que cada vez mais os empreendedores operam na fronteira do conhecimento humano, costumeiramente sendo os pioneiros na evolução destes conhecimentos, transformando-os em novos serviços e produtos.

Neste contexto de necessidade de maior exploração do empreendedorismo em economias emergentes e frente às dificuldades encontradas pelos empreendedores para conseguir evoluir seus negócios, este estudo considera relevante compreender melhor as abordagens aplicadas pelas startups de sucesso, definindo como startups de sucesso aquelas que possuem mais de um ano de existência e encontram-se em processo de aceleração ou concluíram recentemente este processo. Busca-se com esta compreensão identificar padrões, capazes de viabilizar a construção de um Framework Cíclico, que funcione como um guia para a geração e refinamento de conceitos e a estruturação inicial da operação de novas startups.

Para atingir estes objetivos o desenvolvimento deste estudo procura responder às seguintes questões:

1. Existem fases e etapas indicadas pela literatura para a geração e refinamento de conceitos e para a estruturação da operação inicial de novas startups? Se sim, quais são?

2. Considerando a opinião de especialistas e empreendedores de startups, quais das etapas propostas pelo Framework Cíclico são efetivamente relevantes na constituição de uma startup de sucesso? E quais são consideradas menos relevantes?

3. Qual o perfil dos empreendedores das startups de sucesso abordados por esta pesquisa?

4. Os empreendedores das startups de sucesso efetivamente utilizaram as etapas identificadas anteriormente para buscar o sucesso das suas startups?

5. A maioria destas etapas são recomendadas por estes empreendedores e pelos especialistas para a constituição de novas startups de sucesso? 
6. Qual a distribuição ideal de etapas para cada fase do Framework Cíclico?

\subsection{Objetivos}

O principal objetivo deste estudo é identificar e priorizar as principais práticas empregadas por startups de sucesso na estruturação da operação de seus negócios, buscando viabilizar a sua replicação e, assim, garantir o aumento na geração de inovações radicais e vida mais longa para as novas startups. Para isto será elaborado, com base na teoria e validação na prática, um Framework Cíclico que representa todas as etapas efetivamente consideradas como recomendadas e relevantes, sendo empregadas por empreendedores de startups de sucesso pensando no processo de geração e refinamento de conceitos e na estruturação inicial de sua operação.

Desta maneira, os objetivos específicos desta pesquisa são:

1 - Estruturar um Framework Cíclico a partir da revisão de literatura sobre inovação e temas relacionados, capaz de orientar empreendedores no processo de estruturação das suas startups.

2 - Aprimorar este Framework Cíclico a partir das considerações obtidas em dinâmicas realizadas em um painel de especialistas.

3 - Analisar quais práticas deste Framework Cíclico são recomendadas, relevantes e efetivamente foram utilizadas por empreendedores de sucesso ao longo do processo de estruturação de suas startups.

4 - Validar um conjunto de melhores práticas, capazes de serem seguidas por empreendedores durante o processo de estabelecimento da operação de suas startups.

Desta maneira, este projeto de pesquisa busca compreender quais as melhores práticas utilizadas na estruturação de startups inovadoras e analisar em profundidade como estas práticas foram efetivamente aplicadas ao longo do desenvolvimento de startups de sucesso. Para isto, primeiramente foi realizada ampla revisão bibliográfica, originando uma primeira versão do Framework Cíclico; este então foi analisado considerando dois estudos de caso e apresentado à banca de qualificação, resultando então na sua segunda versão. A seguir o Framework foi apresentado em um painel de especialistas, que contou com a participação de 8 profissionais ligados às startups, resultando na construção de uma terceira versão 
deste referencial. Esta terceira versão foi aprimorada novamente com a realização de uma survey, que contou com a participação de 88 empreendedores, resultando numa proposta final de Framework Cíclico, validada e capaz de ser replicada por novos empreendedores.

\subsection{Justificativa}

Esta pesquisa contribui academicamente pois apresenta estudo sobre 0 processo de desenvolvimento de inovações no contexto das startups, campo de pesquisas ainda pouco estruturado na literatura relacionada. Desta maneira, a versão final do Framework Cíclico contribui com a literatura por combinar e conceituar assuntos de interesse que incluem a Cadeia de Valor da Inovação, o Design Thinking, a Lean Startup e o Business Model Canvas, temas emergente e carentes de análises e combinações mais aprofundadas.

Os resultados obtidos com esta pesquisa também contribuem de maneira prática com o processo de geração e refinamento de conceitos para novos negócios, pois é apresento um Framework Cíclico que propõe um processo ágil e que não demanda aprendizados complementares. A agilidade viabilizada pelo Framework também potencializa a geração de inovações radicais, amplamente buscadas pelas organizações tendo em vista sua sobrevivência no conturbado contexto atual. A geração e refinamento de conceitos em si são possíveis graças à utilização de abordagens como o Design Thinking, com suas ferramentas estimuladoras de criação de novas ideias, que auxiliam na obtenção de ideias mais alinhada com as necessidades e desejos dos clientes. Esta abordagem é potencializada e complementada com o emprego de pontos defendidos pela teoria da Lean Startup, tais como prototipação e feedback do consumidor, que podem ser representados graficamente e de maneira objetiva com o uso do Business Model Canvas.

\subsection{Estrutura do trabalho}

Para elaborar a proposta do Framework Cíclico inicialmente foi desenvolvida revisão bibliográfica relacionada aos assuntos de interesse (Cadeia de Valor da Inovação, Design Thinking, Lean Startup e Business Model Canvas), na qual se buscou o entendimento e definições claras destes conceitos, já que se tratam de assuntos que ainda geram contradições quanto ao seu significado e aplicação. 
Assim, iniciou-se a revisão bibliográfica com o tema Inovação, considerando em especial a Cadeia de Valor da Inovação enquanto proposta de sequencia de fases a serem seguidas na aplicação do Framework, atuando como elo integrador entre as demais abordagens deste estudo. Em relação à Inovação, uma área que merece destaque é o Design, que recentemente aumentou sua visibilidade graças à divulgação para as demais áreas do conhecimento da abordagem do Design Thinking, que contribui com o Framework na geração de insights inovadores. $\mathrm{O}$ referencial é complementado com a incorporação do tema Empreendedorismo, em especial a abordagem da Lean Startup, que contribui com o Framework apresentando conceitos como prototipação, feedback do consumidor, flexibilidade e agilidade. Com estas ideias inovadoras em mente surge a necessidade de estruturar - Modelo de Negócios e uma forma de boa síntese e comunicação visual é o Business Model Canvas, selecionado para compor o Framework por permitir a estruturação do plano de valores de uma organização e facilitar o teste das hipóteses desenhadas pelo Lean Startup. Os resultados da revisão bibliográfica são apresentados de forma detalhada no capítulo 2, com o desenvolvimento da definição dos assuntos de interesse.

No capítulo 3 apresenta-se o método de pesquisa, incluindo as etapas de painel de especialistas, que apresentou o Framework Cíclico proposto para especialistas focados em startups, buscando a sua opinião para o seu aprimoramento. Ainda neste capítulo é apresentada a aplicação da survey junto a empreendedores de startups de sucesso, com mais de um ano e que tenham passado ou estejam passando por processo de aceleração em aceleradoras brasileiras, mais uma vez buscando o aprimoramento do Framework e potencializando a assertividade dos resultados do estudo por meio do emprego de análise fatorial.

O capítulo 4 apresenta os resultados alcançados nestas etapas da pesquisa, incluindo análises e comentários, de forma explicar todo o processo de desenvolvimento do Framework Cíclico, principal objetivo deste estudo, o qual é detalhado possibilitando a sua aplicação por empreendedores de novas startups. $O$ capítulo 5 apresenta os resultados finais desta pesquisa, detalhando a conceituação e a forma de aplicação do Framework Cíclico obtido. Finalmente, o capítulo 6 expõe as conclusões finais e apresenta recomendações para estudos futuros. 


\section{REVISÃO DE LITERATURA}

De acordo com Boote e Beile (2005) a revisão de literatura é o fundamento e a inspiração para uma pesquisa substancial e útil, sendo pré-condição para o seu sucesso, já que uma pesquisa relevante permite o avanço do conhecimento e para isso é necessário compreender o que já se sabe sobre os temas de interesse.

Considerando a proposta deste estudo, elaborar um Framework Cíclico que auxilie as startups em seu processo de geração e refinamento de conceitos e na estruturação inicial das suas operações, torna-se necessário buscar entendimento aprofundado sobre as abordagens selecionadas (Cadeia de Valor da Inovação, Design Thinking, Lean Startup e Business Model Canvas), reconhecidamente úteis na estruturação deste tipo de empreendimento e que, quando combinadas, permitirão o estabelecimento deste Framework. As interligações das abordagens selecionadas são ilustradas pela Figura 1.

Figura 1: Esquema da revisão de literatura

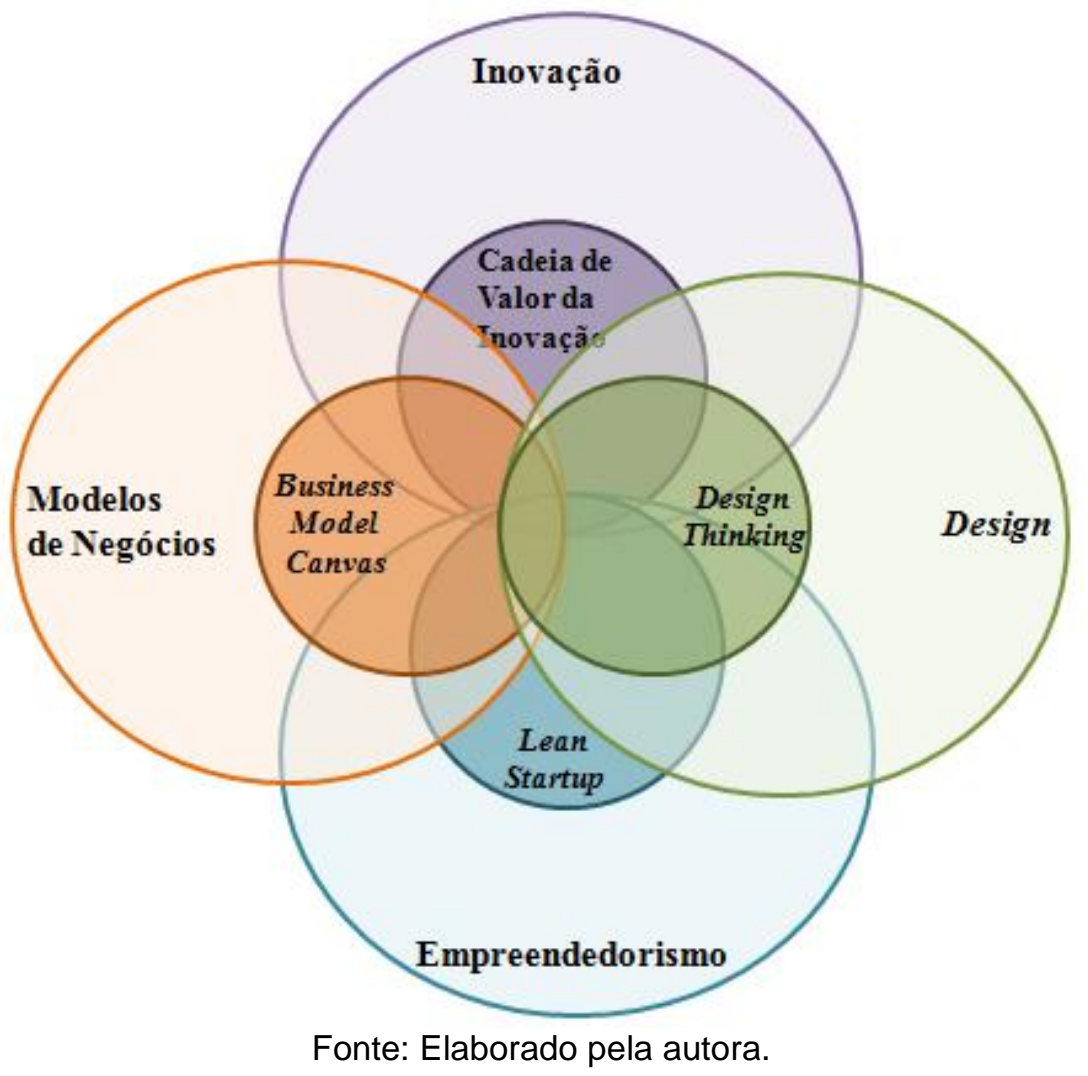

Detalhando a Figura 1, inicialmente a busca pelo entendimento sobre o termo

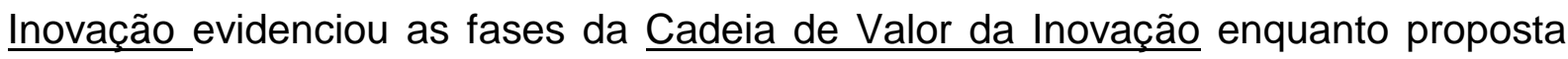
relevante na estruturação de uma organização inovadora. Durante a jornada buscando encontrar abordagens que auxiliem no processo de geração e difusão de 
Inovações tornou-se relevante aprofundar os conhecimentos na área de Design, que tem na sua essência a busca pelo novo, e que atualmente difunde suas ferramentas, métodos e forma de pensar entre as demais áreas do conhecimento por meio do Design Thinking.

Uma vez contando com um referencial de fases para estruturar a Inovação e uma proposta para que esta fosse mais facilmente alcançada (Design Thinking), tornou-se relevante obter melhor entendimento sobre o tema Empreendedorismo, marcado amplamente pela tentativa no estabelecimento de um novo negócio, pela busca por inovar, contexto que evidencia a abordagem da Lean Startup, metodologia ágil que trabalha com conceitos como prototipação e feedback dos clientes. Finalmente, surge a necessidade de estabelecer e comunicar o Modelo de Negócios da organização, preferenciamente de forma visual, e para isto foi utilizado o Business Model Canvas, capaz de fornecer um desenho simples porém estruturado do modelo de negócios de uma organização.

\subsection{Inovação}

Para o Manual de Oslo (1997), inovação é a implementação de um novo ou significativamente melhorado produto, serviço, método de marketing ou método organizacional, capaz de transformar as práticas de negócios. Já para Biancolino, Maccari e Pereira (2013) inovação é a implementação de novos serviços, produtos, processos, métodos de produção, mercados ou organizações. A inovação pode ser muito relevante para o crescimento e para o desenvolvimento organizacional, já que contribui com a empresa em questões prioritárias como o desenvolvimento de novos produtos (BONAZZI; ZILBER, 2014).

Segundo Drucker (1980), inovação é a capacidade organizacional de produzir uma riqueza inteiramente nova, em termos sociais e técnicos, levando ao abandono sistemático das práticas do passado. Ainda conforme o autor, inovar inclui a pesquisa de oportunidades inovadoras, seja de oportunidades tecnológicas, de mercado ou de processo, além da identificação de necessidades e anseios do mercado, sendo considerada uma iniciativa empreendedora, fruto da vontade de organizar, buscar novos negócios e não apenas modificações em produtos antigos, algo considerado como essencial para o sucesso das organizações nos próximos 
anos. Vianna et al. (2011) afirmam que, de forma tradicional, pode-se considerar a inovação como sendo a busca por novas soluções tecnológicas.

Davila (2009) considera a inovação necessária para o crescimento organizacional, capaz de produzir mudanças essenciais para que as organizações sobrevivam e evoluam, influenciando os rumos da indústria. Já para Tidd, Bessant e Pavitt (2008), a inovação é movida pela capacidade de detectar oportunidades, tirar proveito das mesmas e estabelecer relações, que podem consistir na abertura de novos mercados, mas também no estabelecimento de novas formas de servir mercados maduros e estabelecidos. Segundo Hitt, Ireland e Hoskisson (2005), a inovação possui importância crescente no século $X X I$, sendo um processo de criação de produtos comerciais a partir de invenções, ato de desenvolver ou criar um novo produto ou processo. Ainda segundo Biancolino, Maccari e Pereira (2013), envolvem mudanças e permitem estabelecer oportunidades de geração de novos benefícios.

Para melhor definir o termo inovação apresenta-se uma proposta de síntese elaborada por Bonazzi e Zilber (2014) no Quadro 1.

Quadro 1: Definições de Inovação

\begin{tabular}{|c|c|}
\hline Autor / Ano & Definiçáo de Inovaçáo \\
\hline Schumpeter (1988) & $\begin{array}{l}\text { Uma ideia, um esboço ou um modelo para um novo ou melhorado artefato, produto, processo } \\
\text { ou sistema, suscetível de comercializaçấo e capaz de promover ganhos de riquezas. }\end{array}$ \\
\hline Drucker (1989) & $\begin{array}{l}\text { Uma abordagem que visa explorar oportunidades e maneiras de diferenciaçáo, baseada em um } \\
\text { processo tecnológico incerto. }\end{array}$ \\
\hline Clark e Wheelwright (1993) & $\begin{array}{l}\text { Um novo conhecimento gerado dentro ou fora do ambiente organizacional mediante o estabe- } \\
\text { lecimento de parcerias. }\end{array}$ \\
\hline Affuah (1998) & Novo conhecimento para oferecer um novo produto ou serviço que os clientes querem e precisam. \\
\hline Hitt, Ireland e Hoskisson (2002) & Processo para criar um produto comercial a partir de uma invençáo. \\
\hline $\operatorname{OCDE}(2005, \mathrm{p} .55)$ & $\begin{array}{l}\text { "Implementaçáo de um produto (bem ou serviço) novo ou significativamente melhorado, ou } \\
\text { um processo, ou um novo método de marketing, ou um novo método organizacional nas práti- } \\
\text { cas de negócios, na organizaçáo do local de trabalho ou nas relaçóes externas." }\end{array}$ \\
\hline Chesbrough (2003) & $\begin{array}{l}\text { Maneira de promover ideias, pensamentos, processos e pesquisas, a fim de melhorar o desenvol- } \\
\text { vimento de produtos, prover melhores serviços para clientes, aumentar a eficiência e reforçar o } \\
\text { valor agregado a partir de parcerias externas. }\end{array}$ \\
\hline Davila, Epstein e Shelton (2007) & $\begin{array}{l}\text { Abordagem relacionada à criaçáo e estruturaçáo de uma nova organizaçáo visando mantê-la } \\
\text { viva no mercado. Encontra-se relacionada à criaçáo de um conhecimento novo em tecnologias } \\
\text { e modelo de negócios. }\end{array}$ \\
\hline Tidd, Bessant e Pavitt (2008) & $\begin{array}{l}\text { A inovaçáo refere-se ao desenvolvimento de novas tecnologias para a elaboraçáo de novos pro- } \\
\text { dutos e serviços. Trata-se da forma como a organizaçáo age frente às mudanças, podendo atuar } \\
\text { como fonte de satisfaçáo de clientes e de funcionários. }\end{array}$ \\
\hline $\begin{array}{l}\text { Biancolino, Maccari e Pereira }(2014 \text {, } \\
\text { p. 415) }\end{array}$ & $\begin{array}{l}\text { "Implementaçáo de novos produtos, serviços, métodos de produçáo, processos, matérias-pri- } \\
\text { mas, mercados, métodos de marketing, organizaçáo e estruturas de mercado." }\end{array}$ \\
\hline
\end{tabular}

Fonte: BONAZZI, F. L. Z.; ZILBER, M. A. (2014, p. 620). 


\subsubsection{Dimensões das inovações}

Quanto às dimensões das inovações, para Tidd, Bessant e Pavitt (2008), as inovações podem ocorrer em nível de componente e chegar até a mudança completa de um sistema, considerando desde pequenos avanços como a melhoria de desempenho até uma tecnologia totalmente nova. Ainda segundo os autores, existem inovações radicais e inovações incrementais, sendo que as radicais transformam a forma como vemos ou usamos as coisas e as incrementais promovem pequenas mudanças em coisas existentes. Ilustrado pela Figura 2.

Figura 2: Dimensões da inovação

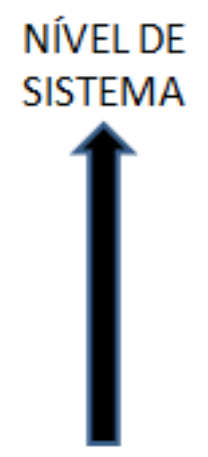

NÍVEL DE COMPONENTE

\begin{tabular}{|c|c|c|}
\hline $\begin{array}{l}\text { Novas versões de } \\
\text { motores } \\
\text { automotivos, } \\
\text { aviões, aparelhos } \\
\text { de TV }\end{array}$ & $\begin{array}{l}\text { Novas gerações, } \\
\text { como MP3 e } \\
\text { download versus CD } \\
\text { e fita-cassete }\end{array}$ & $\begin{array}{lr}\text { Energia a vapor, } \\
\text { "revolução" } & \text { da } \\
\text { Tecnologia } & \text { de } \\
\text { Informação } & \text { e } \\
\text { Comunicações } & \text { (TIC) } \\
\text { e biotecnologia } & \end{array}$ \\
\hline $\begin{array}{l}\text { Melhorias } \\
\text { componentes }\end{array}$ & $\begin{array}{l}\text { Novos componentes } \\
\text { para } \\
\text { existentes }\end{array}$ & \begin{tabular}{l}
\multicolumn{2}{c}{ Materiais avançados } \\
para melhoria de \\
desempenho \\
componentes
\end{tabular} \\
\hline
\end{tabular}

\section{INCREMENTAL}

RADICAL

("fazendo aquilo que

fazemos melhor)

Fonte: TIDD, J.; BESSANT, J.; PAVITT, K. (2008, pg. 32).

As inovações podem ainda ser classificadas como fechadas ou abertas; inovações fechadas tem foco no processo de desenvolvimento de produtos e serviços internos à organização e inovações abertas são marcadas pela porosidade entre a organização e o ambiente externo (CHESBROUGH, 2003). Chesbrough (2003) considera que na maior parte do século XX o modelo de inovação fechada funcionou muito bem, sendo aceito como caminho certo para que fossem trazidas novas ideias ao mercado e garantindo sucesso às organizações. Ainda segundo o autor, como eram estas as regras que regiam o mercado, as organizações mais inovadoras eram aquelas que realizavam maior investimento no processo de Pesquisa \& Desenvolvimento (P\&D) Interno, além da contratação dos melhores e mais brilhantes talentos; graças a todo este investimento, estas empresas obtinham as melhores idéias e alcançavam maior sucesso. Este processo também foi capaz de resultar em parcela significativa dos lucros, garantido com o agressivo controle da 
propriedade intelectual, capaz inclusive de proteger inovações organizacionais das réplicas criadas pelos competidores (CHESBROUGH, 2003). Ainda segundo o autor, a inovação fechada ocorre quando uma organização gera, desenvolve e comercializa suas próprias ideias, conforme o modelo da Figura 3.

Figura 3: Inovação fechada

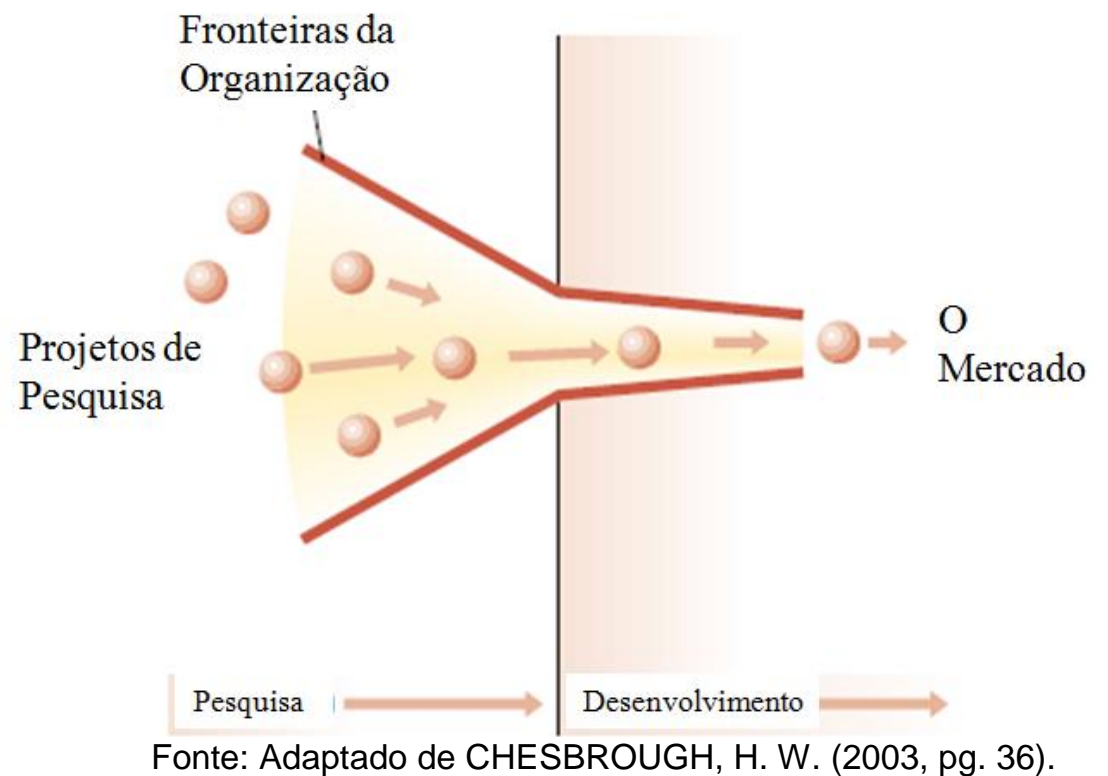

Porém, com o passar do tempo tornou-se mais difícil para as organizações controlarem completamente seu capital intelectual e, com o surgimento e consolidação dos fundos de Venture Capitals privados, capazes de auxiliar significativamente no financiamento de novas organizações, a equação apresentada anteriormente (maior investimento em $P \& D=$ melhores ideias) foi rompida (CHESBROUGH, 2003).

Segundo Chesbrough (2003), buscando estabelecer novas possibilidades para o desenvolvimento de inovações as organizações reduziram as barreiras entre seus processos internos e o meio externo, tornando as organizações mais porosas, estabelecendo então o modelo de inovação aberta. Ainda segundo o autor, a inovação aberta é baseada na percepção da existência de um ecossistema de abundante conhecimento, disponível para uso pela organização caso seja visto como de valor, seguindo o modelo da Figura 4. 


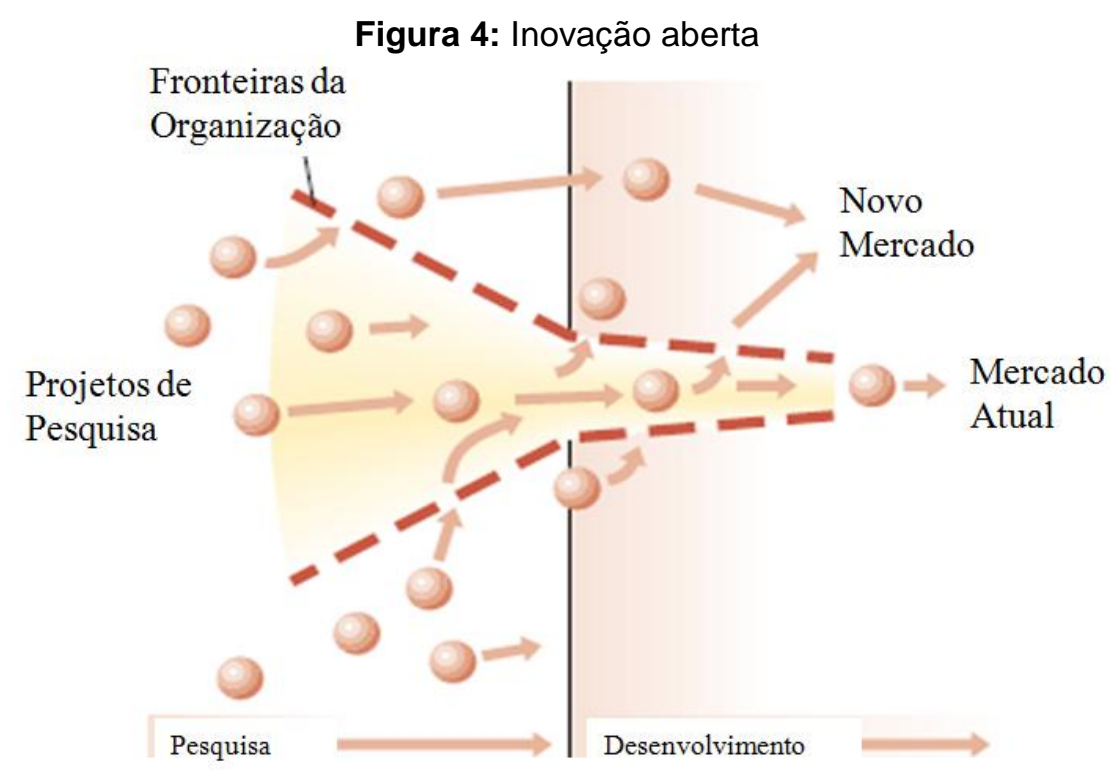

Fonte: CHESBROUGH, H. W. (2003, pg. 37).

Muitas organizações adeptas da inovação fechada tem foco tão interno que perdem diferentes oportunidades de inovar, já que muitas destas oportunidades encontram-se fora do seu ambiente de negócios habitual e necessitam da combinação e articulação de habilidades tecnológicas externas, inicialmente fora do seu alcance (CHESBROUGH, 2003). Para Chesbrough (2003), o que muda da inovação fechada para a inovação aberta é a gestão das ideias, já que na inovação aberta as empresas trabalham tanto as suas próprias ideias como as ideias provenientes de outras organizações, estabelecendo parcerias fora de seu ambiente de negócios habitual.

Tanto as inovações abertas como as inovações fechadas contam com um processo de pesquisa e desenvolvimento que inclui pesquisadores e gestores capazes de separar propostas boas de propostas ruins, viabilizando a seleção do que será desenvolvido e comercializado posteriormente (CHESBROUGH, 2003). Outro ponto em comum é que ambas estão sujeitas a encontrar ideias ruins que inicialmente aparentavam ser promissoras; porém, as organizações que desenvolvem inovações de forma aberta possuem maior habilidade em identificar projetos que inicialmente eram pouco promissores, mas que ao longo do tempo tornaram-se surpreendentemente valiosos (CHESBROUGH, 2003).

Ainda considerando as diferentes dimensões das inovações vale distinguir entre inovação autônoma e inovação sistêmica, onde a primeira caracteriza-se como inovação independente de outras inovações e a segunda é capaz de proporcionar benefícios quando promovida em conjunto com outras inovações, sejam estas 
complementares ou apenas relacionadas (CHESBROUGH; TEECE, 1996). Ainda segundo os autores, esta distinção de conceitos é importante para que seja selecionado o design da organização, onde inovações de tipologia distintas demandam estratégias organizacionais diferentes.

\subsubsection{Cadeia de Valor da Inovação}

Para Love, Roper e Bryson (2011), a inovação tem o seu processo conceitualizado pelos estágios da Cadeia de Valor da Inovação (CVI), que permitem que recursos e conhecimentos sejam gerados, transformando conhecimento em novos serviços com a finalidade de comercializá-los levando ao crescimento organizacional.

"A gestão da inovação é um processo estruturado que possibilita que uma organização perceba novas maneiras de criar valor e de antever demandas tecnológicas e mercadológicas" (VARANDAS JUNIOR; SALERNO; MIGUEL, 2014). Neste cenário, segundo os autores, temos a CVI estabelecendo um processo capaz de suportar a prática do desenvolvimento de inovações.

Para Roper, Du e Love (2008), a CVI representa o início de um processo que pode resultar numa melhoria de performance dos negócios, onde os recursos são descobertos, transformados e explorados. Nela são considerados os diferentes tipos de conhecimentos, provenientes de recursos distintos e então alcançado o estabelecimento das conexões com os diferentes elementos da CVI, viabilizando a transformação de conhecimento em inovação, incluindo novos produtos e novos serviços.

Hadida e Paris (2014) definem a CVI como uma sequência estrategicamente importante, pura e linear, interconectada com atividades que aumentam o valor, sendo um modelo que permite aos gestores encontrarem vantagens competitivas por meio do ordenamento e gestão do fluxo de produtos e serviços, desde a geração de ideias até o pós-venda, incluindo fornecedores, fabricantes, compradores e gestores. Para Handani e Wiraman (2012), o framework da CVI é utilizado para explicar como a inovação aberta pode auxiliar no sucesso e manutenção de uma organização, funcionando como um processo de transformação de ideias em saídas comercializáveis, como um fluxo integrável. 
Doran e O'Leary (2011) defendem que o framework da CVI vem sendo utilizado como modelo para analisar as inter-relações entre interações externas, produtividade e inovação. Para Ganotakis e Love (2012), o objetivo do modelo é refletir o processo do conhecimento organizacional necessário para o entendimento da inovação, transformando este conhecimento em novos produtos e processos e então explorando estas inovações para gerar crescimento e adicionar valor, mostrando de forma clara e severa as conexões no processo de inovação, do seu início ao fim.

Segundo Hansen e Birkinshaw (2007), existem dificuldades para as organizações inovarem e, como solução, propõe a CVI. De acordo com o Quadro 2, a CVI é composta por elos que a organização deve determinar afim de permitir a verificação dos pontos necessários relacionados às inovações, para que assim estas sejam esclarecidas e desenvolvidas adequadamente, permitindo o diagnóstico e a revisão do que for necessário antes do desenvolvimento completo de um novo produto ou serviço.

Quadro 2: Cadeia de Valor da Inovação

\begin{tabular}{|c|c|c|c|c|c|c|}
\hline & \multicolumn{3}{|c|}{ Geração de ideias } & \multicolumn{2}{|c|}{ Conversão } & \multirow{2}{*}{$\begin{array}{l}\text { Difusão } \\
\text { Propagação } \\
\text { Disseminaçåo } \\
\text { através da } \\
\text { organizaçăo }\end{array}$} \\
\hline & $\begin{array}{l}\text { Intraunidades } \\
\text { Criaçäo dentro } \\
\text { das unidades }\end{array}$ & $\begin{array}{l}\text { Polarização } \\
\text { Cruzada } \\
\text { Colaboraçäo } \\
\text { através das } \\
\text { unidades }\end{array}$ & $\begin{array}{l}\quad \text { Externa } \\
\text { Colaboraçäo } \\
\text { comparceiros } \\
\text { externos }\end{array}$ & $\begin{array}{l}\text { Seleção } \\
\text { Triageme } \\
\text { financiamento } \\
\text { inicial }\end{array}$ & $\begin{array}{l}\text { Desenvolvimento } \\
\text { Movimentaçäo das } \\
\text { ideias para os } \\
\text { primeiros } \\
\text { resultados }\end{array}$ & \\
\hline $\begin{array}{l}\text { Questões } \\
\text { Chave }\end{array}$ & $\begin{array}{l}\text { As pessogs das } \\
\text { sua s unidades } \\
\text { criam boss ideias } \\
\text { porsi? }\end{array}$ & $\begin{array}{l}\text { Nós geramos } \\
\text { boss ideiss } \\
\text { trabalhando } \\
\text { em conjunto } \\
\text { através da } \\
\text { organizaçäo? }\end{array}$ & $\begin{array}{l}\text { Nós temos } \\
\text { fontes externas } \\
\text { suficientes } \\
\text { para gerar } \\
\text { bogs ideias? }\end{array}$ & $\begin{array}{l}\text { Nós somos } \\
\text { bons em triare } \\
\text { finsnciar novas } \\
\text { ideias? }\end{array}$ & $\begin{array}{l}\text { Nós somos bons } \\
\text { em transformar as } \\
\text { ideias em produtos, } \\
\text { negóciose } \\
\text { melhores práticas? }\end{array}$ & $\begin{array}{l}\text { Nós somos bons } \\
\text { emdifundiro } \\
\text { desenvolvimento } \\
\text { de ideiss através } \\
\text { da organizaçäo? }\end{array}$ \\
\hline $\begin{array}{l}\text { Indicadores } \\
\text { de } \\
\text { Performance } \\
\text { chave }\end{array}$ & $\begin{array}{l}\text { Número de } \\
\text { ideias de alta } \\
\text { qualidade } \\
\text { geradas poruma } \\
\text { unidade }\end{array}$ & $\begin{array}{l}\text { Número de } \\
\text { ideias de alta } \\
\text { qualidade } \\
\text { geradas } \\
\text { através das } \\
\text { unidades }\end{array}$ & $\begin{array}{l}\text { Número de } \\
\text { ideias de alta } \\
\text { qualidade } \\
\text { geradas } \\
\text { externamente }\end{array}$ & $\begin{array}{l}\text { Porcentagem } \\
\text { de ideiss } \\
\text { geradas que } \\
\text { säo } \\
\text { selecionadase } \\
\text { financiadas }\end{array}$ & $\begin{array}{l}\text { Porcentagem de } \\
\text { ideiss finsnciadas } \\
\text { que deram retorno } \\
\text { financeiro, número } \\
\text { de meses para } \\
\text { primeira venda }\end{array}$ & $\begin{array}{l}\text { Porcentagem de } \\
\text { penetraçäo em } \\
\text { mercados alvos, } \\
\text { cadeias de } \\
\text { suprimentos e } \\
\text { clientes, número } \\
\text { de meses para } \\
\text { difusäo complets }\end{array}$ \\
\hline
\end{tabular}

Fonte: Adaptado de HANSEN, M. T.; BIRKINSHAW, J.(2007, p. 124).

Detalhando o processo da Cadeia de Valor da Inovação de acordo com Hansen e Birkinshaw (2007): 
- Geração de Ideias - momento no qual os executivos já sabem que as inovações vêm de boas ideias e o desafio é desenvolver algo novo, combinando ideias com conhecimentos de pessoas de diferentes partes da organização. Neste momento, segundo Varandas Junior, Salerno e Miguel (2014), as ideias são geradas internamente pela organização e com a integração passa-se a ter ideias mais elaboradas e melhores, podendo ser potencializadas com sua geração a partir de fontes externas. Segundo Doran e O'Leary (2011) e Handani e Wiraman (2012), neste momento os recursos de conhecimento podem ser externos ou internos à organização. Esta fase pode ser subdividida (HANSEN; BIRKINSHAW, 2007):

- Intraunidades - trata da elaboração de ideias dentro de uma unidade determinada da organização, com a geração destas ideias ocorrendo apenas internamente, sem abertura para ideias externas.

- Polarização Cruzada - conta com a colaboração entre unidades, marca o início da abertura da organização para receber ideias externas, mas ainda limitada apenas à própria organização.

- Externa - momento em que o ambiente externo à organização passa a ser envolvido na geração de ideias.

- Conversão - Varandas Junior, Salerno e Miguel (2014) consideram que para prosperar é preciso definição de objetivos claros e mecanismo financiador. Handani e Wiraman (2012) mencionam que neste segundo momento as ideias geradas anteriormente são selecionadas com base no que deverá ser financiado e desenvolvido futuramente. Para Doran e O'Leary (2011) este momento envolve a transformação do conhecimento no resultado da inovação. Segundo Hansen e Birkinshaw (2007) pode ser dividido em:

- Seleção - consiste no filtro das ideias boas que merecem melhor atenção, devendo ser levadas adiante, onde a viabilidade será avaliada em termos de diferentes critérios como disponibilidade de recursos e viabilidade econômica.

- Desenvolvimento - trata do desenvolvimento e avaliação das ideias selecionadas, mostrando as ideias que são válidas e merecem ter 
continuidade, podendo ser aplicada uma metodologia que permita a transformação das ideias em produtos.

- Difusão - quando os conceitos originais resultam nas inovações que são efetivamente selecionadas pela organização. Segundo Varandas Junior, Salerno e Miguel (2014), é neste momento que o desenvolvimento e o aprendizado devem ser compartilhados e, para sua conclusão, deve ocorrer a comercialização do produto e eventualmente a elaboração de um novo plano de negócios. Para Doran e O'Leary (2011), este estágio é caracterizado pela exploração da inovação, sendo também beneficiada com o aumento da produtividade do negócio e rentabilidade de produtos e serviços. Para Handani e Wiraman (2012) e Hansen e Birkinshaw (2007), a difusão ocorre quando a organização compartilha as ideias desenvolvidas com a sua comercialização já em escala e a sua inserção efetiva no mercado.

No estudo de Salerno et al. (2015), o modelo da Cadeia de Valor da Inovação é criticado por sua linearidade e foco em grandes organizações, que já possuem o departamento de Planejamento e Desenvolvimento estabelecido. Assim, segundo os autores, o modelo da CVI não é aderente a projetos que envolvam incerteza e complexidade, características típicas de inovações radicais. Para estes casos o estudo defende o uso do "processo com uma Interrupção", no qual o processo é similar ao tradicional, mas aborda a questão da incerteza relacionada a mercado, e assim considera uma pausa após o inicio das vendas iniciais, quando o produto ou serviço que vem sendo comercializado pela organização pode ser alterado, etapa denominada como "Espera por Mercado", conforme Figura 5. Com base nesta ideia verifica-se que esta pesquisa está alinhada com a proposta de Salerno et al. (2015), pois o Framework Cíclico desenvolvido segue a proposta de desenvolvimento de uma startup de forma cíclica, ou seja, permite que a ideia que está sendo comercializada possa ser revista e alterada sempre que seja julgado como necessário para o atendimento das necessidades dos consumidores e assim a sobrevivência organizacional. 
Figura 5: Processo com uma interrupção: Espera por Mercado

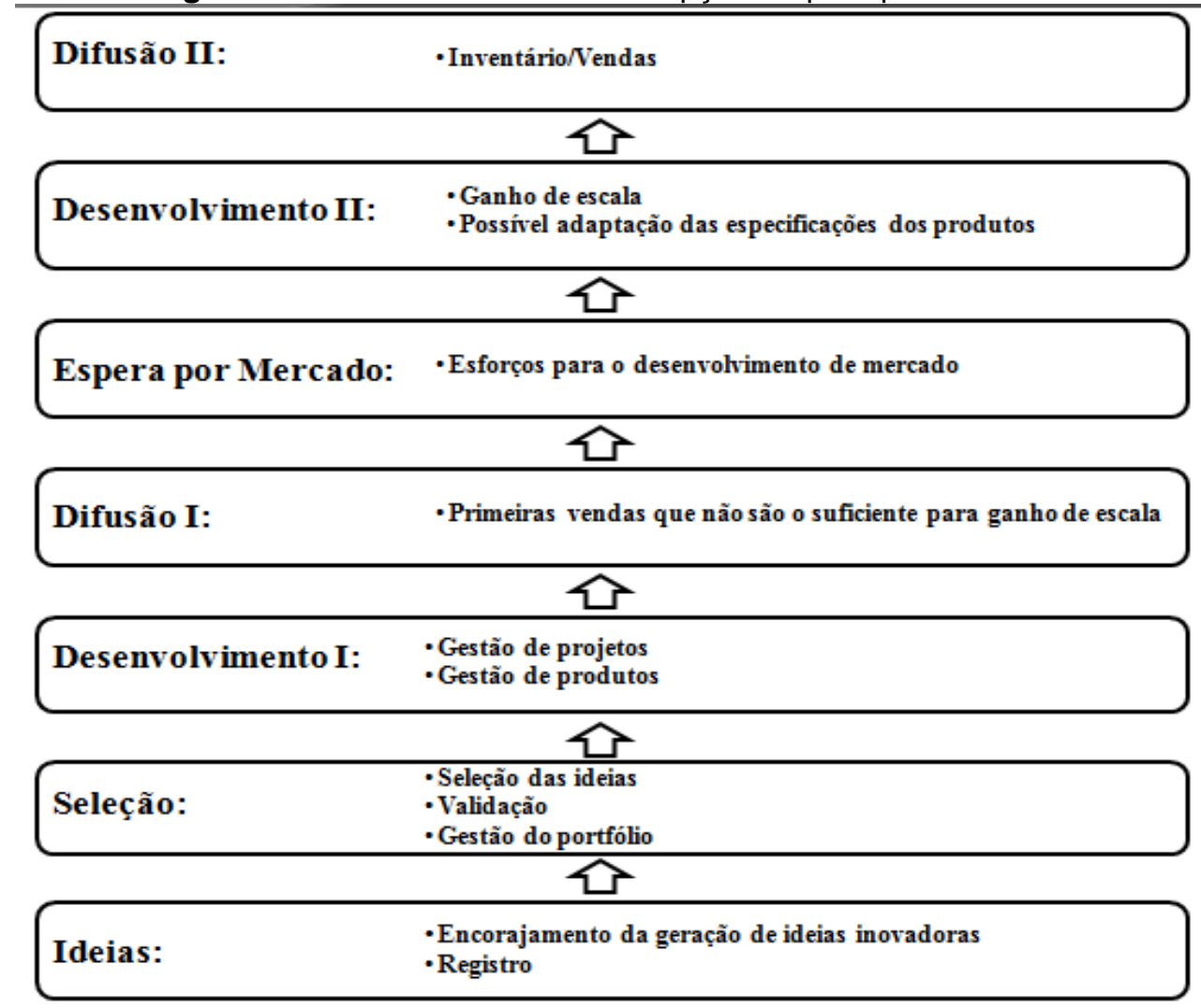

Fonte: Adaptado de SALERNO, M. S.; GOMES, L. A. V.; SILVA, D. O.; BAGNO, R. B.; FREITAS, S. L. T. U.(2015, p. 65).

A Cadeia de Valor da Inovação considera o processo existente de criação de inovações, desenhado como um framework que propõe questionar os executivos a respeito dos esforços para inovações (HANSEN; BIRKINSHAW, 2007). Considerando estas ideias, este estudo aborda a CVI enquanto proposta de sequencia de etapas a serem seguidas pelo Framework Cíclico em desenvolvimento, considerando o desenvolvimento de inovações.

Como conceito relevante relacionado com o tema inovação temos o campo do Design, área de conhecimentos reconhecida por suas soluções inovadoras e funcionais, capaz de atender ou mesmo superar as expectativas dos clientes.

\subsection{Design e seus profissionais}

Historicamente, o Design tem sido tratado como um passo menos importante no processo de desenvolvimento de produtos e serviços, onde os designers (profissionais da área de Design), que não desempenham nenhum papel no início do projeto, devem ao final colocar um belo invólucro na ideia implementada (BROWN, 2008). 
Porém o Design Thinking, ou seja, a forma de pensar do design, pode ser muito mais do que isto. Para Lawson e Dorst (2013), design é uma atividade fundamentalmente humana, uma profissão específica e um termo confuso, decorrência da sua natureza multifacetada, funcionando como um mix entre análise de pensamento e criatividade. Para Dorst e Cross (2001), o processo de design conta com a criatividade, caracterizada pela ocorrência de um evento significativo, algo difícil de ser estudado pelo fato de que não ocorre necessariamente durante um dado processo.

Para Christiaans e Venselaar (2005), existe consenso na literatura de que as competências em design provêm da experimentação do processo enquanto um solucionador de problemas. O processo de criação artística, segundo Risku e Abrahamsson (2015), pode atuar de forma complementar na evolução de uma ideia para o mundo real do artefato em desenvolvimento. Segundo Buchanan (1992), todos necessitam da arte liberal de design para viver bem, por ser esta a arte facilitadora para que os indivíduos participem de forma mais direta de algo e contribuam para o seu desenvolvimento. Para o International Concil of Societies of Industrial Design (2015), design é uma atividade criativa que busca estabelecer as qualidades de processos, serviços, objetos e seus sistemas em seus ciclos de vida, sendo ainda um fator central de humanização das inovações tecnológicas, além de ser um fator crucial em termos de trocas econômicas e culturais.

Neste cenário encontra-se o designer, que pode tornar-se mestre na exploração do novo graças à sua habilidade em descobrir relações entre ações, sinais e pensamentos, indicando que o design não é apenas uma técnica especializada, mas sim uma arte liberal (BUCHANAN, 1992). Schon e Wiggins (1992) consideram que a arquitetura do design é um processo de experimentação que inclui reflexões sobre as situações geradas. E estes profissionais são reconhecidos por estarem abertos a novas alternativas (VIANNA et al., 2011).

Cross (2006) considera que existe uma forma diferenciada de ação dos designers, e que esta ação separa estes profissionais dos profissionais originários das ciências e das atividades escolares típicas, graças ao seu método próprio de resolução de problemas, baseado principalmente no conhecimento tácito, de difícil externalização. Os designers são solucionadores de problemas complexos, que, quando consultados, estudam o problema pela perspectiva da experiência do consumidor. Os designers usualmente recebem os assuntos que deverão abordar 
em nível geral, cabendo à estes formular completamente as ideias que serão trabalhadas e as hipóteses relacionadas com a natureza do ser humano (BUCHANAN, 1992). Segundo Dorst (2011) e Vianna et al. (2011), estes profissionais trabalham com o pensamento abdutivo, no qual ocorre a busca por formular questionamentos pela compreensão ou apreensão dos fenômenos.

\subsubsection{Problematização da área de Design}

Quanto aos problemas abordados pela área de Design, Buchanan (1992) os define como indeterminados e fracos, já que não possuem solução única. Para Simon (1973), a diferença entre um problema bem estruturado e um problema mal estruturado é vaga, fluída e não totalmente formalizada, não se tendo uma definição definitiva e formal do que possa ser considerado como um problema bem estruturado e um problema mal estruturado. Porém, Simon (1973) indica as seguintes características de um problema bem estruturado:

- Existe um critério definido para testar as soluções propostas, além de um estado de solução ou um teste que as determine.

- Possui um conjunto de termos que caracteriza e descreve o problema inicial, assim como o seu objetivo e estados intermediários, que podem ocorrer no processo de tentativa de solução do problema.

- Possui mudanças de estado atingíveis, representadas no problema, sendo que o que caracteriza as mudanças são as transições de um estado para outro. Podem incluir um conjunto de operadores que mudem de um estado para outro, assim como as condições para o uso destes operadores.

- Nenhum conhecimento que o solucionador do problema possa adquirir deste poderá permitir a sua representação como um todo.

- O problema possui um conjunto para os testes detectarem a presença de diferenças entre pares de estado, tendo conexões com as diferenças entre os operadores, relevantes para remover e reduzir as diferenças.

- Todas as condições consideram o postulo processo, que requer a prática posterior da efetividade válida do processo.

Já para Rittel e Webber (1973), problemas mal estruturados são uma classe de sistemas sociais de problemas que, na verdade, são naturalmente mal 
formulados, incorporando informações que podem ser consideradas como confusas, em que vários consumidores e tomadores de decisões apresentam conflitos de valores e de interesses, existindo diversas ramificações no sistema. Numa tentativa de melhor definição dos problemas mal estruturados Rittel e Webber (1973) elencam suas propriedades:

1. Não possuem uma formulação definitiva, mas todas as suas formulações correspondem a diferentes soluções.

2. Não possuem regra de encerramento.

3. Possuem soluções boas e ruins e não certas ou erradas.

4. No seu processo de solução não existe uma listagem exaustiva para transições operacionais.

5. Possuem sempre mais de uma explicação.

6. São sintomas de um problema maior.

7. Não possuem soluções ou formulações definitivas.

8. A sua solução não deixa espaço para julgamentos e testes.

9. É único.

10. Os solucionadores não possuem o direito de errar e são plenamente responsáveis por suas ações.

Buchanan (1992) considera que o modelo linear funciona bem para a solução de problemas determinados, que possuem condições definidas; já para os problemas mal estruturados o autor sugere que existe uma indeterminação, de forma que não existem condições ou mesmo os limites claros para o design do problema, fato que pode ser superado com a aplicação do Design Thinking, já que o que muitos chamam de impossível pode apenas ser uma superável limitação da imaginação. Wells (2013) alega que o Design Thinking é essencial para o desenvolvimento de novas ideias e inovação.

Risku e Abrahamsson (2015) levantam a questão de que o Design Thinking está tornando-se popular fora das disciplinas de Design, observando que está ocorrendo um movimento positivo de contrabalanceamento dos princípios de design e hábitos com um conjunto de habilidades para pessoas fora da cultura de design. 


\subsubsection{Design Thinking}

Para Johansson-Sköldberg, Woodilla e Cetinkaya (2013), inicalmente é necessário o entendimento sobre a definição de Designerly Thinking antes do maior aprofundamento sobre o significado do termo Design Thinking. Para os autores Designerly Thinking refere-se à construção acadêmica e prática da área de Design, indo além da reflexão teórica sobre como interpretar e caracterizar as competências não verbais dos designers, de forma a conectar teoria e prática.

Já o Design Thinking é definido por Johansson-Sköldberg, Woodilla e Cetinkaya (2013) como uma excelente maneira para ser inovador e criativo, caracterizado pela aplicação das práticas dos designers. Ainda segundo os autores, sua utilização ocorre além do contexto do Design, por pessoas sem histórico na área, sendo uma versão simplificada e popularmente traduzida do Designerly Thinking ou mesmo uma maneira de descrever os métodos de Design que estão integrados entre o acadêmico e a prática de gestão.

Segundo Mueller e Thoring (2012), o Design Thinking está tornando-se cada vez mais conhecido, desde que foi popularizado pela consultoria de design IDEO nos anos 90. A IDEO (2012) afirma que para ter novas respostas são necessárias novas perspectivas, ferramentas e abordagens, propondo o Design Thinking como uma nova abordagem e o caracterizando como uma ação criativa que adiciona uma nova perspectiva ao trabalho.

Para IDEO (2012), Brown (2010), Vianna et al. (2011) e Dorst e Cross (2001), - Design Thinking utiliza da sensibilidade e da metodologia dos designers para o entendimento das necessidades que motivam o comportamento humano, vendo de forma diferenciada as situações e utilizando modelos e teorias que em conjunto criam entendimento da realidade humana, resultando em benefícios para os consumidores e valor para os negócios. Existe assim o poder de converter o valor para o consumidor em oportunidades para as organizações, beneficiadas pela visão de múltiplas perspectivas, com fundamentação na ideia de acreditar-se que é possível criar mudanças, dando permissão para falha e aprendizado, estando relacionada ao aprender e fazer.

Segundo a IDEO (2012), o Design Thinking ainda é um processo intencional que objetiva o novo, com soluções relevantes que criam impactos positivos, sendo um processo de transformação de dificuldades desafiadoras em oportunidade de 
Design. Segundo Vianna et al. (2011), num real significado o termo Design costuma estar relacionado a aparência estética de algo e/ou qualidade, mas na abordagem do Design Thinking é vista como uma disciplina que busca proporcionar bem estar na vida das pessoas. A abordagem chamou a atenção dos gestores pela forma como os designers percebem e agem sobre as coisas, abrindo caminho para a inovação e categorizando como problema tudo que prejudique o bem-estar, a experiência positiva e buscando gerar soluções (VIANNA et al., 2011).

Para Dunne e Martin (2006), o Design Thinking pode ser caracterizado como um processo mental, utilizado pelos designers para o desenvolvimento de um objeto, sistema ou serviço, combinando a geração de novas ideias com análises e avaliação de como generalizá-las, conforme ilustrado na Figura 6.

Figura 6: Modo de pensar dos designers

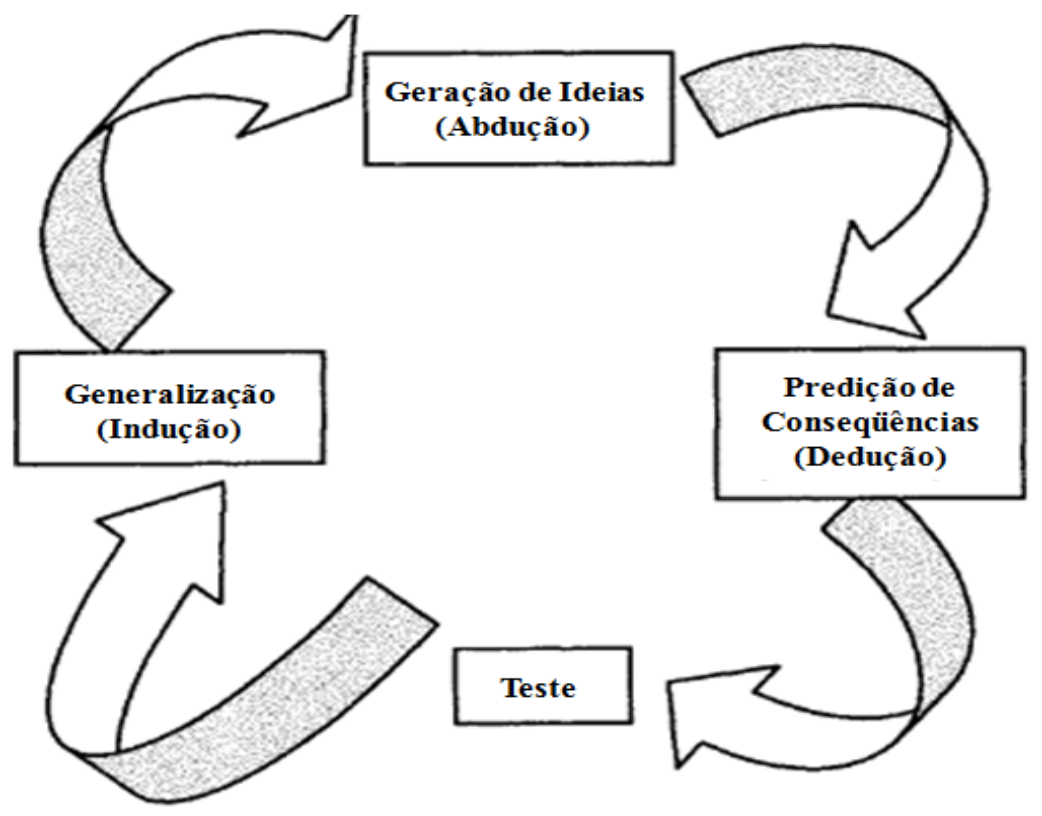

Fonte: Adaptado de DUNNE, D.; MARTIN, R. (2006, p. 518).

Para Micheli et al. (2012), a integração do Design Thinking com o desenvolvimento de novos produtos e serviços é desafiador, pois os designers das indústrias possuem diferentes objetivos e perspectivas quando comparados a outros membros da equipe de desenvolvimento de produto, o que pode levar a tensões; além disto as linguagens utilizadas são diferentes, podendo ocorrer problemas de comunicação

O Design Thinking é considerado como uma maneira de aumentar a criatividade, com foco em métodos específicos de design e a competência para o 
uso vindo da prática. É um novo conceito com características da pesquisa efetuada por designers e suas práticas que foram discutidas por mais de 40 anos (BUCHANAN, 1992).

Segundo Dym et al. (2005), o processo de Design Thinking reflete a complexidade de questionamento e aprendizado que os designers performam num contexto de sistema, tomando decisões como um processo, trabalhando de forma colaborativa, como um time. Ainda segundo o autor trata-se de um processo iniciado com questionamentos para definição do objetivo, buscado uma série constante de transformações do conceito de conhecimento. Para Vianna et al. (2011), não se pode solucionar um problema pensando da mesma maneira como este foi criado, sendo necessário o desvencilhamento do pensamento lógico cartesiano e pensar "fora da caixa".

Dorst (2011) levanta a questão de que nos últimos anos o Design Thinking tem ganho popularidade e que muitos modelos emergiram desde a primeiro vez que a abordagem foi mencionada, caracterizando formas diferenciadas de ver as situações da área de Design e aplicar seus modelos e teorias, os quais, em conjunto, criam uma variedade de entendimentos sobre a complexa realidade humana. Ainda segundo o autor, o desejo na utilização deste em outras áreas tem feito crescer a necessidade por uma melhor definição da abordagem, sendo o seu uso considerado como interessante pelo fato de que os designers lidam com problemas complexos e abertos e assim dominam práticas profissionais para este tipo de contexto.

Buchanan (1992), afirma que no século XX o Design Thinking cresceu, passando de uma atividade de comércio para um segmento profissional de uma área de pesquisa técnica. Ainda segundo o autor, na vida contemporânea não existe nenhuma área em que o Design não possa ser considerado como um fator importante para dar forma à experiência humana. Johansson-Sköldberg, Woodilla e Cetinkaya (2013) defendem que existem vários possíveis futuros para a aplicação do Design Thinking enquanto importante aspecto para os times de trabalhos.

\subsubsection{O DesignThinking e a Inovação}

Para Vianna et al. (2011), na busca de um novo caminho para a inovação surgiu o Design Thinking, abordagem que foca no ser humano, sendo 
multidisciplinar e tendo a capacidade de tangibilizar processos e pensamentos, com caminhos que levam a inovação. Ainda segundo Mueller e Thoring (2012), Design Thinking é uma estratégia de inovação. Já para Brown (2010) é uma ferramenta para imaginar experiências e dar a estas uma forma desejável, auxiliado a explorar rapidamente mais ideias e assim permitindo capturar insights inesperados e produzir inovações que reflitam as reais necessidades dos consumidores.

Ainda segundo Brown (2010), o foco na rápida experimentação e prototipação estabelece uma abordagem para a inovação, possuindo melhor explicação enquanto forma metafórica, onde em espaços existem diferentes relações de atividades que juntas formam as inovações, como arquitetura que diferencia do padrão linear de outras atividades de negócios. Para Buchanan (1992), a abordagem pode prover consequências surpreendentes para a inovação, por seu pensamento no futuro.

Segundo Beckman e Barry (2007), nos últimos 20 anos têm ocorrido uma codificação e formalização do processo de inovação, com as organizações atualmente lutando com o aumento e complexidade dos desafios na busca por soluções completas para seus consumidores em um ambiente de rápidas mudanças. Para Vianna et al. (2011), num mercado em que a concorrência é cada vez maior, é necessário traçar novos caminhos, os quais não devem ser buscados apenas para garantir o sucesso da organização, mas sua própria sobrevivência.

Considerando as necessidades dos consumidores, Dunne e Martin (2006) acreditam que os profissionais não têm sido ensinados a compreendê-las, não conseguindo desenvolver e evoluir melhorias com base na opinião dos consumidores. E neste cenário, ainda segundo os autores, surge o Design Thinking como um sistema que combina a geração de ideias com análises e avaliações, desenvolvendo melhorias com base no feedback dos consumidores. Para Brown (2010), a inovação é poderosa quando provem de um entendimento completo e de observações diretas do que as pessoas desejam e necessitam.

\subsubsection{As fases do Design Thinking}

Para Risku e Abrahamsson (2015), o Design Thinking possuí dois objetivos: auxiliar na resolução de problemas e criar soluções. Para os autores, na resolução de problemas devem ser considerados sete estágios: definição, pesquisa, ideação, prototipação, escolha, implementação e aprendizagem; por outro lado, na criação de 
soluções o seu início dá-se com o objetivo e a luta para conseguir uma solução alternativa para o desenvolvimento.

Para Dorst e Cross (2001), o processo de design é o que coloca o Design Thinking em ação, sendo uma abordagem estruturada para a geração e evolução de ideias, onde inicialmente é necessário a definição do desafio, assim como sua abordagem, entendimento e ação, devendo adotar um escopo claro. Ainda segundo os autores, existe outro início possível, onde são listados os possíveis tópicos e metas, elaborados de forma clara, sendo que após sua definição cabe o desenho do plano do projeto.

Segundo IDEO (2012), o Design Thinking é uma abordagem estruturada para a geração e evolução de ideias, existindo cinco etapas que ajudam na caracterização para solução do problema. Já para Brown (2010), o modelo conta apenas com três fases. E para Vianna et al. (2011), existem na verdade três macro etapas e uma sub-etapa de destaque. Considerando estas diferentes propostas de etapas, este estudo selecionou como melhor representação das etapas do Design Thinking a figura proposta por IDEO (2012), por se mostrar mais completa e detalhada.

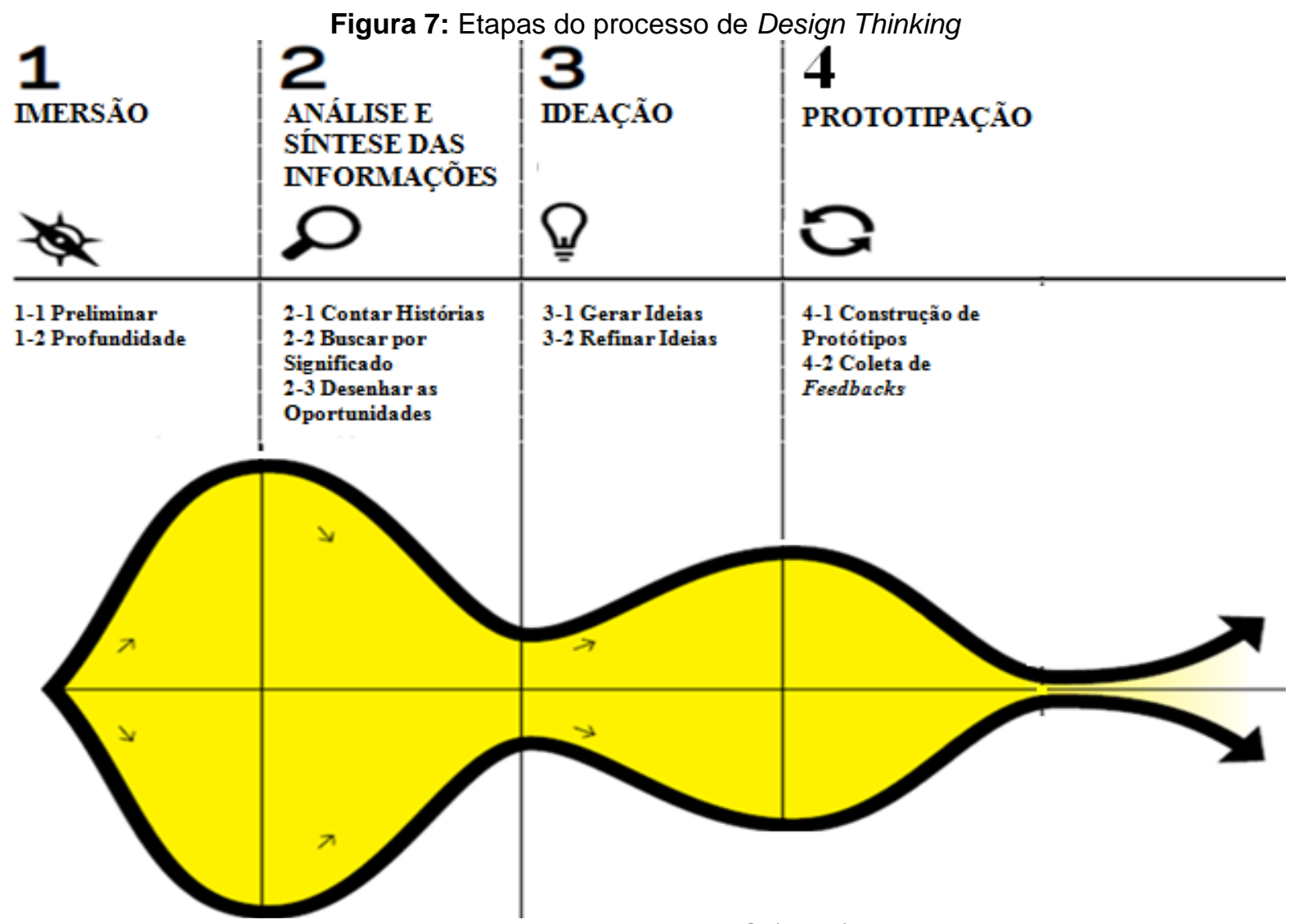

Fonte: Baseado em IDEO (2012). 


\section{Detalhando a Figura 7:}

- Imersão - para Brown (2010) é definida como fase de Inspiração, sendo o momento que provem da situação que motiva a busca por solução. Já para IDEO (2012), é a fase considerada como Descoberta, quando constrói-se uma sólida fundação das ideias, iniciando com profundo entendimento das necessidades dos usuários, estabelecendo a abertura para novas oportunidades com inspiração para criar novas ideias. Esta é a fase em que, segundo Vianna et al. (2011), ocorre a aproximação do contexto do problema, do ponto de vista empresarial e do usuário final, possuindo basicamente duas etapas:

- Preliminar - busca enquadrar e entender o problema inicial, ocorrendo uma reunião de alinhamento entre a equipe que conduzirá o projeto e os contratantes. Em paralelo ocorre uma pesquisa de campo preliminar (Pesquisa Exploratória) para auxiliar no entendimento do contexto, que será estudado profundamente na Imersão, sendo uma pesquisa que forneça referências de tendências da área estudada, com pesquisas em revistas, livros e internet. Outra necessidade é a definição do escopo e fronteiras do projeto, assim como a identificação do perfil dos usuários, já que muitas vezes no início não se conhece o problema. Ainda para IDEO (2012), é neste momento em que ocorre o "Entendimento do Desafio", onde cabe construir um entendimento comum entre os participantes do projeto. É importante ainda compartilhar e absorver o conhecimento, construindo um time forte, com um público alvo bem definido.

- Profundidade - objetiva identificar as necessidades e oportunidades que guiarão a geração de soluções na Ideação, tendo início com a elaboração do "Plano de Pesquisa", sendo utilizada uma técnica escolhida para mergulhar no contexto de uso dos produtos e serviços que serão explorados no projeto, buscando combinar as informações da etapa de Imersão com as tendências de mercado na busca por oportunidades e padrões, que serão posteriormente sintetizadas na fase de Ideação. Busca-se descobrir o que as pessoas falam, pensam e sentem, além de como estas agem, levantando oportunidades e criando soluções capazes de atender suas 
necessidades e desejos. Ainda para IDEO (2012), é neste momento que ocorre a "Preparação da Pesquisa", com questões bem desenvolvidas e estruturadas, além de regras bem definidas. Também ocorre a "Busca por Inspiração", que consiste em uma imersão observando o mundo ao seu redor e buscando a inspiração em diversos lugares, onde se deve aprender tanto com os especialistas como com os usuários, além de documentos e grupos.

- Análise e Síntese das Informações - é nesta etapa que, segundo a IDEO (2012), ocorre a transformação das histórias em insights. Para Vianna et al. (2011), esta etapa deve ser desenvolvida com base no que foi coletado nas etapas anteriores, organizando os insights para estabelecimento de padrão e compreensão do problema.

Neste momento sempre é válido possuir os "Critérios Norteadores" em mente, pois estes consistem nas diretrizes balizadoras do projeto, com aspectos que não devem ser perdidos de vista (IDEO, 2012). Ainda segundo a IDEO (2012), inclui as seguintes sub-etapas:

- Contar Histórias - consiste em, depois de cada reunião, dedicar-se a capturar o que foi aprendido e compartilhar, para um entendimento que construa um conhecimento comum no time.

- Buscar por Significado - depois de coletar as histórias é válido começar a fazer conexões, definindo-se os insights, que são o resultado do que foi aprendido pela pesquisa.

- Desenhar as Oportunidades - consiste na exibição visual dos insights. Esta etapa pode ser aprimorada com a aplicação das ferramentas propostas por Vianna et al. (2011):

- Personas - personagens fictícios com base no perfil dos consumidores observados, reunindo as características significantes de um grupo mais abrangente, como suas expectativas, necessidades, desejos e motivações. São desenvolvidos nesta etapa do projeto, mas podem ser utilizados diversas vezes, sempre que se deseje alinhar as informações dos usuários e pessoas envolvidas de forma a auxiliar no processo de design por conectar soluções com usuários. 
- Mapa de Empatia - sintetiza as informações sobre os consumidores numa nova visualização, analisando o que pensam, fazem, dizem e sentem, permitindo aos participantes compreender o contexto, as preocupações e os comportamentos dos usuários; quando se tem muitas informações é preciso organizá-las para um melhor entendimento do público-alvo.

- Jornada do Usuário - consiste em representar graficamente as etapas do relacionamento do consumidor com o serviço ou produto, de forma a descrever os passos do consumidor antes, durante e depois do processo de relação com a organização, proporcionando o entendimento do ciclo de relacionamento com o consumidor; pode ser utilizado em conjunto com as Personas.

- Blueprint - é uma matriz que representa de forma visual, simples e esquemática as interações que caracterizam a prestação do serviço, auxiliando na identificação dos pontos de melhoria e de oportunidades.

- Diagrama de Afinidades - transformação de tudo que foi coletado nas etapas anteriores em cartões com as informações categorizadas e organizadas de forma que possam ser acessadas facilmente, tendo-se a organização dos insights na busca pelo estabelecimento de padrões, onde os cartões são agrupados de acordo com suas similaridades, dependências e proximidade, gerando um diagrama com as subdivisões e interdependências, auxiliando na compreensão do problema.

- Ideação - Para Brown (2010), é o processo de geração, desenvolvimento e testes de ideias que podem levar a solução buscada. Já para IDEO (2012), é uma etapa que consiste em gerar diversas ideias. Para Vianna et al. (2011), neste momento é importante reunir diferentes expertises para que se tenha a contribuição de diferentes perspectivas, de forma a se obter um resultado mais assertivo e rico. Como proposta da IDEO (2012) temos neste momento as etapas de:

- Gerar Ideias - sessões de brainstorming, com um ambiente agradável e propicio, possibilitando a seleção de ideias promissoras. 
Para Vianna et al. (2011), neste momento cabe a busca por gerar ideias inovadoras, que costumam ter início com um brainstorming, técnica que estimula a geração de um amplo número de ideias dentro de um curto espaço de tempo, geralmente conduzida em grupo e tendo um moderador que estimula a criatividade.

- Refinar Ideias - olhar para o que é mais importante conforme a ideia e encontrar maneiras de desenvolvê-las, descrevendo as ideias definitivas. Neste momento, segundo Vianna et al. (2011), cabe o uso de algumas ferramentas:

- Sessões de co-criação - quando as ideias são capturadas ao longo do processo, podendo-se fazer uso do Workshop de Cocriação, quando são organizadas uma série de atividades em grupo para estimular a colaboração e criatividade.

- Cardápio de Ideias - consolida as ideias que serão validadas em reuniões com os consumidores, criando um catálogo que sintetiza todas as ideias geradas no projeto, podendo incluir observações e oportunidades de negócio.

- Matriz de Posicionamento - ferramenta de análise estratégica das ideias geradas buscando a sua validação de acordo com os "Critérios Norteadores" e as necessidades das "Personas" desenvolvidas no projeto, de forma a apoiar o processo de decisão e seleção das ideias mais relevantes para prototipação.

- Prototipação - para Brown (2010), é a Implementação, consistindo em colocar as ideias em prática. Segundo a IDEO (2012), é a Experimentação e proporciona vida às ideias, construindo protótipos que as tangibilizem, ocorrendo aprendizado na construção e compartilhamento. Para Vianna et al. (2011), auxiliam na validação das ideias geradas, podendo ocorrer ao longo do projeto em paralelo a Imersão e Ideação. É a representação real, a passagem do abstrato para o físico, a tangibilização de uma ideia, podendo ser apenas uma representação da ideia ou muito próximo da solução real, sendo que o seu teste pode ser efetuado em diversos ambientes, desde um laboratório até pelo próprio consumidor final. Ajuda na redução das 
incertezas de um projeto, pois possibilita abandonar uma ideia que não foi bem aceita, tornando mais fácil a identificação de uma solução mais assertiva. Pode incluir as seguintes etapas (IDEO, 2012):

- Construção de Protótipos - auxiliam no compartilhamento das ideias, pois podem ser discutidos para refinamento, podendo ser alterados com o tempo. Segundo Vianna et al. (2011) primeiramente ocorre a formulação de questões que devem ser respondidas em função das soluções que foram idealizadas, para então ocorrer a criação dos protótipos, modelos que representam o que será testado, com resultados que serão avaliados na forma de ciclo que será repetido até que seja possível chegar à solução final. Quanto mais cedo os testes forem desenvolvidos melhor, pois assim evita-se retrabalho, aumentando as chances de sucesso, conforme Figura 8.

Figura 8: Fluxo das etapas do processo de Design Thinking

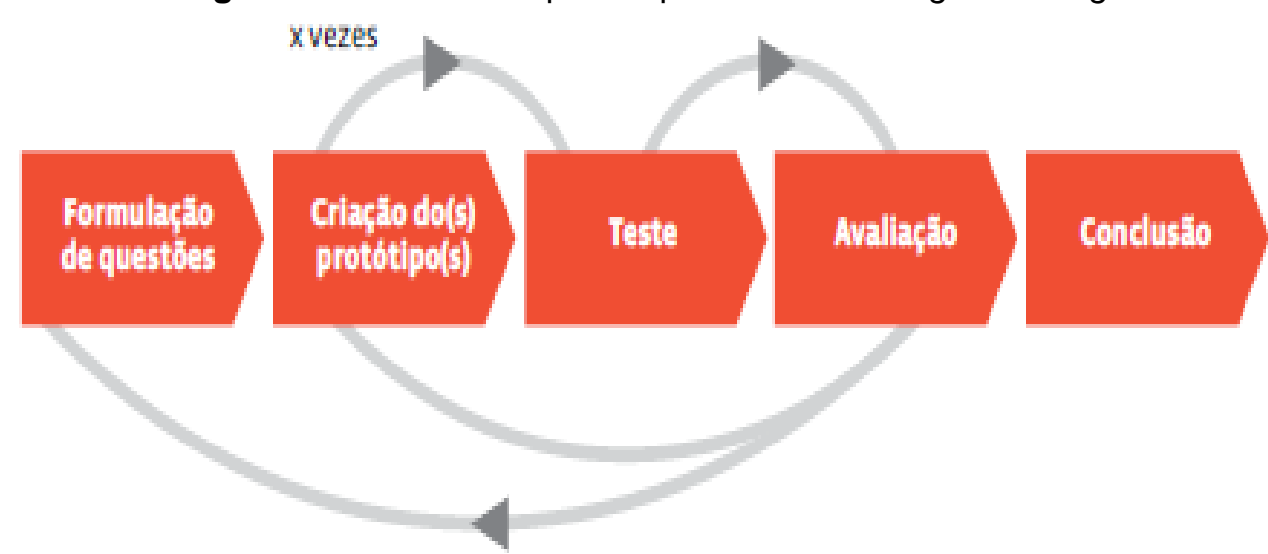

Fonte: VIANNA, M.; VIANNA, Y.; ADIER, T. K.; RUSSO, B.(2011, p. 124).

Ainda sobre protótipos, VIANNA et al. (2011) destacam:

- Protótipo em Papel - pode ser desde um desenho em uma folha de papel até uma embalagem final bem elaborada impressa, permitindo a avaliação do fluxo.

- Modelo de Volume - é um modelo do produto, podendo ser pouco ou muito detalhado, concretizando algo para que possa ser validado.

- Encenação - é uma simulação que pode ir desde a interação de uma pessoa com uma máquina até uma simulação de atendimento, permitindo construir e detalhar as etapas de forma a melhorar a experiência. 
- Storyboard - utiliza recursos visuais como desenhos e fotos para contar uma história, ajudando na detecção de aspectos abertos.

- Protótipo de Serviços - envolve o usuário e simula a solução proposta, representando alguns aspectos do serviço.

- Coleta de Feedbacks - o compartilhamento do protótipo gera feedbacks e no contexto do Design Thinking sua coleta é considerada a ferramenta mais importante para o desenvolvimento de uma ideia. Além de ser criado um ambiente que encoraje as pessoas a participarem, é importante reservar tempo após a sessão para absorver o que foi aprendido. A maioria das ideias não pode ser plenamente realizada com apenas um protótipo, sendo importante a iteração contínua.

Finalizando esta etapa chega-se à "Avaliação", proposta pela IDEO (2012) como o desenvolvimento dos conceitos no tempo, envolvendo o planejamento dos próximos passos com as etapas de:

- Trajetória do Aprendizado - define o que é o sucesso e estabelece medições sobre o seu alcance.

- Avanços - consiste em planejar os próximos passos e engajar outras pessoas, pois quando realmente acredita-se em uma proposição fica mais fácil conseguir convencer os outros.

As etapas, sub-etapas e ferramentas apresentadas auxiliam as organizações para que estas consigam aplicar com sucesso a abordagem do Design Thinking.

\subsection{Empreendedorismo}

Segundo Guedes (2015), o empreendedorismo é o principal motor de uma economia. Para Maurya (2012), estamos na era do empreendedorismo, com uma quantidade de empreendedores nunca antes vista, estabelecendo um ambiente propicio para inovar, com as organizações buscando inovar mais a cada dia. Para Saravasthy (2001), se já existe conhecimento sobre o que a organização deseja criar então é possível utilizar apenas as teorias existentes; porém o empreendedorismo tem início com algo mais amplo, como por exemplo um desejo 
de enriquecer ou mesmo de ofertar novo valor a um possível consumidor. Então, de acordo com Saravasthy (2001), existem duas alternativas de caminho:

- Causation - baseado na lógica preditiva e considerando um processo de efeito particular já identificado e focado na seleção de criação e efetivação, buscando maximizar os retornos potenciais para cada decisão com a seleção de uma estratégia otimizada. Enfatiza o detalhamento de análises competitivas, tendo em vista os aspectos preditivos de um futuro incerto. Neste as opções são identificadas e então se busca as melhores práticas possíveis para trabalhar dentro do já estipulado, na tentativa de alcançar os melhores resultados possíveis.

- Effectuation - baseado na lógica de controle, o processo considera significados e foca na seleção de possíveis efeitos criados a partir do conjunto de significados identificados preliminarmente. É um processo que permite ao empreendedor criar uma série de alternativas com um objetivo determinado previamente, permitindo ainda que o objetivo seja alterado, construído ou mesmo modelado ao longo do tempo. Busca identificar o máximo de opções dentro dos limites identificados, sendo experimental, enfatizando alianças estratégicas e priorizando considerações provenientes das partes interessadas para eliminar ou mesmo reduzir as incertezas, além de erguer barreiras de entrada. Foca nos aspectos controláveis de um futuro incerto. Esta alternativa inclui a abordagem do Lean Startup.

No tema empreendedorismo é importante destacar a Ação Empreendedora, definida por Lenzi, Kiesel e Zucco (2010) como a "ação" por parte do empreendedor, que deve ser o primeiro passo em sua trajetória e que deve ser caracterizada como a busca por fazer algo que gere resultados alinhados com as oportunidades de mercado e com a realidade das necessidades identificadas. Ainda segundo os autores é a "ação" e a atitude que caminham juntas numa busca pela perpetuação do empreendedor em seus segmentos de atividades e a busca pela inovação.

Segundo Kiss, Danis e Cavusgil (2012), existe pouca literatura relacionada ao assunto empreendedorismo mesmo com o significativo crescimento deste assunto no cenário global, percepção confirmada por este estudo quando o assunto foi buscado nas bases de dados. Porém, um assunto relacionado com 
empreendedorismo e que vem ganhando destaque é o Lean Startup por abordar conceitos como prototipação, feedback do consumidor, flexibilidade e agilidade.

\subsubsection{Definindo Lean}

Para definir o termo Lean Startup é relevante caracterizar o termo Lean, cuja origem relaciona-se com o termo Lean Manufacturing, definido como a busca pela eliminação de desperdícios e pela eficiência superior na utilização dos recursos. Segundo Yang, Hong e Modi (2011), o Lean Manufacturing é uma estratégia, filosofia ou conceito dependente de um conjunto de ferramentas e práticas para a implementação de uma minimização de desperdícios, buscando melhorar a performance da organização.

Nirwan e Dhewanto (2015) declaram que o Lean Manufacturing também recebe o nome de Lean Thinking, famosa abordagem de gestão aplicada ao sistema de produção da Toyota. Rasmussen e Tanev (2015) enfatizam que o termo Lean é utilizado para enfatizar a origem da ideia por trás da metodologia onde existe o foco na eliminação de desperdícios e emprego de esforços em tarefas que não agregam valor. Neste contexto o Lean Startup busca maximizar o aprendizado relacionado com o consumidor (MAURYA, 2012).

\subsubsection{Definindo Startup e termos associados}

Após a definição da variável Lean torna-se relevante definir o termo startup. Segundo Blank (2012), Hartmann (2013), Karlsson e Nordström (2012), Blomberg (2012) e Ries (2011), as startups são organizações desenhadas temporariamente na busca de um modelo de negócios replicáveis, rentáveis e escaláveis. Para Terho et al. (2015) uma startup busca um mecanismo que defenda grandes ambições, inovações e crescimento, podendo também ter origem nas unidades de negócio de uma organização existente, tendo como foco a exploração de novas oportunidades. Para Ries (2011), tratam-se de instituições humanas com o intuito de criar um novo produto ou serviço em condições de extrema incerteza. Para Blank (2012) são organizações formadas para a busca de um modelo de negócios replicável e escalável. Já para Thiel e Masters (2014), startups são constituídas pelo maior número de pessoas que podem ser convencidas a atuar em direção a construção de um futuro diferente, baseadas em um mesmo plano de desenvolvimento. 
Tratando da origem do conceito de startup. Alguns autores afirmam que o termo surgiu no Vale do Silício, na Califórnia (NOVAES, 2015; GITAHY, 2010). De acordo com Novaes (2015), este local concentra as principais organizações de eletrônica, tecnologia da informação, informática e computação. Ainda segundo Novaes (2015) e Kenney (2000) apud Miguel (2015), a região se desenvolveu a partir da Segunda Guerra Mundial, entre as décadas de 30 e 40, numa tentativa do governo norte-americano de superar tecnologicamente os alemães, tendo investido amplamente na criação de um laboratório secreto da Universidade de Harvard na Califórnia. O laboratório era chefiado por Frecrick Terman da Universidade de Stanford, que quando retornou à sua universidade convenceu seus pares para a criação de um centro de referência em Engenharia, de forma a obter melhores financiamentos do governo.

Outros pontos que incentivaram a criação do Vale do Silício foram a facilitação ao licenciamento de propriedade intelectual, iniciado nos anos 60 , e a redução dos impostos relacionados aos ganhos de capital, verificado no final da década de 70, e que permitiu a ampliação da disponibilidade de crédito, facilitando a estruturação de grandes organizações. Para muitos o "marco zero" do Vale do Silício é caracterizado pelo momento em que Bill Hewlett e David Packard fundaram a Hewlett Packard (HP) em uma garagem. Ao longo da década de 70 e 80 passam a atuar protagonistas como Steve Jobs, Bill Gates e Larry Ellison, que deram origem à organizações como Apple, Microsoft e Oracle. Mais recentemente, em 1998 ocorre a criação do Google por Larry Page e Sergei Bryn e em 2004, merece destaque a história de Mark Zuckebrerg e o Facebook (CRUZ, 2011). No momento as empresas que iniciaram como startups representam $22 \%$ do Produto Interno Bruto norteamericano e geram $11 \%$ dos empregos (NATIONAL VENTURE CAPITAL ASSOCIATION DOS EUA apud GUEDES, 2015).

Segundo Leung et al. (2006), na fase inicial de uma startup a estrutura da organização é relativamente simples e o dono pode se confunde com o negócio, principalmente pela centralização do poder de decisão; neste contexto o foco é sobreviver com poucos recursos e identificar oportunidades de negócios. Nesta fase as empresas necessitam de membros que tenham competências e perspectivas complementares, além de compartilharem a visão da organização, já que as startups são organizações humanas e assim a soma da contratação de pessoas competentes e criativas na busca por criar uma cultura capaz de gerar resultados 
(LEUNG et al., 2006; RIES, 2011). Para Blank (2012), uma startup sem pessoas apaixonadas está fadada ao fracasso, sendo necessário à esta membros diferentes, com a mente focada na incerteza, com calor e velocidade estonteantes, onde o seu trabalho seja o principal direcionador de sua vida.

Quanto ao sucesso de uma startup Ries (2011) defende que este não se resume a estar no lugar certo, no momento certo e sim na capacidade de se estabelecer e seguir um processo correto, já que existem muitos players atuando no mesmo local ao mesmo tempo, porém nem todos conseguem estabelecer modelos de negócios de sucesso, pelo fato de não possuirem as ferramentas adequadas e também em virtude da falta de habilidades, que inviabiliza a execução da estratégia e leva a falhas.

Segundo Croll e Yoskovitz (2013), as fases na evolução de uma startup são:

1. Empathy - consiste em descobrir o real problema que a organização vai enfrentar, "saindo para fora do prédio", entrevistando pessoas, aplicando pesquisas. Ao final desta etapa é preciso ter certeza de qual problema será resolvido e como será a remuneração por isso.

2. Stickiness - busca construir algo para descobrir se realmente é válido, para então dar continuidade ao desenvolvimento da solução para o problema que foi descoberto e que se está tentando resolver.

3. Virality - quando algo se mostra válido deve ocorrer a sua divulgação.

4. Revenue - o momento de monetizar; antes os itens poderiam até ser distribuídos gratuitamente para que os consumidores tomassem conhecimento, porém neste momento o foco passa a ser a otimização da receita.

5. Scale - nesta etapa o foco é no crescimento no mercado, adquirir novos consumidores, podendo também ocorrer o investimento em novos canais de distribuição.

Os autores ressaltam que na fase de Empathy o foco é adquirir feedback qualitativo com o objetivo de encontrar um problema solucionável e uma solução que seja suficientemente boa para resolver este problema. Os autores também destacam que o problema necessita ser suficientemente "doloroso" para que as pessoas se importem com ele, as quais ainda devem ser em número suficiente para garantir a lucratividade da solução do problema. Um questionamento que deve ser feito ao 
próprio empreendedor trata da disposição deste em passar cerca dos próximos 5 anos de sua vida focado em tentar resolver este problema, cabendo ao empreendedor ter uma visão grande o suficiente para inspirar consumidores, empregados e investidores, tendo um modo acreditável de mostrar a possibilidade de futuro (CROLL; YOSKOVITZ, 2013).

Considerando os ambientes de estímulo ao empreendedorismo vale mencionar as incubadoras, que segundo Miller e Bound (2011) possuem programas que merecem notoriedade pela qualidade. Os autores mencionam também os Investidores Anjo e os fundos de Venture Capitals, que muitas vezes investem em aceleradoras (empresas que ofertam consultoria, treinamento e participação em eventos durante um período que pode ser de três a oito meses e em troca, as aceleradoras recebem participação acionária na startup) e funcionam como mentores e eventualmente trabalham em conjunto com a startup. Segundo Kohler (2016) as aceleradoras ofertam uma abordagem potente para nutrir as inovações provenientes de novos empreendimentos, grande desafio que faz com que necessitem ser desenhadas para adicionar valor as startups e assim criar inovações benéficas a todos. Outro tema relevante são os Clusters, que segundo Pe'er e Keil (2012) e Miller e Bound (2011) influenciam as startups graças à combinação de capacidades, mensurações e estoques de conhecimento, bem como com de estabelecimento de alianças.

Segundo Blank (2011), anteriormente o número de startups era limitado por:

- Custos para se conseguir o primeiro consumidor ou produzir algo errado.

- Longo ciclo de desenvolvimento da tecnologia.

- Falta de pessoas com vontade de arriscar.

- Número limitado de Venture Capitals.

- Experiência guardada como segredo.

Os dois primeiros pontos, ainda segundo o autor, foram resolvidos com 0 desenvolvimento de produtos que realmente são desejados pelos consumidores; o terceiro foi resolvido com a redução do risco; o quarto aspecto foi resolvido com o aumento do número de Venture Capitals e o último foi solucionado com os avanços da tecnologia. Neste novo cenário, segundo Ries (2011), surge a Lean Startup uma nova abordagem, capaz de criar continuamente inovações, construídas com base em modelos prévios de gestão e ideias de desenvolvimento. 


\subsubsection{Definindo Lean Startup}

Segundo Ries (2011) e Karlsson e Nordström (2012), o Lean Startup surge como uma nova abordagem, que busca criar inovações de forma contínua, construída com base em modelos prévios de gestão e ideias relacionadas a desenvolvimento de produtos, como por exemplo Lean Manufacturing, Design Thinking e Customer Development. Os dois primeiros temas foram apresentados anteriormente neste trabalho; por sua vez a metodologia do Customer Development teve início com Blank (2003), que defendia que as funções de Marketing e de estratégia de negócio numa startup deveriam ser consideradas tão importantes quanto o desenvolvimento do produto.

Para Järvi, Taajamaa e Hyrynsalmi (2015), o Lean Startup é um método com o objetivo de acelerar a evolução das startups e eliminar os desperdícios no decorrer deste processo, sendo que o movimento iniciou-se em empreendimentos ligados ao desenvolvimento de softwares e atualmente está sendo espalhado para áreas mais tangíveis (RIES, 2011). Anderson (2012) menciona que a Lean Startup foi criada para empreendimentos de tecnologia, mas acredita que possa ser replicado para outros negócios, existindo até mesmo instituições como Stanford, Harward, e Columbia que estão adicionando o modelo aos seus currículos e também empresas como GE, Qualcomm e Intuit, que já iniciaram o uso do modelo.

Segundo Nirwan e Dhewanto (2015), a metodologia do Lean Startup surge como uma nova abordagem para um empreendedor ser bem sucedido no desenvolvimento das ideias de negócios, já que o grande pesadelo para os novos empreendedores é que o seu negócio falhe depois que estes tenham despendido muito dinheiro e tempo. O Lean Startup surge como uma metodologia que foca em testes ágeis e ciclos de aprendizagem na busca de validação para as hipóteses das idéias do negócio, sendo empregado ao redor do mundo como uma forma de solucionar o medo de falha dos novos empreendimentos, tendo sido popularizado por Eric Ries em seu blog "The Lean Startup", no ano de 2008.

Já segundo Rasmussen e Tanev (2015), o Lean Startup é uma metodologia focada na tradução da visão do empreendedor em hipóteses para a elaboração de um novo produto em conjunto com o desenvolvimento de um modelo de negócios, envolvendo então o teste das hipóteses com o uso de protótipos que tem por objetivo validar as especificações relacionadas com o modelo de negócios. 
Para Silva et al. (2013), Ries (2011), Poppendieck e Cusumano (2012), Croll e Yoskovitz (2013) e Melo et al. (2013), o Lean Startup pode ser utilizado para o desenvolvimento de novos empreendimentos, serviços, produtos e tecnologias aplicando o pensamento Lean ao processo de inovação, resultando num conjunto de práticas que buscam aumentar as chances dos empreendedores na construção de uma startup de sucesso, funcionando como um framework que apresenta os passos a serem seguidos. É considerada como um método ágil, elaborada pela necessidade de priorizar os consumidores no direcionamento do trabalho a ser desenvolvido, utilizando o feedback destes consumidores para efetuar ajustes, entregando valor validado, direcionando a startup para o objetivo correto. Para Edison (2015), o foco do Lean Startup são esforços para criar valor para os consumidores e eliminar os desperdícios durante a fase de desenvolvimento. O Lean Startup é uma abordagem que auxilia os empreendedores a compreender se um produto deve ser construído ou não (EDISON, 2015).

Os principios do Lean Startup apresentados por Ries (2011) são os seguintes: 1 - Empreendedores estão em todos os lugares e buscam criar novos serviços e produtos em situações de extrema incerteza.

2 - Empreendedores são gestores e as startups demandam um novo modelo de gestão.

3 - Startups existem para construir negócios sustentáveis, capazes de fazer dinheiro ao servir bem os consumidores.

4 - O conceito fundamental de uma startup consiste na transformação de ideias em produtos, aprendendo com as respostas dos consumidores por meio de testes na utilização destes produtos, trazendo informações para que seja decidido entre preservar ou pivotar.

5 - Um novo design precisa ser elaborado para que o progresso possa ser mensurado e seja possível identificar o priorizável.

Giardino, Wang e Abrahamsson (2014) defendem que o modelo Lean Startup sugere uma proposta para abandonar o desenvolvimento tradicional de produtos e serviços e que busca descobrir e validar o mercado correto para uma ideia, onde o primeiro passo é identificar o problema correto a ser resolvido, seguido da construção do produto correto, capaz de atender as reais necessidades dos 
consumidores; se não ocorrer o encontro do mercado potencial com o produto então é preciso pivotar, retornar.

Blank (2012) classifica o Lean Startup como uma nova abordagem que busca tornar menos arriscado a criação de uma nova empresa, aplicando uma metodologia que defende a experimentação acima de planos estruturados, com o design iterativo no lugar do tradicional, podendo a metodologia ajudar na redução de falhas por se basear na opinião dos consumidores acima da intuição dos empreendedores. Segundo Harms (2015), o Lean Startup funciona como um exemplo de aprendizagem experimental em grupo, onde o empreendedor aprende enquanto experimenta na vida real. Para Anderson (2012), a abordagem da Lean Startup proporciona insights que permitem a mudança de direção de uma organização. Para Blank (2011), as três ideias fundamentais do Lean Startup são:

- No lugar de desenvolver um plano de negócios detalhado, coloque as suas hipóteses no Business Model Canvas, mostrando como a empresa cria valor para si e para os consumidores. Segundo Maurya (2012), o Business Model Canvas possui um formato mais ágil, sendo mais conciso e forçando a priorização de escolhas para atingir o objetivo, ajudando a identificar o que é essencial.

- Vá até o consumidor e pergunte sobre as propostas de valor do negócio; utilize este feedback para revisar e eventualmente complementar 0 modelo proposto.

- Utilize o desenvolvimento ágil, priorizando o trabalho junto ao consumidor, melhorando o produto em parceria com o consumidor. $\mathrm{O}$ modelo tem foco na execução e após algumas rodadas de feedback e experimentação chega-se à formulação efetiva da solução.

Karlsson e Nordström (2012) relatam que existem barreiras para a implementação das práticas de Lean Startup em grandes companhias:

- Giro/Repetição - pelo fato de que os patrocinadores dos projetos são inflexíveis e relutantes em relação à mudança de escopo, mesmo porque existem planos que foram previamente acordados com os financiadores e o time trabalha por um objetivo, que é difícil de ser alterado, o que se mostra mais simples nas startups que vislumbram vários objetivos. 
- Comunicação - é lenta nas grandes empresas, inclusive quando se trata de acesso aos consumidores, que costuma ser restrito, controlado por determinadas pessoas que costumam ser rigorosas neste acesso, pelo risco de danos a imagem organizacional. A comunicação em grandes empresas costuma ser mais lenta do que em startups, já que geralmente se tem mais pessoas envolvidas no projeto, resultando em mais conexões de comunicação. Segundo Ries (2011), um dos objetivos da Lean Startup é maximizar a velocidade do tempo despendido nas interações.

- Patrocinadores - geralmente focam apenas em tecnologia. Os financiadores em grandes empresas estão menos propensos a permitir giros e a repetições, fornecendo uma lista de requisitos que o time deve seguir, financiando o desenvolvimento de um projeto que desejam e não porque acreditam que o time irá criar algo de valor.

Blomberg (2012) destaca que o Lean Startup têm algo a oferecer, mas por ser ainda novo exige estudos para um melhor entendimento de seus princípios, encorajando o estudo mais profundo e detalhado.

\subsubsection{Fases do Lean Startup}

Segundo Cooper e Vlaskovits (2010) e Blank (2005), no Lean Startup ocorrem paralelamente os Processos de Desenvolvimento do Produto e do Consumidor, conforme a Figura 9. 
Figura 9: Paralelo entre o Desenvolvimento de Produto e Consumidor

\section{Desenvolvimento do Produto}

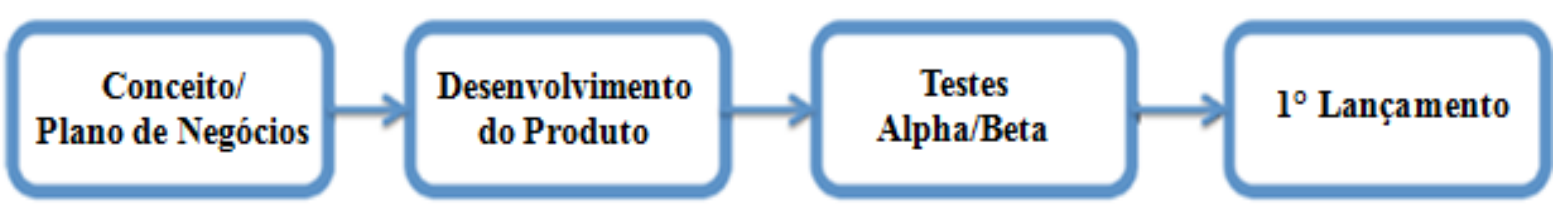

\section{Desenvolvimento do Consumidor}

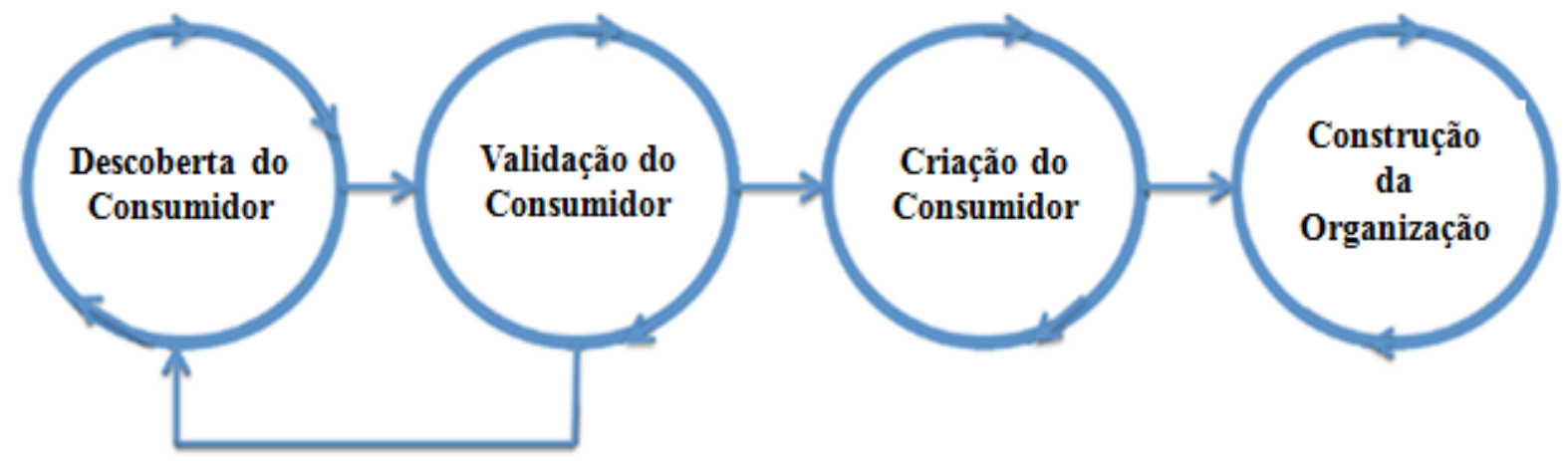

Fonte: Adaptado de BLANK, S.(2005).

Detalhando o Desenvolvimento do Consumidor temos a Figura 10.

Figura 10: Detalhamento do Desenvolvimento do Consumidor

\section{Desenvolvimento do Consumidor}
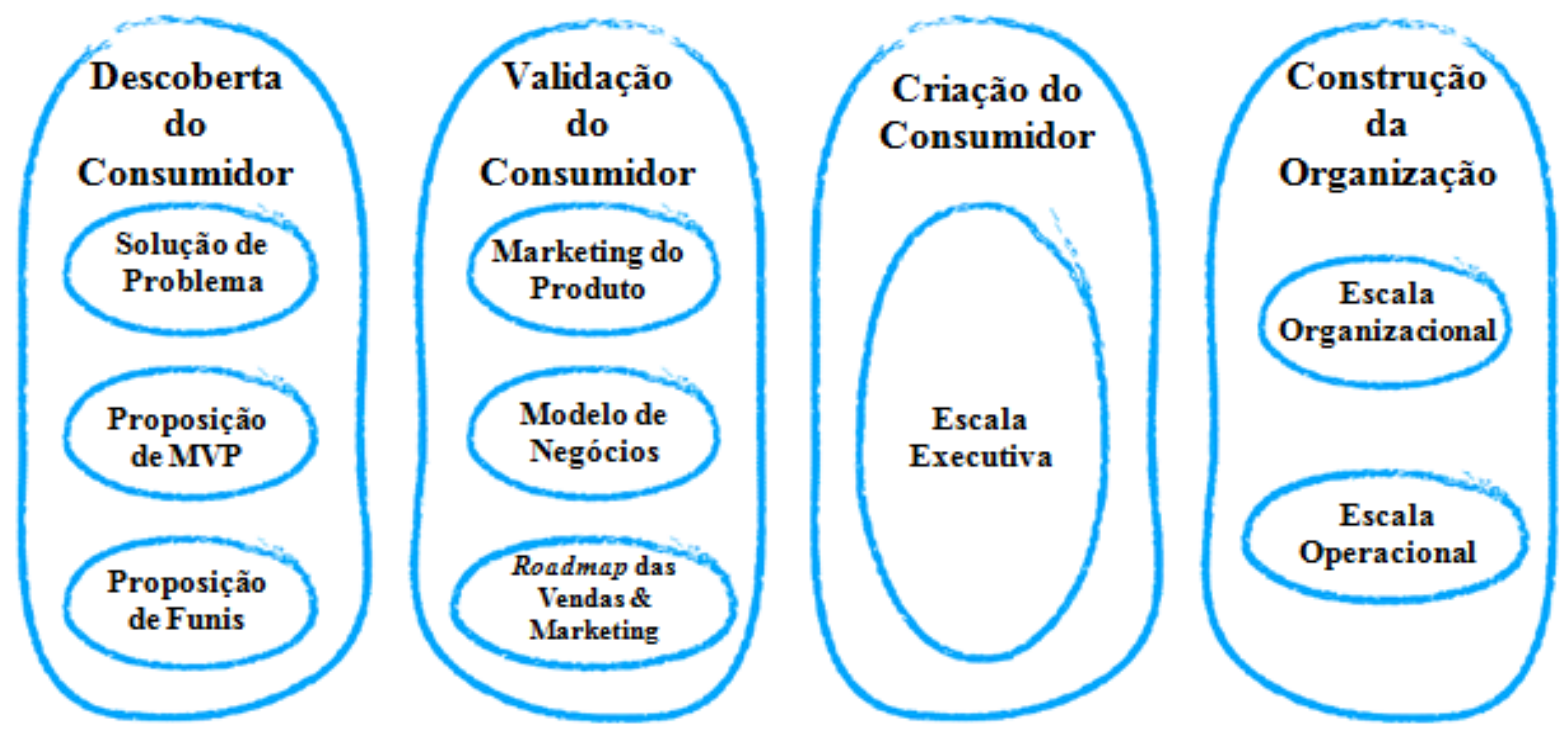

Articulação

Fonte: Adaptado de COOPER, B.; VLASKOVITS, P. (2010).

Segundo Blank (2012), o primeiro conjunto de etapas da Figura 10 inclui Descoberta do Consumidor, que consiste em transformara visão do fundador em 
uma série de hipóteses, que serão testadas para verificação das reações dos consumidores. Já o segundo conjunto trata da Validação do Consumidor buscando aprender e descobrir sobre este e, para que esta etapa funcione, é necessário que toda a organização tenha entendimento e concordância, aceitando um processo fluido, não linear e duradouro (BLANK, 2012). Outro ponto que merece atenção é a identificação dos problemas dos consumidores a serem resolvidos, momento em que a aplicação de abordagens como o Design Thinking prova-se muito úties (RIES, 2011).

Ainda segundo Blank (2012), na fase de Criação de Consumidor é preciso "sair do prédio" para testar as hipóteses em pesquisas repetíveis e escaláveis, transformando hipóteses em dados efetivos sobre o consumidor. Neste momento ocorre a execução da estratégia, estabelecendo a demanda e dirigindo canais de vendas, para que então seja possível a Construção da Organização, momento de transição da startup para uma organização com foco em executar o modelo de validação.

Um ponto central do Lean Startup é a interação com os consumidores, fontes de feedbacks e dados, considerados como mais importantes do que o retorno financeiro, pois podem influenciar um novo conjunto de ideias e possibilitar novos experimentos (RIES, 2011; BLANK, 2012). Considerando o feedback dos consumidores Tauberer (2011) e Cobb e Poirier (2013) mencionam que a filosofia do Lean Startup consiste na aplicação de ferramentas que permitem efetuar a intersecção entre os objetivos da organização e as necessidades e desejos dos consumidores. Neste momento a avaliação do consumidor em relação à sua aceitação e interesse pelo produto inicial testa a capacidade dos membros da organização em mudarem de direção, redirecionando o produto para as necessidades efetivas dos consumidores sempre que necessário. Blomberg (2012) destaca que é preciso buscar pelo consumidor correto para que se tenha o feedback correto.

Para Blank (2012), encontrar e ouvir o consumidor potencial é o que separa ganhadores dos perdedores e a pesquisa deve ser feita pelos fundadores, pois estes podem ouvir, reagir e tomar as decisões necessárias para alterar o plano de negócios conforme o feedback recebido, devendo existir flexibilidade, pois a diferença entre um plano de negócios estático e um modelo de negócios dinâmico pode ser a chave para o sucesso ou falha de um negócio. Ries (2011) alerta que o 
empresário, na empolgação do contato com o consumidor, pode tomar decisões sem análises mais aprofundadas; porém, como nem mesmo os consumidores normalmente sabem o que desejam, torna-se necessário vários contatos e análises detalhadas para então desenvolver um planejamento antes de iniciar a ação.

Para Karlsson e Nordström (2012), o Lean Startup exige contato ainda cedo com o consumidor e a interação é uma parte essencial da metodologia. As startups devem interagir com os consumidores ainda na elaboração do projeto, nos estágios iniciais, fato que não é comum nas grandes empresas, onde o projeto é avaliado internamente e dificilmente os engenheiros tem contato com o consumidor potencial para efetuar perguntas e então desenvolver melhorias, fazendo que o novo produto ou serviço acabe sendo apresentado para os consumidores apenas quando já finalizado (KARLSSON; NORDSTRÖM, 2012; TRIMI; BERBEGAL-MIRABENT, 2012). Ainda para Trimi e Berbegal-Mirabent (2012), uma das maiores razões para as falhas das startups é uma lacuna no processo de identificação de seus consumidores e na validação junto a estes ainda nos primeiros estágios de desenvolvimento. Para Maurya (2012), a primeira forma de validação após os teste é ser pago pelo que foi desenvolvido.

Uma vez que se têm consumidores identificados e a proposta de solução do problema validada, para Blank (2012), o próximo passo consiste em estabelecer as hipóteses nos nove blocos do Business Model Canvas, incluindo uma listagem dos testes e experimentos que deverão ser aplicados para aprovar ou não estas hipóteses. Para Ries (2011), inicialmente deve-se quebrar a grande visão da organização em duas partes:

- Hipóteses de Valor - que testam se realmente está sendo entregue valor ao consumidor.

- Hipóteses de Crescimento - que testam como novos consumidores irão decobrir o produto ou serviço.

Na opinião de Ries (2011), é preciso testar as hipóteses fundamentais sobre estratégia, produto e engenharia de crescimento para o desenvolvimento de um negócio sustentável. Uma startup precisa encontrar maneiras de obter um aprendizado válido contando com poucos recursos e tempo, devendo aplicar todas as técnicas do Lean Startup (RIES, 2011). Ainda é preciso realizar os testes rapidamente, no início, porque quanto mais desenvolvido e longo estiver o processo, 
maior será o medo de mudar e errar. Para Blank (2012), a tomada de decisão rápida e o pivotamento garantem agilidade dentro e fora da organização, conseguindo decidir e implementar decisões rapidamente, estabelecendo uma grande vantagem, que pode ser decisiva.

Neste momento deve-se gerar o Produto Mínimo Viável (PMV, do inglês Minimum Viable Product - MVP); segundo Ries (2011) e Croll e Yoskovitz (2013) o PMV consiste num produto que permite os testes das hipóteses, além de ser uma ferramenta que auxilia na descoberta sobre qual produto construir. Ainda segundo Ries (2011), Anderson (2012) e Blank (2012), o PMV é uma versão do produto que permite uma volta completa no ciclo apresentado na Figura 11, contando com o minimo de esforços e tempo de desenvolvimento, com foco em consumidores iniciantes e com os objetivo de aprendizagem.

Neste momento Ries (2011) recomenda que se tenha como participantes um representante de cada setor, para que as mudanças possam ser desenvolvidas e verificadas mais rapidamente, sem precisar esperar por aprovações. Para Ries (2011), o conceito de Lean Startup conta com o conceito de Aprendizagem Validada, método rigoroso para demonstrar o progresso quando se está num cenário de extrema incerteza como é o caso das startups, demonstrando empiricamente o que o grupo descobriu.

Segundo Ries (2011), uma falha comum em startups é o medo de burocratizar, que acaba por gerar nos empreendedores uma postura de "vamos fazer isso", evitando que se tenha disciplina, gestão e processos, levando ao caos. Ao invés de fazer planos com base em diversos assuntos, no Lean Startup fazem-se ajustes constantes, permitindo que o negócio cresça com o máximo de aceleração.

Para Terho et al. (2015), quando um negócio é baseado em extrema incerteza as hipóteses do negócio que constam em seu modelo de negócios devem ser testadas e melhoradas constantemente. Neste contexto existe a possibilidade das hipóteses do negócio serem divididas em pequenas hipóteses e, quando uma destas for dada como falsa, ocorrer uma mudança na direção da organização, fato intitulado como pivotação.

Segundo Blank (2012), o próximo conjunto de atividades inclui o desenvolvimento de testes para ver se o modelo de negócios resultante é repetível e escalável e, em caso negativo, volta-se para a etapa anterior. Então deve ser realizado o teste de vendas para determinar se existe um produto forte o suficiente 
para justificar a escala e os gastos de Marketing. Uma falha comum das startups é o escalonamento prematuro e para evitar este escalonamento prematuro é preciso:

1 - Estudar e determinar a posição do produto, do material de Marketing a ser utilizado, do canal de distribuição, além de desenhar um roadmap de vendas, criar um conselho e preparar o time para "ir para a rua".

2 - Tirar os fundadores do prédio para realizar os testes, sendo mais importante obter feedbacks do que realizar as vendas.

3 - Já com informações suficientes dos consumidores é preciso desenvolver o refinamento do produto e da proposta de valor da empresa. 4 - Finalmente é preciso parar tudo para analisar se é o momento de remodelar ou progredir, sendo feitas análises e verificações detalhadas. É preciso verificar se o negócio esta valendo a pena, se gera renda e crescimentos suficientes, conforme seus objetivos. É o momento em que deve-se integrar as últimas versões com as hipóteses e atualizar o Business Model Canvas (BMC), abordagem que será melhor detalhada na continuidade deste estudo.

Para Blank (2012), a chave é olhar as interações e interseções ao longo do $\mathrm{BMC}$, consistindo numa longa jornada onde as hipóteses devem ser transformadas em descobertas sobre os consumidores e então em fatos. Com os múltiplos testes que foram conduzidos no processo de validação é possível saber se é o momento de dar continuidade ou não ao negócio e, se for o caso, deve-se rever o modelo e voltar, redesenhar e desenvolver novos testes (BLANK, 2012).

Ainda segundo Ries (2011), neste momento é preciso verificar se existe demanda e quanto os consumidores estão disposto a pagar pelo produto, buscando a certeza de que o resultado será um negócio rentável, analisando a decisão de pivotar ou manter o percursso original. Segundo Blank (2012), neste momento algumas perguntas devem ser respondidas tendo em vista entender o problema do consumidor e ver se a proposta de solução fará com que o consumidor compre ou use o produto baseado no que é mais importante. Estas perguntas incluem:

- Foi identificado um problema que o consumidor deseja resolver?

- O produto resolve o problema ou necessidade?

- Existe um plano de negócios viável e rentável?

- Já se aprendeu o suficiente para iniciar as vendas? 
- Quando serão transformadas em fatos as hipóteses dos fundadores?

Segundo Ries (2011), o processo de aprendizagem validado no Lean Startup é uma sistêmica capaz de conduzir experimentos, onde deve-se especificar o problema, estabelecer hipóteses e testes que serão utilizados para validá-los ou não, definindo métricas que permitam verificar o que foi aprendido. A Figura 11 apresenta esquematicamente este ciclo de aprendizagem.

Figura 11: Looping de aprendizado do Lean Startup

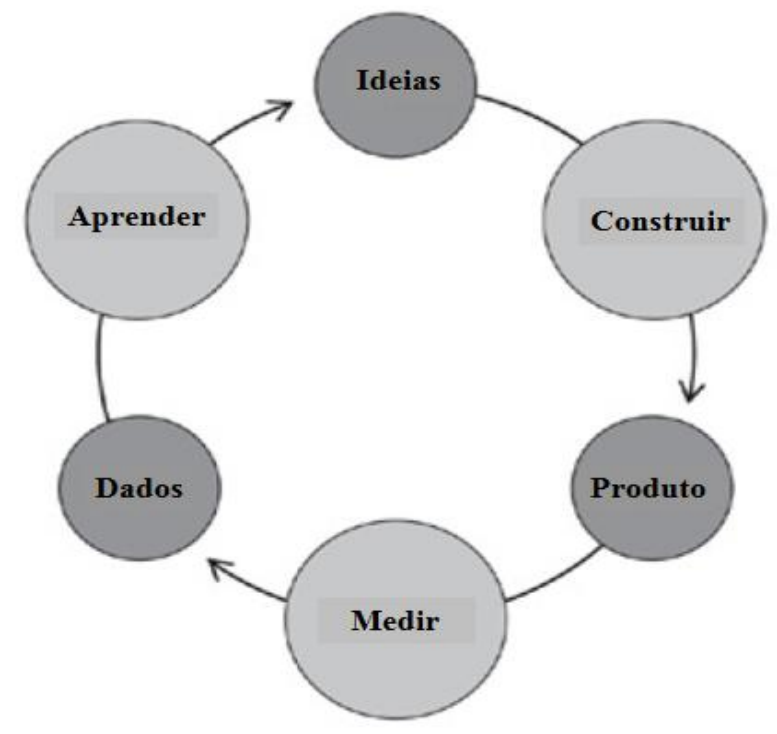

Fonte: RIES, E. (2011, p. 81).

Ries (2011) defende a ideia de que as etapas isoladas não possuem valor e o objetivo é reduzir ao minimo possível o tempo do giro no looping da Figura 11, sendo um método eficiente para identificar o que testar primeiro, dispendendo menos tempo e dinheiro no processo de desenvolvimento de um novo produto ou serviço. Neste momento surge o termo "Afinação da Engenharia", utilizado por Ries (2011) para descrever o processo de otimização constante.

Resumindo a proposta de Blank temos a primeira etapa de "Descoberta do Consumidor", onde é preciso identificar os segmentos de consumidores e como estes avaliam o problema que o serviço ou produto proposto busca solucionar; na segunda etapa, "Validação do Consumidor", existe a tentativa de provar que existe mercado para o serviço ou produto proposto; num terceiro momento, "Criação de Consumidor" o foco é escalonar o mercado com a criação e direcionamento da demanda dos consumidores e finalizando, temos a transformação da startup de uma 
organização de aprendizagem e descoberta em um efetivo negócio em execução, "Criação da Organização" (JÄRVI; TAAJAMAA; HYRYNSALMI, 2015).

\subsubsection{Métricas do Lean Startup}

Para Blank (2012), as métricas das startups são diferentes das métricas das grandes organizações, sendo um tópico que merece atenção. Para Ries (2011), a mensuração no Lean Startup baseia-se no aprendizado validado, uma unidade de progresso que inclui uma forma de trabalho diferenciada, que às vezes produz algo que não é útil porém contribui na descoberta da "coisa certa" a ser produzida. $\mathrm{Na}$ fase de mensuração o maior desafio é determinar quando os esforços para o desenvolvimento do produto estão levando a um progresso real (RIES, 2011).

Como métricas de utilização, Ries (2011) destaca a Análise Cohort enquanto uma das mais importantes análises para as startups, sendo uma premissa básica de que no lugar de se olhar o total cumulativo dos grupos, deve-se olhar para a performance individual de cada grupo de consumidores que entra em contato com 0 produto, onde cada grupo é chamado de Cohort (RIES, 2011). Outro experimento importante, segundo o autor, é o Split-Test, no qual diferentes versões de um produto são oferecidas ao consumidor ao mesmo tempo e então oberva-se o comportamento de cada grupo de consumidor.

De acordo com Ries (2011), as méticas de valor devem ser:

- Acionáveis - demonstrar claramente relações de causa e efeito, pois assim as pessoas estão melhor habilitadas para aprender com o fruto de suas ações.

- Acessíveis - gerar relatórios de simples entendimento, de forma a torná-los compreensiveis, utilizando unidades concretas e tangíveis, com informações acessíveis para todos os interessados.

- Auditáveis - os relatórios necessitam ser auditavéis para que se saiba se estão fornecendo informações reais.

Croll e Yoskovitz (2013) consideram que a Lean Startup é um bom caminho para construir negócios e as métricas funcionam de forma a assegurar que os dados adequados serão coletados e analisados. Ainda segundo os autores, as métricas são importantes por estarem relacionadas ao modelo de negócios, deixando claros pontos como a proveniência do dinheiro, quanto custam as coisas, quantos 
consumidores a organização possui e qual a efetividade da estratégia de aquisição de clientes. Nos cenários de uma startup as métricas devem ser analisadas para que sejam encontrados produtos certos e o caminho para o mercado antes que os recursos disponíveis acabem (CROLL; YOSKOVITZ, 2013).

Croll e Yoskovitz (2013) defendem o conceito de One Metric That Matters (OMTM), que consiste no foco em uma única métrica considerada como extremamente importante para a startup naquele momento, permitindo o foco concentrado de toda a startup e a inspiração da cultura da experimentação. Para os autores boas métricas ajudam a predizer o futuro, dando a oportunidade para que os problemas sejam antecipados e corrigidos. Os autores também afirmam que diferentes tipos de organizações possuem diferentes métricas (CROLL; YOSKOVITZ, 2013), podendo variar desde taxa de conversão (o número de visitantes que efetivamente compram algo) até receita por consumidor (o valor do tempo de vida de cada consumidor).

Uma vez incorporada a definição de Empreendedorismo baseada fundamentalmente na abordagem da Lean Startup, surge a necessidade de uma ilustração que permita a visualização da organização que será construída e para tal cabe destacar o Business Model Canvas.

\subsection{Modelos de Negócios}

O processo de iniciar um novo empreendimento é marcado pela complexidade, principalmente nos primeiros estágios, quando o foco é o desenvolvimento de um produto ou serviço comercializável; neste contexto é de grande relevância a estruturação de um modelo de negócios para estabelecer melhor a proposta do novo empreendimento (TRIMI; BERBEGAL-MIRABENT, 2012). Ainda segundo os autores, é esperado que os modelos de negócios forneçam informações que auxiliem os empreendedores a tomarem decisões com maiores chances de sucesso, além de ser esperado que forneçam ferramentas para experimentação e testes de novas oportunidades.

O modelo de negócios estruturado também deve evidenciar o que deve ser feito para potencializar o valor entregue aos consumidores, além de permitir a visualização de como a organização deve ser gerida e quais os investimentos exigidos para viabilizar sua sustentabilidade, auxiliando no entendimento do negócio 
e na tomada de decisões, focando em inovação para conquistar a maturidade e o entendimento da entrega de valor positivo às partes interessadas (ABRAHAM, 2013; BOCKEN et al., 2013; TRIMI; BERBEGAL-MIRABENT, 2012).

Segundo Zott, Amit e Massa (2011), existem definições distintas para o termo modelo de negócios, que têm evoluído enquanto nova unidade de análise, além viabilizar uma abordagem holística, capaz de explicar como as organizações fazem seus negócios, as suas atividades principais e as regras importantes para as conceituações dos modelos de negócios propostos. Bonazzi e Zilber (2014) sintetizam algumas definições de modelo de negócios no Quadro 3:

Quadro 3: Definição de Modelos de Negócio

\begin{tabular}{l|c|l}
\hline Autor & Ano & \multicolumn{1}{c}{ Definiçáo de modelo de negócio } \\
\hline Timmers & 1998 & $\begin{array}{l}\text { Arquitetura para os fluxos de produtos e serviços incluindo uma descriçáo das ativida- } \\
\text { des do negócio e de suas fontes de renda. }\end{array}$ \\
\hline Stewart e Zhao & 2000 & Forma como a empresa visa obter lucros e sustentá-los ao longo do tempo. \\
\hline Amit e Zott & 2001 & Estrutura elaborada para a criaçáo de valor. \\
\hline Plé, Lecocq e Angot & 2008 & $\begin{array}{l}\text { Escolhas realizadas por uma empresa para gerar lucro. Englobam recursos e competên- } \\
\text { cias para criar valor, por meio de produtos operacionalizados pela empresa, interna ou } \\
\text { externamente. }\end{array}$ \\
\hline Casadesus-Masanell e Ricart & 2010 & Maneira como a organizaçáo cria e entrega valor aos seus stakeholders. \\
\hline Osterwalder e Pigneur & 2010 & Lógica de criaçáo, entrega e captura de valor por parte de uma organizaçáo. \\
\hline Zott, Amit e Massa & 2011 & Maneira como uma empresa faz negócio e como cria valor. \\
\hline Nielsen e Lund & 2012 & $\begin{array}{l}\text { Coerência das escolhas estratégicas da empresa, as quais tornam possíveis as relaçóes } \\
\text { para criar valor nos seus níveis operacional, tático e estratégico. }\end{array}$ \\
\hline
\end{tabular}

Fonte: BONAZZI, F. L. Z.; ZILBER, M. A. (2014, p. 620).

Para Casadesus-Masanell e Ricart (2010), os modelos de negócios representam a lógica de criação de valor das organizações, ou seja, a forma como a organização opera e cria valor para as partes interessadas, refletindo a abordagem estratégica selecionada para a organização. Ainda segundo os autores, o desenvolvimento de um modelo de negócios completo pode ser um processo complexo, requerendo uma quantidade elevada de trabalho e, por este motivo, algumas análises podem adotar representações simplificadas. Existem duas formas de facilitar o desenvolvimento de modelos de negócios completos e detalhados, a Agregação e a Decomposição. A Agregação parte de uma visão macro e detalha, com as escolhas conforme novos contextos demandando novas análises e decisões, já na Decomposição divide-se o modelo de negócios em diferentes conjuntos de 
escolhas e consequências, que não interagem entre si e que então podem ser analisados isoladamente.

Já para Timmers (1998), os modelos de negócio estabelecem arquiteturas de processos, serviços e fluxos de informações, incluindo a descrição de vários atores ligados ao negócio e suas regras, descrevendo os seus benefícios potenciais e a rentabilidade dos recursos. Ainda segundo o autor, apenas a definição do modelo de negócios não viabiliza o entendimento de como será a sua contribuição para o alcance da missão da organização. Para Casadesus-Masanell e Ricart (2010), todas as organizações adotam um modelo de negócios, já que cada organização faz suas escolhas e estas geram consequências, logo os modelos de negócios refletem a estratégia organizacional implementada.

Amit e Zott (2001) propõe a ideia de que o modelo de negócios é um importante catalisador da inovação e um recurso fundamental para a criação de valor, tanto para a organização como para seus fornecedores, clientes e parceiros. Os modelos de negócios permitem que as escolas de estratégia, gestão e empreendedorismo enderecem um único conjunto de questões que viabilizam a criação de valor (AMIT; ZOTT, 2001). Ainda segundo os autores, o modelo de negócios retrata o desenho do conteúdo das transações, estruturas e governança, criando valor para a exploração das oportunidades de negócios. Estas transações relacionam-se com:

- Conteúdos - relacionados a bens e informações que podem ser trocados, englobando também os recursos e capacidades que são requeridos para a mudança.

- Estruturas - inclui as partes que participam da mudança e a forma como estas partes são conectadas, influenciando a flexibilidade, adaptação e escalabilidade das transações atuais.

- Governança - refere-se ao caminho das informações, recursos e bens, controlados pelas partes relevantes, contando com o formato legal da organização, além dos incentivos governamentais que esta eventualmente possa dispor.

Pré, Lecocq e Angot (2010) consideram que a participação dos consumidores nos modelos de negócios ainda é pouco estudada e subestimada e, em muitos contextos, os consumidores são considerados como meros compradores. Ainda 
segundo os autores, o modelo de negócios explora o processo de geração de recursos e assim identifica a lucratividade, que pode assumir formas diversas, relacionadas com o uso dos recursos pelas organizações.

Abraham (2013) considera que a abordagem dos modelos de negócios pode ser utilizada para a formulação de uma análise SWOT (Strengths, Weaknesses, Opportunities, Threats) completa da organização. lacob et al. (2012) defendem que primeiramente o modelo de negócios deve ser explicitamente construído e analisado antes de qualquer implementação, sendo necessário para isso a adoção de uma abordagem capaz de relacionar a arquitetura do empreendimento e seus modelos de negócios. Assim, estas abordagens possuem como função descrever racionalmente como uma organização cria, captura e entrega valor e, neste contexto, destaca-se a abordagem do Business Model Canvas (OSTERWALDER; PIGNEUR, 2010).

\subsubsection{Business Model Canvas}

Para Martikainen, Niemi e Pekkanen (2013), Bocken et al. (2013), lacob et al. (2012), Gelbmann e Hammerl (2014), Nielsen e Montemari (2012), Trimi e BerbegalMirabent (2012) e Sleuwaegen (2013) o Business Canvas Model é um framework útil para estabelecer análises graças à sua representação esquemática sobre como um negócio pode operar para criar valor com foco nos seus consumidores, mostrando como será este relacionamento e estabelecendo a lógica dos negócios. Desta forma, permite a identificação dos pontos chave para entregar valor superior aos consumidores e estabelecer vantagem competitiva para a organização. Para Chen, Cheng e Mehta (2013), com a adoção deste modelo é possível entender a criação de valor e as operações em diferentes contextos, algo de importância especial para países ainda em desenvolvimento, onde existem custos associados com tempo e viagens para avaliação de conveniência ao acesso. Segundo Cabanelas, Omil e Vázquez (2013), é desenhado para estabelecer metas de negócios em hierarquias convencionais de organizações, sendo uma abordagem de entrega de valor com origem nas competências internas e também em consumidores chave e competidores.

Segundo Osterwalder e Pigneur (2010), Banchieri, Blasco e Campa-Planas (2013) e Martikainen, Niemi e Pekkanen (2013), sua linguagem permite a fácil 
descrição e manipulação dos modelos de negócios, funcionando como um sintetizador da lógica da organização, capaz de sinalizar os pontos essenciais, apresentando apenas os conceitos necessários a realização dos primeiros passos; funcionando como um manual de ajuda para a organização, facilitando inclusive a criação de novas alternativas estratégicas. A abordagem também permite que a organização obtenha uma visualização gráfica da sua lógica de negócios, evidenciando a relação entre os elementos e viabilizando a reflexão constante graças à visualização de como o negócio articula-se em diferentes áreas. A estrutura formada por claras categorias que focam na relação entre os atores auxilia no processo de tomada de decisões, destacando os assuntos, conceitos e as suas relações, expressando a lógica dos negócios e permitindo o melhor entendimento dos fatores chave que devem determinar a estratégia organizacional (AXELSSON; PAPATHEOCHAROUS; ANDERSSON, 2014; BANCHIERI; BLASCO; CAMPAPLANAS, 2013; TRIMI; BERBEGAL-MIRABENT, 2012).

Quanto ao seu formato, sua forma gráfica auxilia na identificação de riscos e falhas, apresentando layout que aumenta a criatividade organizacional, sendo incorporado às dinâmicas de Design Thinking, apresentando o formato apropriado para a realização de brainstorming de negócios, priorizando por onde começar e qual o aprendizado efetivo, com o objetivo de tirar uma foto do modelo de negócios atual da organização (MAURYA, 2012; BOCKEN et al., 2013).

Segundo Maurya (2012) e Banchieri, Blasco e Campa-Planas (2013), o Business Model Canvas é um modelo de validação que ajuda a documentar o plano de negócios, mensurar o progresso e comunicar o aprendizado para as partes interessadas, internas e externas, tratando-se de um framework popular para dar suporte aos processos genéricos de identificação e desenvolvimento de modelos de negócio. É representado graficamente numa única folha, o que facilita o seu uso como ferramenta de gestão estratégica, estabelecendo uma visão holística da organização. Para Banchieri, Blasco e Campa-Planas (2013), o modelo é útil para definição de negócios e não para a implementação de estratégia, mas no complexo cenário atual é válido obter uma visão das inter-relações entre as diferentes áreas de gestão que sustentam o negócio. Ainda segundo estes autores, o modelo gera conhecimento facilitador do processo de tomada de decisão, competência fundamental para a sobrevivência das organizações. Para Abraham (2013), viabiliza 
análises estratégicas que permitem à organização entender o cenário no qual está inserida, ajudando esta a encontrar formas que a auxiliem a ser mais competitiva.

Para lacob et al. (2012), o Business Model Canvas auxilia na implementação das decisões aconselháveis para novos projetos de inovação e para a consolidação das solicitações de negócios. Segundo Wittel e Löfgren (2013), o modelo apresenta uma estrutura inovadora em termos de representação de modelos de negócio, conectando as atividades de forma a mostrar como as mudanças na prática. Para Gelbmann e Hammerl (2014), o modelo é um facilitador de inovações radicais por seu template atual e popular para o desenvolvimento de modelos de negócio.

Para Axelsson, Papatheocharous e Andersson (2014) e Martikainen, Niemi e Pekkanen (2013), o modelo também é utilizado por viabilizar uma metodologia para análises de negócios já estabelecidos, sintetizando informações suficientes para orientar e assegurar que o potencial do negócio foi analisado por diferentes perspectivas, incluindo todas as áreas organizacionais que devem ser atendidas no momento da estruturação do modelo.

Para Martikainen, Niemi e Pekkanen (2013), é uma ferramenta de implementação e requer análises financeiras e estratégicas complementares. Cherif e Grant (2013) mencionam que o modelo considera apenas as questões ligadas aos consumidores e infraestrutura do negócio. Para Bocken et al. (2013) apresenta limitações, como várias outras ferramentas utilizadas na avaliação de inovações. E para Martikainen, Niemi e Pekkanen (2013), o modelo vem sendo criticado por não considerar todas as áreas da organização. É fato que, apesar do modelo ser amigável para o desenho de processos, este não captura as mudanças estratégicas organizacionais, sendo necessário representar também a sua evolução (SINKOVICS; SINKOVICS; YASMIN,2014).

\subsubsection{Estrutura do Business Model Canvas}

Osterwalder e Pigneur (2010) são os criadores da abordagem Business Model Canvas e dividem a análise em nove blocos, que buscam mostrar como a organização vai gerar retorno financeiro, funcionando como um blueprint estratégico para a implementação de estrutura organizacional, processos e sistemas, conforme Figura 12. Para Yen, Drinka e Kanamori (2013), cada um dos nove blocos pode ser diretamente traduzido em um conjunto de hipóteses de descoberta do consumidor, 
pois a abordagem, quando é proposta em conjunto com o desenvolvimento do consumidor, tem seu layout dinamizado e o desenvolvimento transformado em estratégico. Para Cherif e Grant (2013), representa a lógica de como uma organização faz dinheiro. E segundo Nielsen e Montemari (2012), explicita as competências organizacionais. Segundo Axelsson, Papatheocharous e Andersson, (2014) as principais informações dos modelos de negócios podem ser encontradas nas categorias de Proposições de Valor, Fontes de Receitas e Estrutura de Custos.

Figura 12: Business Model Canvas

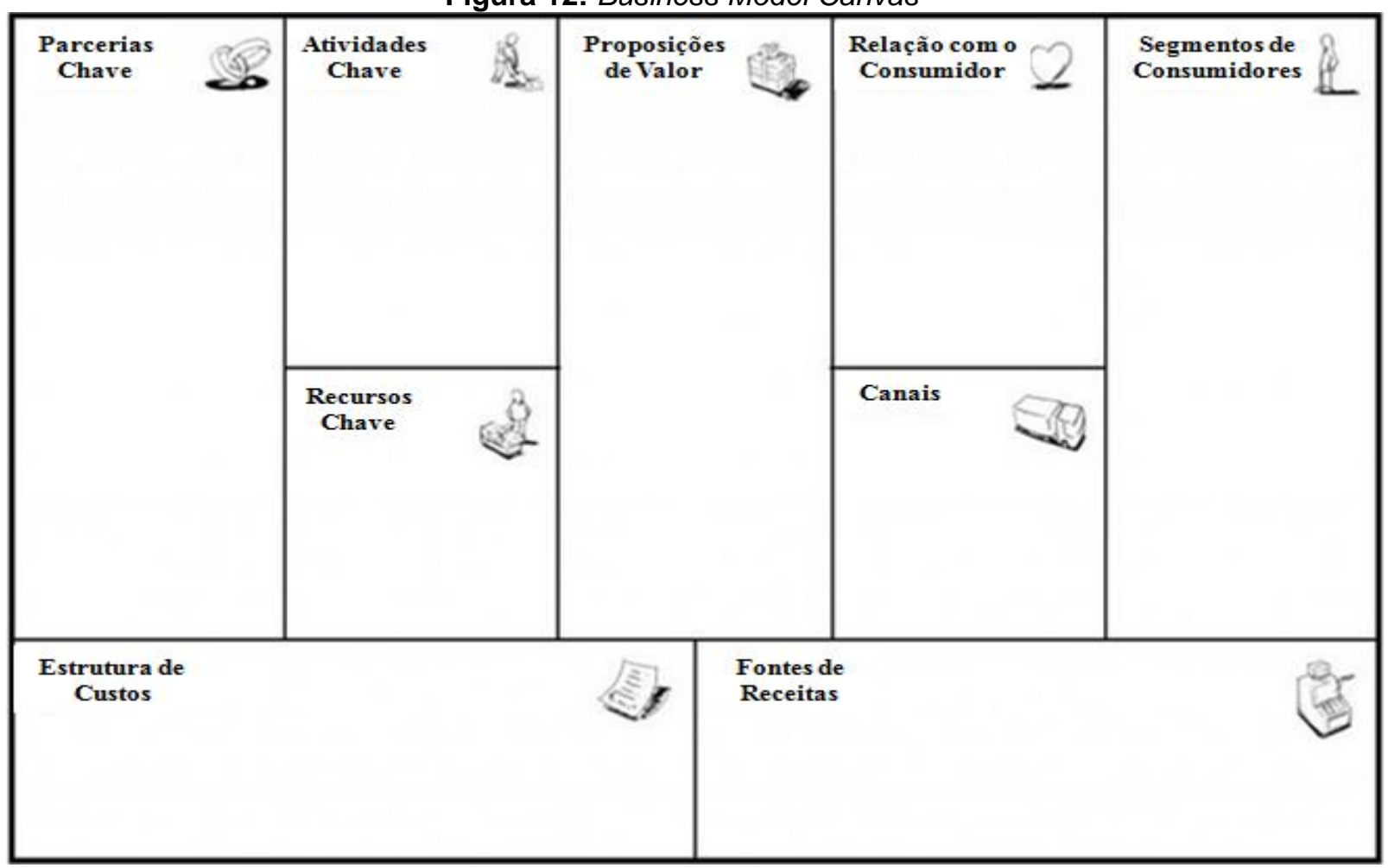

Fonte: Adaptado OSTERWALDER, A.; PIGNEUR, Y. (2010, p. 44).

Os nove blocos propostos por Osterwalder e Pigneur (2010) são:

- Segmentos de Consumidores - os consumidores são agrupados de acordo com suas necessidades e desejos comuns, permitindo que a organização priorize quais segmentos atender. É o momento em que é determinado quem receberá as entregas de valor. Axelsson, Papatheocharous e Andersson (2014) mencionam que é quando a empresa define os diferentes grupos de pessoas e organizações que deseja servir e alcançar, além de identificar os consumidores mais significantes para a produção de valor. 
- Proposições de Valor - consiste num conjunto de produtos e serviços que a organização irá ofertar para os segmentos de consumidores priorizados, com o objetivo de satisfazer suas necessidades. É o diferencial da organização, são os problemas que a empresa busca resolver para garantir a satisfação dos clientes. Para Axelsson, Papatheocharous e Andersson (2014) é o momento em que são identificados os serviços ou produtos que criam valor para determinado grupo de consumidores, discutindo-se inclusive quais são as qualidades e atributos mais importantes.

- Canais - inclui os canais de vendas, distribuição e comunicação, ou seja, a forma pela qual a organização se comunica para entregar valor aos segmentos de consumidores priorizados. Inclui pontos de contato com o consumidor desde o início da relação de compra até a avaliação do valor entregue, sendo a proposta de valor entregue pela organização por meios diversos. Para Axelsson, Papatheocharous e Andersson (2014), é como a organização alcança e comunica aos consumidores o seu valor, existem quatro tipos de canais distintos: Canais de Vendas, Canais de Distribuição, Configurações dos Canais e Canais de Informações.

- Relação com o Consumidor - neste bloco a organização deve deixar clara qual o tipo de relação que pretende desenvolver com os segmentos de consumidores priorizados, detalhando as relações de consumo que serão estabelecidas e mantidas. Segundo Axelsson, Papatheocharous e Andersson (2014), cabe lembrar que a conectividade atual permite novas possibilidades na construção de relação entre as organizações e seus consumidores.

- Fontes de Receitas - representa o rendimento obtido com cada segmento de consumidores, considerando que cada um terá o seu preço, volume e gestão. Para Axelsson, Papatheocharous e Andersson (2014), são as receitas geradas por cada grupo de consumidores, valendo mencionar que existem diferentes maneiras de gerar receita.

- Recursos Chave - representa os recursos mais importantes que a organização deve dispor para fazer com que o modelo de negócios funcione. São os recursos que permitem à organização criar valor, 
podendo ser intelectuais, físicos, financeiros ou mesmo humanos. Podem ser próprios da organização ou ser adquiridos junto aos parceiros principais. Axelsson, Papatheocharous e Andersson (2014) declaram que não devendo-se esquecer dos recursos intelectuais.

- Atividades Chave - são os processos mais importantes que devem ser executados para que o modelo de negócios funcione, é o que precisa ser desenvolvido afim de que a empresa possa oferecer e entregar valor. Criam valor de forma a manter a organização rentável e os consumidores fidelizados. Segundo Axelsson, Papatheocharous e Andersson (2014), são os itens mais importantes que a organização deve produzir para fazer com que o seu modelo de negócios funcione, incluindo os produtos, desenvolvimento, integração, entrega e manutenção.

- Parcerias Chave - trata da relação com os parceiros que auxiliam a organização no seu funcionamento perfeito. A criação de alianças que permitem que recursos sejam adquiridos, riscos sejam reduzidos e 0 modelo de negócios seja otimizado, para que assim a organização possa ofertar e entregar valor aos seus clientes. Axelsson, Papatheocharous e Andersson (2014) declaram como a rede de parceiros e fornecedores que permitem que o modelo de negócios funcione.

- Estrutura de Custos - representa todos os custos da organização, detalhando os custos de cada bloco do modelo de negócios, sendo os custos da estrutura organizacional. Segundo Axelsson, Papatheocharous e Andersson (2014), são todos os custos envolvidos para que o modelo de negócios possa operar, podendo englobar o Desenvolvimento de Custos e os Custos de Produção, Operação e Informação.

Segundo Trimi e Berbegal-Mirabent (2012), os blocos podem ser simplificados em macro-blocos:

- Atividades Chave - os produtos e serviços que serão entregues.

- Segmentos de Consumidores, Proposições de Valor e Relação com - Consumidor - relacionamento com o consumidores foco da organização, incluindo itens como demanda e formas de entregar valor.

- Parcerias Chave, Recursos Chave e Canais - relação com parceiros e as funções de produção e logística. 
- Estrutura de Custos e Fonte de Receitas - estrutura de custos e sustentabilidade da organização, demonstrando as formas de geração de retorno.

Em linha com este pensamento de redução e simplificação do Business Model Canvas Banchieri, Blasco e Campa-Planas (2013) desenvolveram perguntas que servem como mecanismos para simplificar o preenchimento do modelo, em que cada macro-bloco possui um questionamento específico, capaz de facilitar o seu preenchimento e entendimento por parte do empreendedor:

- Atividades Chave - Como?

- Relação com o Consumidor, Canais e Segmentos de Consumidores - Quem?

- Proposições de Valor - O quê?

- Estrutura de Custos e Fonte de Receitas - Quanto?

\subsubsection{Value Proposition Design}

Segundo Osterwalder et al. (2014), o Value Proposition Design surge como um trabalho complementar ao Business Model Canvas, apresentando os passos para o detalhamento de como a organização cria valor para o consumidor. A abordagem busca inventar novas proposições de valor, consistindo na proposição de algo que os consumidores desejam, além de identificar modelos de negócios que funcionem. O modelo proposto é apresentado na Figura 13.

Figura 13: Value Proposition Design

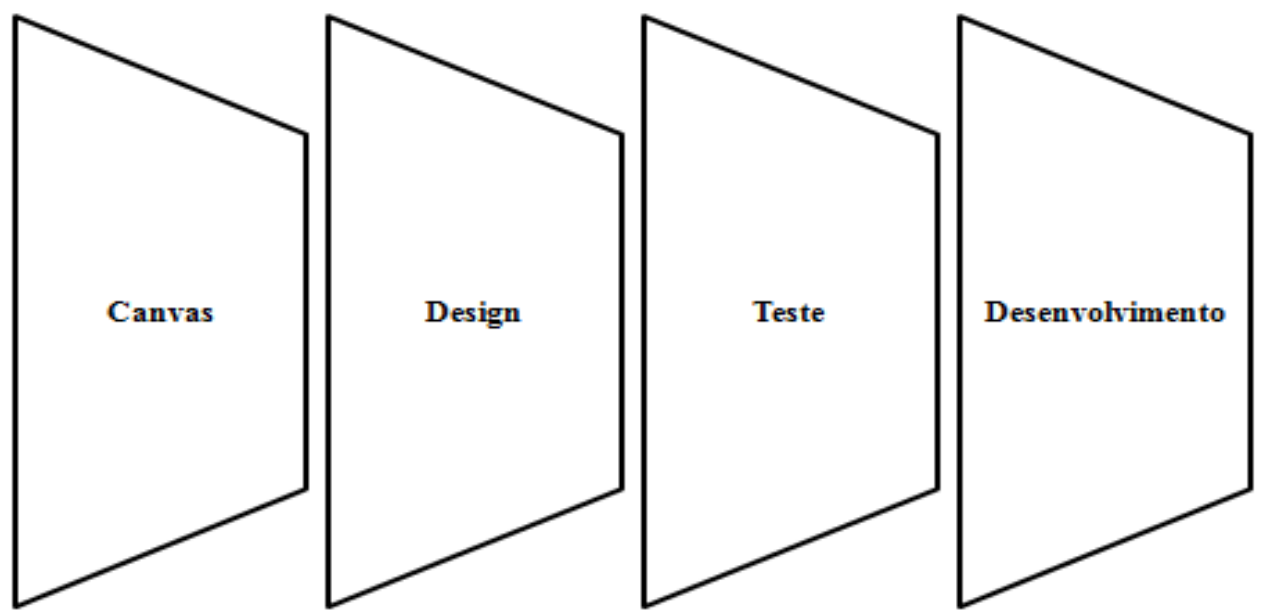

Fonte: Adaptado de OSTERWALDER, A.; PIGNEUR, Y; BERNARDA, G.; SMITH, A.; PAPADAKOS, T. (2014, p. 3 e 4). 
Detalhando a Figura 13 temos:

- Canvas - ilustrado pela Figura 14.

Figura 14: Canvas

Mapa de valor

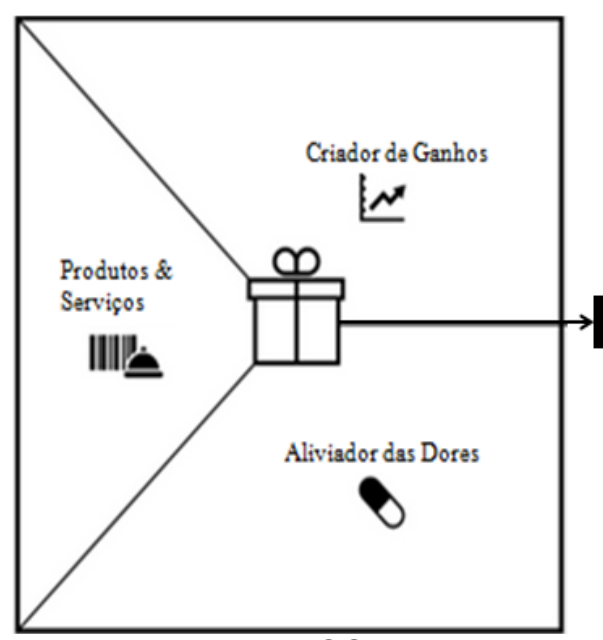

Fonte: Adaptado de OSTERWALDER, A.; PIGNEUR, Y; BERNARDA, G.; SMITH, A.; PAPADAKOS, T. (2014, p. 43).

Perfil do consumidor

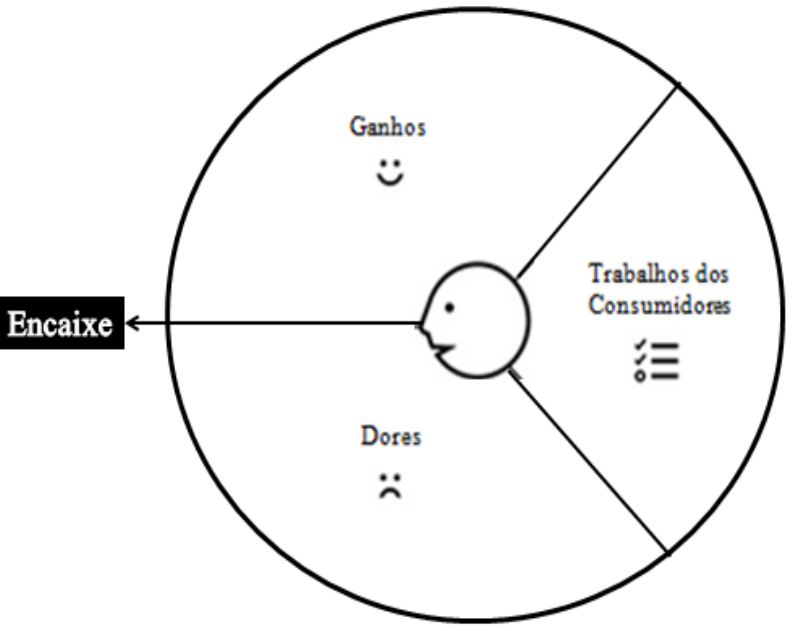

Consumidores

:=

Abordando a Figura 14 de forma detalhada:

- Perfil do Consumidor - consiste em compreender o consumidor de forma estruturada e detalhada, especificando o segmento que será atendido, suas características são desmembradas em:

- Trabalho do consumidor - o que os consumidores buscam fazer, ou seja, a necessidade que desejam ver atendida.

- Dores - são os resultados ruins, riscos e obstáculos relacionados com o trabalho do consumidor.

- Ganhos - descrevem os benefícios que os clientes desejam.

De forma a aliviar as dores do consumidor e potencializar seus ganhos a proposta de valor da startup deve definir:

- Mapa de Valor - descreve como a organização pretende criar valor para o consumidor. Divide a organização em: 
- Produtos e serviços - ofertados para auxiliar os consumidores a realizarem o trabalho priorizado anteriormente.

- Aliviador das dores - como seus produtos ou serviços irão aliviar as dores dos consumidores.

Criador de ganhos - como serão os ganhos dos consumidores com seu produto ou serviço.

- Encaixe - encontro do Perfil do Consumidor e Mapa de Valor, que ocorre quando o seu produto ou serviço alivia a dor do consumidor, trazendo a este algum ganho válido.

- Design - composto por:

- Prototipação das Possibilidades - prototipação que permite um início rápido do desenho da proposta de valor, desenhando rapidamente modelos de ideias que exploram as alternativas e dão forma à proposição de valor, buscando encontrar a melhor alternativa. O conceito de proposição de valor é aplicado rapidamente para a exploração das possibilidades que futuramente serão testadas e darão forma a um produto ou serviço real, juntamente aos modelos de protótipos propostos é levantado o Minimum Viable Product.

- Ponto de Início - com a prototipação tem-se os pontos iniciais.

- Entendimento do Consumidor - a proposição de valor deve ter a sua forma dada pelo Entendimento do Consumidor.

- Escolhas - é necessário escolher as ideias desejadas para exploração futura.

- Descoberta do Modelo de Negócios Correto - é preciso ainda encontrar o modelo de negócios correto, ideal.

- Designing em Organizações Estabelecidas - quando trata-se de uma organização já existente é necessário descobrir as suas particularidades.

- Teste - são válidos por reduzirem o risco e incertezas de suas ideias tanto para novidades como para melhoria da proposição de valor e são desmembrados em: 
- O que será Testado - decisão necessária e que a própria formulação dos testes irá indicar.

- Teste Passo-a-Passo - é necessário que os testes ocorram passo-apasso.

- Biblioteca Experimental - pode ser construída uma biblioteca com todos os experimentos realizados, facilitando a sua localização e também dos resultados obtidos.

- Junção de Tudo - tudo deve ser unido e o progresso deve ser mensurado.

- Desenvolvimento - segmentado em:

- Criação de Alinhamento - a proposta de utilizar do Business Model Canvas e o Value Proposition Design é compartilhar uma linguagem na busca pela criação de alinhamento, sendo necessário que todas as partes da organização continuem envolvidas.

- Mensurar \& Monitorar - é preciso ter certeza que o trabalho está sendo mensurado e monitorado constantemente, com o Business Model Canvas e o Value Proposition Design sendo acompanhados sempre.

- Melhorar Incansavelmente - com a mensuração e acompanhamento ainda é possível ter uma rotina incansável de melhoria.

- Reinvenção Constante de Si - a mensuração e acompanhamento ainda permitem que a organização seja reinventada constantemente.

Com a apresentação do Value Proposition Design finaliza-se a revisão bibliográfica deste estudo e, neste momento, tem início a apresentação do seu método de pesquisa, para que os objetivos do estudo sejam alcançados e este estudo possa chegar às respostas que correspondem aos objetivos propostos para esta pesquisa. 


\section{MÉTODO}

Atualmente parte significativa das inovações radicais são geradas por startups e neste contexto sua importância aumenta significativamente; porém, como evidenciado na revisão de literatura, verifica-se atualmente a falta de estudos específicos com foco em evitar ou ao menos minimizar a alta taxa de mortalidade verificada nos seus primeiros anos de funcionamento. Desta maneira, esta pesquisa tem por objetivo contribuir com o processo de estruturação de startups propondo um Framework Cíclico, que viabiliza a geração e o refinamento dos seus conceitos norteadores e a estruturação inicial de sua operação, por meio de uma representação fiel das fases e etapas relevantes, recomendadas e empregadas por especialistas e por empreendedores que constituíram startups de sucesso.

Este estudo apresenta caráter exploratório já que se insere nos primeiros estágios de uma pesquisa sobre um fenômeno recente, quando ainda se buscam conceitos, evidências e ideias preliminares relacionadas com os assuntos de interesse (nesta pesquisa Cadeia de Valor da Inovação, Design Thinking, Lean Startup e Business Model Canvas). Segundo Forza (2002), pesquisas exploratórias ocorrem quando o conhecimento sobre o fenômeno ainda não foi articulado numa fórmula teórica com conceitos, modelos e proposições bem definidos.

Ainda de acordo com Forza (2002), os testes relacionados com a estruturação de novas teorias obtidas em pesquisas envolvem um longo processo, que pressupõe a estruturação de um modelo teórico, capaz de ofertar uma identificação dos conceitos relevantes para a pesquisa em andamento que seja claro e bem definido. Assim, após a revisão de literatura, este estudo caminhou para o desenvolvimento de uma primeira versão do Framework Cíclico, baseado na revisão de literatura e com a preocupação de detalhar as fases e etapas propostas, esclarecendo suas relações.

De acordo com Forza (2002), com o modelo teórico estruturado devem ser construídas as relações e definidas as suas condições de aplicação, além dos indicadores de validação. Ainda segundo o autor, antes da pesquisa iniciar a efetiva coleta de dados é preciso definir a sua unidade de análise, que deve corresponder às análises realizadas em relação à teoria, de forma a prover um teste para as definições operacionais e assim a tradução das proposições em hipóteses. 
Neste momento vale retomar as questões e o objetivo principal deste estudo, construir um Framework Cíclico que represente as relevantes e efetivas fases e etapas empregadas e recomendadas por empreendedores de startups de sucesso no processo de geração e refinamento de conceitos e na estruturação inicial da operação. Para isto buscou-se responder as seguintes indagações:

- Existem fases e etapas que os empreendedores de sucesso recomendam para a estruturação de uma startup de sucesso? Se sim, quais?

- Considerando o Framework Cíclico proposto, quais fases e etapas são consideradas como efetivamente relevantes na constituição de uma startup de sucesso? E quais são menos relevantes ou irrelevantes?

- As startups de sucesso respondentes desta pesquisa utilizaram parte significativa das fases e etapas propostas pelo Framework Cíclico em sua busca por obter sucesso?

- Qual o perfil dos empreendedores das startups de sucesso?

Com o primeiro desenho do Framework Cíclico em mãos e os resultados da apresentação deste a dois empreendedores de sucesso, foi realizado o exame de qualificação buscando avaliar sua coerência e relevância. Como resultado a banca sugeriu recomendações, pontos de ajuste ao longo do texto, rever a justificativa do estudo, o nome e o layout do Framework Cíclico e apresentar o resultado para especialistas ligados à startups tendo em vista aprimorando do Framework com suas sugestões e recomendações.

Assim, considerando as recomendações da banca de qualificação foi elaborada a segunda versão do Framework Cíclico. Esta nova versão foi apresentada num painel de especialistas ligados à startups e as respostas obtidas foram analisadas utilizando a técnica de Análise Qualitativa, selecionada por sua reconhecida utilização para a explicação de experiências diretas, do cotidiano em relação a determinados assuntos (DENZIN; LINCOLN, 1994). A Análise Qualitativa, quando apoiada com o uso de computador, como foi realizado nesta pesquisa, permite o desenvolvimento de uma análise de dados compreensível, exaustiva e sistemática (GEPHAT; ROBERT, 2004).

A validação qualitativa junto aos especialistas resultou em conhecimentos relevantes para aprimorar o Framework Cíclico, dando origem à sua terceira versão. Como o conjunto de especialistas consultado validou o Framework e o considerou 
bastante relevante de forma geral, a pesquisa retomou seu objetivo original, aplicar uma survey junto à empreendedores de startups de sucesso tendo em vista verificar quais as fases e etapas do referencial efetivamente utilizadas e consideradas relevantes e recomendadas. Para a análise dos dados foram empregadas as técnicas de Análise Qualitativa, pelos mesmos motivos que foram empregada junto ao Painel de Especialistas e Análise Fatorial pela sua reconhecida capacidade de generalizar o conhecimento racional (WILL; FRANSOO, 2002) e para possibilitar a validação do conjunto de etapas proposto a cada fase do Framework.

Em suma, o método aplicado nesta pesquisa consistiu em quatro etapas:

1 - Ampla revisão bibliográfica dos assuntos de interesse: Cadeia de Valor da Inovação, Design Thinking, Lean Startup e Business Model Canvas, apresentada no Capítulo 2, resultando na primeira versão do Framework Cíclico, validada e aprimorada com a realização de dois estudos de caso.

2 - Aprimoramentos a partir do exame de qualificação, originando a segunda versão do Framework.

3 - Apresentação do Framework proposto junto a um painel de especialistas, utilizando questionários estruturados, tendo em vista a sua validação e aprimoramento, resultando na terceira versão do Framework Cíclico.

4 - Validação e aprimoramento da terceira versão do Framework Cíclico com a aplicação de survey junto à empreendedores de startups de sucesso, capaz de identificar as principais práticas executadas, resultando na quarta e final versão do Framework.

A seguir serão apresentados os fundamentos dos métodos de pesquisa empregados neste estudo: Revisão Bibliográfica, Painel de Especialistas e Survey.

\subsection{Revisão Bibliográfica}

Para Boote e Beile (2005), uma revisão bibliográfica funciona como o ponto de partida, a fundação de uma pesquisa a ser desenvolvida, é o momento em que são buscados objetivos tais como desenhar o contexto e os limites do estudo futuro, sendo o fundamento para alcançar uma pesquisa substancial e útil. Ainda segundo os autores, a condução da revisão bibliográfica é a demonstração do conhecimento do autor a respeito de um assunto, além de evidenciar as suas influências, informando quais são as outras pesquisas e grupos da área de interesse. 
Boote e Beile (2005) defendem que para escrever uma revisão bibliográfica significativa é preciso começar com a leitura de diferentes teorias, pois é esta leitura que permite a identificação da literatura relevante para a pesquisa. Uma vez que se sabe a relevância torna-se possível definir quais são as teorias fracas e quais são as teorias fortes, onde a força de uma teoria depende do quanto esta se mostra interessante (SUTTON; STAW, 1995). Por sua vez Eisenhardt (1989) defende a ideia de que o desenvolvimento da revisão bibliográfica é a atividade central em pesquisas organizacionais, em que se combina literatura prévia, senso comum e experiência.

Para Webster e Watson (2002), uma característica essencial para qualquer projeto acadêmico é uma leitura relevante, podendo o avanço do conhecimento ser alcançado por uma revisão bibliográfica efetiva. Para tal, cabe a identificação das leituras relevantes, que não devem se limitar apenas a um tipo de pesquisa ou conjunto de periódicos, pois desta forma não seria completa nem relevante, devendo sempre considerar diferentes pontos de vista. Ainda segundo os autores é papel da própria revisão bibliográfica mostrar ao leitor o que está sendo apreendido, evidenciando padrões identificados na literatura disponível em relação ao assunto de interesse. Daft (1985) destaca que no processo de revisão bibliográfica é relevante evidenciar como os autores das obras analisadas conseguiram chegar aos resultados obtidos.

Para Brereton et al. (2007), quando o assunto é a revisão bibliográfica o seu ponto mais crítico é a especificação da questão de pesquisa do estudo a ser desenvolvido. Miguel (2010) defende a ideia de uma abordagem estruturada, que viabilize certa liberdade, permitindo que o pesquisador altere os limites de sua pesquisa científica e até mesmo a sua forma de condução sempre que considerar válido para alcançar o objetivo da pesquisa da melhor forma possível. Quanto às atividades para o desenvolvimento da revisão bibliográfica, Miguel (2010) acredita que inicialmente é preciso definir o referencial conceitual teórico a ser empregado na pesquisa que será desenvolvida, consistindo num mapeamento da literatura a respeito do assunto, evidenciando como o tópico que foi selecionado para a pesquisa recebe influencia das bibliografias existentes.

Brereton et al. (2007) afirmam que para elaborar uma revisão bibliográfica relevante cabe o desenvolvimento mandatório de algumas atividades, que podem ser objetivamente agrupadas em três iniciativas: planejar, conduzir e reportar as 
revisões. Demo (2000) defende duas contribuições principais da revisão de literatura: a elaboração das hipóteses e proposições e o fornecimento de subsídios para os futuros argumentos que serão sustentados ou refutados durante a fase de análise. Para Miguel (2009), a revisão bibliográfica possuí o papel de delimitar as fronteiras do que será investigado, de forma a fornecer o suporte teórico para a pesquisa. Gall, Borg e Gall (1996) acreditam que a revisão bibliográfica deve delimitar o problema de pesquisa, demonstrar o ganho que a percepção da metodologia fornece e buscar todas as possíveis linhas de investigação daquele assunto de interesse.

Como pontos de atenção para o desenvolvimento de uma pesquisa Miguel (2010) afirma que é necessário cuidado para que se tenha o mesmo conceito sendo abordado e trabalhado ao longo de todo o conteúdo, recomendando atenção em relação aos métodos que serão empregados, pois estes guiarão a pesquisa.

Randolph (2009) considera que uma revisão de literatura falha faz com que seja elaborada uma dissertação defeituosa. Boote e Beile (2005) defendem que um pesquisador não pode elaborar uma pesquisa significativa sem antes entender a literatura envolvida no assunto de interesse. Os autores afirmam que muitas vezes os pesquisadores iniciam a revisão bibliográfica já pensando em seu fim, mas quando esta é mal desenvolvida ou mesmo detém uma conceituação pobre é possível se pensar que irá existir problemas com as outras partes da pesquisa.

$\mathrm{Na}$ revisão bibliográfica deste estudo buscou-se compreender as abordagens conceituais que sustentaram a estruturação de startups de sucesso, analisando em profundidade o processo de desenvolvimento de inovações. Conforme mencionado anteriormente esta revisão teve início com o tema Inovação, que desencadeou a necessidade de melhor entendimento da Cadeia de Valor da Inovação enquanto uma proposta de fases para inovar. Considerando a busca por referenciais que estimulem o desenvolvimento de inovações tornou-se interessante buscar por conhecimentos na área de $\underline{\text { Design, }}$ reconhecida pela sua capacidade de gerar inovações. No contexto do Design, chegou-se ao Design Thinking, abordagem que busca aplicar métodos e ferramentas da área Design em outras áreas de conhecimentos. Para melhor aprofundamento do cenário da pesquisa foi preciso incorporar o tema Empreendedorismo, cujo foco principal foi a teoria da Lean Startup, abordagem ágil com foco na rápida estruturação de novos negócios. Finalmente com as ideias principais sobre o negócio em mente, tornou-se relevante 
representar o seu Modelo de Negócios e, por apresentar-se enquanto ferramenta gráfica efetiva para estruturar Modelos de Negócios buscou-se aprofundamento na abordagem do Business Model Canvas, uma versão que resume e foca na geração de valor e atendimento das necessidades dos clientes.

Ao longo do processo de revisão bibliográfica desta pesquisa buscou-se identificar todo o material que trata dos assuntos de interesse (Cadeia de Valor da Inovação, Design Thinking, Lean Startup e Business Model Canvas), mas como estes em sua maioria são assuntos recentes, foi difícil obter consenso quanto às suas definições; desta maneira, esta pesquisa buscou trabalhar esta questão tendo em vista o seu esclarecimento e assim possibilitando contribuir com a comunidade acadêmica e alcançar a elaboração do Framework Cíclico.

\subsection{Painel de Especialistas}

Este tópico apresenta os conceitos que nortearam a realização do painel de especialistas desta pesquisa, incluindo sua conceituação, elaboração do questionário, testes-piloto, revisões, e seleção e envio aos respondentes. Segundo Flick (2004), painel de especialistas é uma metodologia de pesquisa que permite maior aproximação em relação ao cotidiano do entrevistado e que surgiu enquanto uma variação das entrevistas estruturadas, já que estas são consideradas artificiais pois o entrevistado tende a ser apartado do seu cotidiano. Assim, de forma a buscar maior aderência com os princípios deste método, nesta pesquisa foi realizada a aplicação de questionário a distância com a preocupação do respondente estar inserido em seu cotidiano e sempre proporcionando questões abertas para que o respondente pudesse expressar a sua real opinião e incluir todas as considerações relevantes e necessárias.

Ainda segundo Flick (2004), entrevistas realizadas em grupos são vantajosas pelo baixo custo de sua aplicação e dispêndio de tempo, além da riqueza de dados que fornecem, ultrapassando os limites da capacidade de resposta relacionada a um determinado assunto de um único entrevistado. Para Pérez e Martínez (2008), o painel de especialistas é composto por pessoas reconhecidas por sua trajetória relacionada a um determinado tema, sendo célebres por sua experiência e que podem fornecer informações, juízos, evidências e comentários relevantes. 
Patton (1990) define o painel de especialistas como entrevistas individuais realizadas num grupo composto geralmente por seis a oito pessoas, que são entrevistadas individualmente a respeito de um tópico especifico, tendo a duração média entre trinta minutos e duas horas. Ainda segundo o autor, é uma técnica qualitativa de coleta de dados que possibilita a realização de controles de qualidade, pois uma opinião pode compensar outra, de forma que opiniões radicais e falsas podem ser eliminadas uma vez que é possível avaliar quando existe uma opinião compartilhada, é um método de coleta de dados muito eficiente.

Patton (1990) considera que o painel de especialistas deve ser visto como uma entrevista e não uma discussão. Segundo Lucena e Casaca (2013), o painel de especialistas pode ser utilizado para obtenção de conhecimento sem que ocorra confronto frente a frente garantindo o anonimato das respostas.

Para André, Ciampone e Santelle (2013), esta metodologia de pesquisa consiste num questionário interativo, que circula por algumas vezes entre especialistas de uma determinada área, cabendo a estes responder de acordo com suas convicções; seu uso é fruto de uma busca pela identificação de tendências e de perspectivas de opiniões em relação a um determinado assunto de interesse.

Segundo Pérez e Martínez (2008), a seleção dos especialistas que irão constituir o painel é uma parte crítica do processo. Numa tentativa de facilitar o processo de seleção dos membros do painel de especialistas Skjong e Wentworht (2000) propõem alguns critérios para a sua seleção:

- Experiência com julgamentos e tomada de decisão baseada em evidências, tais como publicações, prêmios e investigações.

- Reputação na comunidade relacionada ao assunto de interesse.

- Motivação e disponibilidade para participar.

- Características como imparcialidade e confiança em si mesmo.

Para Flick (2004) o pesquisador é livre para decidir a forma "certa" de realizar um painel de especialistas de acordo com os objetivos da sua pesquisa. O painel de especialistas desta pesquisa basicamente consistiu nas seguintes etapas:

1 - Elaboração do questionário.

2 - Envio do questionário para testes-piloto, obtenção de retorno e ajustes no questionário proposto. 
3 - Seleção dos potenciais participantes do painel de especialistas e envio dos questionários aos especialistas selecionados.

4 - Análise das respostas obtidas nos questionários retornados pelos especialistas selecionados.

5 - Elaboração da terceira versão do Framework Cíclico.

A seguir serão detalhados os passos propostos para o desenvolvimento e aplicação do painel de especialistas.

\subsubsection{Elaboração do questionário}

De acordo com Tull e Hawkins (1990), o desenho de um questionário é uma abordagem de formalização, de questionar alguém em relação a algo, podendo ser utilizado para mensurar comportamentos, características demográficas, níveis de conhecimento, atitudes e opiniões. Ainda de acordo com 0 autor as maiores decisões relacionadas com o seu desenho são:

- Preliminares - antes de construí-lo é importante saber exatamente qual informação será coletada com cada técnica.

- Conteúdo - focam na natureza geral e em como as informação devem ser desenhadas para a produção do conhecimento necessário.

- Fraseologia das questões - é a tradução da questão desejada em palavras e frases que possam ser fácil e claramente entendidas.

- Formatos de resposta - o questionário pode incorporar questões abertas e questões fechadas, com alternativas limitadas de respostas.

- Sequência das questões - ordem com que os respondentes recebem as questões.

- Layout - o layout do questionário deve facilitar seu uso.

- Teste-piloto - auxiliam na validação de que o questionário é claro, suas perguntas são compreensíveis e permitem a resposta das indagações da pesquisa.

Para Tull e Hawkins (1990), a primeira seção de um questionário introduz a pesquisa ao respondente, podendo reduzir erros e vieses de compreensão e, por este motivo, deve ser bem construída. As seções internas contém os itens e escalas para mensuração dos tópicos questionados, existindo inúmeras técnicas e estilos 
que consideram formatos de questões, escalas, elementos e seções, que podem ser organizados de diversas formas. Entre as seções internas vale destacar a seção que apresenta questões para classificar os respondentes de acordo com suas principais características, permitindo que sejam agrupados e comparados.

Tull e Hawkins (1990) destacam que uma pesquisa costuma ter diversas perguntas e é comum agrupá-las para simplificar e facilitar suas respostas, tornando o questionário mais eficiente. Ainda segundo os autores normalmente o respondente deve responder todas as questões, mas eventualmente apenas algumas são efetivamente aplicáveis para cada categoria de respondente e, neste casos, devem existir perguntas que filtrem o que deve ser respondido.

Alreck e Settle (1995) definem as questões enquanto os elementos que performam a interrogação, o componente mais essencial da validade e da confiabilidade em relação aos resultados de uma pesquisa, sendo o elemento isolado de maior efeito nos resultados e, por este motivo, devem ser compostas com cuidado e propriedade. Os autores ainda elencam 3 atributos que as questões devem possuir:

- Foco - deve ser focada no assunto ou tópico específico que necessita de confirmação.

- Brevidade - deve ser o menor e mais breve possível, ponto também destacado por Payne (1951).

- Simplicidade - a questão deve ser expressada com a maior simplicidade e clareza que lhe é permitido, pois assim todos os respondentes a interpretarão da mesma maneira, conceito também defendido por Payne (1951).

Para Alreck e Settle (1995) as questões possuem outros elementos importantes, tais como vocabulário e gramática. Segundo Payne (1951), a importância das palavras é tão grande quanto as amostras selecionadas. Alreck e Settle (1995) destacam duas fontes de vieses nas respostas: o viés instrumental, que ocorre quando instruções, questões, escalas ou opções de respostas induzem as respostas do respondente, e o viés do respondente, que consiste numa predisposição deste em relação às questões apresentadas.

De acordo com Alreck e Settle (1995) o formato das questões pode ser estruturado ou desestruturado, onde o primeiro lista possíveis respostas para o 
respondente e o segundo apenas questiona, deixando a resposta em aberto, não apresentando alternativas. No caso das questões estruturadas existe a composição de categorias (PAYNE, 1951). Alreck e Settle (1995) destacam diversos tipos de escalas convencionais, listas de opções ofertadas ao pesquisado, tais como a escala Likert, de frequência verbal e ordinal, entre outras. São apresentadas também as combinações de escalas, que reduzem a tarefa das respostas e facilitam gravações, podendo ser listas ou matrizes de múltiplas classificações ou mesmo escala de diagrama. Os autores também apresentam as escalas não verbais, compostas por imagens ou mesmo gráficos.

Forza (2002) considera que para conseguir as informações dentro de um conceito específico é necessário escolher a escala de opções de respostas para as perguntas e identificar os respondentes que são mais apropriados para cada tipo de pergunta, além de colocar junto ao questionário questões que facilitem e motivem o respondente a continuar respondendo. Para o autor, no questionário é necessário ter uma linguagem adequada, de acordo com o nível do respondente, tendo cuidado para que não se apresente questionamentos ambíguos.

O questionário para os especialistas deste estudo foi lapidado por cerca de oito meses e em sua versão final contou com 38 questões, além de apresentar espaços para que os especialistas pudessem expressar suas considerações qualitativas em todas as questões. Desta maneira as questões estruturadas apresentavam opções de resposta utilizando escala Likert de 5 pontos (Muito Relevante, Relevante, Indiferente, Pouco Relevante e Irrelevante), e em suas questões abertas foram apresentados espaços para que o respondente pudessem compartilhar sua experiência. As questões iniciais do questionário apresentavam perguntas para classificação e segmentação dos respondentes. Como introdução do questionário foi elaborada uma carta de apresentação justificando a pesquisa e o desenho do Framework Cíclico. O questionário completo é apresentado no Anexo 2 deste documento, incluindo a carta de apresentação da pesquisa.

\subsubsection{Testes-piloto e ajustes do questionário}

Após o questionário finalizado foram realizados os testes-piloto. Segundo Payne (1951), no teste piloto o respondente deve justificar o porque das respostas dadas. Por sua vez, Forza (2002) considera que a elaboração dos questionários 
deve ser seguida pela realização de um teste piloto, onde processos e instrumentos de pesquisa devem ser validados e então classificados como adequados ou não. Ainda segundo Forza (2002), é válido efetuar o teste piloto do questionário com colegas, pessoas experientes na indústria, e até mesmo com pessoas que são o alvo para o questionário.

Para Miguel (2010) é muito importante a realização do teste piloto antes do início efetivo da coleta de dados, sendo preciso que o teste permita validar os procedimentos de aplicação do questionário para que assim seja possível chegar aos ajustes e correções necessárias.

Nesta pesquisa o teste piloto foi realizado com dois respondentes: o primeiro um especialista em startups que validou o alinhamento dos questionamentos com as descobertas desejadas e a clareza das questões; o segundo respondente é especialista em metodologia de pesquisa e verificou se existia concordância no que o estudo buscava esclarecer e as questões que compunham o questionário. Os resultados dos testes-piloto deste estudo são apresentados no item 4.3.1.

\subsubsection{Seleção dos respondentes do Painel de Especialistas e envio do questionário}

Neste estudo o grupo identificado de especialistas foi composto por quinze especialistas ligados à startups. Sua seleção se deu por meio da identificação de contatos existentes e pela busca por contatos considerados relevantes, incluindo especialistas que se mostrassem dispostos a contribuir com esta pesquisa.

Quanto à sua duração buscou-se estruturar um questionário possível de ser respondido em vinte minutos, de forma que a tarefa não fosse muito trabalhosa aos especialistas, que participaram da pesquisa voluntariamente, sem nenhum tipo de remuneração financeira, contribuindo apenas pelo desejo de compartilhar e adquirir mais conhecimentos relacionados com o universo das startups.

Os questionários foram enviados aos especialistas em 22 de junho de 2016 e semanalmente foi enviado um lembrete aos respondentes que ainda não haviam respondido ao questionário. O período de aplicação foi encerrado em 29 de julho de 2016. Sua aplicação foi virtual, buscando viabilizar a participação do maior número possível de respondentes e garantindo que nenhum respondente assumisse posição dominante. O questionário foi estruturado utilizando a ferramenta formulário do 
Google Drive, gratuita, de fácil utilização e já utilizada em pesquisas anteriores. Os resultados do painel de especialistas são apresentados no item 4.3 deste estudo.

\subsection{Survey}

A última etapa desta pesquisa consistiu na aplicação de survey, incluindo as etapas de elaboração do questionário, testes-piloto, revisão do questionário, seleção e envio do questionário aos respondentes e análise dos resultados obtidos. Miguel (2010) considera que as surveys são ferramentas utilizadas em investigações que buscam principalmente contribuir com o conhecimento dentro de uma determinada área de conhecimentos e para isto utilizam a coleta de dados e informações sobre indivíduos ou sobre ambientes nos quais os indivíduos estão inseridos.

Para Rasinski (2005), surveys são ferramentas poderosas para as pesquisas, utilizadas pelos cientistas sociais para estudar fenômenos sociais, abordando o estudo de organizações e de pessoas na sociedade, consistindo num rico conjunto de técnicas utilizadas para obter informações a respeito de atitudes individuais, valores, comportamentos, opiniões, conhecimentos e circunstâncias.

Segundo Sorensen, Mattson e Sundbo (2010), as surveys e outros métodos quantitativos mostram adequação em termos de mensuração e entendimento do processo de inovação. Klassen e Jacobs (2001) mencionam que a difusão dos computadores pessoais, da internet e do e-mail, fez com que muitos pesquisadores passassem a desenvolver mais surveys. Ainda segundo os autores, a tecnologia tem auxiliado muito na ampliação destas, permitindo a distribuição dos questionários de forma on-line e o uso de softwares para a construção e análise dos resultados obtidos. Na área de Gestão de Operações verifica-se ampla aceitação das surveys, em especial pela sua capacidade de investigação de conceitos, de análise e de teste de teorias, além de seus propósitos descritivos (KLASSEN; JACOBS, 2001).

Miguel (2010) considera que um dos métodos mais apropriados para a condução de uma pesquisa quantitativa na área de Engenharia de Produção é a survey. Forza (2002) acrescenta que é com base nas hipóteses e propósitos da pesquisa que se definem as principais necessidades de informações da survey, que deve contar com um processo de pesquisa cuidadosamente desenhado, pois assim se poderá assegurar a qualidade do processo de pesquisa e prevenir futuros problemas potenciais. 
Neste estudo foi aplicada survey junto a empreendedores de startups de sucesso, num processo que consistiu de:

1 - Elaboração do questionário.

2 - Envio do questionário para realização do teste piloto, retorno e ajustes no questionário proposto.

3 - Seleção dos participantes da survey: a partir da identificação das aceleradoras atuando no país foram identificadas as startups em processo de aceleração nestas aceleradoras ou mesmo as startups já aceleradas, e então foi realizado contato com os empreendedores destas startups selecionadas. O questionário da pesquisa foi encaminhado eletronicamente aos empreendedores selecionados.

4 - Obtenção e análise de retorno dos questionários enviados aos empreendedores das startups de sucesso. Este passo possibilitou a obtenção da quarta e final versão do Framework Cíclico (apresentada no item 5 desta pesquisa).

A seguir serão detalhados os passos realizados no desenvolvimento e na aplicação da survey juntamente aos empreendedores das startups de sucesso (em processo de aceleração ou já aceleradas por aceleradoras brasileiras).

\subsubsection{Elaboração do questionário}

Para Miguel (2010), numa survey o desenvolvimento do questionário não é uma tarefa fácil, já que é preciso definir as quantidades e tipos de questões, o uso ou não de escalas numéricas, a forma de apresentação das questões, além de garantir uma relação estreita entre as perguntas e a teoria analisada. Forza (2002) destaca que as surveys são dependentes dos instrumentos estruturados utilizados para a coleta de informações, devendo-se ter muito cuidado no seu processo de desenvolvimento.

Para Miguel (2010), uma pré-análise dos dados é importante, podendo ser feita assim que os dados estiverem disponíveis, servindo para verificar a qualidade destes, a distribuição de frequência das variáveis e até mesmo o cálculo das medidas de dispersão e de tendência central. Como a questão teórica relacionada com a estruturação de questionários foi amplamente abordada no item 3.2.1 deste estudo o assunto não será prolongado. 
O questionário final para teste piloto contou com 25 questões fechadas, além de apresentar questões abertas para que os respondentes pudessem incluir suas considerações qualitativas. O questionário inicialmente apresentava a pesquisa e a proposta do Framework Cíclico, seguido por questões relacionadas com os aspectos demográficos dos respondentes e a seguir pelas questões que buscavam a efetiva validação do Framework Cíclico. A escala utilizada foi a escala Likert de cinco pontos com foco na verificação da frequência de aplicação das etapas na estruturação das startups ("em todos os projetos", "na maioria dos projetos", "em cerca de metade dos projetos", "em poucos projetos" e "em nenhum projeto").

Como ferramenta para apresentação do questionários e coleta de informações foi novamente utilizado o Google Drive, selecionado por ser uma plataforma familiar aos pesquisadores e respondentes, gratuita e que consegue atender aos requisitos desta pesquisa. Uma vez com os questionários finalizados o estudo passou para a etapa de testes-piloto.

\subsubsection{Testes-piloto e ajustes do questionário}

No item 3.2.2 deste estudo já foi apresentada a definição de teste piloto e dos seus conceitos e, por este motivo, o assunto não será apresentado novamente. Os testes-piloto foram realizados junto a 2 empreendedores, buscando verificar a adequação da sua linguagem e dos objetivos da pesquisa. Assim o questionário final foi composto por 55 questões e com o questionário final estruturado teve início a seleção dos respondentes e o envio dos questionários eletronicamente. A versão final do questionário encontra-se no Anexo 3 deste estudo e os resultados do testespiloto estão no item 4.4.1.

\subsubsection{Seleção dos respondentes da Survey e envio do questionário}

Para Rasinski (2005), na survey um dos primeiros passos é a definição da população, seguido pela seleção da amostra, desenvolvimento e administração do questionário, e coleta e análise de dados. As surveys utilizam métodos de amostragem cientifica e coleta de informações a respeito de subconjuntos do total de elementos, sendo que quando desenvolvida corretamente as características da população total serão extraídas dos resultados obtidos com as amostras participantes (RASINSKI, 2005). 
Para Forza (2002), o processo de amostragem da pesquisa determina informações a respeito da população com níveis de acuracidade de conhecimento. Ainda em termos de amostragem o autor define os seguintes conceitos:

- População - é o grupo inteiro de pessoas ou mesmo organizações que o estudo busca investigar.

- Amostra - é uma parte da população, são os membros selecionados.

- Assunto - é um membro único da amostra.

- Amostragem - é o processo de selecionar um número suficiente de membros da população para entender as características e propriedades do assunto.

Forza (2002) menciona que a aleatoriedade da amostragem está associada à habilidade desta em representar a população de interesse, de forma consistente com os processos estatísticos usados para a mensuração da qualidade e avaliação e teste das hipóteses. Ainda de acordo com o autor a seleção da amostra pode ou não ser probabilística.

Inicialmente os potenciais respondentes da survey deste estudo incluíam a população de empreendedores de startups de sucesso. Considera-se startups de sucesso como aquelas que já existem há mais de um ano, já que, segundo Arruda et al. (2013), 25\% destas são descontinuadas com menos de 1 ano de existência. Muitas startups iniciam como negócios informais ou como negócios que, apesar de formais, não constam em registros acessíveis aos pesquisadores. Por este motivo e considerando que o foco principal da pesquisa são startups consideradas como bem sucedidas a amostragem de empreendedores respondentes foi selecionada entre as startups que estivessem em processo de aceleração ou que tivessem sido aceleradas por aceleradoras brasileiras no período de aplicação da pesquisa.

Para Abreu e Campos (2016), as aceleradoras são verdadeiros centros de empreendedorismo e tem obtido destaque na criação e na formação de uma nova geração de empreendedores no Brasil. As aceleradoras tem por objetivo apoiar e investir no desenvolvimento e crescimento rápido das startups. Ainda segundo Pauwels et al. (2015), a primeira aceleradora foi a "Y Combinator", fundada em 2005 em Cambridge, Massashusetts. No Brasil, segundo Abreu e Campos (2016), existem 40 aceleradoras de startups em operação e em média cada uma destas acelera 14 startups por ano. Até janeiro de 2016 foram aceleradas cerca de 1.100 startups no 
Brasil, considerando um investimento entre $R \$ 45$ mil e $R \$ 255$ mil por startup, totalizando um investimento aproximado de $\mathrm{R} \$ 51$ milhões (ABREU; CAMPOS, 2016).

$\mathrm{Na}$ pesquisa foram acessadas as startups de 34 aceleradoras, selecionadas pelo fato de serem as únicas que apresentavam dados e informações de contato na internet, disponíveis dentro dos sites das aceleradoras. Assim, a amostragem desta etapa do estudo apresenta representatividade de $85 \%$ em relação às aceleradoras brasileiras e $77,8 \%$ das startups em processo de aceleração ou aceleradas por aceleradoras brasileiras. O processo de envio do questionário da survey foi iniciado em 24 de agosto de 2016 e finalizado em 05 de dezembro de 2016 e, durante este período, a autora buscou ativamente estimular e aumentar a participação dos empreendedores para assim alcançar a maior representatividade possível. Para tal inicialmente foi realizado contato via e-mail; porém, pela baixa taxa de retorno obtida, passou-se ao contato telefônico tendo em vista a aproximação do empreendedor, explicando a pesquisa e seus objetivos e convidando para responder ao questionário.

Já a distribuição dos questionários se deu por meio virtual, pois desta forma acredita-se que é possível ampliar o alcance da pesquisa, tendo-se um maior número de respondentes e consequentemente taxa de retorno. O questionário enviado aos empreendedores de startups foi estruturado por cerca de dez meses, tendo sido desenvolvido em paralelo com a aplicação dos questionários enviados aos especialistas, aguardando-se a análise final dos questionários respondidos pelos especialistas para então realizar a finalização do questionário da survey. 


\section{$4 \quad$ RESULTADOS}

Neste capítulo serão apresentados os resultados obtidos com a aplicação dos diferentes métodos empregados neste estudo, incluindo a revisão bibliográfica, a revisão de diferentes pontos da dissertação estruturadas a partir das recomendações obtidas com a banca de qualificação, os resultados obtidos com a aplicação do painel de especialistas e, finalmente, os resultados com a aplicação de survey. Com todos estes resultados espera-se contribuir com a academia com a proposta de uma versão final de Framework Cíclico que permite a geração e refinamento de conceitos, assim como a estruturação inicial da operação de novas startups de sucesso, tópico que será detalhado no item 5 desta pesquisa.

\subsection{Revisão Bibliográfica e elaboração da primeira versão do Framework}

\section{Cíclico}

Esta seção detalha o processo de revisão bibliográfica e elaboração da primeira versão do Framework Cíclico. O processo teve início com a busca por um melhor entendimento das abordagens de interesse (Cadeia de Valor da Inovação, Design Thinking, Lean Startup e Business Model Canvas), seguindo com a apresentação dos resultados obtidos com o desenvolvimento da revisão bibliográfica e o detalhamento das fases e etapas propostas na primeira versão do Framework.

\subsubsection{Resultados da Revisão Bibliográfica}

Como primeiro passo para o desenvolvimento do Framework Cíclico foi realizada ampla revisão bibliográfica, que permitiu a consolidação dos conceitos das abordagens propostas para sua composição. Esta revisão se justifica pela amplitude dos conceitos existentes, ainda recentes e pouco explorados em publicações e academicamente, incluindo:

- Cadeia de Valor da Inovação - estabelece formas de endereçar a criação de inovações, propondo um framework que faz com que os executivos se questionem a respeito dos esforços para a inovação (HANSEN; BIRKINSHAW, 2007).

- Design Thinking - abordagem que busca incentivar a criatividade, assim como estabelecer novos caminhos para a inovação, utilizando a 
sensibilidade e ferramentas dos designers para conhecer profundamente as necessidades que motivam as pessoas, de forma a gerarem ideias; a abordagem incorpora visão multidisciplinar, evidenciando a capacidade de tangibilizar processos e pensamentos que focam no ser humano, transformando ideias em resultados viáveis e alinhados aos objetivos organizacionais (JOHANSSON-SKÖLDBERG; WOODILLA; CETINKAYA, 2013; BUCHANAN, 1992; MUELLER; THORING, 2012; VIANNA et al., 2011; IDEO, 2012; BROWN, 2008).

- Lean Startup - modelo que auxilia no desenvolvimento de novos negócios, direcionado pela avaliação do consumidor desde o início do processo; aplica o pensamento Lean no contexto do processo de inovação e foi construído com base em modelos de gestão e processos de desenvolvimento; pode ser compreendido como um novo processo, que busca tornar menos arriscado a criação de uma nova empresa, defendendo a experimentação acima de planos elaborados e a opinião dos consumidores acima da intuição (SILVA et al., 2013; POPPENDIECK; CUSUMANO, 2012; COBB; POIRIER, 2013; RIES, 2011; KARLSSON; NORDSTRÖM, 2012; BLANK, 2003; MELO et al., 2013).

- Business Model Canvas - modelo utilizado para verificar o potencial de um novo negócio considerando diferentes perspectivas; identifica o valor que será entregue ao consumidor, viabiliza o estabelecimento de hipóteses relacionadas com este valor e facilita para que a organização identifique suas fontes de vantagem competitiva, auxiliando no processo organizacional decisório (CHEN; CHENG; MEHTA, 2013; BOCKEN et al., 2013; NIELSEN; MONTEMARI, 2012; ABRAHAM, 2013; SLEUWAEGEN, 2013; BANCHIERI; BLASCO; CAMPA-PLANAS, 2013; MARTIKAINEN; NIEMI; PEKKANEN, 2013; GHEZZI, 2012; GELBMANN; HAMMERL, 2014).

A revisão bibliográfica apresentada no capítulo 2 incorpora estes conceitos e evidencia um cenário onde o diferencial organizacional reside em quão bem se é capaz de atender e surpreender seus consumidores. 


\subsubsection{Primeira versão do Framework Cíclico}

Buscando atender ao principal objetivo deste estudo, elaborar um Framework Cíclico capaz de representar o efetivo conjunto de fases e etapas relevantes, empregadas e recomendadas para estruturar startups de sucesso, esta seção apresenta a primeira versão do Framework, no qual a Cadeia de Valor da Inovação atua como elo integrador entre as demais abordagens, o Design Thinking auxilia na geração de insights inovadores, o Lean Startup incorpora conceitos como prototipação, feedback do consumidor, flexibilidade e agilidade, e o Business Model Canvas permite a estruturação do plano de objetivos desta nova organização e viabiliza o teste das hipóteses estabelecidas pelo Lean Startup. Esta primeira versão do Framework foi estruturada a partir dos conceitos teóricos obtidos com a revisão de literatura.

A primeira versão o Framework Cíclico, apresentada pela Figura 15, foi estruturada considerando os pontos comuns e complementares das abordagens mencionadas. Este referencial foi apresentado e validado com a realização de dois estudos de casos junto à startups de sucesso, utilizadas como "testes-piloto" (o roteiro utilizado nas entrevistas aplicadas nestes estudos de caso encontra-se no Anexo 1 deste documento). Vale destacar que os resultados obtidos com os estudos destas startups não resultou em mudanças na estrutura do Framework Cíclico. 
Figura 15: Primeira versão do Framework Cíclico, baseado na revisão de literatura e dois estudos de caso, antes da qualificação

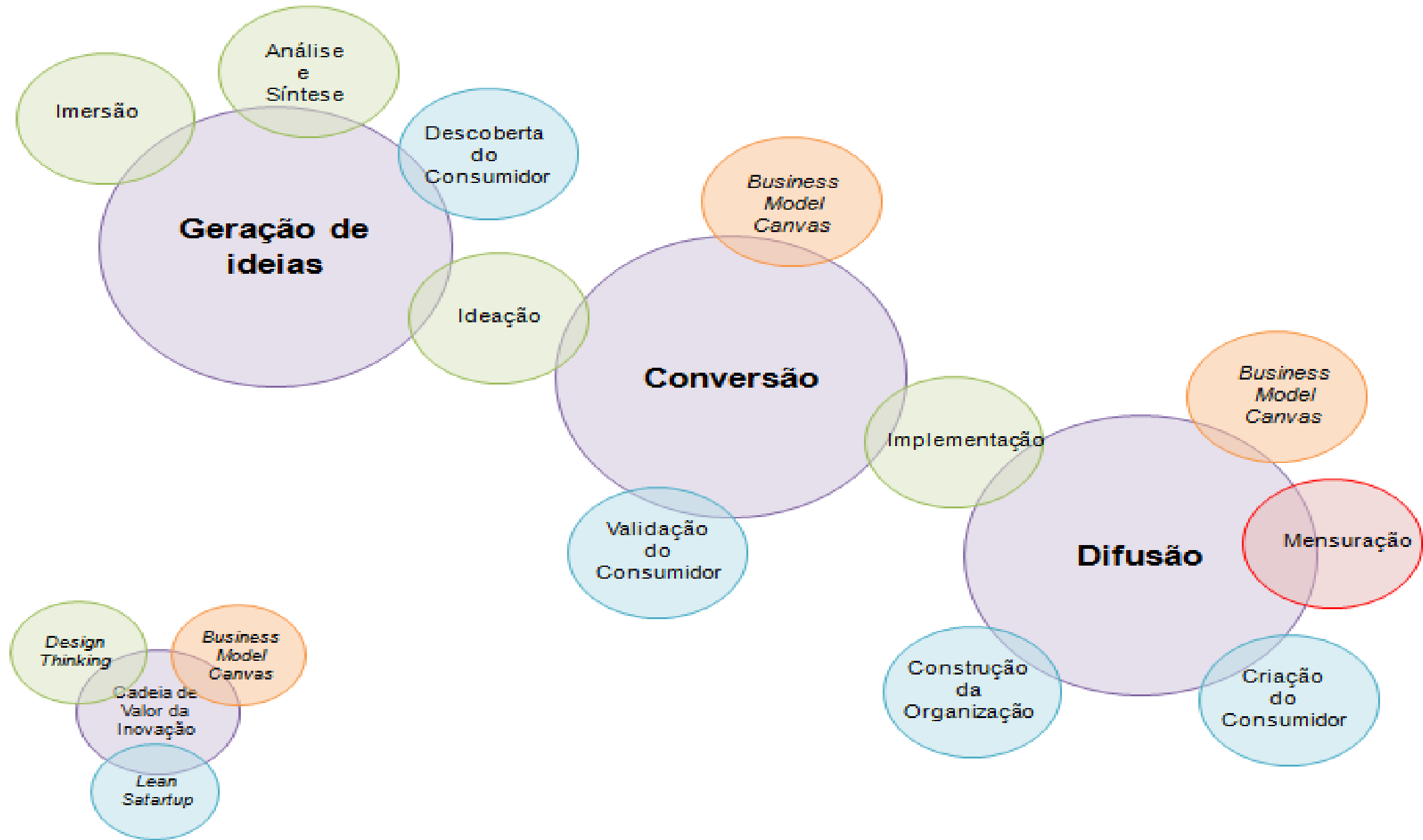

Fonte: Elaborado pela autora. 
Detalhando a Figura 15:

- Geração de ideias - inclui as fase de Imersão e Análise e Síntese do Design Thinking, onde inicialmente busca-se o entendimento da situação e do usuário para então dar origem à solução, compreensão necessária para a geração de ideias e para o estabelecimento de padrões e conexões. Outra ferramenta incorporada é o Lean Startup com a Descoberta do Consumidor, buscando a geração de soluções úteis. O referencial incorpora as diretrizes propostas na fase Ideação do Design Thinking, incluindo ferramentas como personas, mapa de empatia, jornada do usuário, brainstorming, workshop de co-criação e cardápio de ideias. Como resultado esperado nesta fase vale destacar o entendimento da situação, o conhecimento dos consumidores e a geração de ideias com foco nestes.

- Conversão - fase em que a seleção e a prototipação das melhores ideias podem ser facilitadas com a aplicação da matriz de posicionamento proposta na etapa de Ideação do Design Thinking. Outra ferramenta empregada nesta fase é o Business Model Canvas, que permite o desenho da proposta de valor e a compreensão de como será estabelecida vantagem competitiva. Também é realizada a Implementação do Design Thinking, colocando em prática o Produto Mínimo Viável tendo em vista seus testes e Validação do Consumidor, proposto pelo Lean Startup. Como resultado tem-se a matriz de posicionamento, que auxilia no desenho do plano de negócios, a qual será testada para validação da proposta junto aos consumidores.

- Difusão - busca propagar a inovação por meio da Implementação, do Design Thinking, quando as ideias selecionadas são transformadas em algo tangível tendo em vista melhor avaliação. Neste momento também se aplica o Business Model Canvas para revisão da proposta. A abordagem do Lean Startup propõe então a Criação do Consumidor e a Construção da Organização onde em vista o aumento expressivo do número de novos consumidores e com o modelo validado inicia-se a busca pela criação de efetiva de 
mercado para a organização ou mesmo uma nova unidade de negócios dentro de uma organização existente.

O escalonamento da nova startup é viabilizado com a implementação de ferramentas de mensuração, em especial considerando duas métricas essenciais, a Análise Cohort, em que consumidores são agrupados de acordo com suas características principais, e o SplitTest, que auxilia na compreensão de quais são as características mais efetivas de produtos e serviços considerando as preferências dos clientes.

Com a revisão bibliográfica finalizada e com o primeiro desenho do Framework Cíclico estruturado e validado por estudos de caso preliminares, 0 trabalho foi submetido em exame de qualificação e, uma vez aprovado, foi continuado tendo em vista a incorporação das sugestões da banca: rever a justificativa do estudo e o layout empregado no Framework, além de buscar a análise e validação do Framework Cíclico junto a um painel de especialistas.

\subsection{Revisões recomendadas na Qualificação e segunda versão do}

\section{Framework Cíclico}

Este item apresenta como foi realizado o processo de revisão da justificativa do estudo, do nome e do layout da primeira versão do Framework Cíclico, tendo em vista sua posterior apresentação ao painel de especialistas.

\subsubsection{Revisão da justificativa}

Conforme recomendação da banca a justificativa deveria compreender o desenvolvimento de produtos e de serviços no contexto das startups ou então focar-se exclusivamente no desenvolvimento das startups considerando principalmente a identificação das necessidades e a validação das propostas de valor junto aos principais clientes da organização. Para atingir os objetivos desta pesquisa foi considerado como relevante e importante priorizar o desenvolvimento de startups a partir da interação com seus segmentos de clientes, sem a necessidade de focar na revisão no desenvolvimento de produtos e serviços, tendo sido retirado este assunto do estudo. 


\subsubsection{Revisão do nome e layout da primeira versão do Framework Cíclico e segunda versão do Framework Cíclico}

O Framework Cíclico recebia o nome de Modelo Integrado antes da Qualificação mas, seguindo recomendação da banca, foi realizada a alteração e adotado o termo "Framework", que funciona como uma estrutura para a agregação de métodos, processos e técnicas, possuindo pressupostos que necessariamente orientem a sua execução (GESTÃO DE PROJETOS NA PRÁTICA, 2017), já que o termo "Modelo" representa resumidos processos, relacionamentos e variáveis, sem proporcionar as orientações específicas para a sua implementação (GESTÃO DE PROJETOS NA PRÁTICA, 2017). A inclusão do termo "Cíclico", mostrou-se relevante para garantir ênfase no aspecto do Framework poder ser continuamente aplicado e viabilizado o retorno às fases e etapas anteriores, quando necessário no decorrer de seu processo de aplicação.

A mudança no layout do Framework iniciou com a incorporação da sugestão da banca para que este seguisse a forma de um funil, dando a ideia de que é proposto um processo que gera o afunilamento das ideias, ou seja, se inicia com várias ideias e no decorrer do processo estas são reduzidas até que seja(m) alcançada(a) a(s) ideia(s) que norteará(ão) a estruturação de uma startup de sucesso. A primeira versão do novo desenho, utilizada neste projeto de pesquisa por alguns meses, é apresentada na Figura 16. Porém, como esta figura ainda não agradava por completo, foram realizadas mais algumas tentativas e obtida a proposta final de layout para esta segunda versão do Framework Cíclico, apresentada na Figura 17.

Em relação às mudanças nas fases e etapas do novo Framework Cíclico não ocorreram mudanças de fases e foi retirada a etapa de "Mensuração" devido à sua complexidade e necessidade de detalhamento. Ocorreram também mudanças no posicionamento das etapas, ficando a etapa de "Ideação" apenas na fase de "Conversão" e a etapa de "Implementação" apenas na fase de "Difusão". 
Figura 16: Segunda versão parcial do Framework Cíclico, baseado na revisão de literatura e dois estudos de caso, após qualificação

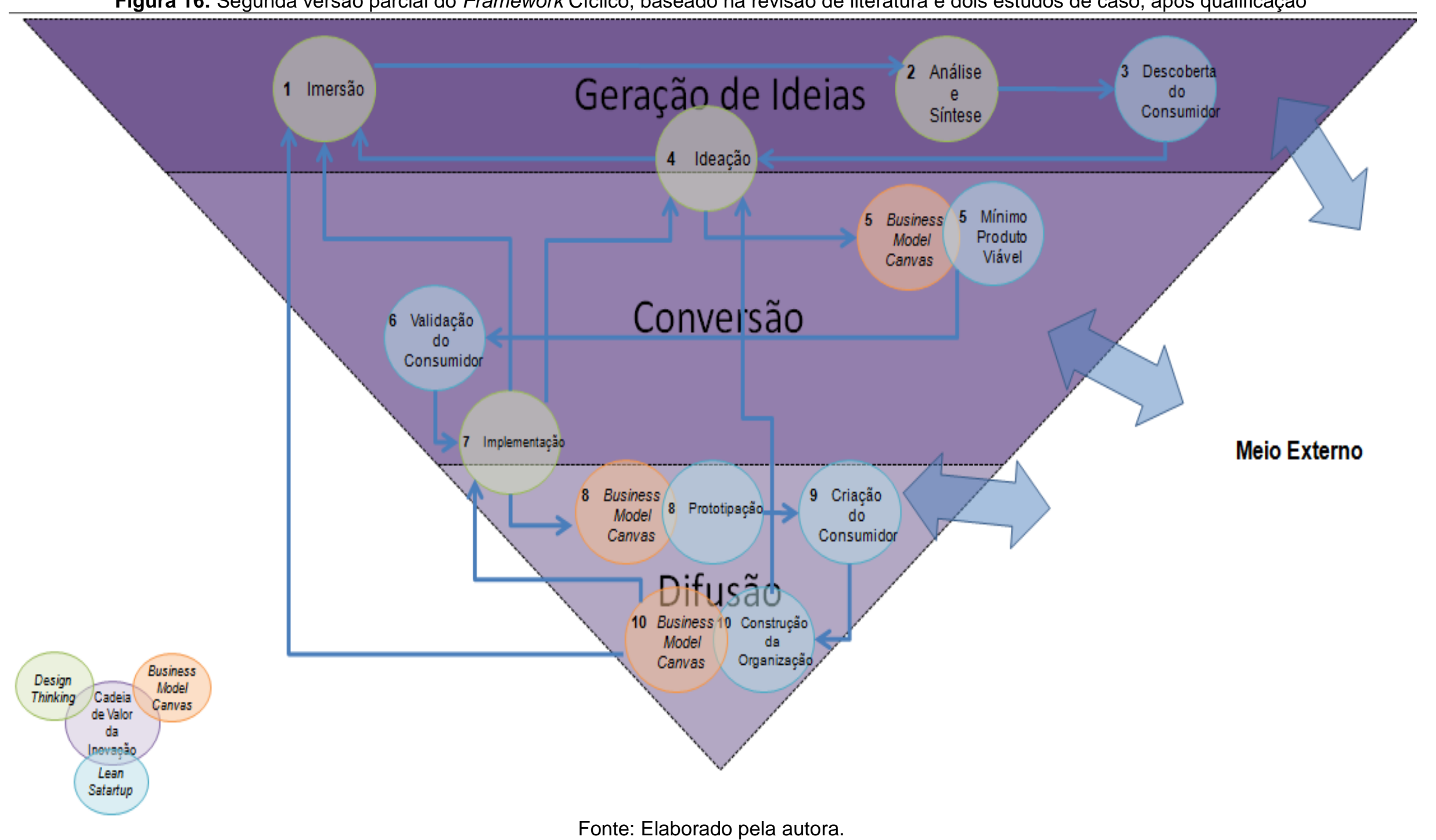

Fonte: Elaborado pela autora. 
Figura 17: Segunda versão final do Framework Cíclico, baseado na revisão de literatura e dois estudos de caso, após qualificação

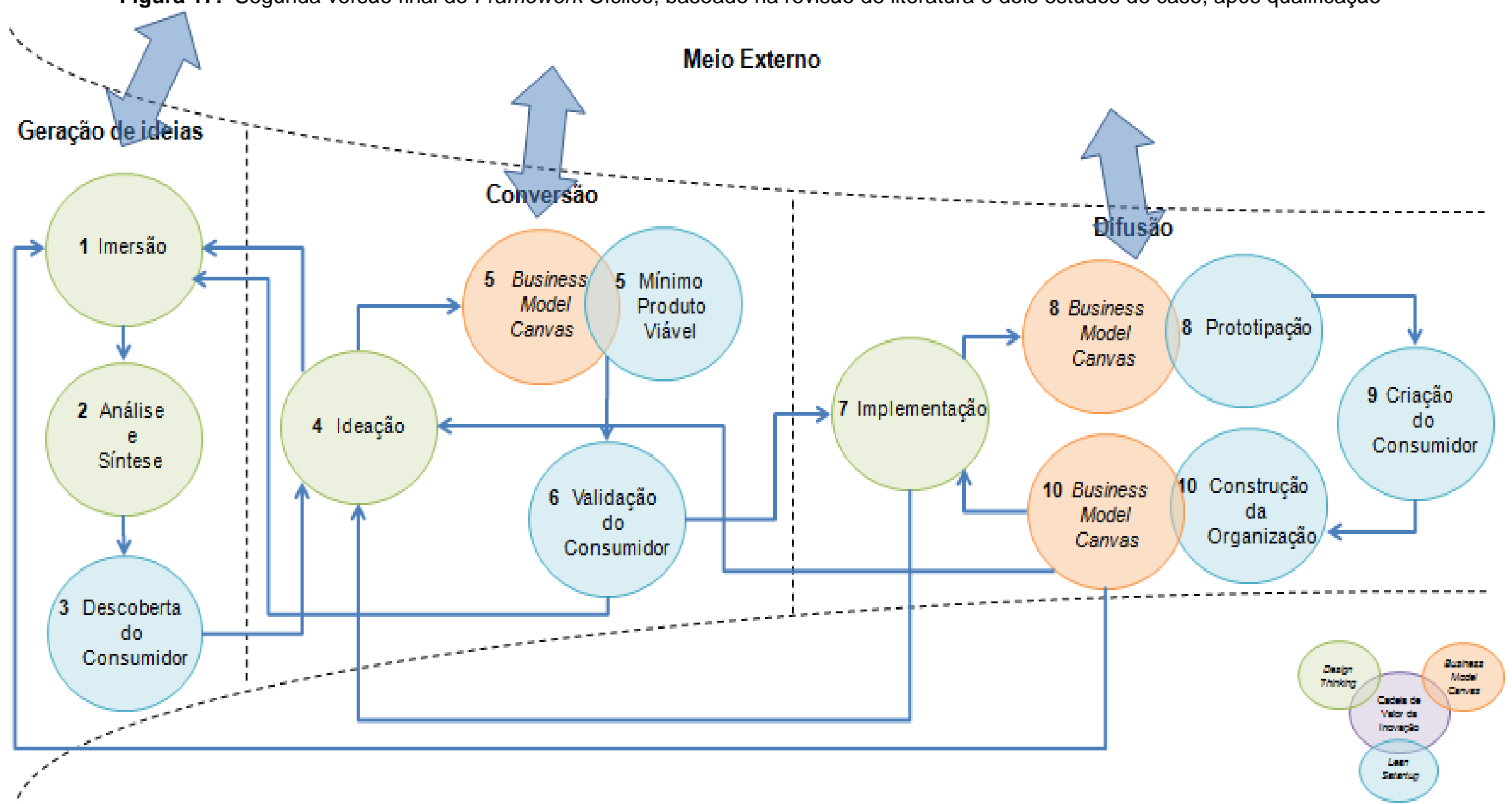

Fonte: Elaborado pela autora. 


\subsection{Realização do Painel de Especialistas e terceira versão do Framework Cíclico}

Nesta etapa do trabalho será detalhado o processo de realização do painel de especialistas, que contou com a participação de profissionais reconhecidos que atuam com startups, tendo em vista o aprimoramento da segunda versão do Framework Cíclico e dando origem à sua terceira versão.

\subsubsection{Análise dos resultados do Painel de Especialistas}

Conforme detalhado no item 3.2.1 o questionário aplicado no painel de especialistas foi desenvolvido com base na revisão de literatura sobre os assuntos de interesse desta pesquisa, sendo um aprimoramento do questionário do teste-piloto realizado com duas startups antes do processo de qualificação. No questionário buscou-se identificar aprimoramentos para a segunda versão do Framework.

Os resultados dos testes-piloto do questionário do painel de especialistas não resultaram em recomendações de alteração no questionário, que manteve assim sua estrutura original. Tendo em vista a análise dos questionários a escala de cinco pontos foi agrupada da seguinte maneira: as opções "muito relevante" e "relevante" foram classificadas como positivas; a opção "indiferente" como neutra; e as opções "pouco relevante" e "irrelevante" negativas. Este agrupamento foi realizado para facilitar a análise dos resultados obtidos e o estabelecimento de conclusões e direcionamentos.

Num segundo momento foram analisadas as questões abertas com a utilização de Análise Qualitativa, de forma que todas as respostas foram lidas buscando-se identificar padrões de informações relevantes para serem agregadas nas análises deste estudo, permitindo assim maior riqueza na validação do Framework Cíclico proposto.

O questionário foi enviado para 15 especialistas ligados à startups, dos quais 8 foram respondidos, viabilizando uma taxa de retorno de $53 \%$. A idade média dos respondentes é de 45 anos, variando de 26 à 59 anos. Todos os respondentes que retornaram o questionário são do sexo masculino. A média de anos de atuação junto à startups é de 14 anos, variando entre 3 e 30 anos. 
Os especialistas são profissionais conceituados em áreas como tecnologia, gestão do conhecimento, desenvolvimento de produtos e de softwares, inovação e empreendedorismo e, independentemente do seu contexto de origem, acabaram por se envolver, compreender a importância e assim aprofundaram sua vivência no universo das startups.

A seguir são apresentadas as perguntas e respostas obtidas.

Na sua opinião o processo de Geração de Ideias, ou seja, o desenvolvimento de novos conceitos inovadores para produtos e serviços, inclui apenas e necessariamente as etapas de Imersão, Análise e Síntese e Descoberta do Consumidor? Se não, quais etapas estão a mais? Sentiu falta de outras etapas?

Geração de Ideias - cinco dos especialistas acreditam que o processo de Geração de Ideias, ou seja, o desenvolvimento de novos conceitos inovadores para produtos e serviços, inclui apenas e necessariamente as etapas de Imersão, Análise e Síntese e Descoberta do Consumidor, conforme proposto no modelo. Outros três especialistas não acreditam que sejam apenas estas as etapas. Os especialistas que acreditam no processo de Geração de Ideias como proposto pelo Framework adicionariam elementos a esta fase, como a busca por vivenciar e identificar os gargalos do setor no qual se busca entrar, experimentando a Cadeia de Valor do setor tendo em vista a identificação de gargalos; a necessidade de se ter um objetivo ao final da fase, um output a ser buscado, algo como chegar à uma ideia plausível para a solução do problema do consumidor; e também ter um momento que desmistifique o empreendedorismo enquanto "uma festa".

Considerando os especialistas que acreditam em mais etapas na fase de Geração de Ideias, foram obtidas as seguintes considerações: dentro do processo de estruturação das startups existem outros momentos, nas demais fases, em que pode ocorrer a demanda por novas ideias; é impossível limitar as fases como o modelo propõe, podendo ser usado, mas não tomado como regra, mesmo porque outras atividades como análise de fornecedores, seleção prévia de materiais, prototipação, avaliação sumária de retorno, entre outras, também podem ser utilizadas como filtro para seguir em frente ou não; existem certos fatores como definições estratégicas, fatores e formas de condução do 
processo de inovação, que devem ser levados em consideração para a definição da melhor forma de gerenciar o processo de inovação, sendo que o processo de geração de ideias não deve ser apenas a geração de grande número de ideias.

Questões sobre as etapas específicas:

Imersão: busca o entendimento do ambiente, do mercado e dos segmentos de clientes de interesse; usualmente inclui ampla pesquisa sobre estes tópicos, aplicando técnicas como benchmarks, levantamento da voz do cliente, pesquisas bibliográficas, entre outros.

Pontos relevantes em relação a fase de Imersão:

Imersão - foi considerada como positiva por todos os respondentes. Os especialistas contribuíram buscando garantir maior atenção às observações e entrevistas, que devem ser em profundidade; levar em consideração não apenas os clientes ligados à rede de relacionamentos do empreendedor, mas também aqueles que se encontram no mercado, sendo os que realmente importam; além da relevância em estudar detalhadamente a Cadeia de Valor do negócio em que pretende fazer parte, entender e vivenciar o seu dia-a-dia.

Análise e Síntese: consolida as informações obtidas na Imersão e busca estabelecer padrões e conexões entre estas utilizando de técnicas como personas, mapa de empatia e jornada do usuário.

Pontos relevantes em relação a fase de Análise e Síntese:

Análise e Síntese - avaliada como positiva por 7 dos especialistas, sendo considerada como neutra apenas por um respondente. Um especialista declarou que a fase não dever ser exaustiva, levando em consideração a natureza evolutiva do empreendedor. O especialista que indicou a etapa como neutra sente falta de ver a aplicação desta etapa gerando resultados reais e, mesmo gostando da etapa, acredita que os seus resultados não sejam tão significativos dentro do processo de estruturação de uma startup. 
Descoberta do Consumidor: consiste em transformar a visão estabelecida para a solução na fase de "Análise e Síntese" numa série de hipóteses que serão testadas para verificação das reações dos consumidores e validação do seu real interesse.

Pontos relevantes em relação a fase de Descoberta do Consumidor:

Descoberta do Consumidor - considerada como positiva já que todos os especialistas assinalaram como "muito relevante". Como contribuição os especialistas mencionam que a captura do feedback dos clientes é de extrema importância; que os próprios empreendedores devem desenvolver dezenas de entrevistas com potenciais clientes reais, pois assim será possível realizar a efetiva descoberta do consumidor, não devendo-se terceirizar esta etapa; o volume e intensidade das entrevistas devem gerar movimento suficiente para dar velocidade ao empreendedor e o permitir passar para a próxima etapa, não devendo ser um gargalo.

Na sua opinião o processo de Conversão, ou seja, transformação dos conhecimentos estruturados em resultados inovadores, é composta apenas e necessariamente pelas etapas de Ideação, Mínimo Produto Viável e Validação do Consumidor? Se não, quais etapas estão a mais? Sentiu falta de outras etapas?

Conversão - cinco especialistas consideram que nesta fase existem efetivamente apenas as etapas de Ideação, Produto Mínimo Viável e Validação do Consumidor. Um dos especialistas acredita que já neste momento cabe ao empreendedor pensar em questões como a construção do time da startup e desenhar o seu modelo de negócios. Outro especialista mencionou que nesta fase cabe a definição da arquitetura inicial do negócio, bem como a criação de sua especificação técnica e de seu layout, entre outros pontos. Para outro a visão proposta pelo Framework é útil, mas não acredita que seja possível o desenho de como deve ser esta trajetória única do empreendedor, não conseguindo visualizar divisões claras entre as fases e etapas do Framework. 
Ideação: busca a geração e refinamento das primeiras ideias, permitindo o teste das ideias aplicando técnicas como brainstorming, cardápio de ideias, matriz de posicionamento, etc.

Pontos relevantes em relação a fase de Ideação:

Ideação - etapa considerada como positiva pela maioria (sete respostas), porém sendo classificada como neutra por um especialista que acredita que o refinamento da ideia do empreendedor é obtido de forma mais relevante com entrevistas e validações com usuários reais, capazes de gerar bons insights; este especialista teme que da forma como está apresentada a atividade distancie o empreendedor do usuário em foco. Como contribuição apresentadas pelos outros especialistas vale destacar a aplicação de diferentes técnicas de geração de ideias que devem ser criteriosamente selecionadas, de forma a garantir a manutenção apenas das melhores.

Produto Mínimo Viável: construção de protótipo de baixa ou alta fidelidade e que incorpora as principais funções definidas como relevantes pela startup, de forma a permitir um primeiro teste das hipóteses elaboradas pelo empreendedor até o momento.

Pontos relevantes em relação a fase de Mínimo Produto Viável:

Produto Mínimo Viável - classificada como positiva por todos os especialistas, que a consideram como "muito relevante". Como pontos de contribuição temos a importância de se ter algo tangível para ser testado; a grande dificuldade em definir o que é mínimo. Um especialista considera este ponto como central do Framework, onde o empreendedor deve experimentar um processo de aprendizagem baseado em experimentos de teste e validação, que muitas vezes não implica necessariamente em construir algo.

Business Model Canvas: plano de negócios dinâmico que envolve de forma macro as etapas de: Segmentos de Consumo, Proposição de Valor, Canais, Relação com o Consumidor, Fontes de Receitas, Recursos Chave, Atividades Chave, Parcerias Chave e Estrutura de Custos.

Na sua opinião a etapa de Business Model Canvas em conjunto com o Produto Mínimo Viável é: 
Business Model Canvas em conjunto com o Produto Mínimo Viável neste momento, tratado de forma isolada, foi considerada como positiva por sete dos especialista e como neutra por um. Quando considerando o Business Model Canvas em conjunto com o Produto Mínimo Viável o resultado foi o mesmo. Quanto às contribuições apresentadas vale destacar a necessidade de compreender como o modelo de negócios será escalável. O especialista que anotou "indiferença" acredita que ainda seja cedo para a aplicação do Business Model Canvas, pois o considera muito complexo para este momento e propõe para esta etapa apenas a utilização do Canvas do Value Proposition Design viabilizando maior aproximação com o problema analisado. Um dos especialistas acredita que este momento deve ser mais orientado para 0 consumidor, com foco neste e, como o Business Model Canvas tem orientação organizacional não seja tão recomendado.

Validação do Consumidor: busca aprender mais sobre o público de interesse e para isto apresenta o Produto Mínimo Viável e realiza testes de aceitação junto aos consumidores potenciais.

Pontos relevantes em relação a fase de Validação do Consumidor:

Validação do Consumidor - considerada como positiva por todos os especialistas. Um dos especialistas acredita que o modelo deve incorporar neste ponto uma nova seta em direção aos momentos de Ideação e de Imersão; outro especialista acredita que o desafio neste momento é a determinação de uma amostra significativa para validação.

Na sua opinião o processo de Difusão, primeira comercialização do produto, serviço ou processo, é composto apenas e necessariamente pelas etapas de Implementação, Prototipação, Criação do Consumidor e Construção da Organização? Se não, quais etapas estão a mais? Sentiu falta de outras etapas?

Difusão - cinco dos especialistas concordaram que esta fase é apenas composta pelas etapas de Implementação, Prototipação, Criação do Consumidor e Construção da Organização, mas três especialistas discordaram desta afirmação. Um especialista menciona a importância da criação do 
consumidor tendo em vista o início das vendas; outros dois especialistas acreditam que são tantas as etapas neste momento que fica impossível uma listagem única, já que se verifica alta complexidade na passagem do protótipo para o produto final, mesmo que ainda em baixa escala, além de que a construção da organização é um grande momento de complexa burocratização organizacional. Um último especialista acredita que neste momento deve-se ter uma validação e confirmação de tudo que foi desenvolvido até o momento.

Implementação: tem como foco viabilizar o estabelecimento da operações da startup, incluindo a finalização dos seus produtos e serviços e início das transações com os segmentos de clientes de interesse.

Pontos relevantes em relação a fase de Implementação:

Implementação - considerada como positiva por todos os especialistas, sendo que um deles mencionou que a considera como etapa mais importante. Não foram apresentadas considerações adicionais.

Prototipação: com base nos resultados obtidos com os testes do Produto Mínimo Viável esta etapa tem por objetivo viabilizar uma primeira versão comercial do produto e/ou serviço que será oferecido ao mercado.

Pontos relevantes em relação a fase de Prototipação:

Prototipação - também considerada como positiva por todos os respondentes. Em relação às considerações um especialista mencionou que a prototipação no Framework ocorre em apenas um momento e considera que eventualmente existiriam outros momentos necessários. Outro especialista considerou que é preciso uma boa separação entre os conceitos de Produto Mínimo Viável e Prototipação, ligando esta última com a elaboração dos primeiros projetos.

Business Model Canvas: plano de negócios dinâmico que envolve de forma macro as etapas de: Segmentos de Consumo, Proposição de Valor, Canais, Relação com o Consumidor, Fontes de Receitas, 
Recursos Chave, Atividades Chave, Parcerias Chave e Estrutura de Custos.

Pontos relevantes em relação a fase de Business Model Canvas em conjunto com a Prototipação:

Business Model Canvas em conjunto com a Prototipação - classificada como positiva por seis dos especialistas e como neutra por dois especialistas. Para um dos especialistas a elaboração do Modelo de Negócios deveria ser iniciada antes. Um segundo especialista acredita que é de extrema relevância o uso do Business Model Canvas neste momento, reforçando que no momento anterior empregaria apenas o Canvas do Value Proposition Design.

Criação do Consumidor: tem como foco realizar as primeiras vendas efetivas do produto e/ou serviço, confirmando se a proposta de valor efetivamente resolve a questão do consumidor.

Pontos relevantes em relação a fase de Criação do Consumidor:

Criação do Consumidor - considerada como positiva por todos os especialistas. Em relação às considerações apresentadas um dos especialistas menciona que neste momento é essencial ocorrer venda e outro especialista considera que podem ser desenvolvidos itens que futuramente não serão necessariamente escaláveis, mas que são muito importantes neste momento.

Construção da Organização: Busca estabelecer todos os demais aspectos para operacionalização da startup, incluindo a aquisição dos recursos principais, desenvolvimento de parcerias e estabelecimento das atividades produtivas.

Pontos relevantes em relação a fase de Construção da Organização:

Construção da Organização - considerada como positiva por todos os especialistas. Em relação às considerações um dos especialistas menciona que cabe a determinação do time que irá compor a organização e outro especialista menciona que é o melhor momento para o empreendedor, sendo 0 momento em que pode visualizar seu negócio em si. 
Business Model Canvas: plano de negócios dinâmico que envolve de forma macro as etapas de: Segmentos de Consumo, Proposição de Valor, Canais, Relação com o Consumidor, Fontes de Receitas, Recursos Chave, Atividades Chave, Parcerias Chave e Estrutura de Custos.

Pontos relevantes em relação a fase de Business Model Canvas em conjunto com a Construção da Organização:

Business Model Canvas em conjunto a Construção da Organização considerado como positivo por cinco dos especialistas, neutro por dois e negativo por um. Para um dos especialista o BMC deve ser utilizado apenas com protótipos. Outro especialista acredita que o BMC deve ser desenvolvido apenas neste momento, quando existe o desejo de ir para o mercado buscar por investidores. Um segundo especialista acredita que este ponto do Framework ficou confuso e menciona que substituiria por um "Plano de Produto e de Crescimento", pois assim as startups poderiam ter clareza quanto aos estágios de evolução dos seus produtos, de forma que não fiquem muito tempo apenas no campo de ideias, além de poder visualizar as estratégias de crescimento. Para um quarto especialista o BMC pode orientar a estruturação de um plano de captação financeira, valendo pensar como será a captação de recursos financeiros para o negócio.

Com todas as observações dos especialistas foi possível então aprimorar a proposta do Framework Cíclico e chegar a sua nova versão, apresentada no próximo item desta dissertação.

\subsubsection{Terceira versão do Framework Cíclico}

Neste momento do estudo foi realizada a revisão do Framework apresentado na Figura 17 incorporando as considerações obtidas no painel de especialistas relacionados á startups. A Figura 18 apresenta esta nova versão. Em termos de etapas propostas a única mudança foi a substituição no uso do Business Model Canvas em conjunto com o Produto Mínimo Viável pelo uso do Canvas do Value Proposition Design, detalhada dentro da fase de Conversão. 
Figura 18: Terceira versão do Framework Cíclico com base no painel de especialistas em startups

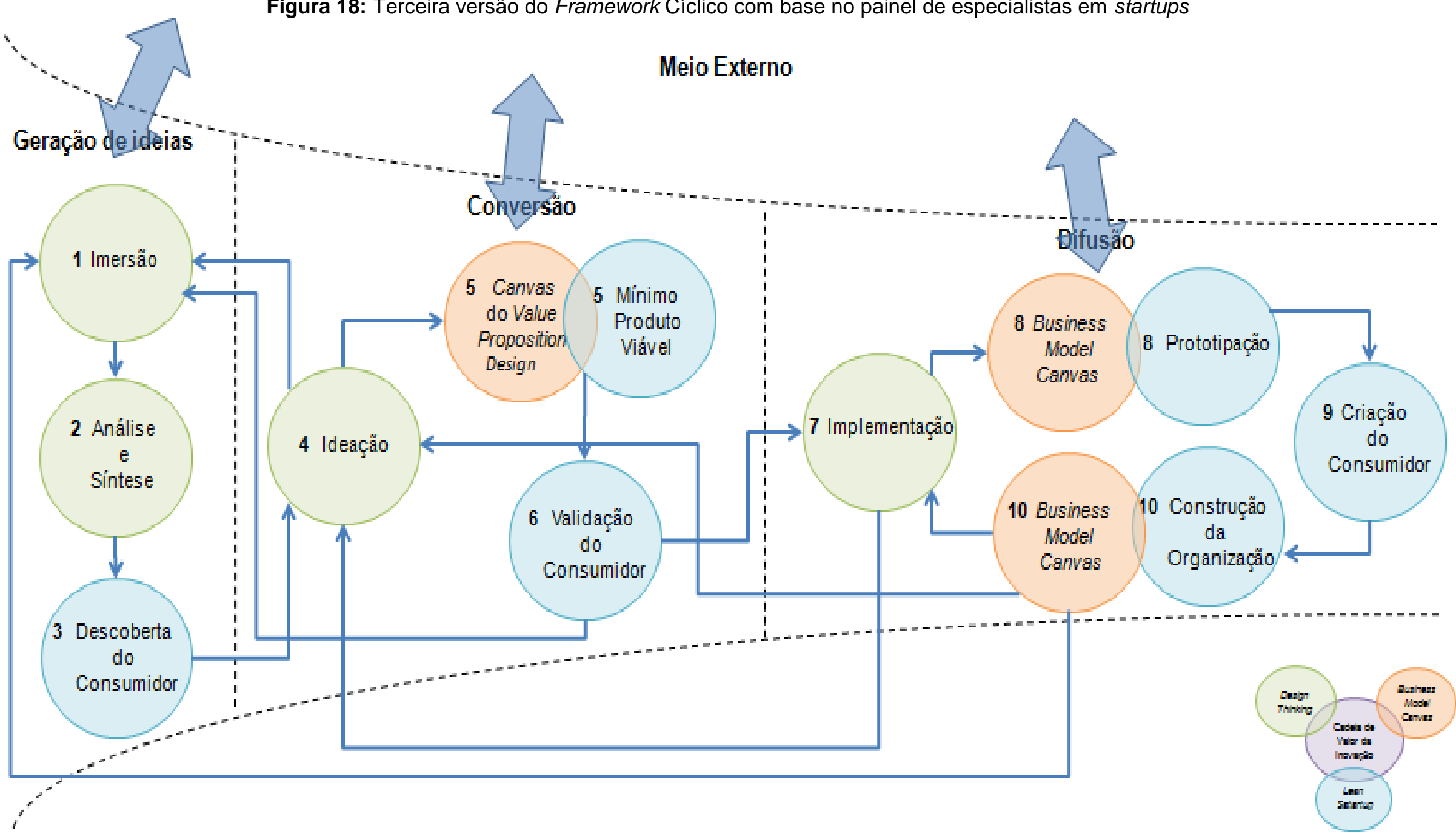

Fonte: Elaborado pela autora. 
De forma a incorporar as considerações apresentadas anteriormente 0 detalhamento da Figura 18 é o seguinte:

- Geração de ideias - considerando a fase de Imersão do Design Thinking, visa um mergulho profundo para a geração das ideias, envolvendo a busca por entrevistas e observações no contexto de interesse. Na etapa de Descoberta do Consumidor do Lean Startup é importante ressaltar a importância do próprio empreendedor ir a campo fazer entrevistas e entender em profundidade os consumidores potenciais, pois esta não é uma tarefa que deva ser terceirizada, sendo de extrema importância para o sucesso da startup que ainda está em processo de estruturação. Neste momento é necessário que o empreendedor seja flexível, já que não existe uma fórmula única para identificar quantas pessoas entrevistar, sendo necessário que este identifique quando sua curva de aprendizagem deixa de evoluir ou passa a apresentar evolução mínima. Outro ponto importante é ter dinamismo nas entrevistas.

Ao final desta fase sugere-se que o empreendedor tenha a real ideia do problema que será resolvido. É preciso ter cuidado para que a etapa não se torne exaustiva, garantindo o dinamismo necessário para o empreendedor. Vale destacar que sempre que o empreendedor considerar necessário deve realizar esta etapa novamente tendo em vista a obtenção de novas ideias em momentos mais avançados da estruturação do empreendimento.

- Conversão - na fase de Ideação do Design Thinking sugere-se que o empreendedor atue efetivamente na área de interesse de forma a vivenciar este ambiente e identificar gargalos que podem se transformar em oportunidades de interesse, possibilitando um mergulho no contexto do funcionamento do tipo de negócio e de sua Cadeia de Valor, permitindo o conhecimento de questões relacionadas com fornecedores, materiais e questões estratégicas. Quando não for possível atuar no setor é preciso um mergulho profundo eventualmente utilizando mídias sociais e conversas com pessoas que entendem do setor, de forma que o empreendedor seja capaz de realizar uma avaliação preliminar do retorno esperado. 
Para o Produto Mínimo Viável proposto pelo Lean Startup é preciso desenvolver algo tangível, que possa ser testado com o objetivo maior de viabilizar a aprendizagem baseada em experimentação e validação, sendo de suma importância que, antes de seu desenvolvimento, seja definido o que será realizado nos testes.

Com o Produto Mínimo Viável validado deve-se iniciar o planejamento da organização, estabelecendo sua arquitetura inicial, suas primeiras especificações técnicas, identificando o time de trabalho, como será o layout do produto ou do serviço que se pretende ofertar ao mercado, além de planejar os relacionamentos estabelecidos na Cadeia de Valor em que será inserido o negócio. Neste momento vale estruturar o Canvas do Value Proposition Design buscando um melhor entendimento do consumidor, a compreensão do seu perfil e como será criado o valor, estabelecendo a arquitetura das hipóteses que serão validadas (ou não) pelos consumidores potenciais.

$\mathrm{Na}$ Validação do Consumidor proposta pelo Lean Startup, vale destacar a relevância de identificar o momento em que o Produto Mínimo Viável pode ser considerado como validado, ou seja, quando os consumidores deixam de agregar ideias sobre melhorias significativas e a curva de aprendizagem estabilizou ou passou a evoluir lentamente mesmo após contato com vários potenciais clientes. Neste momento ainda é essencial que o próprio empreendedor faça entrevistas de validação junto a consumidores potencias, não devendo de forma alguma se distanciar destes. Também deve-se buscar as vendas, de forma a validar ou não o que foi desenvolvido até o momento.

- Difusão - considerando a atividade de Prototipação vale destacar que poderão ser desenvolvidos protótipos que não necessariamente serão escaláveis, mas que serão bastante importantes no processo de desenvolvimento do produto final. $\mathrm{Na}$ Construção da Organização, é muito importante garantir atenção ao desenvolvimento do time. 
Dando continuidade ao processo de aprimoramento do Framework Cíclico, este foi submetido a uma survey junto á empreendedores de startups de sucesso tendo em vista quatro objetivos principais:

- Validar a estrutura proposta neste Framework.

- Identificar o grau de relevância das etapas propostas pelo Framework de acordo com os empreendedores.

- Identificar as etapas efetivamente realizadas pelos empreendedores das startups de sucesso.

- Identificar quais etapas são recomendadas pelos empreendedores para serem realizadas novamente em outros contextos.

\subsection{Survey junto aos empreendedores de Startups}

A última etapa proposta para este estudo consistiu na aplicação de uma survey junto à idealizadores de startups de sucesso (mais de um ano de existência), que estão passando ou passaram por processo de aceleração em aceleradoras brasileiras. $O$ resultado obtido com esta iniciativa contribuiu para o estabelecimento da versão final do Framework Cíclico com a identificação das práticas utilizadas pelos empreendedores e na consolidação de um grupo de práticas apontadas por estes enquanto recomendadas e relevantes para startups que busquem alcançar o sucesso. A quarta e versão final do Framework Cíclico será apresentada no item 5 deste estudo.

\subsubsection{Análise dos resultados da Survey}

Conforme já relatado no item 3.3.2 desta pesquisa, os testes-piloto da survey consistiram no envio por meio virtual de questionário para 2 empreendedores de startups buscando validar a adequação da linguagem empregada e também o atendimento das necessidades desta pesquisa tendo em vista a obtenção dos objetivos propostos.

Em relação aos resultados obtidos com a aplicação dos testes-piloto, os respondentes contribuíram com a proposta de incluir, além de questionamentos sobre a frequência de realização das etapas (já apresentado anteriormente), o questionamento sobre a recomendação ou não pelo empreendedor em relação à realização ou não da etapa em consideração. Este ponto foi considerado 
como relevante e incluso no questionário com as seguintes opções de respostas: "sim, recomendo" ou "não, não recomendo".

Buscando validar o Framework após as mudanças estruturadas a partir dos resultados obtidos com a aplicação do painel de especialistas e dos testes-piloto, a survey foi aplicada junto a empreendedores de startups de sucesso, cuja amostragem foi selecionada seguindo os critérios já relatados no item 3.3.3 deste documento.

Desta maneira foram contatados 856 empreendedores e destes 88 respondentes participaram da pesquisa, resultando numa taxa de retorno de 10,3\% em relação à amostra selecionada. Considerando a representatividade em relação à população de startups aceleradas ou em processo de aceleração o resultado obtido foi de $8 \%$.

Considerando os resultados obtidos a base foi ajustada e validada e, como um dos respondentes não respondeu nenhuma pergunta antes de encerrar sua participação, suas respostas foram descartadas. Assim a representatividade final desta survey ficou em 10,1\% considerando a amostragem selecionada e em $7,9 \%$ considerando a população total de startups aceleradas ou em processo de aceleração por aceleradoras brasileiras.

Os respondentes desta pesquisa apresentaram idade média de 34 anos, com variação entre 22 e 61 anos. Em relação à escolaridade dos respondentes a maioria são graduados (40\%), porém vale destacar o número de respondentes com pós-graduação (24\%) e mestrado (23\%) (ver Gráfico 2). Dos respondente $90 \%$ são do gênero masculino e $10 \%$ do gênero feminino.

Gráfico 2: Escolaridade dos empreendedores de startups de sucesso

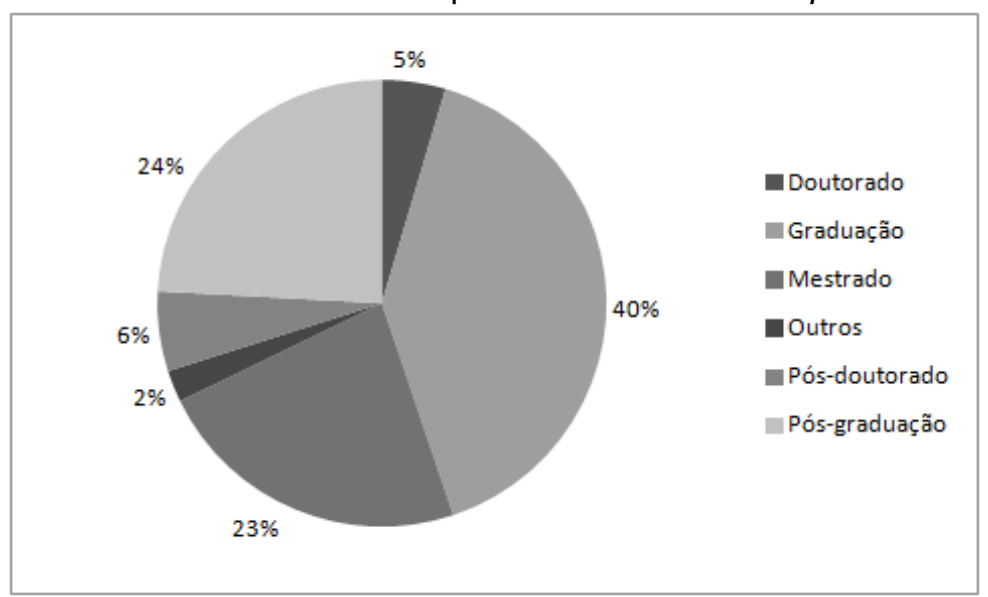

Fonte: Elaborado pela autora. 
Em relação a quantidade de anos atuando como empreendedor a média obtida foi de 7 anos, com tempos variando entre 1 e 30 anos, valendo destacar que $16 \%$ atua a 3 anos e $13 \%$ atua a 2 anos; as demais frequências estão semelhantemente distribuídas. A média do número de startups em que os respondentes já atuaram é de 2, com variabilidade entre 1 e 7 . Entre os respondentes 53\% atuou apenas em uma startup e $24 \%$ em duas. Em relação aos anos de atuação na startups atual a média foi de 4 anos, variando entre $1 \mathrm{e}$ 20 anos. Na amostra $24 \%$ atua a um ano apenas e $23 \%$ a dois anos. Em relação aos anos de existência da startup em que o respondente atua a média é de 4 anos, variando entre 1 e 20 anos, valendo destacar que $23 \%$ existe a 2 anos e $21 \%$ existe a 3 anos.

A análise dos resultados da survey consistiu em três etapas:

1 - Aplicação de Estatística Descritiva, originando um sumário estatístico da survey;

2 - Uso de Análise Fatorial, buscando padrões e assim a determinação do conjunto de etapas ideais para as fases do Framework;

3 - Uso de Análise Qualitativa, que contribuiu em relação às respostas das questões abertas, buscando evidências complementares.

\subsubsection{Resultados Descritivos}

Para a análise dos questionários inicialmente foi realizada a análise das questões estruturadas tendo como objetivo estabelecer uma primeira medição e entendimento em relação à amostra dos empreendedores das startups que participaram deste estudo. A seguir foi realizada contagem buscando medir a frequência com que as etapas propostas pelo Framework Cíclico são efetivamente utilizadas, e, finalmente, foi realizada a contagem em relação à recomendação das etapas propostas pelos empreendedores.

A frequência em relação ao total na utilização de cada etapa proposta foi medida com o intuito de se ter uma primeira percepção da utilidade de cada etapa, bem como do seu grau de recomendação. Classificou-se como "uso" quando o idealizador da startup assinalou a opção "em todos os projetos" ou a opção "na maioria dos projetos" e como recomendação quando o respondente sinalizou "Sim, recomendo". Os resultados são apresentados na Tabela 2. 
Tabela 2: Uso e recomendação das etapas do Framework Cíclico para os empreendedores de startups

\begin{tabular}{|c|c|c|c|c|}
\hline & \multicolumn{2}{|c|}{$\begin{array}{c}\text { Uso das etapas } \\
\text { propostas pelo } \\
\text { Framework }\end{array}$} & \multicolumn{2}{|c|}{$\begin{array}{l}\text { Recomendação das } \\
\text { etapas propostas pelo } \\
\text { Framework }\end{array}$} \\
\hline & Frequência & $\%$ & Frequência & $\%$ \\
\hline \multicolumn{5}{|l|}{ Geração de Ideias } \\
\hline 1 Imersão & 71 & $82 \%$ & 85 & $98 \%$ \\
\hline 2 Análise e Síntese & 62 & $71 \%$ & 78 & $90 \%$ \\
\hline 3 Descoberta do Consumidor & 64 & $74 \%$ & 79 & $91 \%$ \\
\hline \multicolumn{5}{|l|}{ Conversão } \\
\hline 4 Ideação & 65 & $75 \%$ & 78 & $90 \%$ \\
\hline 5.1 Produto Mínimo Viável & 68 & $78 \%$ & 85 & $98 \%$ \\
\hline $\begin{array}{l}\text { 5.2 Canvas do Value Proposition } \\
\text { Design }\end{array}$ & 47 & $54 \%$ & 76 & $87 \%$ \\
\hline 6 Validação do Consumidor & 67 & $77 \%$ & 84 & $94 \%$ \\
\hline \multicolumn{5}{|l|}{ Difusão } \\
\hline 7 Implementação & 66 & $76 \%$ & 83 & $95 \%$ \\
\hline 8.1 Prototipacão & 66 & $76 \%$ & 83 & $95 \%$ \\
\hline 8.2 Business Model Canvas & 53 & $61 \%$ & 77 & $89 \%$ \\
\hline 9 Criação do Consumidor & 60 & $69 \%$ & 81 & $93 \%$ \\
\hline 10.1 Construção da Organização & 61 & $70 \%$ & 83 & $95 \%$ \\
\hline 10.2 Business Model Canvas & 53 & $61 \%$ & 77 & $89 \%$ \\
\hline
\end{tabular}

Fonte: Elaborado pela autora.

Para a análise dos dados foi gerada a Tabela 3 com utilização do software SPSS Statistics 20, apresentando a média, o desvio padrão e o número de respostas para cada uma das etapas propostas no Framework Cíclico e o seu efetivo uso. A média foi utilizada para caracterizar a tendência central da amostra. Já o desvio padrão foi utilizado para verificar a variação existente em relação a média.

Tabela 3: Estatística Descritiva para as etapas do Framework Cíclico em relação às respostas dos empreendedores de startups

\begin{tabular}{|l|r|r|r|}
\hline & N & Mean & Std. Deviation \\
\hline Imersão & 87 & 4,09 & 1,019 \\
Análise_e_Síntese & 87 & 3,85 & 1,215 \\
Descoberta_do_Consum & 87 & 3,98 & 1,191 \\
idor & & & \\
Ideação & 87 & 3,95 & 1,247 \\
Produto_Mínimo_Viável & 87 & 4,26 & 1,105 \\
Canvas_do_Value_Propo & 87 & 3,43 & 1,344 \\
sition_Design & & & \\
Validação_do_Consumid & 87 & 4,08 & 1,193 \\
or & 87 & 4,17 & 1,059 \\
Implementação & 87 & 4,01 & 1,307 \\
Prototipação & 87 & 3,59 & 1,411 \\
Business_Model_Canvas & 87 & 3,91 & 1,335 \\
Criação_do_Consumidor & 87 & 3,93 & 1,218 \\
Construção_da_Organiza & & & 1,443 \\
ção & 87 & 3,18 & \\
Business_Model_Canvas & & & \\
-2 & & & \\
Valid N (listwise) & & & \\
\hline
\end{tabular}

Fonte: Gerado no SPSS. 
Observando as estatísticas obtidas em relação ao uso das etapas do Framework pode-se perceber médias elevadas, que vão desde 3,18 á 4,26 (sendo o máximo de 5); já o desvio padrão apresentou valores entre 1,019 á 1,443, não apresentando elevação significativa. Em linhas gerais os resultados apresentados podem ser considerados como bastante positivos em relação aos objetivos desta pesquisa uma vez que, com as médias elevadas e desvios padrão razoavelmente reduzidos, é possível afirmar que as etapas propostas são significativas, garantindo o alinhamento do Framework Cíclico proposto neste estudo com a realidade verificada na prática. Uma vez com as análises descritivas da amostra estruturadas e tendo sido obtido melhor entendimento sobre o uso e recomendação das etapas propostas pelo Framework passou-se à próxima etapa do estudo, a Análise Fatorial.

\subsubsection{Análise com Análise Fatorial}

Neste estudo foram aplicadas técnicas de Estatística Multivariada, mais especificamente de Análise Fatorial. A Análise Fatorial busca verificar padrões de relação entre as etapas propostas pelo Framework e, assim, determinar a composição ideal de suas fases, além de ter a capacidade de identificar e organizar a inter-relação de variáveis e determinar o padrão de relacionamento entre estas. A opção pelo uso da Análise Fatorial ocorreu porque esta ferramenta permite o estudo considerando diversas variáveis, enquanto que a Análise Univariada permite considerar apenas uma variável

Segundo Hair et al. (2010), Análise Fatorial pode ser definida como uma técnica para análise de padrões complexos, podendo ser utilizada na busca de padrões de relacionamentos entre um amplo conjunto de variáveis e na determinação sobre quando a informação pode ser condensada ou sumarizada em pequenos conjuntos de fatores ou componentes. A Análise Fatorial permite identificar e organizar a estrutura das inter-relações (correlações) de um amplo número de variáveis, estabelecendo conjuntos de variáveis que apresentam-se amplamente inter-relacionadas, conhecidas como fatores; estes grupos de variáveis (fatores) representam as dimensões dos dados e são escolhidos por sintetizarem o comportamento de outras variáveis (HAIR et al., 2010).

Segundo Tabachnick e Fidell (2012) o objetivo da Análise Fatorial é sumarizar padrões de correlação entre as variáveis observadas, transformando 
estas variáveis em fatores, viabilizando o estabelecimento de uma definição operacional (equação de regressão) sobre um fenômeno, utilizando variáveis observadas ou testes de teorias relacionados com a natureza do processo. Para Hair et al. (2010), as etapas de uma Análise Fatorial incluem a especificação da unidade de análise, o desenvolvimento da sumarização e/ou redução dos dados, a seleção da variável e a utilização dos seus resultados combinados com outras técnicas multivariadas.

Ainda segundo Hair et al. (2010) deve-se realizar a escolha do design da Análise Fatorial, podendo-se optar pelas opções de R-type ou Q-type. A primeira opção (R-type) utiliza uma matriz de correlação tradicional e a segunda opção (Q-type) trabalha a correlação entre as respostas dos respondentes. No caso deste estudo será utilizada a opção $R$-type, já que no contexto em análise não se faz necessário o cálculo da correlação entre os respondentes.

Como as variáveis assinaladas pelos respondentes não são numéricas tornou-se necessária a sua transformação numérica (HAIR et al., 2010) aplicando a seguinte escala: "em todos os projetos" = 5; "na maioria dos projetos" = 4; "em cerca de metade dos projetos" = 3; "em poucos projetos" = 2 ; e "em nenhum projeto" = 1 .

Em relação à interpretação sobre as variáveis e suas correlações a Tabela 4 apresenta os valores utilizados neste estudo. Para efetiva continuidade as variáveis devem apresentar coeficiente de correlação superior a 0,30 pois, caso contrário, a relação de interdependência será muito tênue para permitir resultados que possam ser considerados como satisfatórios.

Tabela 4: Interpretação do coeficiente de correlação

\begin{tabular}{c|l}
\hline Valor de $\boldsymbol{p}(+\mathbf{~ o u}-)$ & \multicolumn{1}{c}{ Interpretação } \\
\hline 0.00 a 0.19 & Correlação bem fraca \\
\hline 0.20 a 0.39 & Correlação fraca \\
\hline 0.40 a 0.69 & Correlação moderada \\
\hline 0.7010 .89 & Correlação forte \\
\hline 0.90 a 1.00 & Correlação muito forte \\
\hline \multicolumn{2}{c}{ Fonte: Elaborado pela autora. }
\end{tabular}

Segundo Hair et al. (2010), uma vez que as variáveis foram especificadas e a matriz de correlação estiver preparada, chega-se ao momento de efetivamente aplicar a Análise Fatorial e, para iniciar esta análise, 
é preciso decidir em relação a rotação. Segundo Hair et al. (2010) a rotação pode ser Ortogonal ou Obliqua; neste estudo será utilizada a rotação Ortogonal por ser utilizada mais frequentemente e também pelo fato de que os processos de análise utilizando a rotação Obliqua ainda são considerados pouco desenvolvidos, gerando algumas controvérsias (HAIR et al., 2010). A abordagem Ortogonal utilizada é a VARIMAX, pois oferece o máximo de simplificação possível, além de ser bem sucedida enquanto abordagem analítica para a rotação Ortogonal dos fatores (HAIR, et al., 2010).

Uma vez com os resultados obtidos na matriz proveniente da Análise Fatorial deve-se proceder à análise da correlação dos fatores e a sinalização dos fatores de maior representatividade. Na tabela com a rotação ainda será possível visualizar as comunalidades (que sumarizam estatisticamente o quão bem as variáveis são explicadas pelos componentes), que devem então ser simplificadas, permitindo uma melhor visualização dos fatores mais importantes que devem ser rotacionados.

Considerando-se os resultados apresentados na Tabela 5 verifica-se apenas um caso de correlação forte, entre Imersão e Análise e Síntese $(0,712)$, diversas com correlação moderada e fraca e alguns casos com correlação bem fraca ou mesmo negativa, a Tabela 4 apresenta os critérios norteadores para a interpretação. 
Tabela 5: Matriz de correlação das etapas propostas pelo Framework Cíclico em relação às respostas dos empreendedores de startups

\begin{tabular}{|c|c|c|c|c|c|c|c|c|c|c|c|c|c|c|}
\hline & & Imersåo & $\begin{array}{c}\text { Análise_e_si } \\
\text { ntesese }\end{array}$ & $\begin{array}{l}\text { Descoberta_d } \\
\text { 0_Consumid } \\
\text { of }\end{array}$ & Ideaçăo & $\begin{array}{c}\text { Produto_Mini } \\
\text { mo_Viável }\end{array}$ & $\begin{array}{l}\text { Canvas_do_V } \\
\text { alue_Proposit } \\
\text { ion_Design }\end{array}$ & $\begin{array}{l}\text { Validação_do } \\
\text { Consumidor }\end{array}$ & $\begin{array}{c}\text { Implementaç } \\
\text { äo }\end{array}$ & Protototipąăa & $\begin{array}{l}\text { Business_Mo } \\
\text { del_Canvas }\end{array}$ & $\begin{array}{l}\text { Crią̧áado_do- } \\
\text { Consumidor }\end{array}$ & $\begin{array}{l}\text { Construçáa_d } \\
\text { a_organizaçă â } \\
0\end{array}$ & $\begin{array}{l}\text { Business_Mo } \\
\text { del_Canvas_ } \\
2\end{array}$ \\
\hline \multirow[t]{13}{*}{ Correlation } & Imersão & 1,000 & .712 & .579 & 5.282 & 2.253 & .191 & 198 & $\begin{array}{l}.057 \\
\end{array}$ & 5.149 & .161 & 5.179 & .240 & $5 ., 218$ \\
\hline & Análise_e_Sintese &, 712 & 1,000 & ,493 &, 327 & .224 & \begin{tabular}{|l|l|}
.174 \\
\end{tabular} & \begin{tabular}{|l|l|}
0.079 \\
\end{tabular} & 0,102 & \begin{tabular}{|l|l|}
.091 \\
\end{tabular} & 0.167 & 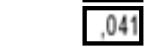 & \begin{tabular}{|l|l|}
.182 \\
\end{tabular} & 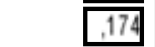 \\
\hline & $\begin{array}{l}\text { Descoberta_do_Consum } \\
\text { idor }\end{array}$ & .579 & .493 & 1,000 & .362 & 349 & 0.149 & 371 & 0,002 & .122 & 329 & 2.251 & \begin{tabular}{|l|l|}
.233 \\
\end{tabular} & .383 \\
\hline & Ideaçåa & \begin{tabular}{|r|}
282 \\
\end{tabular} & .327 & .362 & 1,000 & .249 & .126 & \begin{tabular}{|c|}
.279 \\
\end{tabular} & .000 & .16 & .217 & .219 & .320 & \begin{tabular}{|c|}
.28 \\
\end{tabular} \\
\hline & Produto_Minimo_Viàvel & \begin{tabular}{|l|}
253 \\
\end{tabular} & .224 & .349 & .249 & 1,000 & \begin{tabular}{|r|}
.202 \\
\end{tabular} &., 474 & \begin{tabular}{|l|l|}
.046 \\
\end{tabular} &, 342 & 0.063 &, 379 & .260 & \begin{tabular}{|l|l|}
179 \\
\end{tabular} \\
\hline & $\begin{array}{l}\text { Canvas_do_Value_Propo } \\
\text { sition_Design }\end{array}$ & 191 & .174 & .149 & \begin{tabular}{|c|}
126 \\
\end{tabular} & .202 & 1,000 & .164 & 1,182 & .201 &, 524 & .216 & \begin{tabular}{|l|l|}
.165 \\
\end{tabular} & .496 \\
\hline & $\begin{array}{l}\text { Validaąäo_do_Consumid } \\
\text { of }\end{array}$ & .198 & \begin{tabular}{|l|l|}
079 \\
\end{tabular} & ,371 &., 27. & , 474 & \begin{tabular}{|l|l|}
164 \\
\end{tabular} & 1,000 & .272 & ,304 & .248 &, 662 & .158 & \begin{tabular}{|c|}
263 \\
\end{tabular} \\
\hline & Implementaçăo & \begin{tabular}{|l|}
057 \\
\end{tabular} & \begin{tabular}{|l|l|}
102 \\
\end{tabular} & .002 & .007 & .046 & \begin{tabular}{|l|l|}
.182 \\
\end{tabular} & .272 & 1,000 & ,314 & .133 & .247 & .429 & 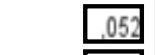 \\
\hline & Prototipaçăo & \begin{tabular}{|l|l|}
148 \\
\end{tabular} & \begin{tabular}{|l|}
091 \\
\end{tabular} & \begin{tabular}{|l|l|}
125 \\
\end{tabular} & \begin{tabular}{|l|l|}
163 \\
\end{tabular} & 342 & .201 & 304 & 314 & 1,000 & .066 &, 351 & \begin{tabular}{|l|}
.281 \\
\end{tabular} & .122 \\
\hline & Business_Model_Canvas & \begin{tabular}{|l|}
161 \\
\end{tabular} & \begin{tabular}{|l|l|}
167 \\
\end{tabular} &, 329 & 2.217 & 0.063 &, 524 & \begin{tabular}{|c|}
.248 \\
\end{tabular} & \begin{tabular}{|l|}
133 \\
\end{tabular} & .064 & 1,000 &, 319 & \begin{tabular}{|l|l|}
181 \\
\end{tabular} & 674 \\
\hline & Criaçáo_do_Consumidor & 174 & \begin{tabular}{|l|}
.041 \\
\end{tabular} & .251 & 2115 & 379 & \begin{tabular}{|l|}
.216 \\
\end{tabular} & .662 & .247 & .351 &, 319 & 1,000 & .372 & .296 \\
\hline & $\begin{array}{l}\text { Construção_da_Organiza } \\
\text { çấo }\end{array}$ & 240 & 182 & .233 & .320 & .260 & \begin{tabular}{|l|l|}
165 \\
\end{tabular} & 15 & .429 & 2.281 & 1,181 & 372 & 1,000 & .248 \\
\hline & $\begin{array}{l}\text { Business_Model_Canvas } \\
{ }_{2} 2\end{array}$ & 218 & .174 & ,383 & .286 & .179 & .496 & \begin{tabular}{|c|}
2.263 \\
\end{tabular} & .052 & .123 & .674 & 2.298 & 2.248 & 1,000 \\
\hline
\end{tabular}

Fonte: Gerado no SPSS. 
Analisando a Matriz de Correlação, na tabela 5, verifica-se também que uma parte significativa dos resultados é inferior a 0,30 (correlações circuladas). Neste ponto da análise é preciso observar com atenção o padrão de correlação entre as variáveis, pois no caso de uma variável ser estatisticamente independente das demais pode ser cogitado a sua retirada (FIGUEIREDO FILHO; SILVA JÚNIOR, 2010). Porém, ainda segundo os autores, é possível aguardar o cálculo das comunalidades para então tomar a decisão de retirada ou não de variáveis, como foi desenvolvido neste estudo.

Para isto foi utilizado o teste de Esfericidade de Barlett (BTS) e o teste de Kaiser Meyer Olkinde (KMO) tendo em vista a determinação da existência ou não de correlação suficiente entre as variáveis tendo em vista a continuidade da Análise Fatorial (FIGUEIREDO FILHO; SILVA JÚNIOR, 2010). Os resultados obtidos são apresentados na Tabela 6 . Observa-se que 0 resultado do teste BTS é estatisticamente significante $(p<0,05)$ e o valor do KMO da amostra é de 0,689 , superior ao patamar crítico de 0,60 . Sendo assim é assim é possível concluir que a amostra é apropriada para o uso de Análise Fatorial (FIGUEIREDO FILHO; SILVA JÚNIOR, 2010).

Tabela 6: Teste de Esfericidade de Barlett e Kaiser Meyer Olkinde (KMO) em relação às respostas dos empreendedores de startups

\begin{tabular}{|ll|r|}
\hline Kaiser-Meyer-Olkin Measure of Sampling Adequacy. &, 689 \\
Bartlett's Test of & Approx. Chi-Square & 390,345 \\
Sphericity & df & 78 \\
& Sig. &, 000 \\
\hline
\end{tabular}

Fonte: Gerado no SPSS.

Segundo Figueiredo Filho e Silva Júnior (2010) o próximo passo na Análise Fatorial é a determinação de quais fatores irão permanecer. Na Tabela 7 são apresentados os autovalores. Como pode-se observar neste estudo foram obtidos quatro autovalores acima de 1, de forma que apenas os dois primeiros componentes (etapas de Imersão e Análise e Síntese) acumulados já explicam cerca de $45 \%$ da variabilidade entre os componentes e, com a acumulação dos quatro primeiros, é possível se alcançar um nível de explicação de cerca de $66 \%$ da variabilidade entre os componentes (etapas do Framework Cíclico). As informações ainda podem ser visualizadas por meio do gráfico Scree Plot (Gráfico 3). 
Tabela 7: Explicação da variância das etapas do Framework Cíclico em relação às respostas dos empreendedores de startups

\begin{tabular}{|c|c|c|c|c|c|c|}
\hline \multirow[b]{2}{*}{ Component } & \multicolumn{3}{|c|}{ Initial Eigenvalues } & \multicolumn{3}{|c|}{ Extraction Sums of Squared Loadings } \\
\hline & Total & $\%$ of Variance & Cumulative $\%$ & Total & $\%$ of Variance & Cumulative \% \\
\hline Imersão & 4,082 & 31,398 & 31,398 & 4,082 & 31,398 & 31,398 \\
\hline Análise_e_Síntese & 1,756 & 13,511 & 44,909 & 1,756 & 13,511 & 44,909 \\
\hline Descoberta_do_Consumidor & 1,559 & 11,995 & 56,904 & 1,559 & 11,995 & 56,904 \\
\hline Ideação & 1,182 & 9,090 & 65,994 & 1,182 & 9,090 & 65,994 \\
\hline Produto_Mínimo_Viável &, 875 & 6,729 & 72,723 & & & \\
\hline Canvas_do_Value_Propositio_Design & ,798 & 6,135 & 78,858 & & & \\
\hline Validação_do_Consumidor &, 614 & 4,721 & 83,579 & & & \\
\hline Implementação &, 559 & 4,299 & 87,878 & & & \\
\hline Prototipação &, 484 & 3,724 & 91,603 & & & \\
\hline Business_Model_Canvas &, 356 & 2,735 & 94,338 & & & \\
\hline Criação_do_Consumidor &, 313 & 2,410 & 96,748 & & & \\
\hline Construção_da_Organização &, 235 & 1,808 & 98,555 & & & \\
\hline Business_Model_Canvas_2 & ,188 & 1,445 & 100,000 & & & \\
\hline
\end{tabular}

Fonte: Adaptado de SPSS.

Gráfico 3: Scree Plot das etapas do Framework Cíclico para os empreendedores de startups

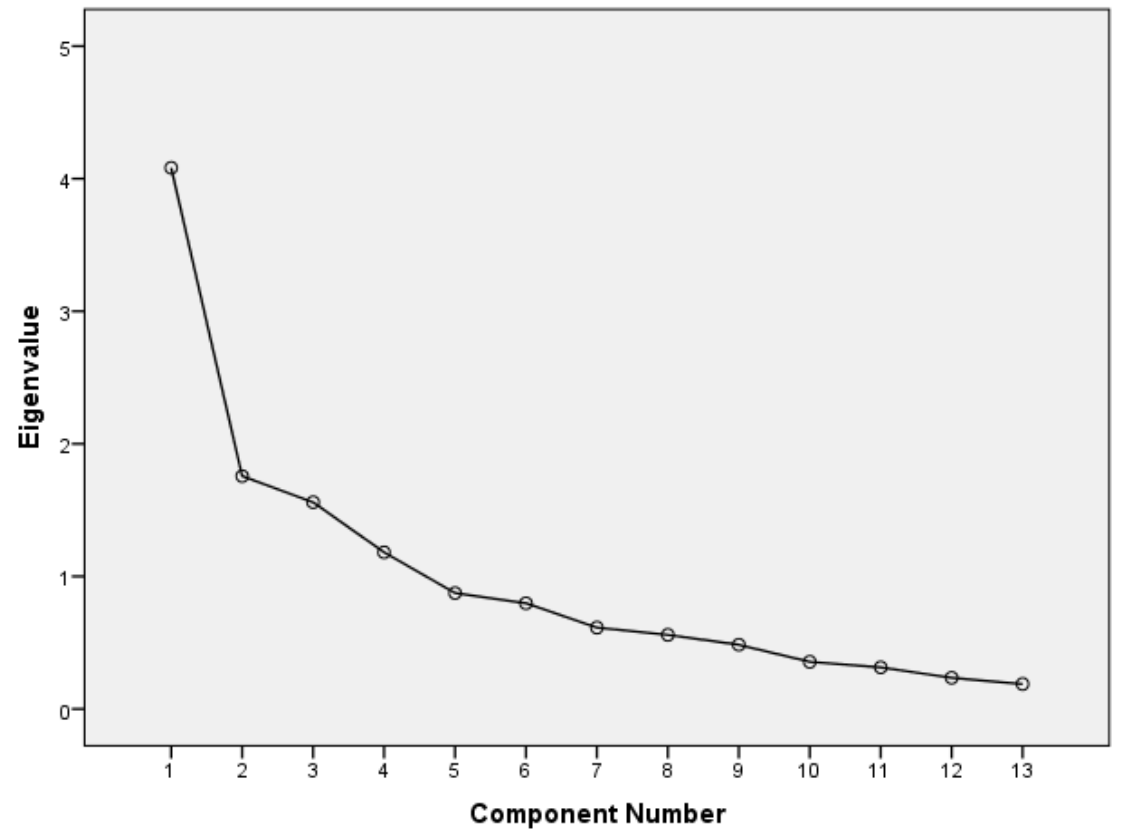

Fonte: Gerado no SPSS.

A Tabela 8 apresenta a Comunalidade das variáveis, ou seja, quanto o modelo está explicando sobre a variância de cada variável (FIGUEIREDO FILHO; SILVA JÚNIOR, 2010). Assim verifica-se uma explicação reduzida para a Ideação $(0,355)$ e Prototipação $(0,475)$; porém, de forma geral foi obtida uma boa explicação já que quanto maior o valor maior o seu poder de explicação. Para a comunalidade usualmente o valor mínimo aceitável é de 0,50 e, no caso de valores inferiores a este, cabe a exclusão da variável e refazer a Análise Fatorial (FIGUEIREDO FILHO; SILVA JÚNIOR, 2010). Assim a Análise Fatorial desta pesquisa foi refeita excluindo-se as variáveis "Ideação" e "Prototipação". 
Tabela 8: Comunalidade das etapas do Framework Cíclico em relação às respostas dos empreendedores de startups

\begin{tabular}{|l|c|r|}
\hline & \multicolumn{1}{|c|}{ Initial } & Extraction \\
\hline Imersão & 1,000 &, 766 \\
Análise_e_Síntese & 1,000 &, 793 \\
Descoberta_do_Consum & 1,000 &, 679 \\
idor & & \\
Ideação & 1,000 & $\mathbf{3 5 5}$ \\
Produto_Minimo_Viável & 1,000 &, 580 \\
Canvas_do_Value_Propo & 1,000 &, 590 \\
sition_Design & & \\
Validação_do_Consumid & 1,000 &, 747 \\
or & & \\
Implementação & 1,000 &, 756 \\
Prototipação & 1,000 & $\mathbf{4 7 5}$ \\
Business_Model_Canvas & 1,000 &, 800 \\
Criação_do_Consumidor & 1,000 &, 697 \\
Construção_da_Organiza & 1,000 &, 581 \\
çẵo & & \\
Business_Model_Canvas & 1,000 &, 760 \\
_2 & & \\
\hline
\end{tabular}

Fonte: Gerado no SPSS.

Uma nova Análise Fatorial, realizada com a retirada das variáveis "Ideação" e "Prototipação", apresentou como resultado uma Matriz de Correlação que não foi alterada em relação às variáveis que permaneceram; porém, desta vez o teste de Esfericidade de Barlett (BTS) e o teste de Kaiser Meyer Olkinde (KMO) foram alterados, obtendo-se KMO igual a 0,675 e BTS também estatisticamente significante $(p<0,05)$ (Tabela 9$)$, valores ainda acima dos patamares críticos e, desta forma, sendo a amostra considerada como apropriada para o uso de Análise Fatorial. Em relação à explicação da variância também verificou-se alteração, já que os dois primeiros componentes (Imersão, Análise e Síntese) acumulados que explicavam cerca de 45\%, passaram a explicar aproximadamente $49 \%$ e, quando acumulando os quatro componentes (Imersão, Análise e Síntese, Descoberta do Consumidor e Ideação) ocorreu um nível de explicação que se elevou de $66 \%$ para cerca de 73\% (Tabela 10). Também foi plotado um novo gráfico Scree Plot (Gráfico 4). Em relação a Comunalidade (Tabela 11) também verificou-se mudança em relação aos resultados obtidos e agora todas as variáveis apresentam comunalidade superior á 0,6. 
Tabela 9: Teste de Esfericidade de Barlett e Kaiser Meyer Olkinde (KMO) em relação às respostas dos empreendedores de startups, após a retirada de variáveis

\begin{tabular}{|c|c|c|}
\hline \multicolumn{2}{|c|}{ Kaiser-Meyer-Olkin Measure of Sampling Adequacy. } & ,675 \\
\hline \multirow{3}{*}{$\begin{array}{l}\text { Bartlett's Test of } \\
\text { Sphericity }\end{array}$} & Approx. Chi-Square & 341,475 \\
\hline & & 55 \\
\hline & Sig. & 000 \\
\hline
\end{tabular}

Fonte: Gerado no SPSS.

Tabela 10: Explicação da variância das etapas do Framework Cíclico em relação às respostas dos empreendedores de startups, após a retirada de variáveis

\begin{tabular}{|c|c|c|c|c|c|c|}
\hline \multirow[b]{2}{*}{ Component } & \multicolumn{3}{|c|}{ Initial Eigenvalues } & \multicolumn{3}{|c|}{ Extraction Sums of Squared Loadings } \\
\hline & Total & $\%$ of Variance & Cumulative \% & Total & $\%$ of Variance & Cumulative \% \\
\hline Imersão & 3,687 & 33,516 & 33,516 & 3,687 & 33,516 & 33,516 \\
\hline Análise_e_Síntese & 1,657 & 15,060 & 48,577 & 1,657 & 15,060 & 48,577 \\
\hline $\begin{array}{l}\text { Descoberta_do_Consumidor } \\
\text { Jdeacão }\end{array}$ & 1,476 & 13,419 & 61,995 & 1,476 & 13,419 & 61,995 \\
\hline Produto_Mínimo_Viável & 1,165 & 10,592 & 72,587 & 1,165 & 10,592 & 72,587 \\
\hline Canvas_do_Value_Propositio_Design &, 718 & 6,528 & 79,115 & & & \\
\hline Validação_do_Consumidor & 689 & 6,266 & 85,381 & & & \\
\hline Implementação &, 484 & 4,403 & 89,783 & & & \\
\hline Prototipação & 358 & 3,254 & 93,037 & & & \\
\hline Business_Model_Canvas & , 000 & 2867 & 95.904 & & & \\
\hline Criação_do_Consumidor & ,510 & & & & & \\
\hline Construção_da_Organização &, 237 & 2,157 & 98,061 & & & \\
\hline Business_Model_Canvas_2 &, 213 & 1,939 & 100,000 & & & \\
\hline
\end{tabular}

Fonte: Adaptado de SPSS.

Gráfico 4: Scree Plot das etapas do Framework Cíclico para os empreendedores de startups, após a retiradas de variáveis

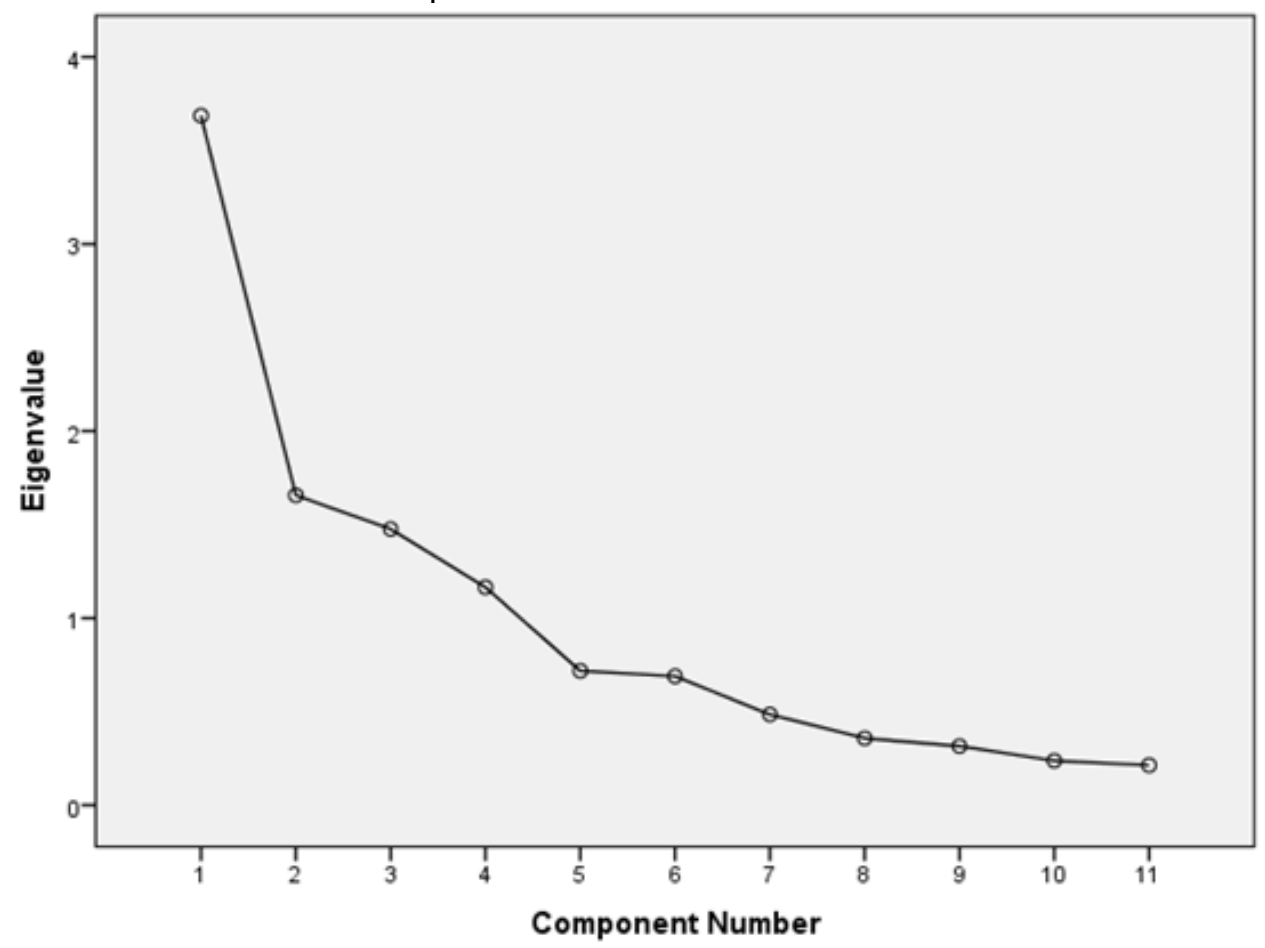

Fonte: Gerado no SPSS. 
Tabela 11: Comunalidade das etapas do Framework Cíclico em relação às respostas dos empreendedores de startups, após a retirada de variáveis

\begin{tabular}{|c|c|c|}
\hline & Initial & Extraction \\
\hline Imersão & 1,000 & ,807 \\
\hline Análise_e_Síntese & 1,000 &, 803 \\
\hline $\begin{array}{l}\text { Descoberta_do_Consum } \\
\text { idor }\end{array}$ & 1,000 & 690 \\
\hline Produto_Mínimo_Viável & 1,000 &, 587 \\
\hline $\begin{array}{l}\text { Canvas_do_Value_Propo } \\
\text { sition_Design }\end{array}$ & 1,000 &, 596 \\
\hline $\begin{array}{l}\text { Validação_do_Consumid } \\
\text { or }\end{array}$ & 1,000 & ,784 \\
\hline Implementação & 1,000 & ,783 \\
\hline Business_Model_Canvas & 1,000 & ,791 \\
\hline Criação_do_Consumidor & 1,000 &, 733 \\
\hline $\begin{array}{l}\text { Construção_da_Organiza } \\
\text { çäo }\end{array}$ & 1,000 & ,650 \\
\hline $\begin{array}{l}\text { Business_Model_Canvas } \\
\text { _2 }\end{array}$ & 1,000 &, 759 \\
\hline
\end{tabular}

Fonte: Gerado no SPSS.

A Tabela 12 apresenta os componentes sem a rotação fatorial, onde se verifica que grande parte das etapas do Framework Cíclico são justificadas pelos dois primeiros componentes, tendo as etapas ligadas ao componente em que seus valores constam como maiores na coluna. Neste ponto da análise Figueiredo Filho e Silva Júnior (2010) indicam que deve-se analisar a carga fatorial de cada variável e identificar as variáveis com cargas fatoriais elevadas (superior à 0,40) em mais de um componente. Estes itens estão circuladas na Tabela 12. Ainda segundo os autores, a análise dos componentes ocorre para que não se tenha indeterminação sobre a relação entre variáveis e fatores. 
Tabela 12: Matriz Componente das etapas do Framework Cíclico em relação às respostas dos empreendedores de startups

\begin{tabular}{|c|c|c|c|c|}
\hline & \multicolumn{4}{|c|}{ Component } \\
\hline & 1 & 2 & 3 & 4 \\
\hline $\begin{array}{l}\text { Descoberta_do_Consum } \\
\text { idor }\end{array}$ & .687 &,- 424 & & \\
\hline $\begin{array}{l}\text { Business_Model_Canvas } \\
{ }_{2}\end{array}$ & ,658 & &,- 532 & \\
\hline Criação_do_Consumidor & .633 & .428 &, 340 & \\
\hline $\begin{array}{l}\text { Validação_do_Consumid } \\
\text { or }\end{array}$ & .625 & 311 & 410 &,- 358 \\
\hline Business_Model_Canvas &, 621 & &,- 585 & \\
\hline Produto_Minimo_Viável & .544 & & 4,416 &,- 342 \\
\hline $\begin{array}{l}\text { Canvas_do_Value_Propo } \\
\text { sition_Design }\end{array}$ & .541 & &,- 494 & \\
\hline Análise_e_Síntese &, 524 &,- 693 & & \\
\hline Imersão & 607 &,- 649 & & \\
\hline Implementação &, 325 &, 354 & &, 688 \\
\hline $\begin{array}{l}\text { Construção_da_Organiza } \\
\text { ção }\end{array}$ & .515 & & & .543 \\
\hline
\end{tabular}

Fonte: Gerado no SPSS.

Na Tabela 13 realizou-se a rotação obtendo-se um melhor ordenamento e distribuição dos fatores; por este motivo não será necessária nova retirada de fatores e nova rotação.

Tabela 13: Matriz Componente com rotação das etapas do Framework Cíclico em relação às respostas dos empreendedores de startups

\begin{tabular}{|c|c|c|c|c|}
\hline & \multicolumn{4}{|c|}{ Component } \\
\hline & 1 & 2 & 3 & 4 \\
\hline Análise_e_Síntese & 883 & & & \\
\hline Imersão &, 882 & & & \\
\hline $\begin{array}{l}\text { Descoberta_do_Consum } \\
\text { idor }\end{array}$ &, 699 & & ,368 & \\
\hline Business_Model_Canvas & &, 876 & & \\
\hline $\begin{array}{l}\text { Business_Model_Canvas } \\
{ }_{-} 2\end{array}$ & & 837 & & \\
\hline $\begin{array}{l}\text { Canvas_do_Value_Propo } \\
\text { sition_Design }\end{array}$ & &, 750 & & \\
\hline $\begin{array}{l}\text { Validação_do_Consumid } \\
\text { or }\end{array}$ & & &, 865 & \\
\hline Criação_do_Consumidor & & &, 774 & \\
\hline Produto_Mínimo_Viável & & &, 713 & \\
\hline Implementação & & & & ,878 \\
\hline $\begin{array}{l}\text { Construção_da_Organiza } \\
\text { ção }\end{array}$ & & & &, 744 \\
\hline
\end{tabular}

Fonte: Gerado no SPSS.

A Tabela 14 apresenta a Matriz Ortogonal utilizada para a rotação dos fatores e o Gráfico 5 apresenta a base de dados analisada considerando seus fatores posicionados conforme sua carga fatorial em relação aos componentes. 
Tabela 14: Matriz Ortogonal das etapas do Framework Cíclico em relação às respostas dos empreendedores de startups

\begin{tabular}{|l|r|r|r|r|}
\hline Component & \multicolumn{1}{|c|}{1} & \multicolumn{1}{|c|}{2} & \multicolumn{1}{c|}{3} & \multicolumn{1}{l|}{4} \\
\hline 1 &, 526 &, 565 &, 559 &, 302 \\
2 &,- 842 &, 306 &, 314 &, 314 \\
3 &, 048 &,- 766 &, 556 &, 320 \\
4 &, 048 &,- 026 &,- 530 &, 841 \\
\hline
\end{tabular}

Gráfico 5: Base de dados posicionando os fatores conforme a carga fatorial nos componentes das etapas do Framework Cíclico para os empreendedores de startups

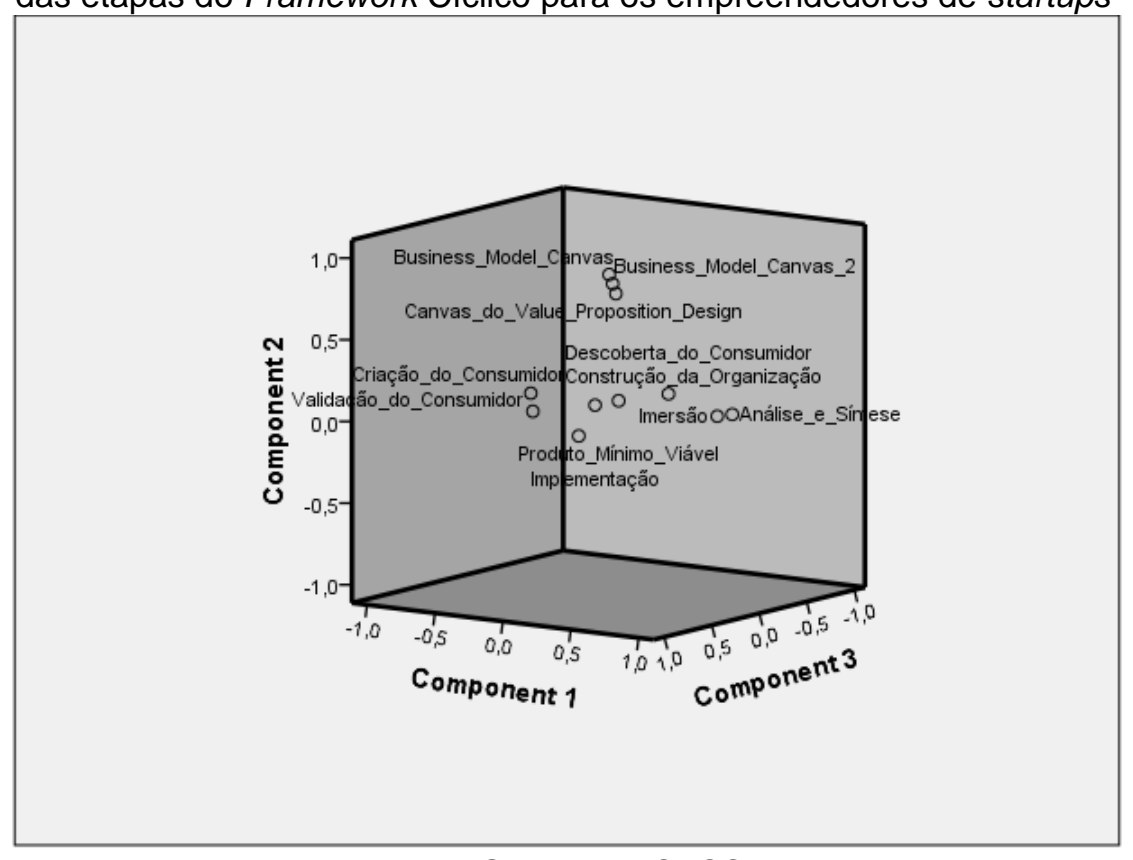

Fonte: Gerado no SPSS.

As conclusões formuladas com base nos resultados obtidos será apresentada no item 5 deste documento. Num segundo momento foi realizada a Análise Qualitativa sobre a recomendação ou não em relação à utilização das fases e etapas proposta pelo Framework Cíclico por parte dos respondentes. Assim todas as respostas foram lidas e buscou-se padrões e informações interessantes para serem agregadas a este estudo, permitindo assim maior riqueza na estruturação e validação do Framework Cíclico.

\subsubsection{Análise Qualitativa dos Resultados Obtidos}

Para a Análise Qualitativa dos questionários foram analisadas todas as observações dos respondentes; vale lembrar que todas as questões fechadas propostas neste estudo apresentavam questões complementares abertas, para que os respondentes pudessem incluir pontos que consideram como 
relevantes. A seguir são apresentados resumos sobre os principais resultados obtidos com as questões abertas e os pontos mais relevantes levantados pelos respondentes.

Imersão: Busca o entendimento do ambiente, do mercado e dos segmentos de clientes de interesse; usualmente inclui ampla pesquisa sobre estes tópicos, aplicando técnicas como benchmarks, levantamento da voz do cliente, pesquisas bibliográficas, entre outros.

Pontos relevantes em relação a etapa de Imersão:

Imersão - algumas vezes as startups não passaram pela etapa, pois esta já proveio de ideia formada e estruturada numa grande organização, mas empreendedores que não a desenvolveram sentem falta. Nesta etapa vale incluir a análise dos problemas a serem solucionados e se estes efetivamente incomodam os consumidores potenciais, sendo preciso falar com os consumidores e entender as suas necessidades, entendendo o mercado e investigando se as ideias têm realmente mercado e relevância, atuando como visão geral sobre a viabilidade do negócio. A etapa não pode ser muito extensa para que não se corra o risco de ficar apenas no papel, porém demanda tempo pois é preciso desenvolver uma pesquisa ampla, buscando por detalhes, viabilizando contato real com clientes potenciais para entender sua rotina e também o que este valoriza; se esta etapa não for desenvolvida com atenção pode comprometer toda a evolução da startup, pois é a base de sua construção, é neste momento que as metas já podem começar a ser desenhadas. Momento fundamental para poupar tempo e dinheiro futuramente, pois pode antecipar falhas e gerar economias, porém para isso é preciso fazer as perguntas certas aos clientes para que assim se obtenha as respostas certas; logo, se o empreendedor dominar o assunto explorado terá maior facilidade em obter as melhores respostas. É uma fase de grande aprendizado obtido com os feedbacks dos clientes.

Análise e Síntese: Consolida as informações obtidas na Imersão e busca estabelecer padrões e conexões entre estas utilizando de técnicas como personas, mapa de empatia e jornada do usuário. 


\section{Pontos relevantes em relação a etapa de Análise e Síntese:}

Análise e Síntese - neste momento as análises precisam ser rápidas, simples e flexíveis, e para isso vale o uso de bom senso, buscando uma visão mais clara sobre os pontos mais relevantes e o entendimento a partir de pesquisas já realizadas, devendo se ter cuidado para que não ocorra excesso e consequente improdutividade. Nesta fase é preciso ser imparcial, sem se deter ou apegar às opiniões pessoais e buscando ser realista, de forma a identificar como o negócio poderá influenciar a vida das pessoas. O desafio maior é definir o perfil claro dos consumidores potenciais para o desenho das ideias e da estrutura do negócio, estabelecendo a correspondência entre o conceito do negócio e o público alvo de forma a desenvolver o que irá satisfazer e eventualmente encantar o cliente em sua rotina. Aqui também deve-se construir a proposta de valor e o discurso de venda, além de verificar a viabilidade técnica e econômica do empreendimento, adequando a proposta de valor e o preço que será cobrado, eventualmente também utilizando análise estatística. Quem não desenvolveu esta etapa pode sentir falta dos seus resultados durante a estruturação da startup. Ao final da etapa pode ocorrer mudança de estratégia, pois este é momento de se esclarecerem as dúvidas e de se verificar se a solução está alinhada com os consumidores a partir dos levantamentos realizados.

Descoberta do Consumidor: Consiste em transformar a visão estabelecida para a solução na etapa de "Análise e Síntese" numa série de hipóteses que serão testadas para verificação das reações dos consumidores e validação do seu real interesse.

Pontos relevantes em relação a etapa de Descoberta do Consumidor:

Descoberta do Consumidor - é o momento de validar hipóteses e conceitos com os clientes potenciais, em que o desafio principal é identificar o usuário correto. Nesta etapa deve-se gerar empatia e aproximação com o cliente tendo em vista o aprimoramento das ações da empresa. Neste contexto os testes dão maior certeza em relação às escolhas da organização, uma vez que os consumidores devem ser expostos às suas ofertas efetivas. Caso esta 
etapa seja mal desenvolvida pode levar o empreendedor à falência. Aqui devese buscar por reações reais e não simuladas do cliente e também verificar se e quanto ele está disposto a pagar. É uma fase que deve ser desenvolvida de maneira dinâmica e intuitiva, com base nos insights e feedbacks dos clientes, sendo considerada uma etapa essencial para o seu conhecimento pleno, com a identificação de nichos e de demandas de mercado, de quem vai comprar e como vai comprar. Empreendedores que não desenvolveram esta etapa sentiram sua falta e acreditam que seja de extrema importância.

Ideação: Busca a geração e refinamento das primeiras ideias, permitindo o teste das ideias aplicando técnicas como brainstorming, cardápio de ideias e matriz de posicionamento.

Pontos relevantes em relação a etapa de Ideação:

Ideação - é preciso usar de criatividade, bom senso, ter foco e saber ouvir os demais stakeholders envolvidos, sempre com muita organização. Neste momento ocorre a formatação da startup, quando a oferta a ser proposta precisa ser avaliada considerando uma perspectiva ampla, buscando o aprimoramento dos conhecimentos obtidos, buscando-se trabalhar com o que efetivamente têm valor para os consumidores. Nesta etapa deve-se considerar tudo o que possa dar errado, sendo algo muito mais prático do que efetivamente documentado; é o momento de pensar e iniciar o caminho que será seguido pela startup, buscando-se estabelecer as novas hipóteses que futuramente serão testadas. É uma etapa fundamental para se criar algo único e que seja difícil de ser copiado, de forma a se realizar todos os testes para preparar o que será ofertado para o mercado, aprimorando e fortalecendo o projeto, explorando as suas possibilidades, pois uma vez que a ideia esteja bem estruturada é mais fácil apresentá-la ao cliente; porém é preciso cuidado para não se buscar demais a perfeição e perder muito tempo. Empreendedores que não empregaram esta etapa sentiram sua falta.

Produto Mínimo Viável: Construção de protótipo de baixa ou alta fidelidade e que incorpora as principais funções definidas como relevantes pela startup, de forma a permitir um primeiro teste das hipóteses elaboradas pelo empreendedor até o momento. 


\section{Pontos relevantes em relação a etapa de Produto Mínimo Viável:}

Produto Mínimo Viável - busca colocar a "mão na massa" efetivamente, quando se sai da teoria, permitindo o favorecimento da venda pela experimentação do produto. Uma boa forma de economizar futuramente é validar o que será ofertado aos consumidores, porém deve se oferecer apenas o mínimo de forma a permitir sua validação e validar também a proposta de valor. Neste momento torna-se imprescindível para o projeto aprender a partir dos testes realizados e, se for o caso, pivotar com os pressupostos anteriores, permitindo que a oferta seja colocada logo no mercado e obtenha feedback dos consumidores, evidenciando suas necessidades. É preciso ter a consciência de que talvez seja preciso alterar o seu produto, retirando o que for irrelevante e mantendo o que for relevante, de forma a absorver os insights obtidos. É ainda uma forma de testar o mercado, de se determinar os custos envolvidos, podendo inclusive evidenciar novos usos para o produto e evitar problemas futuros, de forma a reduzir o risco de enfrentar um longo tempo de desenvolvimento de algo que não é desejado.

\section{Canvas do Value Proposition Design: Busca identificar as principais necessidades, sentimentos e desejos do consumidor e alinhar a criação de valor para o mesmo por meio da identificação das características, benefícios, e experiências que serão viabilizadas pelo produto e/ou serviço. \\ Pontos relevantes em relação a etapa de Canvas do Value Proposition Design:}

Canvas do Value Proposition Design - auxilia na análise das "dores do cliente" em relação às propostas contidas no Produto Mínimo Viável. Quando bem elaborado esta ferramenta evidencia claramente a necessidade do cliente e seu alinhamento com a proposta do produto da organização, podendo auxiliar no evidenciamento de lacunas que ainda possam existir. Contribui na organização das ideias e na representação gráfica do projeto, auxiliando no desenho da proposta de valor e na comunicação dos principais pontos do modelo de negócios, trabalhando com suas articulações e permitindo pensar especificamente no cliente. Auxilia no desenho de como o negócio deve gerar, 
entregar e sustentar valor para os segmentos de clientes. Alguns empreendedores desconhecem a abordagem.

Pontos relevantes em relação a etapa de Canvas do Value

Proposition Design em conjunto com o Mínimo Produto Viável:

Canvas do Value Proposition Design em conjunto com o Mínimo Produto Viável - são ambos complementares, dinâmicos e vivos, auxiliando na validação da proposta de valor e assim minimizando os esforços futuros para entrega de valor ao cliente, com a revisão dos pontos e permitindo alinhamento e foco. Empreendedores que não trabalharam com a junção de ambas as abordagens acreditam que esta seja uma proposta interessante.

Validação do Consumidor: Busca aprender mais sobre o público de interesse e para isto apresenta o Produto Mínimo Viável e realiza testes de aceitação junto aos consumidores potenciais.

Pontos relevantes em relação a etapa de Validação do Consumidor:

Validação do Consumidor - ocorre quando os feedbacks dos clientes são obtidos em tempo real, sendo o momento de avaliar se o produto está atendendo às reais necessidades dos clientes, minimizando os riscos de eventuais investimentos em aumento de escala, auxiliando até mesmo com argumentos de vendas para clientes futuros. Auxilia como um indicador de mercado e como o desenvolvimento de algo desejado pelos clientes; porém, é preciso estar aberto às mudanças a partir da identificação de erros no modelo de negócios. É essencial para orientar ajustes e melhorias, mas para isso é preciso atenção a tudo que for apresentado.

Implementação: Tem como foco viabilizar o estabelecimento das operações da startup, incluindo a finalização dos seus produtos e serviços e início das transações com os segmentos de clientes de interesse.

Pontos relevantes em relação a etapa de Implementação:

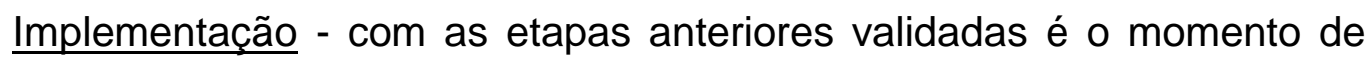
chegar ao produto final, sendo uma etapa natural e uma das mais importantes 
do processo, consistindo na maturação operacional tendo em vista ganho de escala.

Prototipação: Com base nos resultados obtidos com os testes do Produto Mínimo Viável esta etapa tem por objetivo viabilizar uma primeira versão comercial do produto e/ou serviço que será oferecido ao mercado.

Pontos relevantes em relação a etapa de Prototipação:

Prototipação - auxilia na validação, gerando economia no desenvolvimento do produto; neste momento a "cara do projeto" é definida e a sua usabilidade fica evidente, dando vida ao projeto. Permite que o produto seja validado sem chegar ao desenvolvimento final, funcionando como um teste de campo funcional, testando a aceitação do mercado, eliminando possíveis erros futuros e ampliando as ideias, ainda auxiliando na identificação de novas oportunidades.

Business Model Canvas: Plano de negócios dinâmico que envolve de forma macro as etapas de: Segmentos de Consumo, Proposição de Valor, Canais, Relação com o Consumidor, Fontes de Receitas, Recursos Chave, Atividades Chave, Parcerias Chave e Estrutura de Custos.

Pontos relevantes em relação a etapa de Business Model Canvas:

Business Model Canvas - traz planejamento e segurança para a operação, mostrando onde serão os investimentos do negócio e seu potencial, pois é a organização dos principais pontos relacionados com a startup, auxiliando muito no seu planejamento estratégico. Sofre mudanças no decorrer do processo, faz pensar sobre o modelo de negócios, deve estar bem visível ao empreendedor, atuando como meta. A parte de custos e receitas precisa ser mais detalhada pois este é o momento de se errar menos ou até mesmo errar mais rápido.

Pontos relevantes em relação a etapa de Business Model Canvas em conjunto com a Prototipação: 
Business Model Canvas em conjunto com a Prototipação - muito importante para a validação das hipóteses, é uma forma de já ir trabalhando nos feedbacks conforme estes são recebidos. União da ideia com a sua materialização, permitindo o entendimento rápido entre o modelo de negócio e a sua viabilidade, permitindo que se seja mais assertivo.

Criação do Consumidor: Tem como foco realizar as primeiras vendas efetivas do produto e/ou serviço, confirmando se a proposta de valor efetivamente resolve a questão do consumidor. Pontos relevantes em relação a etapa de Criação do Consumidor:

Criação do Consumidor - é a junção de "dor do consumidor" com a solução, sendo a comprovação final do valor do produto, auxiliando na criação da solução adequada ao consumidor. Uma ideia apenas vira um produto quando é efetivamente comprada, auxiliando até mesmo na estruturação do preço, sendo a porta de entrada do mercado. Empreendedores que não utilizaram esta etapa sentiram sua falta.

Construção da Organização: Busca estabelecer todos os demais aspectos para operacionalização da startup, incluindo a aquisição dos recursos principais, desenvolvimento de parcerias $e$ estabelecimento das atividades produtivas.

Pontos relevantes em relação a etapa de Construção da Organização:

Construção da Organização - é o momento de desenhar a organização, verificar as parcerias potenciais, construir o time de trabalho da organização, onde a estrutura física da empresa é efetivamente implementada, permitindo a elaboração da missão, da visão e dos valores, alinhando o "onde" e o "como" chegar. Auxilia a desenhar os pontos positivos e negativos da empresa. Empreendedores que não a utilizaram sentiram sua falta.

Pontos relevantes em relação a etapa de Business Model Canvas em conjunto com a Construção da Organização: 
Business Model Canvas em conjunto com a Construção da Organização - considerado uma sinergia completa, onde é preciso estabelecer o desenho da organização para não se atuar "às escuras", unindo as pontas do círculo do projeto.

Após todas as análises das respostas dos empreendedores foi possível caminhar em direção à finalização desta pesquisa com a construção da quarta e última versão do Framework Cíclico, elaborado para auxiliar as startups na definição e refinamento de conceitos, além da construção inicial de sua operação. 


\section{RESULTADOS FINAIS DA PESQUISA}

Com base nas diferentes iniciativas de levantamento de dados realizadas e nos resultados obtidos com a aplicação de diferentes métodos de análise foi possível obter conclusões capazes de responder às indagações iniciais desta pesquisa. A Revisão de Literatura buscou identificar se "existem fases e etapas indicadas pela literatura para a geração e refinamento de conceitos e para a estruturação da operação inicial de novas startups? Se sim, quais são?"; como resposta ocorreu a elaboração da primeira versão do Framework Cíclico, contando com as fases e etapas indicadas pela literatura para a geração e refinamento de conceitos e a estruturação da operação inicial de novas startups.

O segundo método utilizado foi o "Painel de Especialistas", que orientou as mudanças no desenvolvimento de cada uma das etapas do Framework Cíclico, viabilizando a substituição do Business Model Canvas pelo Canvas do Value Proposition Design tendo em vista seu uso em conjunto com o Mínimo Produto Viável. Neste momento, com base na opinião dos especialistas, buscou-se responder às seguintes perguntas:

- "Considerando a opinião de especialistas em startups, quais das etapas propostas pelo Framework Cíclico são efetivamente relevantes na constituição de uma startup de sucesso? E quais são consideradas menos relevantes? - A maioria significante dos especialistas classificou todas as etapas como relevantes.

- "A maioria destas etapas são recomendadas por estes especialistas para a constituição de novas startups de sucesso?" - Sim, a maioria das etapas foram recomendadas pelos especialistas

Evoluindo com a pesquisa foi aplicada uma survey junto à empreendedores de startups em processo de aceleração ou aceleradas por aceleradoras brasileiras. Verificou-se que o perfil dos empreendedores é de homens, com idade média de 34 anos e graduados, mas com parcela significativa de pós-graduados e mestres. Estes empreendedores apresentam média de 7 anos de atuação profissional; já a média do número de startups em que atuaram é 2, mas parte significativa está atuando em sua primeira startup. Em relação à startup atual o tempo médio de atuação é de 4 anos, porém a 
maioria atua entre 1 e 2 anos; a média de anos de existência das startups é de 4 anos, porém a maioria existe a cerca de 2 ou 3 anos. Assim foi respondida a questão "qual o perfil dos empreendedores das startups de sucesso abordados nesta pesquisa?".

Considerando quanto os empreendedores das startups efetivamente fizeram uso das etapas propostas pelo Framework Cíclico, num comparativo com o total de respondentes verificou-se uma frequência mínima de 54\%, conforme apresentado na Tabela 2. Assim, as etapas propostas foram efetivamente utilizadas por pelo menos metade dos empreendedores. Sobre sua recomendação, ao menos $87 \%$ das etapas foram recomendadas, evidenciando que embora às vezes o empreendedor não tenha desenvolvido a etapa ele ainda assim recomenda sua realização. Vale ressaltar que em ambas questões a etapa que foi menos utilizada (54\%) e menos recomendada (87\%) foi a do Canvas do Value Proposition Design, fato que pode ser justificado pois esta é uma técnica relativamente nova.

Desta maneira o estudo trouxe respostas às seguintes indagações:

- "A maioria das etapas são recomendadas por estes empreendedores para a constituição de novas startups de sucesso?" - Sim, todas as etapas foram recomendadas por pelo menos $87 \%$ dos empreendedores das startups estudadas.

- "Os empreendedores das startups de sucesso efetivamente utilizaram as etapas identificadas anteriormente para buscar 0 sucesso das suas startups?" - Sim, ao menos $54 \%$ dos empreendedores das startups utilizaram as etapas propostas.

Considerando a análise descritiva das etapas proposta no Framework Cíclico foram verificadas médias elevadas, demonstrando que estas etapas são muito utilizadas pelos empreendedores. Não foi verificada nenhuma média inferior à 3,18, que corresponde à opção "em cerca de metade dos projetos", de forma que ao menos em metade dos projetos todas as etapas propostas foram utilizadas. Considerando o desvio padrão da mesma amostra, o mais elevado foi o Business Model Canvas $(1,443$ e 1,411) e o Canvas do Value Proposition Design (1,344), demonstrando menor alinhamento entre os respondentes em relação à realização desta fase; este desvio padrão é menor 
para a etapa de Imersão $(1,019)$, evidenciando maior alinhamento quanto ao seu uso. De forma geral este desvio padrão não muito elevado evidencia que o uso das etapas propostas é significativo.

Desta maneira foi possível responder mais uma das perguntas desta pesquisa: "considerando a opinião de empreendedores de startups, quais das etapas propostas pelo Framework Cíclico são efetivamente relevantes na constituição de uma startup de sucesso? E quais são consideradas menos relevantes?" - sim, as etapas foram utilizadas em ao menos metade dos projetos dos empreendedores das startups analisadas nesta pesquisa, exceto as etapas de Business Model Canvas e Canvas do Value Proposition Design, fato que se justifica já que estas são metodologias ainda novas e que muitas vezes ainda geram controvérsias quanto ao seu uso ou não. Estas etapas são utilizadas como auxiliares nas etapas de Mínimo Produto Viável ( Value Proposition Design) e Prototipação e Construção da Organização (no caso do Business Model Canvas), comprovando que o Framework possui etapas relevantes.

A metodologia de Análise Fatorial foi responsável para responder à indagação "qual a distribuição ideal de etapas para cada fase do Framework Cíclico?". Os resultados obtidos evidenciaram o agrupamento dos seguintes fatores:

- Fator 1 - explica cerca de $37 \%$ da variância total, composto por 3 variáveis positivamente relacionadas; caracterizado pelas variáveis Análise e Síntese, Imersão e Descoberta do Consumidor. Todas as variáveis representam etapas que compõe a proposta para a fase de Geração de Ideias, assim a proposta do Framework Cíclico está alinhada à primeira fase.

- Fator 2 - representa cerca de 15,5\% da variância total, fator que representa a fase de Conversão, incluindo as variáveis Descoberta do Consumidor, Validação do Consumidor, Produto Mínimo Viável e Criação do Consumidor. Neste ponto faltou a etapa de Ideação, retirada por ter baixo valor de Comunalidade e assim não ser justificada pela sua variância. Desta maneira verifica-se o alinhamento com as etapas de Validação do Consumidor e Produto Mínimo Viável. Por sua vez a Descoberta do Consumidor, que na 
proposta estava na fase de Geração de Ideias e não na Conversão, porém como seu valor foi baixo, pode-se continuar com a ideia inicial proposta. Já a Criação do Consumidor na proposta pertencia à fase de Difusão e não à fase de Conversão como a Análise Fatorial indicou; este ponto será melhor avaliado a seguir.

- Fator 3 - representa aproximadamente 13\% da variância total, onde tem-se um fator que determina as etapas auxiliares Canvas do Value Proposition Design e Business Model Canvas e as etapas principais Mínimo Produto Viável, Prototipação e Construção da Organização. Desta forma o fator e a proposta do Framework Cíclico estão alinhados.

- Fator 4 - têm cerca de $11 \%$ da representatividade da variância total, fator que representa a fase de Difusão e é composto por Implementação, Criação do Consumidor e Construção da Organização. Na proposta tem-se a etapa de Prototipação fazendo parte do fator, mas o mesmo precisou ser retirado por apresentar baixo valor de Comunalidade e assim não ser justificada pela sua variância. Para a Criação do Consumidor ocorreu uma representatividade baixa, menor do que no fator 2 , ponto também a ser discutido. Para Implementação e Construção da Organização ocorreu alinhamento com o Framework proposto por esta pesquisa.

Assim as etapas estão alinhadas entre a proposta do Framework Cíclico e a Análise Fatorial exceto a de Criação do Consumidor, que consiste em construir mercado consumidor para a organização e foi indicada como pertencente a fase de Conversão e não de Difusão como o Framework propõe. Após reflexão optou-se por seguir a recomendação da Análise Fatorial, mostrando-se relevante a Criação de Consumidor ocorrer antes da efetiva Implementação da organização.

Ocorreu também que a Comunalidade para as etapas de Ideação e Prototipação foram reduzidas, de forma que a variância destas variáveis apresentam explicação reduzida, mas mesmo assim optou-se por mantê-las uma vez que são consideradas como essenciais para o Framework e que não estavam muito abaixo do valor desejado. Desta maneira, consolidando as 
considerações da Análise Fatorial tornou-se possível alcançar a quarta e última versão do Framework Cíclico elaborado nesta pesquisa, conforme Figura 19. 
Figura 19: Quarta e final versão do Framework Cíclico

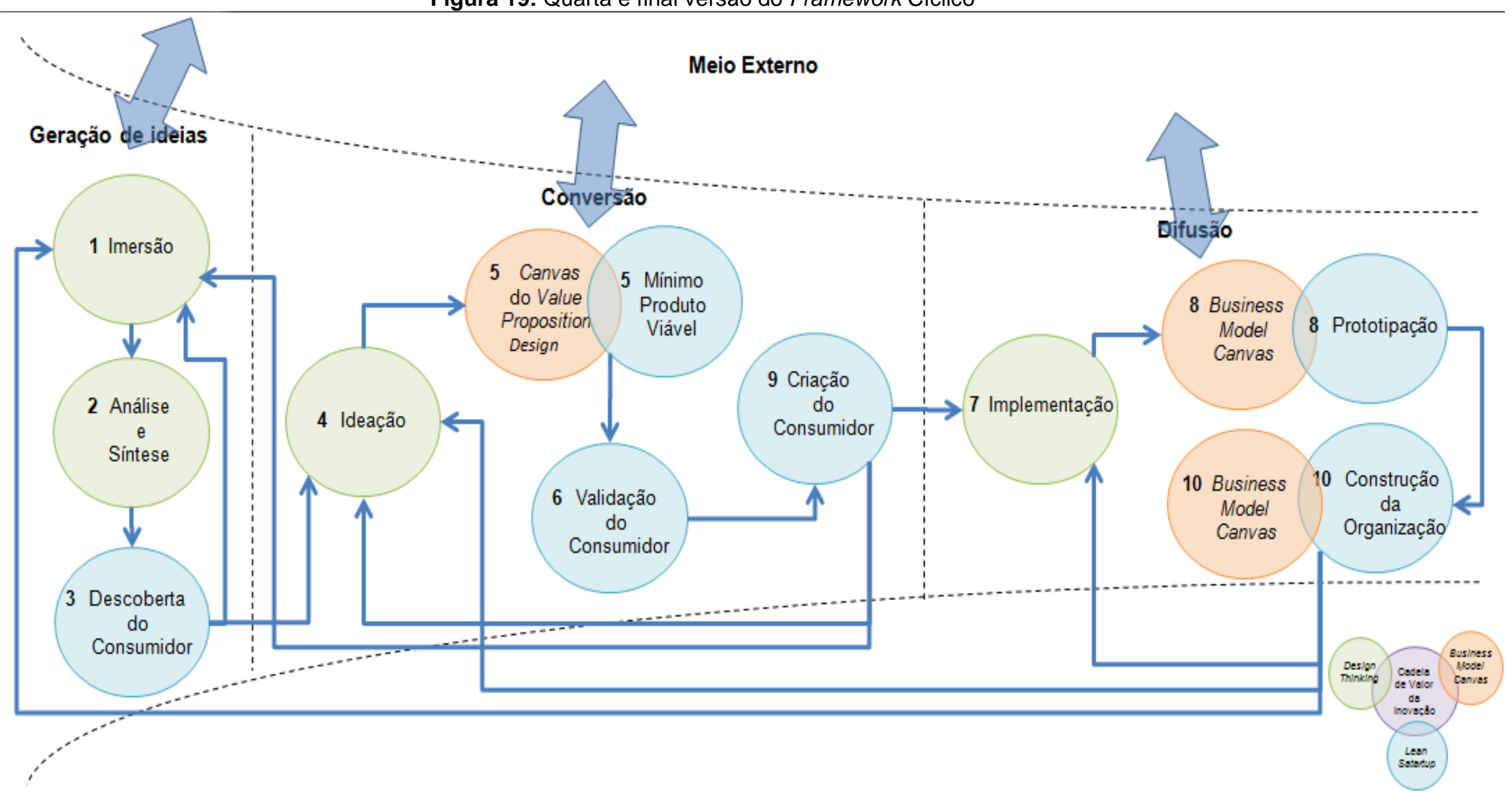

Fonte: Elaborado pela autora. 
Detalhando as suas fases e etapas numa versão final tem-se na fase de Geração de ideias as etapas de Imersão e Análise e Síntese do Design Thinking e de Descoberta do Consumidor do Lean Startup. Na etapa de Imersão ocorre um mergulho profundo para a geração das ideias, envolvendo entrevistas e observações no contexto de interesse do empreendedor tendo em vista a busca pelo entendimento sistêmico da situação. Neste momento cabe a análise dos problemas que serão solucionados e se estes problemas efetivamente incomodam os consumidores potenciais (são suas "dores"), sendo preciso falar com os consumidores e entender as suas reais necessidades, além de investigar se as ideias propostas têm realmente mercado e relevância, estabelecendo a visão geral sobre a viabilidade do negócio. A etapa não pode ser muito extensa para que não se corra o risco de ficar apenas no papel, mas demanda tempo, pois é preciso desenvolver uma pesquisa ampla, buscando por detalhes e por respostas para tudo que não se sabe, sendo necessário contato real com os clientes potenciais para compreender sua rotina e também o que valorizam. Se esta etapa não for desenvolvida com atenção pode comprometer a evolução da startup pois é a base da sua construção, é o momento que as metas começam a serem desenhadas. A etapa é fundamental para poupar tempo e dinheiro futuramente, pois pode antecipar falhas que futuras; porém, para isso é preciso fazer a pergunta certa ao cliente certo. É uma etapa de aprendizado obtido com os feedbacks dos clientes.

A etapa de Análise e Síntese consiste na análise das situações encontradas por meio da Imersão, sendo o momento de consolidar o que foi descoberto buscando estabelecer padrões e conexões. Porém as análises precisam ser rápidas, simples e flexíveis e para isso vale ter uma visão clara sobre os pontos mais relevantes, obtido a partir das pesquisas já realizadas, devendo se ter cuidado para que não ocorra excesso e consequente improdutividade. Para o sucesso desta etapa é preciso que o empreendedor seja imparcial, não se detendo ou se apegando à opiniões pessoais, estando aberto para conhecer como o seu negócio poderá influenciar a vida das pessoas; ao final desta etapa podem ocorrer mudanças na estratégia, pois este é momento de se esclarecer as dúvidas e de se verificar se a solução esta alinhada com os desejos e necessidades dos consumidores. Um grande 
desafio é definir o perfil claro dos consumidores potenciais para priorizar ideias e desenhar a estrutura do negócio, construindo uma correspondência entre o conceito do negócio e o público alvo para desenvolver o que irá satisfazê-lo em sua rotina. Nesta etapa também se constrói a proposta de valor e o discurso de venda, além de se verificar a viabilidade técnica e econômica do projeto, sintetizando e criando foco de atuação com a adequação da proposta de valor e o preço que será cobrado, o que pode ser auxiliado pelas informações coletadas e pelo uso de análises estatísticas.

Na etapa de Descoberta do Consumidor vale ressaltar a importância do próprio empreendedor ir a campo fazer entrevistas e entender os consumidores potenciais, tarefa que não deve ser terceirizada, sendo de suma importância para o sucesso da startup em processo de estruturação. Ainda neste momento é preciso que o empreendedor tenha flexibilidade já que não existe uma fórmula única para se saber quantas pessoas entrevistar, cabendo ao empreendedor identificar o momento em que a sua curva de aprendizagem passa a apresentar uma evolução mínima ou estagna, sendo este o momento de parar. É preciso ter cuidado para não se perder no tempo pelo número elevado de entrevistas, sendo necessário dinamismo. Este é o momento de se validar hipóteses e conceitos com os clientes potenciais, devendo-se buscar empatia e aproximação com o cliente para o aprimoramento das ações da empresa. Os consumidores devem ser expostos às ofertas da organização o quanto antes. Deve-se buscar por reações reais e não simuladas, e verificar se o cliente está efetivamente disposto a pagar pelo que se pretende ofertar. É uma etapa que deve ser desenvolvida de maneira dinâmica e intuitiva, com base nos insights e feedbacks dos clientes, buscando a identificação de nichos e demandas de mercado, sobre quem vai comprar e como vai comprar. Ao seu final é preciso ter a real ideia do problema que será resolvido, tendo cuidado para que a etapa não se torne exaustiva, garantindo o dinamismo necessário para o empreendedor, porém com atenção e zelo, pois se esta etapa for mal desenvolvida pode levar o empreendedor à falência.

Finalizando a fase de Geração de Ideias é esperado que se tenha um entendimento bastante completo da situação, conhecimento sobre o consumidor potencial, além de se ter gerado e analisado ideias com foco nestes consumidores. Caso não se esteja seguro ao final desta fase vale 
refazê-la, uma vez que é preciso ter segurança para seguir adiante, já que quanto mais se evolui no desenvolvimento da startup, mais difícil será desenvolver mudanças pois estas implicarão em grandes retrabalhos.

A etapa de Conversão é composta pela Ideação do Design Thinking, o Produto Mínimo Viável, a Validação e a Criação do Consumidor do Lean Startup e o Canvas do Value Proposition Design. A Ideação emprega a matriz de posicionamento, que contribui com o desenvolvimento e testes de ideias, sendo preciso contar com criatividade, bom senso, foco e saber ouvir. Neste momento ocorre a formatação da startup, e o que será ofertado deve ser avaliado numa perspectiva ampla, aprimorando o conhecimento existente, trabalhando com o que efetivamente têm valor para os consumidores. Deve-se pensar em tudo o que pode dar errado, sendo algo muito mais prático do que efetivamente documentado, é o momento de se pensar e de se trilhar o caminho que será seguido pela startup, devendo se criar as hipóteses que futuramente serão testadas. É uma etapa crucial para criar algo único, que seja difícil de ser copiado, tendo em vista a realização de todos os testes para preparar o que será ofertado para o mercado, aprimorando e fortalecendo o projeto, explorando as suas possibilidades, pois uma vez que a ideia está bem estruturada é mais fácil apresentá-la ao cliente. Deve-se ter cuidado para não buscar a perfeição e perder muito tempo. Uma sugestão interessante para 0 empreendedor neste momento é que atue na área de interesse afim de identificar seus gargalos e desmistificar a ideia de que ter o seu próprio negócio é "uma festa", possibilitando um mergulho no funcionamento do negócio e de sua Cadeia de Valor, permitindo inclusive uma avaliação sumária de retorno que pode ser obtido no setor. Quando não for possível este vivenciamento é preciso mergulhar no setor por meio das mídias sociais e de conversas com pessoas do setor.

Em relação ao Produto Mínimo Viável é preciso ter como foco desenvolver algo tangível, que possa ser testado, sendo de suma importância que antes de seu desenvolvimento seja compreendido o que pode ser considerado como "minimamente aceitável" para testes, não devendo-se confundir com a Prototipação, que consiste em algo mais elaborado, uma replica do que se objetiva desenvolver. No Produto Mínimo Viável ocorre apenas um primeiro esboço, a elaboração de um rascunho. O objetivo maior é 
estabelecer um fluxo de aprendizagem baseado na experimentação e na validação. Neste momento é preciso pensar como será a estruturação da organização, criando a sua arquitetura inicial, as suas primeiras especificações técnicas, quem será o time de trabalho, como será o layout da organização, como será a inserção da startup na Cadeia de Valor do seu negócio. Neste momento coloca-se a "mão na massa" efetivamente, abandonando a teoria, permitindo o favorecimento da venda pela experimentação do produto. Uma boa forma de economizar futuramente é validando o que será ofertado aos consumidores, mas deve se validar apenas o mínimo de forma a permitir a evolução da proposta de valor. É imprescindível para o projeto saber o momento em que se deve aprender e pivotar se for o caso, permitindo que a oferta seja colocada logo no mercado e receba feedback dos consumidores. É preciso ter consciência de que talvez seja preciso alterar o produto, retirando o que for irrelevante e mantendo o relevante, uma vez que incorporar os conhecimentos obtidos com os insights sempre é importante. É ainda uma forma de testar o mercado, de determinar os custos e de obter as primeiras impressões, podendo até mesmo mostrar novos usos para o produto e evitar problemas no futuro, já que reduz os riscos de se passar um longo tempo desenvolvendo algo que não será desejado, sendo a forma mais simples e barata de testar a aceitação do produto. Quando bem elaborado evidencia a necessidade do cliente e a sua proposta de resolução, podendo auxiliar com o preenchimento de lacunas de conhecimentos. Fornece organização sobre as ideias e sobre a representação do projeto, auxiliando no desenho da proposta de valor e na comunicação dos principais pontos do modelo de negócios, trabalhando com suas articulações e permitindo pensar especificamente no cliente, auxiliando no desenho de como o negócio deve gerar, entregar e sustentar valor para estes.

Ainda em conjunto com o Produto Mínimo Viável vale destacar o uso da etapa de Canvas do Value Proposition Design, uma vez que ambos são complementares e dinâmicos, auxiliando na validação da proposta de valor e minimizando esforços futuros para entrega de valor ao cliente. O essencial é um melhor entendimento do consumidor, envolvendo a compreensão do seu perfil e como será criado o valor. 
A Validação do Consumidor busca verificar se a organização estabeleceu uma proposta que corresponde aos desejos e necessidades dos consumidores. Como resultado tem-se a matriz de posicionamento, que auxilia no desenho do plano de negócios que será testado com consumidores que validarão ou não as suas propostas. Assim, é preciso identificar o momento em que o produto já pode ser considerado como validado, o que ocorre quando os consumidores deixam de agregar ideias de melhorias significativas. Para esta etapa ainda é essencial que o próprio empreendedor faça entrevistas de validação junto aos consumidores potencias, não devendo de forma alguma se distanciar destes. Neste momento também é essencial buscar as vendas, de forma a validar ou não tudo o que foi desenvolvido até o momento. Deve se buscar os feedbacks dos clientes em tempo real, sendo o momento de avaliar se 0 produto está atendendo as suas reais necessidades, minimizando os riscos de investimentos em aumento de escala. Auxilia como um indicador de mercado capaz de evidenciar se o que foi desenvolvido é o que as pessoas querem, sendo preciso estar aberto à mudanças. É uma etapa essencial para ajustes e melhorias.

$\mathrm{Na}$ Criação do Consumidor verifica-se o alinhamento entre a "dor do consumidor" e a proposta de valor da solução, caracterizando a comprovação final do valor do produto, auxiliando na criação da solução adequada. Uma ideia apenas vira um produto quando é efetivamente comprada, viabilizando a construção do preço, estabelecendo a porta de entrada do mercado. Caso não seja possível construir o mercado então é o momento de rever a startup.

Ao final da fase de Conversão deve-se obter a matriz de posicionamento da startup, que irá auxiliar no desenho do plano de negócios que será testado com os consumidores, que validarão ou não a sua proposta final. Quando a proposta for validada ocorrerá a criação de mercado, ponto que irá permitir a tomada de decisão de seguir, de caminhar para a etapa de Implementação e assim dar início à fase de Difusão, ou então de rever a continuidade da startup, retornar a etapa de Ideação do início da Conversão, caso a ideia central se mostre como relevante e apenas necessite de alguns ajustes ou então à fase de Imersão inicial do Framework Cíclico, quando a ideia central não foi considerada como válida pelos consumidores, ou não seja 
possível criar mercado de forma alguma, mas persista o desejo do empreendedor, de construir uma startup de sucesso.

Na etapa de Difusão ocorre a Implementação do Design Thinking e a $\underline{\text { Prototipação e Construção da Organização do Lean Startup, além do Business }}$ Model Canvas. $\mathrm{Na}$ Implementação com as etapas anteriores validadas é o momento de chegar ao produto final, sendo uma etapa natural e uma das mais importantes do processo, consistindo na maturação operacional para ganho de escala. As ideias selecionadas são transformadas em algo tangível para melhor avaliação, consistindo em colocar em prática o que foi validado pelo consumidor e permitiu a criação de mercado.

Como próxima etapa temos a Prototipação, que auxilia na validação e gera economia no desenvolvimento do produto, definindo a "cara do projeto" e evidenciando a sua usabilidade, permitindo sua validação antes de chegar ao desenvolvimento final. Funciona como um teste de campo funcional, testando a aceitação do mercado, eliminando possíveis erros futuros e ampliando as ideias, auxiliando na identificação de novas oportunidades. Neste momento cabe mencionar que poderão ser desenvolvidos versões que não serão necessariamente escaláveis, mas que são importantes pois auxiliam no processo de desenvolvimento do produto final.

A Prototipação deve ser desenvolvida em conjunto com o $\underline{\text { Business }}$ Model Canvas tendo em vista a validação das hipóteses estabelecidas, a partir dos feedbacks obtidos. Neste momento a ideia é materializada, permitindo o entendimento rápido da relação entre o modelo de negócio e a sua viabilidade, garantindo assertividade superior. A utilização do Business Model Canvas, traz planejamento e segurança para a operação, mostrando onde serão os investimentos do negócio e seu potencial, permitindo a organização dos principais pontos da startup, auxiliando no seu planejamento estratégico. É preciso se ter em mente que podem ocorrer mudanças no processo. A parte de custos e receitas deve ser bem detalhada para se errar menos ou até mesmo errar mais rápido.

$\mathrm{Na}$ Construção da Organização é o momento de desenhar a organização, estabelecer suas parcerias potenciais, construir o time de trabalho da organização (ponto muito importante), estabelecer a estrutura física da 
empresa, construir a missão, a visão e os valores, alinhando onde e como se quer chegar.

Vale destacar o uso em conjunto da Construção da Organização com o Business Model Canvas, pois a sinergia é significativa, uma vez que é preciso desenhar a organização para não se atuar "às escuras", unindo as pontas do círculo do projeto, estabelecendo o desenho da proposta de valor e a compreensão de como será estabelecida a vantagem competitiva, possibilitando a visualização e a comparação entre as propostas tendo em vista a escolha da melhor opção.

$\mathrm{Na}$ etapa de Difusão ocorre à propagação da ideia que será redesenhada com as melhorias do modelo validado, iniciando-se com a busca pela criação de um mercado para a organização. Neste ponto encerra-se o Framework Cíclico, sendo o momento de decidir se realmente deve-se seguir em frente ou reiniciar a startup por meio da geração de novas ideias e validação com os consumidores (iniciar na etapa de Imersão), ou até mesmo revalidar a ideia do negócio (iniciar na etapa de Ideação). Também pode ocorrer que ao final do Framework Cíclico verifique-se que a startup não deve ser continuada, devendo-se então iniciar todas as etapas na busca por novas ideias (Imersão) para gerar assim uma nova startup de sucesso. 


\section{CONSIDERAÇÕES FINAIS}

Após realizar leituras e análises sobre os temas Inovação, Design, Empreendedorismo e Modelos de Negócios, este estudo definiu como assuntos de interesse para a pesquisa os temas Cadeia de Valor da Inovação, Design Thinking, Lean Startup e Business Model Canvas e apresentou extensa revisão bibliográfica sobre os mesmos. Por serem temas recentes e ainda com pouca literatura relevante, o trabalho traz como contribuição seu alinhamento e integração em um referencial único para a geração e refinamento de conceitos, além da estruturação da operação inicial de negócios inovadores dando origem à um Framework Cíclico. Num cenário em que, segundo Wasim et al. (2013), os atuais efeitos da competição global forçam as organizações a estabelecerem estratégias de desenvolvimento de produtos e serviços que vão de encontro às expectativas e necessidades dos consumidores num curto espaço de tempo, com alta qualidade, com custo inferior e uma rápida resposta as mudanças, este Framework contribui significativamente com as inovações que provêm predominantemente de startups, novas organizações ou pequenas unidades em grandes organizações que sofrem com recursos de tempo e financeiros muitas vezes limitados, mas que em contrapartida são dinâmicas para implementar, testar e mudar, buscando a inovação como estratégia de sobrevivência.

Este estudo contribui com um novo referencial, que promove a geração de inovações com velocidade por meio da interação com o consumidor no desenvolvimento de novos produtos e serviços. Desta forma traz como contribuição a proposta de um novo Framework impulsionador de práticas inovadoras, combinando abordagens já existentes e em evidência, potencializando a complementaridade destas e gerando inovações com velocidade e interação com os consumidores. Este Framework é aplicável em startups pois é constituído com base em conceitos como prototipação, interação com o consumidor e obtenção de seus feedbacks, elaboração e teste rápido de hipóteses, não tendo como público alvo grandes organizações.

Esta pesquisa apresenta conhecimentos sobre o cenário experimentado pelas startups, contexto ainda recente e pouco explorado, sendo carente de pesquisa de relevância que possam auxiliar estes novos empreendimentos, 
principalmente em seus conturbados momentos iniciais. Para tanto buscou-se desenvolver um Framework que as auxilie e assim aumente o seu tempo de sobrevivência, auxiliando os empreendedores na busca dos seus sonhos. $O$ referencial também pode ser utilizado por atores do mercado financeiro,, pois estabelece referenciais capazes de viabilizar a análise sobre as principais etapas percorridas pelas startups em seu processo de concepção.

Como limitações deste estudo vale destacar a questão da amostragem, limitada apenas a startups em processo de aceleração ou aceleradas por aceleradoras brasileiras, de forma que não foi englobada na amostragem todas as modalidades de startups, uma vez que algumas são fruto de incubadoras, outras de programas organizacionais e algumas ainda surgem por iniciativa própria de seus fundadores. Outro ponto de limitação é a questão de que o Framework foi focado apenas em algumas abordagens de interesse, que se mostraram complementares e úteis. Assim permanece para estudos futuros a possibilidade de replicar o estudo com outra amostragem e também o teste do Framework Cíclico proposto por este estudo na realidade para a geração, refinamento e estruturação de startups. Outro aspecto que pode ser explorado em estudos futuros é o desenvolvimento de ferramentas de mensuração específicas para startups e seu processo de desenvolvimento, auxiliando em seu processo decisório de continuidade. Finalmente, vale destacar a oportunidade de estudos que foquem no detalhamento do processo de desenvolvimento de produtos e serviços nas startups, processo caracterizado como diferente do das grandes corporações. 


\section{REFERÊNCIAS BIBLIOGRÁFICAS}

ABRAHAM, S. Will Business Model Innovation Replace Strategic Analysis. Strategy \& Leadership, v. 41, n. 2, p. 31-38, 2013.

ABREU, P. R. M.; CAMPOS, N. M. C. O Panorama das Aceleradoras de Startups no Brasil. Create Space Independent Publishing Plataform, USA, Jul. 2016.

ALRECK, P. L.; SETTLE, R. B. The Survey Research Handbook. New York: Irwin Mc Graw-Hill, 2ed., 1995.

ANDERSON, J. Enabling Enterprise Kanban Transformation Throught Lean Startup Techniques. Lean Software \& Systems Conference, 2012.

ANDRÉ, A. M.; CIAMPONE, M. H. T.; SANTELLE, O. Tendências de Gerenciamento de Unidade de Saúde e de Pessoas. Prática de Saúde Pública, v. 47,n. 1, p. 158-163, 2013.

ARBIX, G. Estratégia de Inovação para o Desenvolvimento. Tempo Social: Revista de Sociologia da USP, v. 22, n. 2, p. 167-185, 2010.

ARRUDA, C.; NOGUEIRA, V.; COZZI, A.; COSTA, V. Causas da Mortalidade de Startups Brasileira. Fundação Dom Cabral, 2013.

AXELSSON, J.; PAPATHEOCHAROUS, E.; ANDERSSON, J. Characteristics of Software Ecosystems for Federated Embedded Systems: A Case Study. Elsevier: Informationand Software Tecnology, 2014.

BANCHIERI, L. C.; BLASCO, M. J.; CAMPA-PLANAS, F. Auto Evaluación de Lagestión por Parte de Pequeñas Empresas y Microempresas: Estudio Exploratorio. Intangible Capital, v. 9, n. 2, p. 477-490, 2013.

BECKMAN, S. L.; BARRY, M. Innovation as a Learning Process: Embedding Design Thinking. California Review Management, v. 50, n. 1, 2007.

BERTRAND, J.; WILL, M.; FRANSOO, J. C. Operations Management Research Methodologies use Quantitative Modeling. International Journal of Operations \& Production Management, v.22, n.2, p. 241-264, 2002.

BIANCOLINO, C. S.; MACCARI, E. A.; PEREIRA, M. F. A Inovação como Instrumento de Geração de Valor ao Setor de Serviços em TI. RGBN - Revista Brasileira de Gestão de Negócios, v. 15, n. 48, p. 410-426, Jul./Set. 2013.

BLANK, S. Embrace Failure to Start Up Sucess. Nature, v. 477, p. 133, Set. 2011

BLANK, S. The Four Steps to the Epiphany. Lulu Enterprises Incorporated, 2003.

BLANK, S. The Four Steps to the Epiphany. Hardcover, 2005.

BLANK, S. The Startup Owner's Manual: The Step-By-Step Guide for Building a Great Company. Hardcover, 2012.

BLOMBERG, A. Master Thesis: The Lean Startup Approach - and its Applicability Outside Silicon Valley. Copenhagen Business School, 2012.

BOCKEN, N.; SHORT, S.; RANA, P.; EVANS, S. A Value Mapping Tool for Sustainable Business Modelling. Corporate Governance, v. 13, n. 5, p. 482497, 2013. 
BONAZZI, F. L. Z.; ZILBER, M. A. Inovação e Modelo de Negócio: um Estudo de Caso sobre a Integração do Funil de Inovação e o Modelo Canvas. RBGN Revista Brasileira de Gestão de Negócios, v. 16, p. 53, p. 616-637, Out./Dez. 2014.

BOOTE, D. N.; BEILE, P. Scholars Before Researchers: on the Centrality of the Dissertation Literature Review in Research Preparation. Educational Researcher, v. 34, n. 6, p. 3-15, Ago./Set. 2005.

BRERETON, P.; KITCHENHAM, B. A.; BUDGEN, D.; TURNER, M.; KHALIL, M. Lessons from Applying the Sustematic Literature Review Process Within the Software Engineering. The Journal of Systens and Software, v. 80, p. 571583, 2007.

BROWN, T. Design Thinking. Harvard Business Review, Jun. 2008.

BROWN, T. Design Thinking - Uma Metodologia Poderosa para Decretar o Fim das Velhas Ideias. Elsevier, 2010.

BUCHANAN, R. Wicked Problems in Design Thinking. Design Issues, v. 8, n. 2, p. 5-21, 1992.

CABANELAS, P.; OMIL, J. C.; VÁZQUEZ, X. H. A Methodology for the Construction of Dynamic Capabilities in Industrial Networks: The Role Of Border Agents. Elsevier: Industrial Marketing Management, 2013.

CARVALHO, M. M. Inovação: Estratégias e Comunidades de Conhecimento. São Paulo: Editora Atlas S. A., 2009.

CASADESUS-MASANELL, R.; RICART, J. E. From Strategy to Business Models and Onto Tactics. Long Rang Planning, v. 43, p. 195-215, 2010.

CHEN, S.; CHENG, A.; MEHTA, K. A Review of Telemedicine Business Model. Telemedicine e E-Health, v. 19, n. 4, Abr. 2013.

CHERIF, E.; GRANT, D. Analysis of E-Business Model in Real State. Springer: Electronic Commerce Research, 2013.

CHESBROUGH, H. W. The Era of Open Innovation. Springer: MIT Sloan Management Review, v. 44, n. 3, 2003.

CHESBROUGH, H. W.; TEECE, D. J. Organizing for Innovation: When is Virtual Vistuous?. Harvard Business Review, Boston, Jan.-Fev. 1996.

CHRISTIAANS, H.; VENSELAAR, K. Creativity in Design Engineeringand The Role of Knowledge: Modelling The Expert. International Journal of Technology and Design Education, v. 15, p. 217-236, 2005.

COBB, N. K.; POIRIER, J. Implementation of an Online Pragmatic Randomized Controlled Trial: A Methodological Case Study. Washington: Division of Pulmonary \& Critical Care, Department of Medicine, Georgetown University Medical Center, v. 3, p. 295-303, 2013.

COOPER, B.; VLASKOVITS, P. The Entrepreneur's Guide to Customer Development: A Cheat Sheet to The Four Steps to The Epiphany. Paperback, Jul. 2010.

CROLL, A.; YOSKOVITZ, B. Lean Analytics: Use Data to Build a Better Startup Faster. The Lean Series, 2013.

CROSS, N. Designerly Ways of Knowing. Springer, 2006. 
CRUZ, R. Por Que Empresas que Mudam o Mundo Nascem no Vale. 2011 Disponível em: http://economia.estadao.com.br/noticias/geral,por-queempresas-que-mudam-o-mundo-nascem-no-vale-imp-,768172. Acesso em 8 de outubro de 2015.

DAFT, R. L. Why I Recommended That Your Manuscript Be Rejected and What You Can do About It. Organizational Sciences, p. 193-209, Jun. 1985.

DAVILA, T. As Regras da Inovação: Como Gerenciar, Como Medir e Como Lucrar. Porto Alegre: Bookman, 2009.

DEMO, P. Metodologia do Conhecimento Científico. São Paulo: Editora Atlas, $1^{\underline{a}}$ ed., $3^{3}$ tir., 2000.

DENZIN, N. K.; LINCOLN, Y. S. Handbook of Qualitative Research. London, Sage Publication, 1994.

DORAN, J. e O'LEARY, E. External Interaction, Innovation and Productivity: An Application of The Innovation Value Chain to Ireland. Spatial Economic Analysis, v. 6, n. 2, Jun. 2011.

DORST, K. The Core of 'Design Thinking' and its Application. Elsevier: Design Studies, v. 32, n. 6, Nov. 2011.

DORST, K.; CROSS, N. Creativity in the Design Process: Co-Evolution Of Problem-Solution. Elsevier Science Ltda: Design Studies, v. 22, p. 425-437, 2001.

DRUCKER, P. F. Administração em Tempos Turbulentos. São Paulo: Pioneira, 1980.

DUNNE, D.; MARTIN, R. Design Thinking and How it Will Change Management Education: An Interview and Discussion. Academy of Management Learning \& Education, v. 5, n. 4, p. 512-523, 2006.

DYM, C. L.; AGOGINO, A. M.; ERIS, O.; FREY, D. D.; LEIFER, L. J. Engineering Design Thinking, Teaching, And Learning. Journal of Engineering Education, Jan. 2005.

EDISON, H. A Conceptual Framework of Lean Startup Enabled Internal Corporate Venture. Springer International Publishing Switzerland, p. 607613, 2015.

EISENHARDT, K. M. Building Theories From Case Study Research. Stanford University, Academy of Management Preview, v. 14, n. 4, p. 532-550, 1989.

FIGUEIREDO FILHO, D. B.; SILVA Jr., J. A. Visão além do Alcance: uma Introdução à Análise Fatorial. Opinião Pública, Campinas, v.16, n.1, p. 160185, 2010.

FLICK, U. Uma Introdução à Pesquisa Qualitativa. Porto Alegre: Bookman, 2004.

FORZA, C. Survey Research in Operations Management: a Process-Based Perspective. Internacional Journal of Operations \& Production Management, Italy: Università di Padova, v. 22, n. 2, p. 152-194, 2002.

GALL, M. D.; BORG, W. R.; GALL, P. J. Education Research: An Introduction. White Plain, New York: Longman, 6 ed., 1996. 
GANOTAKIS, P.; LOVE, J. H. The Innovation Value Chain in New TechnologyBased Firms: Evidence From The U. K., Product Development \& Management Association. v. 29, n. 5, p. 839-860, 2012.

GELBMANN, U.; HAMMERL, B. Integrative Re-Use Systems as Innovative Business Models for Devising Sustainable Product-Service-System. Elsevier: Journal of Cleaner Production, 2014.

GEPHAT, JR.; ROBERT,P. From the Editors: Qualitative Research and the Academy of Management Journal. Academy of Management Journal, University of Alberta, v.47, n.4, p. 454-462, 2004.

GESTÃO DE PROJETOS NA PRÁTICA. Disponível em: http://www.elirodrigues.com/2012/08/06/por-que-o-pmbok-nao-e-umametodologia/. Acesso em 11 de fevereiro de 2017.

GHEZZI, A. Emerging Business Models and Strategies for Mobile Platform Providers: A Reference Framework. Emerald Group Publishing Limited, v. 14, n. 5, p. 36-56, 2012.

GIARDINO, C.; WANG X.; ABRAHAMSSON, P. Why Early-Stage Software Startups Fail: A Behavioral Framework. Springer International Publishing Switzerland, p. 27-41, 2014.

GITAHY, Y. O que é uma startup?. 2010 Disponível em: http://exame.abril.com.br/pme/noticias/o-que-e-uma-startup?page=1. Acesso em 26 de setembro de 2015.

GOOGLE FINANCE. Nasdaq Composite. Disponível em: https://www.google.com/finance?q=INDEXNASDAQ:.IXIC\&sq=nasdaq\&sp=1\&e i=HF8VVoDzLcTNeZ3Ss9AK. Acesso em 8 de outubro de 2015.

GUEDES, P. Startup Rio. 2015. Disponível em: http://oglobo.globo.com/opiniao/startup-rio-17279960. Acesso em 26 de setembro de 2015.

HADIDA, A. L.; PARIS, T. Managerial Cognition and the Value Chain in the Digital Music Industry. Technological Forecasting \& Social Change. v. 83, p. 84-97, 2014.

HAIR, J.F.; BLACK, W.C.; BABIN, B.J.; ANDERSON, R.E. Multivariate Data Analysis. Seventh Edition, Prentice Hall, Upper Saddle River, New Jersey, 2010.

HANSEN, M. T.; BIRTINSHAW, J. The Innovation Value Chain. Harvard Business Review, Jun. 2007.

HARMS, R. Self-Regulated Learning, Team Learning and Project Performance in Entrepreneurship Education: Learning in a Lean Startup Environment. Technological Forecasting \& Social Change, p. 21-28, 2015.

HARTMANN, V. H. P. Startup: Uma Nova Forma de Empreender. Faculdade de Tecnologia e Ciências Sociais Aplicadas - FATECS, 2013.

HITT, M. A.; IRELAND, R. D.; HOSKISSON, R. E. Administração Estratégica. São Paulo: Thomson, 2005.

IACOB, M. E.; MEETENS, L. O.; JONKERS, H.; QUARTEL, D. A. C.; NIEUWENHUIS, L. J. M.; SINDEREN, M. J. From Enterprise Architecture to 
Business Models and Back. Springer-Verlag Berlin Heidelberg, Software System Model, 2012.

ICSID - International Concil of Societies of Industrial Design. Disponível em: http://icsid.org. Acesso em 20 de agosto de 2016.

IDEO. Design Thinking for Educators. 2 ed., Toolkit, 2012.

JÄRVI, A.; TAAJAMAA, V.; HYRYNSALMI, S. Lean Software Startup - An Experience Report from an Entrepreneurial Software Business Course. Springer International Publishing Switzerland, p. 230-244, 2015.

JOHANSSON-SKÖLDBERG, U.; WOODILLA, J.; ÇETINKAYA, M. Design Thinking: Past, Present and Possible Futures. John Wiley \& Sons Ltda, v. 22, n. 2, 2013.

KARLSSON, J.; NORDSTRÖM, J. Implementing Lean Startup Methodology in Large Firms - Benefits, Challenges and Solutions. Sweden: Department of Technology Management and Economics, Division of Innovation Engineering and Management, Chalmers University of Technology, 2012.

KENNEY, M. Understanding Silicon Valley: The Anatomy of an Entreprenerial Region Stanford University Press. California. 2000.

KISS, A. N.; DANIS, W. M.; CAVUSGIL, S. T. International Entrepreneurship Research in Emerging Economies: A Critical Review and Research Agenda. Elsevier: Journal of Business Venturing, v. 27, p. 266-290, 2012.

KLASSEN, R. D; JACOBS, J. Experimental Comparison of Web, Eletronic and Mail Survey Technologies in Operations Management. Journal of Operations Management, v. 19, p. 713-728, 2001.

KOTLER, P. Administração de Marketing. São Paulo: Prentice Hall, 12 ed., 2006.

LAWSON, B.; DORST, K. Design Expertise. Routledge, 2013.

LENZI, F. C.; KIESEL, M. D.; ZUCCO, F. D. Ação Empreendedora. Gente, 2010.

LEUNG, A.; ZHANG, J.; WONG, P.; FOO, M. D. The Use of Networks in Human Resource Acquisition for Entrepreneurial Firms: Multiple "Fit" Considerations. Elsevier: Journal of Business Venturing, v. 21, p. 664-686, 2006.

LOVE, H. J.; ROPER, S.; BRYSON, J. R. Openness, Knowledge, Innovation and Growth in UK Business Service. Elsevier: Research Policy, v. 40, p. 1438-1452, 2011.

LUCENA, J. P.; CASACA, J. O Valor Econômico das Marcas dos "Três Grandes" do Futebol Português. Revista Portuguesa e Brasileira de Gestão, Jul.-Set. 2013.

MANUAL DE OSLO - Diretrizes para Coleta e Interpretação de Dados sobre Inovação. 3 ed., 1997.

MARTIKAINEN, A.; NIEMI, P.; PEKKANEN, P. Developing a Service Offering for a Logistical Service Provider - Case of Local Food Supply Chain. Elsevier: International Journal of Production Economics, 2013. 
MAURYA, A. Running Lean: Iterate from Plan A To A Plan That Works. O'Reilly, 2012.

MCVEA, J. F. A Field Study of Entrepreneurial Decision-Making and Moral Imagination. Journal of Business Venturing, p. 491-504, 2009.

MELO, C. O.; SANTOS, V.; KATAYAMA, E.; CORBUCCI, H.; PRIKLADNICKI, R.; GOLDMAN, A.; KON, F. The Evolution of Agile Software Development in Brazil - Education, Research, and The State-Of-The-Practice. Springer: The Brazilian Computer Society, v. 19, p. 523-552, 2013.

MICHELI, P.; JAINA, J.; GOFFIN, K.; LEMKE, F.; VERGANTI, R. Perceptions of Industrial Design: The "Means" and The "Ends". Journal Production Innovation Management, p. 687-704, 2012.

MIGUEL, G. F. Fatores Condicionantes para o Surgimento de Novos Polos de Desenvolvimento e Empreendedorismo para Empresas de Base Tecnológica de Comunicação e Informação Digital: Estudo de Caso Vale do Silício. São Paulo: Escola de Comunicação e Artes da Universidade de São Paulo. Disponível em: http://grupo-ecausp.com/digicorp/wpcontent/uploads/2015/05/GUILHERME-FERNANDES-MIGUEL.pdf. Acesso em 8 de outubro de 2015.

MIGUEL, P. A. Metodologia de Pesquisa em Engenharia de Produção e Gestão de Operações. Rio de Janeiro: Elsevier, 2010.

MIGUEL, P. A. C. QFD no Desenvolvimento de Novos Produtos: Um Estudo sobre a sua Introdução em uma Empresa Adotando a Pesquisa-Ação como Abordagem Metodológica. Produção, v. 19, n. 1, p. 105-128, Jan.-Abr. 2009.

MILLER, P.; BOUND, K. The Startups Factories: The Rise of Accelerator Programmes to Support New Technology Ventures. Making Innovation Flourish, Jun. 2011.

MUELLER, R. M.; THORING, K. Design Thinking Vs. Lean Startup: A Comparison of Two User-Driven Innovation Strategies. Boston: International Design Management Research Conference, Ago. 2012.

NATIONAL VENTURE CAPITAL ASSOCIATION DOS EUA. Disponível em: http://nvca.org/. Acesso em 15 de outubro de 2015.

NIELSEN, C.; MONTEMARI, M. The Role of Human Resources in Business Model Performance: The Case of Network-Based Companies. Journal of Human Resource Costing \& Accounting, v. 16, n. 2, 2012.

NIRWAN, M. D.; DHEWANTO, W. Barriers in Implementing the Lean Startup Methodology in Indonesia - Case Study of B2B Startup. The 6th Indonesia International Conference on Innovation, Entrepreneurship and Small Business, p. 23-30, Ago. 2015.

NOVAES, R. Conheça a História do Vale do Silício e suas Primeiras Empresas!. 2014. Disponível em: http://www.psafe.com/blog/conheca-valesilicio/. Acesso em 26 de setembro de 2015.

OSTERWALDER, A.; PIGNEUR, Y.; BERNARDA, G.; SMITH, A.; PAPADAKOS, T. Value Proposition Design: How to Create Products and Services Customers Want (Strategyzer), Paperback, Out. 2014.

OSTERWALDER, A.; PIGNEUR, Y. Business Model Generation. Wiley, 2010. 
PATTON, M. Q. Qualitative Evaluation and Research Methods. London: Sage, 1990.

PAUWELS, C.; CLARYSSE, B.; WRIGHT, M.; HOVE, J. V. Understanding a New

Generation Incubation Model: The Accelerator. Technovation, 2015.

PAYNE, S. L. The Art of Asking Questions. Princeton: Princeton University Press, 1951.

PE'ER, A.; KEIL, T. Are All Startups Affected Similarly By Clusters? Agglomeration, Competition, Firm Heterogeneity, and Survival. Elsevier: Journal of Business Venturing, 2012.

PÉREZ, J. E.; MARTíNEZ, A. C. Validez de Contenido y Juicio de Expertos: Una Approximación a su Utilización. Avances en Medición, v. 6, p. 27-36, 2008.

POPPENDIECK, M.; CUSUMANO, M. A. Lean Software Development: A Tutorial. IEEE Software, IEEE Computer Society, v. 29, p. 26-32, 2012.

PRÉ, L.; LECOCQ, X.; ANGOT, J. Costumer-Integrated Business Models: A Theoretical Framework. Management, v. 13, n. 14, p. 226-265, 2010.

RANDOLPH, J. J. Practical Assessment Research e Evaluation: A Guide to Writing the Dissertation Literature Review. Practical Assessment, Research \& Evaluation, v. 14, n. 13, Jun. 2009.

RASINSKI, K. A. Survey: Encyclopedia of Social Measurement. Chicago: University of Chicago, v. 3, 2005.

RASMUSSEN, E. S.; TANEV, S. The Emergence of the Lean Global Startup as a New Type of Firm. Technology Innovation Management Review, v. 5, n. 11, Nov. 2015.

RIES, E. The Lean Startup: How Today's Entrepreneurs use Continuous Innovation to Create Radically Successful Businesses. Crown Business, 2011.

RISKU, J.; ABRAHAMSSON, P. What Can Software Startuppers Lean from the Artistic Design Flow? Experiences, Reflections and Future Avenues. Springer International Publishing Switzerland, p. 584-599, 2015.

RITTEL, H.; WEBBER, M. Dilemmas in a General Theory of Planning. Holanda: Policy Sciences, v. 4, v. 2, p. 155-169, Jun. 1973.

RIZÉRIO, L. Há 13 anos, Bolha da Internet Começa a Explodir nos EUA; Veja como foi. 2013. Disponível em: http://www.infomoney.com.br/mercados/acoes-e-indices/noticia/2698151/anosbolha-internet-comecava-explodir-nos-eua-veja-como-foi. Acesso em 26 de setembro de 2015.

ROPER, S.; DU, J.; LOVE, J. H. Modelling The Innovation Value Chain. Elsevier Research Polity, v. 37, p. 961-977, 2008.

SALERNO, M. S.; GOMES, L. A. V.; SILVA, D. O.; BAGNO, R. B.; FREITAS, S. L. T. U. Innovation Process: Which Process for which Project?. Technovation, v. 35, p. 59-70, 2015. 
SARAVASTHY, S. D. Causation and Effectuation: Towards A Theoretical Shift From Economic Inevitability to Entrepreneurial Contingency. Academy of Management Review, v. 26, n. 2, p. 243-263, 2001.

SCHON, D. A.; WIGGINS, G. Kinds of Seeing and Their Functions in Designing. Butterworth-Heinemann Ltd, Design Studies, v. 13, n. 2, Abr. 1992.

SILVA, S. E. P.; CALADO, R. D.; SILVA, M. B.; NASCIMENTO, M. A. Lean Startup Applied in Healthcare: A Viable Methodology for Continuous Improvement in The Development of New Products and Services. 6th International Conference on Management and Control of Production and Logistics, 2013.

SIMON, H. A. The Structure of III Structured Problems. North-Holland Publishing Company: Artificial Intelligence, p. 181-201, 1973.

SINKOVICS, N.; SINKOVICS, R. R.; YAMIN, M. The Role of Social Value Creation in Business Model Formulation at The Bottom of The Pyramid Implications for MNEs. Elsevier: International Business Review, 2014.

SKJONG, R.; WENTWORTH, B. Expert Judgement and Risk Perception. International Offshore and Polar Engineering Conference, Stavenger: Norway, 2000.

SLEUWAEGEN, L. Scanning for Profitable (International) Growth. Emerald: Journal of Strategy and Management, v. 6, n. 1, p. 96-110, 2013.

SORENSEN, F.; MATTSON, J.; SUNDBO, J. Experimental Methods in Innovation Research. Research Policy 39, v. 61, n. 2, p. 313-322, 2010.

SUTTON, R. I.; STAW, B. M. What Theory is Not. Administrative Science Quarterly, v. 40, n. 3, p. 371-385, Set 1995.

TABACHNICK, B. G.; FIDELL, L. S. Using Multivariate Statistics. Handcover, 2012.

TAMAMAR, G.; JAKITAS, R. Empresas se Aproximam de Startups em Busca de Inovação: Um Exemplo é a Braskem, que Lançou um Programa para Incentivar Soluções por Meio do Plástico. 2015 Disponível em: http://pme.estadao.com.br/noticias/noticias,empresas-se-aproximam-de-startups-embusca-de-inovacao,5722,0.htm. Acesso em 19 de outubro de 2015.

TAUBERER, J. Inventing Open Government: Internet Startup POPVOX Connects Constituents to Congress in a Play to Disrupt the World of Advocacy. XRDS, v. 18, n. 2, p. 9-11, 2011.

TERHO, H.; SUONSYRJÄ, S.; KARISALO, A.; MIKKONEN, T. Ways to Cross the Rubicon: Pivoting in Software Startups. Springer International Publishing Switzerland, p. 555-568, 2015.

THIEL, P.; MASTERS, B. Zero to One: Notes on Startups, or How to Build the Future. Crown Business, Set. 2014.

TIDD, J.; BESSANT, J.; PAVITT, K. Gestão da Inovação. Porto Alegre: Bookman, 2008.

TIMMERS, P. Business Models for Eletronic Markets. CommerceNet, Set. 1998. 
TRIMI, S.; BERBEGAL-MIRABENT, J. Business Model Innovation in Entrepreneurship. Springer: International Entreprise Management Journal, p. 449-465, 2012.

TULL, S. D.; HAWKINS, L. D. Marketing Research: Meaning, Measurement and Method. New York: Macmillan Publishing Co. Inc., 1990.

VARANDAS JUNIOR; A.; SALERNO, M. S.; MIGUEL, P. A. C. Análise da Gestão da Cadeia de Valor da Inovação em uma Empresa do Setor Siderúrgico. Gestão e Produção, v. 21, n. 1, p. 1-18, 2014.

VIANNA, M.; VIANNA, Y.; ADIER, I. K.; RUSSO, B. Design Thinking - Inovação em Negócios. 1 ed., MJV Press, Abr. 2011.

WASIM, A.; SHEHAB, E.; ABDALLA, H.; AL-ASHAAD, A.; SULOWSKI, R.; ALAM, R. An Innovative Cost Modelling System to Support Lean Product and Process Development. International Journal Adventure Manufacturing Technology, p. 165-181, 2013.

WEBSTER, J.; WATSON, R. T. Analyzing The Past to Prepare for The Future: Writing A Literature Review. MIS Quarterly, n. 26, v. 2, 2002.

WELLS, A. The Importance of Design Thinking for Technological Literacy: A Phenomenological Perspective. International Journal of Technology Design Education, p. 623-636, 2013.

WITELL, L.; LÖFGREN, M. From Service for Free to Service tor Fee: Business Model Innovation in Manufacturing Firms. Emerald: Journal of Service Management, v. 24, n. 5, p. 520-533, 2013.

YANG, M. G. M., HONG, P., MODI, S. B. Impact of Lean Manufacturing and Environmental Management on Business Performance: An Empirical Study of Manufacturing Firms. International Journal of Production Economics. v. 129, n. 2, pg. 251-261, 2011.

YEN, M.; DRINKA, D.; KANAMORI, Y. Exploring and Evaluating E-Business Models: A Preliminary Study of a Community-Based Website. Communication of the IIMA, v. 13, n. 3, 2013.

ZOTT, C.; AMIT, R.; MASSA, L. The Business Model: Recent Developments and Future Research. Journal of Management, 2011. 


\section{ANEXO 1 - Questionário de testes antes da Qualificação}

\section{ETAPA 1}

Qual o nome da empresa?

A quanto tempo a empresa está no mercado?

Qual o ramo da empresa? O que levou os fundadores da empresa a optarem por este ramo?

Como a empresa define o mercado em que está inserida? Questões competitivas, ambiente, estratégias, fatores de sucesso.

Como surgiu e evoluiu a ideia de construir a empresa?

Quando a empresa foi idealizada os recursos para a constituir eram limitados? Se sim, quais?

Considera que a empresa:

( ) Descobriu que existem clientes com um problema a ser resolvido e que estes estão dispostos a pagar pela solução deste problema.

( ) Descobriu que realmente vale a pena resolver o problema dos clientes e já o está tentando resolver.

( ) Já desenvolveu sua proposta de resolução de problemas dos clientes e a está divulgando.

( ) Está focada em receita, em a otimizar, já tendo uma solução de problemas dos clientes inserida no mercado.

( ) Está expandindo o seu mercado, buscando novos consumidores, tendo ou não mais canais de distribuição.

Como a empresa define inovação? 


\section{ETAPA 2}

\section{Cadeia de Valor da Inovação}

No momento de criar a empresa a geração das ideias foram da própria empresa?

Ocorreu algum tipo de trabalho em equipe para gerar as ideias da empresa?

A empresa recorreu a fontes externas para gerar as ideias?

A empresa é boa para selecionar e dar continuidade a novas ideias?

A empresa é boa em transformar as ideias em produtos e negócios? Quais as dificuldades encontradas?

A empresa é boa em difundir suas ideias no mercado? Quais as dificuldades encontradas?

Pensando nas questões abaixo como etapas, A empresa as seguiu? Como isso foi desenvolvida? Todas são válidas, quais são as críticas e sugestões para estas?

( ) Geração de Ideias (geração de ideias internamente)

( ) Conversão (triagem das ideias e continuidade inicial destas)

( ) Difusão (disseminação das ideias)

\section{Design Thinking}

Quando a empresa foi idealizada ocorreu a preocupação de ser criativo no que seria ofertado, a busca por novas oportunidades, Como?

No processo de idealização da empresa participaram pessoas de perfis diversos? 
Pensando nas questões abaixo como etapas, A empresa as seguiu? Como isso foi desenvolvida? Todas são válidas, quais são as críticas e sugestões para estas?

( ) Imersão (entendimento completo da situação)

( ) Análise e Síntese (consolidação do entendimento estabelecendo padrões e conexões)

( ) Ideação (onde as ideias são geradas e avaliadas)

( ) Prototipação (tornar as ideias mais promissoras tangíveis)

Quais ferramentas foram utilizadas? Quais as contribuições destas para a organização?

( ) Brainstorming (chuva de ideias)

( ) Workshop de Co-criação (uma série de atividades em grupo para estimular a criatividade)

( ) Personas (personagens com perfis distintos que simulam os clientes potenciais)

( ) Mapa de Empatia (quadro que sintetize o que consumidores potenciais pensam, sentem...)

( ) Jornada do Usuário (representação gráfica das etapas de relacionamento com os clientes)

( ) Blueprint (representação gráfica das interações entre a empresa e os clientes)

( ) Diagrama de Afinidades (categorização das informações em cartões)

( ) Cardápio de Ideias (catálogo sintetizador das ideias geradas)

( ) Matriz de Posicionamento (seleção das ideias mais relevantes para prototipação, consultando as necessidades das personas)

( ) Protótipo em Papel (exemplo do negócio a ser desenvolvido em papel)

( ) Modelo de Volume (exemplo mais concreto do negócio a ser desenvolvido)

( ) Encenação (dramatização do atendimento ao cliente)

( ) Storyboard (recursos visuais para contar a história do atendimento aos clientes)

( ) Protótipo de Serviços (simulação da oferta de serviços aos clientes)

( ) Outras

\section{Business Model Canvas}

Como a empresa acredita criar valor para os clientes? 
É possível visualizar a criação de valor da empresa para os clientes olhando o modelo de negócios da empresa?

Ocorreu um desenho prévio da criação de valor da empresa para os clientes ou esta não foi pensada de forma clara antes da entrada no mercado?

Pensando nas questões abaixo como etapas, A empresa as seguiu? Como isso foi desenvolvida? Todas são válidas, quais são as críticas e sugestões para estas?

( ) Segmentos de Consumo (os consumidores são agrupados em grupos de acordo com suas necessidades comuns)

( ) Proposição de Valor (conjunto de produtos/serviços que a organização irá ofertar para o seu segmento de consumidores alvo)

( ) Canais (são os Canais de Vendas, Distribuição e Comunicação, como a organização irá se comunicar para entregar valor como seu segmento de consumidores alvo)

( ) Relação com o Consumidor (determinação do tipo de relação que a organização pretende desenvolver com o segmento de consumidores alvo)

( ) Fontes de Receitas (representa o rendimento de cada segmento de consumidores atendidos pela organização)

( ) Recursos Chave (são os recursos que permitem a organização criar valor)

( ) Atividades Chave (criam e propõe valor de forma a manter a organização rentável e os seus consumidor fidelizados)

( ) Parcerias Chave (trata da relação com os parceiros que auxiliam a organização no seu funcionamento perfeito)

( ) Estrutura de Custos (mostram todos os custos da organização) 


\section{Lean Startup}

O idealizador da empresa foi a campo para o melhor entendimento do consumidor?

Quando a empresa foi idealizada antes do lançamento dos produtos ou serviços ocorreu a coleta de feedback de clientes potenciais? Se sim, como foi desenvolvido este processo?

A empresa possui preocupação com o feedback dos clientes? Estão são coletados? Como?

Como os clientes avaliam a importância do feedback dos clientes? A empresa busca aprender com os clientes?

A empresa emprega melhorias em suas propostas de produtos e serviços com base no feedback de clientes?

A empresa já identificou mais sucesso com as vendas após o emprego da opinião dos consumidores?

Pensando nas questões abaixo como etapas, A empresa as seguiu? Como isso foi desenvolvida? Todas são válidas, quais são as críticas e sugestões para estas?

( ) Descoberta do Consumidor (entendimento do problema, coleta de informações relacionadas ao problema)

( ) Validação do Consumidor (realizar os testes de hipóteses junto aos consumidores, momento que é decidido entre prosseguir ou retornar com a ideia)

( ) Criação do Consumidor (busca por criar demanda)

( ) Construção da Organização (propagação das ideias por toda a organização e a busca de sua efetiva construção) 


\section{ETAPA 3}

Quando a empresa foi constituída ocorreu a proposta de mais de um modelo de negócio para ouvir as opiniões dos clientes antes de iniciar a empresa de forma definitiva?

A organização utilizou de metodologias para grandes organizações, como guia no seu desenvolvimento por não encontrar metodologias para novas empresas?

Algo auxiliou a organização no momento de decidir pela oferta de produto ou serviços em escala?

A empresa sentiu que possuía disponível todo o material relacionado a itens como passos a seguir, cases que era necessário para iniciar, ou sentiu falta de material? Do que mais a organização sentiu falta? 


\section{ANEXO 2 - Questionário dos Especialistas em Startups}

Prezado Especialista,

Solicitamos sua valiosa colaboração na avaliação de uma proposta de "framework para estruturação de startups", parte da pesquisa de mestrado da aluna Diane dos Reis, do curso de Pós-Graduação em Engenharia de Produção da Universidade de São Paulo.

O framework visa contribuir com as startups em seu processo de concepção, auxiliando na geração e refinamento de negócios inovadores e foi elaborado a partir dos resultados obtidos com a exploração de modelos de diferentes áreas de conhecimento: Cadeia de Valor da Inovação, Design Thinking, Lean Startup e Business Model Canvas.

A Figura 1 apresenta este framework incluindo suas fases e conjuntos de atividades que podem ser executados por startups na busca por negócios inovadores. Neste momento cabe mencionar que a única abordagem utilizada por mais de uma vez dentro do framework é o Business Model Canvas, pois foi considerado válida a sua elaboração completa sempre que seja necessária uma boa visualização e validação do que está sendo desenvolvido (fases de Mínimo Produto Viável, Prototipação e Construção da Organização).

Diane dos Reis, Programa de Pós Graduação em Engenharia de Produção da Universidade de São Paulo. Contatos: (11) 98503.2725 / diane.reis@hotmail.com. 
Figura 1 - Framework

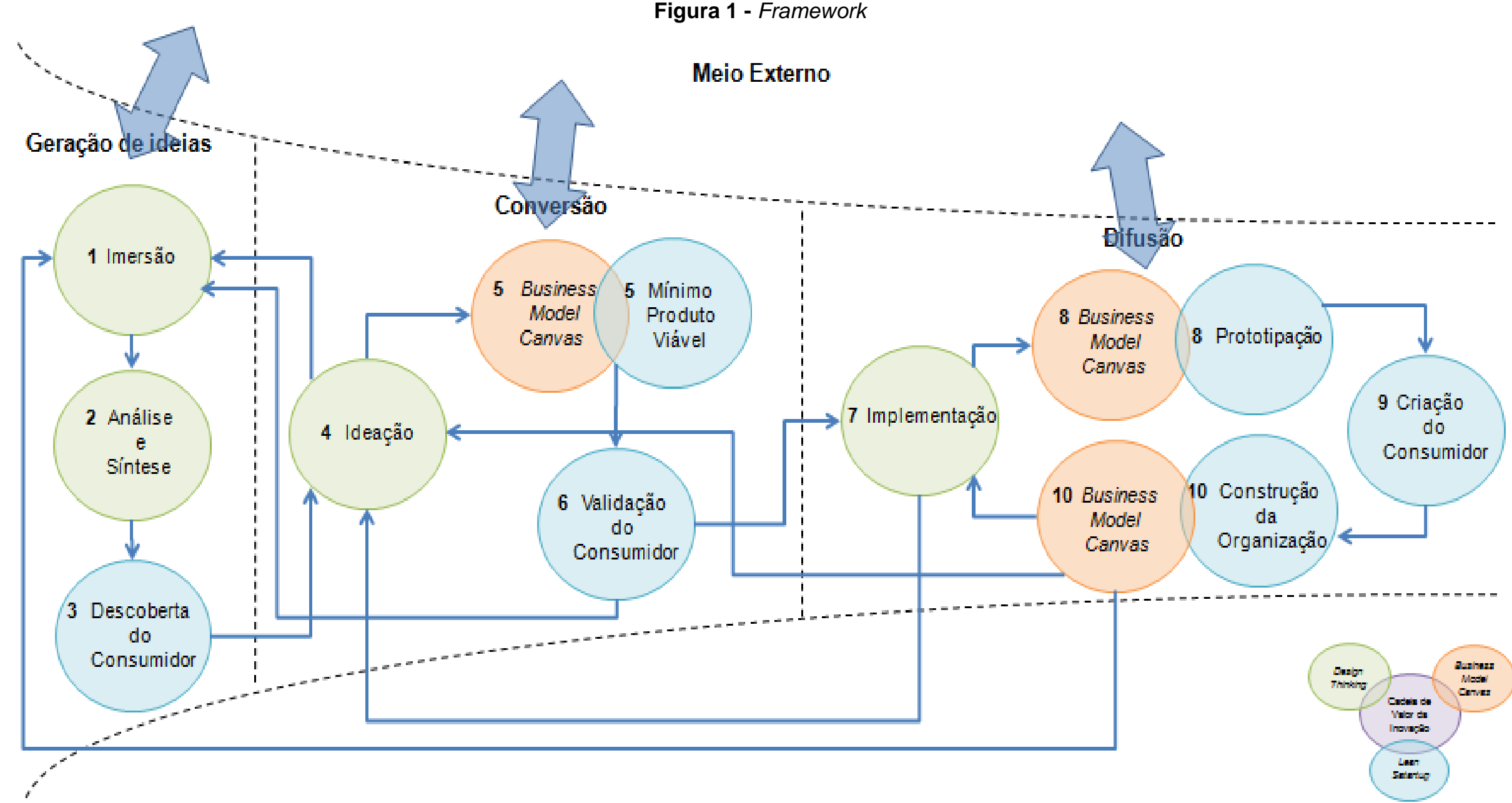

Fonte: Elaborado pela autora. 


\section{Questões de Controle}

Estas informações serão usadas para classificação das respostas, seu preenchimento é opcional.

1 Qual seu nome completo?

2 Qual sua idade?

3 Formação acadêmica? (exemplo: graduação em Engenharia de Produção)

( ) Graduação

( ) Doutorado

( ) Pós-graduação

( ) Pós-doutorado

( ) Mestrado

( ) Outros

4 Gênero?

( ) Feminino

( ) Masculino

$5 \quad$ Quantidade de anos de atuação junto às startups?

\section{Geração de Ideias}

É o momento em que se inicia o desenvolvimento de algo novo, usualmente combinando diferentes ideias, aprimoradas com os conhecimentos trazidos pelas diferentes partes interessadas. As ideias podem ser geradas internamente pela organização e combinadas com ideias provenientes de fontes externas à empresa. Desta forma, os conhecimentos utilizados podem ser externos ou internos à organização.

Neste framework a fase de Geração de Ideias inclui as etapas de "Imersão", amplo levantamento de informações, e "Análise e Síntese", consolidação das informações previamente obtidas, ambos provenientes do Design Thinking, além da etapa de "Descoberta do Consumidor", que busca identificar os consumidores interessados pelas inovações em desenvolvimento, proveniente do Lean Startup. Como resultado desta fase espera-se o entendimento da situação a ser solucionada, a consolidação dos conhecimentos sobre o consumidor a quem se destina esta solução e a efetiva geração de ideias com foco nos consumidores.

$\mathrm{Na}$ sua opinião o processo de Geração de Ideias, ou seja, o desenvolvimento de novos conceitos inovadores para produtos e serviços, inclui apenas e 
necessariamente as etapas de Imersão, Análise e Síntese e Descoberta do Consumidor?

( ) Sim ( )Não

Se não, quais etapas estão a mais? Sentiu falta de outras etapas?

1 Imersão: busca o entendimento do ambiente, do mercado e dos segmentos de clientes de interesse; usualmente inclui ampla pesquisa sobre estes tópicos, aplicando técnicas como benchmarks, levantamento da voz do cliente, pesquisas bibliográficas, entre outros.

Na sua opinião a fase de "Imersão" é:

( )Muito Relevante ( )Relevante ( )Indiferente( )Pouco Relevante ( )Irrelevante Pontos relevantes em relação a fase de "Imersão":

2 Análise e Síntese: consolida as informações obtidas na Imersão e busca estabelecer padrões e conexões entre estas utilizando de técnicas como personas, mapa de empatia e jornada do usuário.

Na sua opinião a fase de "Análise e Síntese" é:

( )Muito Relevante ( )Relevante ( )Indiferente( )Pouco Relevante ( )Irrelevante Pontos relevantes em relação a fase de "Análise e Síntese":

3 Descoberta do Consumidor: consiste em transformar a visão estabelecida para a solução na fase de "Análise e Síntese" numa série de hipóteses que serão testadas para verificação das reações dos consumidores e validação do seu real interesse.

Na sua opinião a etapa de "Descoberta do Consumidor" é:

( )Muito Relevante ( )Relevante ( )Indiferente( )Pouco Relevante ( )Irrelevante Pontos relevantes em relação a fase de "Descoberta do Consumidor":

\section{Conversão}

$\mathrm{Na}$ fase de Conversão ocorre a transformação dos conhecimentos estruturados anteriormente em resultados inovadores efetivos (produtos, serviços e processos). Inclui as etapas de "Ideação", geração de alternativas de produtos e serviços do Design Thinking e "Produto Mínimo Viável", estruturação de protótipos contemplando apenas as funções identificadas como críticas do produto ou serviço e "Validação do 
Consumidor", teste deste produto mínimo viável junto a potencias clientes do Lean Startup. Os resultados esperados no final desta incluem, além dos "Produtos Mínimos Viáveis", a matriz de posicionamento da organização, que irá permitir o desenho do plano de negócios que será testado junto aos consumidores que validarão a proposta visando a sua continuidade. Caso a proposta não seja validada deve-se retornar à etapa anterior (Geração de Ideias).

Na sua opinião o processo de Conversão, ou seja, transformação dos conhecimentos estruturados em resultados inovadores é composta apenas e necessariamente pelas etapas de Ideação, Mínimo Produto Viável e Validação do Consumidor?

( ) Sim ( )Não

Se não, quais etapas estão a mais? Sentiu falta de outras etapas?

4 Ideação: busca a geração e refinamento das primeiras ideias, permitindo o teste das ideias aplicando técnicas como brainstorming, cardápio de ideias, matriz de posicionamento, etc.

Na sua opinião a etapa de "Ideação" é:

( )Muito Relevante ( )Relevante ( )Indiferente( )Pouco Relevante ( )Irrelevante Pontos relevantes em relação a fase de "Ideação":

5.1 Produto Mínimo Viável:construção de protótipo de baixa ou alta fidelidade e que incorpora as principais funções definidas como relevantes pela startup, de forma a permitir um primeiro teste das hipóteses elaboradas pelo empreendedor até 0 momento.

Na sua opinião a etapa de "Produto Mínimo Viável" é:

( )Muito Relevante ( )Relevante ( )Indiferente( )Pouco Relevante ( )Irrelevante Pontos relevantes em relação a fase de "Produto Mínimo Viável":

5.2 Business Model Canvas:plano de negócios dinâmico que envolve de forma macro as etapas de: Segmentos de Consumo, Proposição de Valor, Canais, Relação com o Consumidor, Fontes de Receitas, Recursos Chave, Atividades Chave, Parcerias Chave e Estrutura de Custos.

Na sua opinião a etapa de "Business Model Canvas" é:

( )Muito Relevante ( )Relevante ( )Indiferente( )Pouco Relevante ( )Irrelevante Pontos relevantes em relação a fase de "Business Model Canvas": 
Na sua opinião a etapa de "Produto Mínimo Viável" em conjunto com o "Business Model Canvas" é:

( )Muito Relevante ( )Relevante ( )Indiferente( )Pouco Relevante ( )Irrelevante Pontos relevantes em relação a fase de "Produto Mínimo Viável" em conjunto com o "Business Model Canvas":

6 Validação do Consumidor: busca aprender mais sobre o público de interesse e para isto apresenta o Produto Mínimo Viável e realiza testes de aceitação junto aos consumidores potenciais.

Na sua opinião a etapa de "Validação do Consumidor" é:

( )Muito Relevante ( )Relevante ( )Indiferente( )Pouco Relevante ( )Irrelevante Pontos relevantes em relação a fase de "Validação do Consumidor":

\section{Difusão}

$\mathrm{Na}$ etapa de Difusão os conceitos originais que resultaram nas inovações são efetivamente "comprados" pelos consumidores e pelos membros da organização, sendo caracterizada pela comercialização inicial do produto, serviço ou processo e eventualmente demandando a elaboração de um novo plano de negócios. Neste momento o desenvolvimento e o aprendizado devem ser compartilhados para a conclusão das etapas e das fases do framework. Este estágio é caracterizado pela exploração da inovação que beneficia organização com o aumento da produtividade do negócio e da rentabilidade de seus produtos e serviços. Esta fase inclui as etapas de "Prototipação", consolidação dos conceitos imaginados em produtos ou serviços capazes de serem avaliados pelo consumidor e "Implementação", início das operações da startup, do Design Thinking, além das etapas de "Criação do Consumidor", realização das primeiras vendas, e "Construção da Organização", escalonamento da organização de acordo com os resultados obtidos, ambos do Lean Startup.

Na sua opinião o processo de Difusão, primeira comercialização do produto, serviço ou processo, é composto apenas e necessariamente pelas etapas de Implementação, Prototipação, Criação do Consumidor e Construção da Organização?

( ) $\operatorname{Sim}($ )Não

Se não, quais etapas estão a mais? Sentiu falta de outras etapas? 
7 Implementação: tem como foco viabilizar o estabelecimento das operações da startup, incluindo a finalização dos seus produtos e serviços e início das transações com os segmentos de clientes de interesse.

Na sua opinião a etapa de "Implementação" é:

( )Muito Relevante ( )Relevante ( )Indiferente( )Pouco Relevante ( )Irrelevante Pontos relevantes em relação a fase de "Implementação":

8.1 Prototipação: com base nos resultados obtidos com os testes do Produto Mínimo Viável esta etapa tem por objetivo viabilizar uma primeira versão comercial do produto e/ou serviço que será oferecido ao mercado.

Na sua opinião a etapa de "Prototipação" é:

( )Muito Relevante ( )Relevante ( )Indiferente( )Pouco Relevante ( )Irrelevante Pontos relevantes em relação a fase de "Prototipação":

8.2 Business Model Canvas:plano de negócios dinâmico que envolve de forma macro as etapas de: Segmentos de Consumo, Proposição de Valor, Canais, Relação com o Consumidor, Fontes de Receitas, Recursos Chave, Atividades Chave, Parcerias Chave e Estrutura de Custos.

Na sua opinião a etapa de "Prototipação" em conjunto com o"Business Model Canvas" é:

( )Muito Relevante ( )Relevante ( )Indiferente( )Pouco Relevante ( )Irrelevante Pontos relevantes em relação a fase de "Prototipação" em conjunto com o "Business Model Canvas" é:

9 Criação do Consumidor: tem como foco realizar as primeiras vendas efetivas do produto e/ou serviço, confirmando se a proposta de valor efetivamente resolve a questão do consumidor.

Na sua opinião a etapa de "Criação do Consumidor" é:

( )Muito Relevante ( )Relevante ( )Indiferente( )Pouco Relevante ( )Irrelevante Pontos relevantes em relação a fase de "Criação do Consumidor":

10.1 Construção da Organização: busca estabelecer todos os demais aspectos para operacionalização da startup, incluindo a aquisição dos recursos principais, desenvolvimento de parcerias e estabelecimento das atividades produtivas. 
Na sua opinião a etapa de "Construção da Organização" é:

( )Muito Relevante ( )Relevante ( )Indiferente( )Pouco Relevante ( )Irrelevante Pontos relevantes em relação a fase de "Construção da Organização":

10.2 Business Model Canvas: plano de negócios dinâmico que envolve de forma macro as etapas de: Segmentos de Consumo, Proposição de Valor, Canais, Relação com o Consumidor, Fontes de Receitas, Recursos Chave, Atividades Chave, Parcerias Chave e Estrutura de Custos.

Na sua opinião a etapa de "Construção da Organização" em conjunto com o "Business Model Canvas" é:

( )Muito Relevante ( )Relevante ( )Indiferente( )Pouco Relevante ( )Irrelevante Pontos relevantes em relação a fase de "Construção da Organização" em conjunto com o "Business Model Canvas": 


\section{ANEXO 3 - Questionário dos Empreendedores de Startups}

Prezado Empreendedor(a),

Consegui o contato da organização por meio da aceleradora, meu nome é Diane dos Reis Farina, sou estudante do Programa de Pós Graduação em Engenharia de Produção da Universidade de São Paulo e estou construindo um "framework para estruturação de startups", que combina conceitos de diferentes teorias incluindo Cadeia de Valor da Inovação, Design Thinking, Business Model Canvas e Lean Startup.

Nossa amostragem para validação deste modelo inclui startups brasileiras que estejam em fase de aceleração ou que tenham sido aceleradas em conceituadas aceleradoras. Em função disto a sua startup foi selecionada para participar da pesquisa. Esta participação consiste nos empreendedores de startups responderem com base em sua vivência um questionário que não terá duração de mais de 10 minutos e cujo link está abaixo.

Ao responder o questionário o empreendedor conhecerá um pouco mais sobre estas diferentes teorias que, acredito que quando aplicadas em conjunto, podem resultar em startups de grande sucesso e potencial de crescimento. Como forma de retribuir a contribuição tão importante irei fornecer os resultados finais da pesquisa aos respondentes, para tal, peço que não esqueça de preencher o e-mail em que deseja receber os resultados na questão 10 das Informações dos Respondentes.

Diane dos Reis, Programa de Pós Graduação em Engenharia de Produção da Universidade de São Paulo. Contatos: (11) 98503.2725 / diane.reis@hotmail.com. 


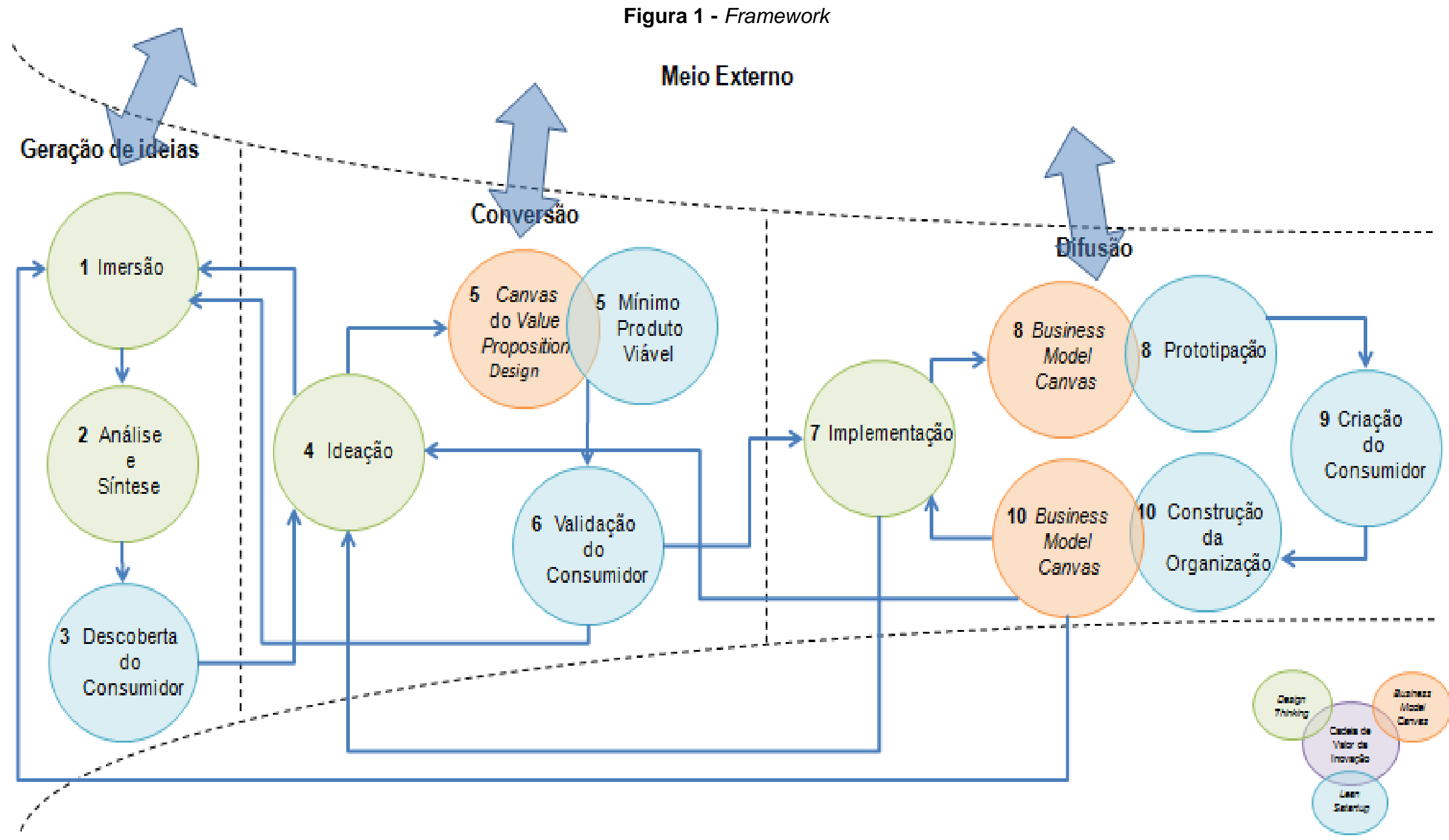

Fonte: Elaborado pela autora. 


\section{Informações do Respondente}

Todas estas informações serão usadas para classificação das respostas, os nomes não serão mencionados na pesquisa.O preenchimento é opcional.

1 Qual seu nome completo?

2 Qual sua idade?

3 Formação acadêmica?

$\begin{array}{lll}\text { ( ) Graduação } & \text { ( ) Pós-graduação } & \text { ( ) Mestrado } \\ \text { ( ) Doutorado } & \text { ( ) Pós-doutorado } & \text { ( ) Outros }\end{array}$

4 Gênero?

( ) Feminino ( ) Masculino

5 Quantidade de anos de atuação como empreendedor?

$6 \quad$ Já atuou com quantas startups?

7 Quantidade de anos de atuação com a startup atual?

8 Quantidade de anos da existência da startup em que atua no momento?

$9 \quad$ Nome da startup atual?

10 E-mail no qual deseja receber os resultados da pesquisa: 


\section{Geração de Ideias}

É o momento em que se inicia o desenvolvimento de algo novo, usualmente combinando diferentes ideias, aprimoradas com os conhecimentos trazidos pelas diferentes partes interessadas. As ideias podem ser geradas internamente pela organização e combinadas com ideias provenientes de fontes externas à empresa. Desta forma, os conhecimentos utilizados podem ser externos ou internos à organização.

Neste framework a fase de Geração de Ideias inclui as etapas de "Imersão", amplo levantamento de informações, e "Análise e Síntese", consolidação das informações previamente obtidas, ambos provenientes do Design Thinking, além da etapa de "Descoberta do Consumidor", que busca identificar os consumidores interessados pelas inovações em desenvolvimento, proveniente do Lean Startup. Como resultado desta fase espera-se 0 entendimento da situação a ser solucionada, a consolidação dos conhecimentos sobre o consumidor a quem se destina esta solução e a efetiva geração de ideias com foco nos consumidores.

1 Imersão: busca o entendimento do ambiente, do mercado e dos segmentos de clientes de interesse; usualmente inclui ampla pesquisa sobre estes tópicos, aplicando técnicas como benchmarks, levantamento da voz do cliente, pesquisas bibliográficas, entre outros.

Na sua trajetória de empreendedor a etapa de "Imersão" foi realizada:

( ) Em todos os projetos ( ) Na maioria dos projetos ( ) Em cerca de metade dos projetos

( ) Em poucos projetos ( ) Em nenhum projeto

Em função de sua trajetória como empreendedor, recomenda a etapa de "Imersão":

( ) Sim ( ) Não

Pontos relevantes em relação a fase de "Imersão":

2 Análise e Síntese: consolida as informações obtidas na Imersão e busca estabelecer padrões e conexões entre estas utilizando de técnicas como personas, mapa de empatia e jornada do usuário.

Na sua trajetória de empreendedor a etapa de "Análise e Síntese" foi realizada:

( ) Em todos os projetos ( ) Na maioria dos projetos ( ) Em cerca de metade dos projetos

( ) Em poucos projetos ( ) Em nenhum projeto 
Em função de sua trajetória como empreendedor, recomenda a etapa de "Análise e Síntese":

( ) Sim ( ) Não

Pontos relevantes em relação a fase de "Análise e Síntese":

3 Descoberta do Consumidor: consiste em transformar a visão estabelecida para a solução na fase de "Análise e Síntese" numa série de hipóteses que serão testadas para verificação das reações dos consumidores e validação do seu real interesse.

Na sua trajetória de empreendedor a etapa de "Descoberta do Consumidor" foi realizada:

( ) Em todos os projetos ( ) Na maioria dos projetos ( ) Em cerca de metade dos projetos

( ) Em poucos projetos ( ) Em nenhum projeto

Em função de sua trajetória como empreendedor, recomenda a etapa de "Descoberta do Consumidor":

( ) Sim ( ) Não

Pontos relevantes em relação a fase de "Descoberta do Consumidor":

\section{Conversão}

$\mathrm{Na}$ fase de Conversão ocorre a transformação dos conhecimentos estruturados anteriormente em resultados inovadores efetivos (produtos, serviços e processos). Inclui as etapas de "Ideação", geração de alternativas de produtos e serviços do Design Thinking e "Produto Mínimo Viável", estruturação de protótipos contemplando apenas as funções identificadas como críticas do produto ou serviço, em conjunto com o "Canvas do Value Proposition Design", este último proveniente de um complemento ao Business Model Canvas e "Validação do Consumidor", teste deste produto mínimo viável junto a potencias clientes do Lean Startup. Os resultados esperados no final desta incluem, além dos "Produtos Mínimos Viáveis", a matriz de posicionamento da organização, que irá permitir o desenho do plano de negócios que será testado junto aos consumidores que validarão a proposta visando a sua continuidade. Caso a proposta não seja validada deve-se retornar à etapa anterior (Geração de Ideias).

4 Ideação: busca a geração e refinamento das primeiras ideias, permitindo o teste das ideias aplicando técnicas como brainstorming, cardápio de ideias e matriz de posicionamento. 
Na sua trajetória de empreendedor a etapa de "Ideação" foi realizada:

( ) Em todos os projetos ( ) Na maioria dos projetos ( ) Em cerca de metade dos projetos

( ) Em poucos projetos ( ) Em nenhum projeto

Em função de sua trajetória como empreendedor, recomenda a etapa de "Ideação":

( ) Sim

( ) Não

Pontos relevantes em relação a fase de "Ideação":

5.1 Produto Mínimo Viável: construção de protótipo de baixa ou alta fidelidade e que incorpora as principais funções definidas como relevantes pela startup, de forma a permitir um primeiro teste das hipóteses elaboradas pelo empreendedor até o momento.

Na sua trajetória de empreendedor a etapa de "Produto Mínimo Viável" foi realizada:

( ) Em todos os projetos ( ) Na maioria dos projetos ( ) Em cerca de metade dos projetos

( ) Em poucos projetos ( ) Em nenhum projeto

Em função de sua trajetória como empreendedor, recomenda a etapa de "Produto Mínimo Viável":
( ) Sim
( ) Não

Pontos relevantes em relação a fase de "Produto Mínimo Viável":

5.2 Canvas do Value Proposition Design: busca identificar as principais necessidades, sentimentos e desejos do consumidor e alinhar a criação de valor para o mesmo por meio da identificação das características, benefícios, e experiências que serão viabilizadas pelo produto e/ou serviço.

Na sua trajetória de empreendedor a etapa de "Canvas do Value Proposition Design" foi realizada:

( ) Em todos os projetos ( ) Na maioria dos projetos ( ) Em cerca de metade dos projetos

( ) Em poucos projetos ( ) Em nenhum projeto

Em função de sua trajetória como empreendedor, recomenda a etapa de "Canvas do Value Proposition Design":

( ) Sim ( ) Não

Pontos relevantes em relação a fase de "Canvas do Value Proposition Design": 
Na sua trajetória de empreendedor a etapa de "Produto Mínimo Viável" em conjunto com o "Canvas do Value Proposition Design" foi realizada:

( ) Em todos os projetos ( ) Na maioria dos projetos ( ) Em cerca de metade dos projetos

( ) Em poucos projetos ( ) Em nenhum projeto

Em função de sua trajetória como empreendedor, recomenda a etapa de "Canvas do Value Proposition Design" em conjunto com o "Produto Mínimo Viável":

( ) Sim

( ) Não

Pontos relevantes em relação a fase de "Produto Mínimo Viável" em conjunto com o"Canvas do Value Proposition Design":

6 Validação do Consumidor: busca aprender mais sobre o público de interesse e para isto apresenta o Produto Mínimo Viável e realiza testes de aceitação junto aos consumidores potenciais.

Na sua trajetória de empreendedor a etapa de "Validação do Consumidor" foi realizada:

( ) Em todos os projetos ( ) Na maioria dos projetos ( ) Em cerca de metade dos projetos

( ) Em poucos projetos ( ) Em nenhum projeto

Em função de sua trajetória como empreendedor, recomenda a etapa de "Validação do Consumidor":

( ) Sim ( ) Não

Pontos relevantes em relação a fase de "Validação do Consumidor":

\section{Difusão}

$\mathrm{Na}$ etapa de Difusão os conceitos originais que resultaram nas inovações são efetivamente "comprados" pelos consumidores e pelos membros da organização, sendo caracterizada pela comercialização inicial do produto, serviço ou processo e eventualmente demandando a elaboração de um novo plano de negócios. Neste momento o desenvolvimento e o aprendizado devem ser compartilhados para a conclusão das etapas e das fases do framework. Este estágio é caracterizado pela exploração da inovação que beneficia organização com o aumento da produtividade do negócio e da rentabilidade de seus produtos e serviços. Esta fase inclui as etapas de "Prototipação", consolidação dos conceitos imaginados em produtos ou serviços capazes de serem avaliados pelo consumidor e "Implementação", início das operações da startup, do Design Thinking, além das etapas de "Criação do Consumidor", realização das primeiras vendas, e "Construção da 
Organização", escalonamento da organização de acordo com os resultados obtidos, ambos do Lean Startup.

7 Implementação: tem como foco viabilizar o estabelecimento das operações da startup, incluindo a finalização dos seus produtos e serviços e início das transações com os segmentos de clientes de interesse.

Na sua trajetória de empreendedor a etapa de "Implementação" foi realizada:

( ) Em todos os projetos ( ) Na maioria dos projetos ( ) Em cerca de metade dos projetos

( ) Em poucos projetos ( ) Em nenhum projeto

Em função de sua trajetória como empreendedor, recomenda a etapa de "Implementação":

( ) Sim ( ) Não

Pontos relevantes em relação a fase de "Implementação":

8.1 Prototipação: com base nos resultados obtidos com os testes do Produto Mínimo Viável esta etapa tem por objetivo viabilizar uma primeira versão comercial do produto e/ou serviço que será oferecido ao mercado.

Na sua trajetória de empreendedor a etapa de "Prototipação" foi realizada:

( ) Em todos os projetos ( ) Na maioria dos projetos ( ) Em cerca de metade dos projetos

( ) Em poucos projetos ( ) Em nenhum projeto

Em função de sua trajetória como empreendedor, recomenda a etapa de "Prototipação":

( ) Sim ( ) Não

Pontos relevantes em relação a fase de "Prototipação":

8.2 Business Model Canvas: plano de negócios dinâmico que envolve de forma macro as etapas de: Segmentos de Consumo, Proposição de Valor, Canais, Relação com o Consumidor, Fontes de Receitas, Recursos Chave, Atividades Chave, Parcerias Chave e Estrutura de Custos.

Na sua trajetória de empreendedor a etapa de "Business Model Canvas" foi realizada:

( ) Em todos os projetos ( ) Na maioria dos projetos ( ) Em cerca de metade dos projetos

( ) Em poucos projetos ( ) Em nenhum projeto

Em função de sua trajetória como empreendedor, recomenda a etapa de "Business Model Canvas":

( ) Sim

( ) Não 
Pontos relevantes em relação a fase de "Business Model Canvas":

Na sua trajetória de empreendedor a etapa de "Prototipação" em conjunto com o"Business Model Canvas" foi realizada:

( ) Em todos os projetos ( ) Na maioria dos projetos ( ) Em cerca de metade dos projetos

( ) Em poucos projetos ( ) Em nenhum projeto

Em função de sua trajetória como empreendedor, recomenda a etapa de "Business Model Canvas" em conjunto com a "Prototipação":
( ) Sim
( ) Não

Pontos relevantes em relação a fase de "Prototipação" em conjunto com o "Business Model Canvas":

9 Criação do Consumidor: tem como foco realizar as primeiras vendas efetivas do produto e/ou serviço, confirmando se a proposta de valor efetivamente resolve a questão do consumidor.

Na sua trajetória de empreendedor a etapa de "Criação do Consumidor" foi realizada:

( ) Em todos os projetos ( ) Na maioria dos projetos ( ) Em cerca de metade dos projetos

( ) Em poucos projetos ( ) Em nenhum projeto

Em função de sua trajetória como empreendedor, recomenda a etapa de "Criação do Consumidor":

( ) Sim ( ) Não

Pontos relevantes em relação a fase de "Criação do Consumidor":

10.1 Construção da Organização:busca estabelecer todos os demais aspectos para operacionalização da startup, incluindo a aquisição dos recursos principais, desenvolvimento de parcerias e estabelecimento das atividades produtivas.

Na sua trajetória de empreendedor a etapa de "Construção da Organização" foi realizada:

( ) Em todos os projetos ( ) Na maioria dos projetos ( ) Em cerca de metade dos projetos

( ) Em poucos projetos ( ) Em nenhum projeto

Em função de sua trajetória como empreendedor, recomenda a etapa de "Construção da Organização":
( ) Sim
( ) Não 
Pontos relevantes em relação a fase de "Construção da Organização":

10.2 Business Model Canvas: plano de negócios dinâmico que envolve de forma macro as etapas de: Segmentos de Consumo, Proposição de Valor, Canais, Relação com o Consumidor, Fontes de Receitas, Recursos Chave, Atividades Chave, Parcerias Chave e Estrutura de Custos.

Na sua trajetória de empreendedor a etapa de "Construção da Organização" em conjunto com o "Business Model Canvas" foi realizada:

( ) Em todos os projetos ( ) Na maioria dos projetos ( ) Em cerca de metade dos projetos

( ) Em poucos projetos ( ) Em nenhum projeto

Em função de sua trajetória como empreendedor, recomenda a etapa de "Business Model Canvas" em conjunto com a "Construção da Organização":

( ) Sim ( ) Não

Pontos relevantes em relação a fase de "Business Model Canvas" em conjunto com o "Construção da Organização": 